CLÁUDIO ANTONIO ROSSI

\title{
ANÁLISE DE ESTRATÉGIAS DE HEDGING ESTÁTICAS APLICADAS A COMMODITIES AGRÍCOLAS
}

Dissertação apresentada à Escola

Politécnica da Universidade de São Paulo para obtenção do título de Mestre em Engenharia 
CLÁUDIO ANTONIO ROSSI

\section{ANÁLISE DE ESTRATÉGIAS DE HEDGING ESTÁTICAS APLICADAS A COMMODITIES AGRÍCOLAS}

Dissertação apresentada à Escola Politécnica da Universidade de São Paulo para obtenção do título de Mestre em Engenharia

Área de Concentração: Engenharia da Produção - Economia da Produção e Engenharia Financeira

Orientador (a): Profa. Dra. Celma de Oliveira Ribeiro 


\section{FICHA CATALOGRÁFICA}

\section{Rossi, Cláudio Antonio}

Análise de estratégias de heding estáticas aplicadas a commodities agrícolas / C.A.Rossi. -- São Paulo, 2008.

$151 \mathrm{p}$.

Dissertação (Mestrado) - Escola Politécnica da Universidade de São Paulo. Departamento de Engenharia de Produção.

1. Administração de risco 2. Finanças agrícolas 3. Produção agrícola 4. Estratégias de hedging estáticas 5.Contratos futuros I.Universidade de São Paulo. Escola Politécnica. Departamento de Engenharia de Produção Il.t. 


\section{DEDICATÓRIA}

Dedico este trabalho aos meus pais Mario e Hercília, à minha irmã Renata e à minha esposa Samira. 


\section{AGRADECIMENTOS}

Agradeço primeiramente a Deus por ter me concedido a vida, a virtude da determinação e a capacidade para alcançar meus objetivos.

Agradeço ao meu pai Mario e a minha mãe Hercília que, mesmo distantes, sempre me apoiaram nos momentos difíceis e, antecipadamente, me presentearam com a maior herança que se pode deixar para um filho: a educação e a ética; as quais me permitiram sempre seguir corretamente meus caminhos. Da mesma forma, minha irmã Renata, que também distante, sempre me aconselhou e incentivou a concluir este trabalho.

Agradeço especialmente à minha esposa Samira, sem a qual a conclusão deste trabalho seria muito mais árdua. Uma pessoa muito especial, que sempre soube entender os momentos de ausência; cuja capacidade e facilidade em enxergar a solução dos problemas foram muito importantes, além de sempre me ouvir, apoiar e aconselhar nos momentos difíceis.

Agradeço à minha orientadora profa. Dra. Celma Oliveira Ribeiro pela dedicação e disponibilidade para me dar as diretrizes corretas, fundamentais, para a conclusão deste trabalho.

Agradeço aos diretores e amigos da Joule Asset Management, Roberto Pinter le e José Luiz Junqueira, por permitirem a flexibilidade do horário de trabalho e até ausência no mesmo, de modo que foi fundamental para a realização dessa dissertação. Agradeço, especialmente, ao José Luiz Junqueira pela disponibilidade e ajuda no desenvolvimento da programação em VBA, que viabilizou a execução do trabalho com maior acurácia e rapidez.

Agradeço à profa. Cimara Pereira Prada pela revisão e correções referente à língua portuguesa e também a ajuda da profa. Dra. Alessandra Montini Ventura.

Agradeço ao amigo Thadeu Theodoro, sempre disposto a ajudar e também pela disponibilidade de revisar algumas partes deste trabalho. 


\section{RESUMO}

Dentre as diversas ferramentas disponíveis para gestão de risco no mercado financeiro, este trabalho analisa estratégias de hedging para commodities agrícolas, utilizando o mercado futuro. Isto posto, efetua-se uma revisão das diferentes estratégias apresentadas pela literatura e analisa-se sua aplicação para o mercado brasileiro. Ao construir uma estratégia de hedging no mercado futuro, busca-se determinar o número de contratos a ser adquirido ou vendido, de forma a reduzir o risco financeiro, resultante de oscilações adversas no preço dos ativos. Ou seja, considerando-se um portfólio composto por dois ativos, um no mercado à vista e outro no futuro, as diferentes medidas de desempenho - caracterizadas pelas diversas estratégias - conduzem a diferentes portfólios ótimos. Dessa forma, pretende-se analisar qual a melhor estratégia, determinando, implicitamente, qual a composição de portfolio mais adequada a um agente específico no mercado de commodities. São analisados o mercado do café, da soja, do açúcar e do álcool. Ativos financeiros, como o câmbio e o lbovespa, também são considerados, a fim de averiguar eventuais diferenças de comportamento das estratégias, resultantes de peculiaridades do mercado de commodities. As estratégias estudadas foram: de mínima variância; de mínima variância condicionada ao período de carregamento, de maximização do índice de Sharpe; de maximização da utilidade esperada; de minimização do coeficiente de Gini estendido; de regressão linear; de regressão linear condicionada ao conjunto de informações e regressão linear condicinada ao conjunto de informações e ao período de carregamento. Apesar de o trabalho considerar somente estratégias estáticas, que se caracterizam por, uma vez determinado a quantidade de contratos a se posicionar no mercado futuro, não mais se alterar até o vencimento dos mesmos, adotou-se uma abordagem dinâmica para análise, presumindo que o portfólio pudesse ser reestruturado ao longo do tempo, de acordo com o comportamento do mercado, permitindo empregar uma abordagem mais próxima da realidade. Os resultados indicaram que as estratégias possuem diferenças, derivadas de sua estrutura, mas não variaram significativamente em função do tipo de commodity analisada. Não foi possível também identificar uma estratégia que fosse superior às demais, ou mais adequada, para uma commodity específica, do ponto de vista de resultado financeiro. Os resultados sugerem entretanto, que a seleção de uma estratégia por parte do investidor, deverá considerar as tendências de mercado, abrindo espaço para a incorporação desta informação nos modelos empregados.

Palavras-chave: cadeia produtiva agrícola; gestão de risco financeiro; estratégias de hedging estáticas; mercado futuro 


\section{ABSTRACT}

Among the various tools available for managing risk in the financial market, this research analyzes hedging strategies for agricultural commodities, using the future market. It given makes up a review of different strategies presented by the literature and looks to its application to the Brazilian market. By constructing a strategy of hedging in the future market, seeks to determine the number of contracts to be purchased or sold, in order to reduce the financial risk, resulting from adverse fluctuations in the price of assets. In other words, considering a portfolio consisting of two assets, one in the spot market and one in the future, the various measures of performance - characterized by different strategies - leading to different portfolios optimum. Thus, it is intended to examine the best strategy, determining, implicitly, what the composition of portfolio best suited to a specific agent on the market of commodities. The markets analyzed were the coffee market, soybean market, sugar and alcohol market. Financial assets, such as exchange and the lbovespa Index, are also considered in order to ascertain any differences in behavior of strategies, from peculiarities of the commodities market. The strategies studied were: the minimumvariance, the minimum-variance on the time lifted, the maximum Sharpe index; the maximum expected utility, the minimum extended Gini coefficient; the regression method; the regression method conditional on the set of information, and regression method conditional on the set of information and the time lifted. Although this research considered only static strategies which have since determined the amount of contracts to position itself in the future market, no more changes until the expiration of them, took up a dynamic approach for analysis, assuming that the portfolio could be restructured over time, according to the behavior of the market and will allow an approach closer to reality. The results indicated that strategies have differences, derived from its structure, but did not vary significantly depending on the type of commodity examined. Unable also identify a strategy with superiority than other, or more appropriately, for a specific commodity, from the viewpoint of financial results. The results suggest, however that the selection of a strategy by the investor should consider the trends of the market, opening up space to incorporate this information into the model employed.

Key-words: agricultural production chain; managing financial risk; static hedging strategies; future market 


\section{LISTA DE ILUSTRAÇÕES}

FIgURA 1 - MODELO DE AGRONEGÓCIO

Figura 2 - Modelo Geral da Cadeia Produtiva, Segundo metodologia dA EMBRAPA.

FIGURA 3 - GRÁFICOS BOX-PLOT E MEDIANAS DAS MEDIDAS DE EFICÁCIA PARA O ATIVO AÇÚCAR CRISTAL

FIGURA 4 - GRÁFICOS BOX-PLOT E MEDIANAS DAS MEDIDAS DE EFICÁCIA PARA O ÁLCOOL ANIDRO

FIGURA 5 - GRÁFICOS BOX-PLOT E MEDIANAS DAS MEDIDAS DE EFICÁCIA PARA O CAFÉ ARÁBICA... 122

FIGURA 6 - GRÁFICOS BOX-PLOT E MEDIANAS DAS MEDIDAS DE EFICÁCIA PARA A SOJA ....124

FIGURA 7 - GRÁFICOS BOX-PLOT E MEDIANAS DAS MEDIDAS DE EFICÁCIA PARA O DÓLAR COMERCIAL 126

FIGURA 8 - GRÁFICOS BOX-PLOT E MEDIANAS DAS MEDIDAS DE EFICÁCIA PARA O IBOVESPA 


\section{LISTRA DE GRÁFICOS}

GRÁFICO 1 - PRODUTORES DE AÇÚCAR COM MENORES CUSTOS NO MUNDO.

GRÁFICO 2 - PROPORÇÃO DE CONTRATOS AGRÍCOLAS NEGOCIADOS ANUALMENTE ENTRE

2000 E 2007 - POR PRODUTO 45

GRÁFICO 3 - EXPORTAÇÃO ANUAL POR PRODUTO AGROPECUÁRIO ENTRE 2000 E $2007 \ldots . . .48$

GRÁFICO 4 - REPRESENTAÇÃO GRÁFICA DA FRONTEIRA EFICIENTE E REGIÃO VIÁVEL. .57

GRÁFICO 5 - SÉRIE DE PREÇOS À VISTA E FUTURO DO AÇÚCAR CRISTAL 102

GRÁFICO 6 - SÉRIE DE PREÇOS À VISTA E FUTURO DO ÁLCOOL ANIDRO. 104

GRÁFICO 7 - SÉRIE DE PREÇOS À VISTA E FUTURO PARA O CAFÉ ARÁBICA . 106

GRÁFICO 8 - SÉRIE DE PREÇOS À VISTA E FUTURO PARA A SOJA. 108

GRÁFICO 9 - SÉRIE DE PREÇOS À VISTA E FUTURO PARA O DÓLAR COMERCIAL ENCADEADOS POR CONTRATO

GRÁFICO 10 - SÉRIE DE PREÇOS À VISTA E FUTURO PARA O IBOVESPA ENCADEADOS POR CONTRATO

GRÁFICO 11 - EVOLUÇÃO DAS MEDIDAS DE EFICÁCIA POR ESTRATÉGIA PARA O AÇÚCAR CRISTAL

GRÁFICO 12 - EVOLUÇÃO DAS MEDIDAS DE EFICÁCIA POR ESTRATÉGIA PARA O ÁLCOOL ANIDRO

GRÁFICO 13 - EVOLUÇÃO DAS MEDIDAS DE EFICÁCIA POR ESTRATÉGIA PARA O CAFÉ ARÁBICA 121

GRÁFICO 14 - EVOLUÇÃO DAS MEDIDAS DE EFICÁCIA POR ESTRATÉGIA PARA A SOJA 123

GRÁFICO 15 - EVOLUÇÃO DAS MEDIDAS DE EFICÁCIA POR ESTRATÉGIA PARA O DÓLAR COMERCIAL 125

GRÁFICO 16 - EVOLUÇÃO DAS MEDIDAS DE EFICÁCIA POR ESTRATÉGIA PARA O IBOVESPA 127 GRÁFICO 17 - REPRESENTAÇÃO GRÁFICA DE DOMINÂNCIA ESTOCÁSTICA. 


\section{LISTA DE TABELAS}

TABELA 1 - MAIORES PAÍSES PRODUTORES E EXPORTADORES DE AÇÚCAR NO MUNDO .......40

TABela 2 - PRodução Mundial de CAFÉ POR PAís (VOlUme EM MIL SACAS DE 60 KG) ....43

TABELA 3 - PRINCIPAIS PAÍSES PRODUTORES DE SOJA DO MUNDO (VOLUME EM 1.000

TONELADAS)

TABELA 4 - PRINCIPAIS PAÍSES EXPORTADORES DE SOJA NO MUNDO (VOLUME EM 1.000

TONELADAS) 46

TABELA 5 - NÚMERO DE REGISTROS POR CONTRATO PARA CADA ATIVO 96

TABELA 6 - NOMENCLATURA DAS ESTRATÉGIAS 99

TABELA 7 - RESULTADOS FINANCEIROS POR VENCIMENTO PARA O AÇÚCAR CRISTAL

(VALORES EM R\$) 101

TABELA 8 - ANÁLISE DE VARIÂNCIA DE UM FATOR PARA O AÇÚCAR CRISTAL 102

TABELA 9 - RESULTADOS FINANCEIROS POR VENCIMENTO PARA O ÁLCOOL ANIDRO (VALORES EM R \$) 103

TABELA 10 - ANÁLISE DE VARIÂNCIA DE UM FATOR PARA O ÁLCOOL ANIDRO 104

TABELA 11 - RESULTADOS FINANCEIROS POR VENCIMENTO DO CAFÉ ARÁBICA (VALORES EM

$\mathrm{R} \$)$ 105

TABELA 12 - ANÁLISE DE VARIÂNCIA DE UM FATOR PARA O CAFÉ ARÁBICA 106

TABELA 13 - RESUltAdOS FINANCEIROS POR VENCIMENTO DA SOJA (VALORES EM R\$) ...107

TABELA 14 - ANÁLISE DE VARIÂNCIA DE UM FATOR PARA A SOJA. 108

TABELA 15 - RESULTADOS FINANCEIROS POR VENCIMENTO DO DÓLAR COMERCIAL (VALORES EM R $\$$ ) 109

TABELA 16 - ANÁLISE DE VARIÂNCIA DE UM FATOR PARA O DÓLAR COMERCIAL 110

TABELA 17 - RESULTADOS FINANCEIROS POR VENCIMENTO DO IBOVESPA (VALORES EM R\$)

TABELA 18 - ANÁLISE DE VARIÂNCIA DE UM FATOR PARA O IBOVESPA 112

TABELA 19 - ANÁLISE DE VARIÂNCIA PARA A ESTRATÉGIA 1 113

TABELA 20 - ANÁLISE DE VARIÂNCIA PARA A ESTRATÉGIA 2 113

TABELA 21 - ANÁLISE DE VARIÂNCIA PARA A ESTRATÉGIA 3 114

TABELA 22 - ANÁLISE DE VARIÂNCIA PARA A ESTRATÉGIA 4 114

TABELA 23 - ANÁLISE DE VARIÂNCIA PARA A ESTRATÉGIA 5 115

TABELA 24 - ANÁLISE DE VARIÂNCIA PARA A ESTRATÉGIA 6 115 
TABELA 25 - ANÁLISE DE VARIÂNCIA PARA A ESTRATÉGIA 7 115

TABELA 26 - ANÁLISE DE VARIÂNCIA PARA A ESTRATÉGIA 8 116

TABELA 27 - NOMENCLATURA PARA OS TESTES ESTATÍSTICOS COM O MULTIPLICADOR DE LAGRANGE 148

TABELA 28 - PROPORÇÃO DE CONJUNTO dE DADOS CONSIDERADOS SEGUIR UMA

DISTRIBUIÇÃO NORMAL 148

TABELA 29 - RESULTADOS DA ESTATíSTICA DE LAGRANGE PARA O AÇÚCAR CRISTAL 149

TABELA 30 - RESULTADOS DA ESTATÍSTICA DE LAGRANGE PARA ÁLCOOL ANIDRO. 149

TABELA 31 - RESULTADOS DA ESTATÍSTICA DE LAGRANGE PARA O CAFÉ ARÁBICA 150

TABELA 32 - RESULTADOS DA ESTATÍSTICA DE LAGRANGE PARA A SOJA 150

TABELA 33 - RESULTADOS DA ESTATÍSTICA DE LAGRANGE PARA O DÓLAR COMERCIAL.....151

TABELA 34 - REsultados dA ESTATÍSTICA DE LAGRANGE PARA O IBOVESPA. 151 


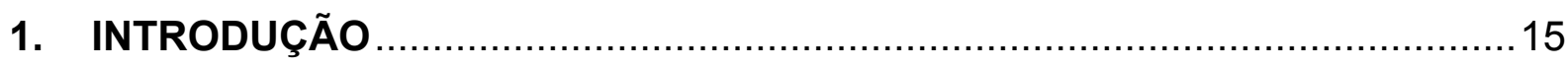

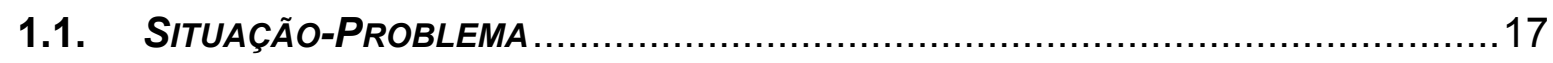

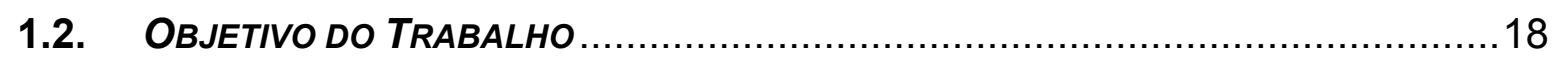

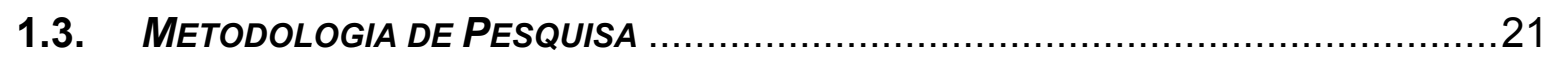

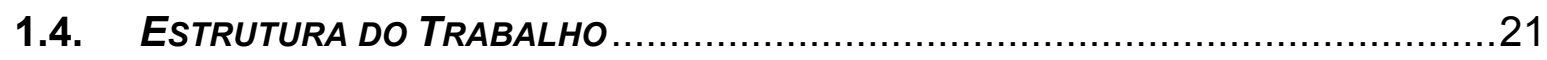

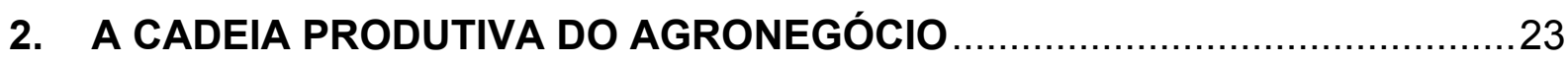

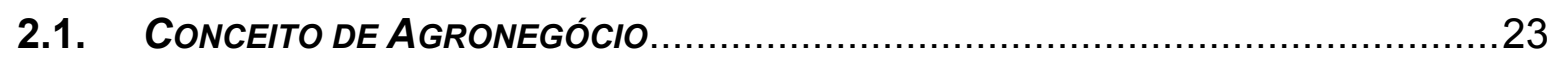

2.2. Conceito de Cadeia Produtiva

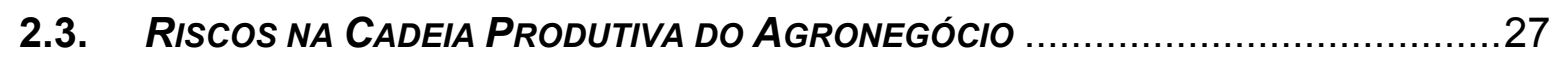

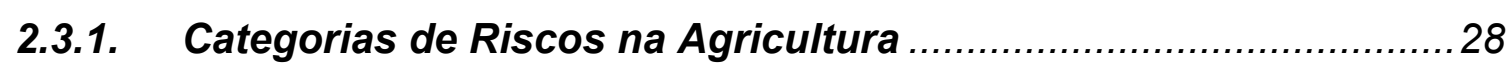

2.3.2. Percepção de Riscos pelos Produtores Agrícolas ........................29

2.4. MERCADOS E INFLUÊNCIAS SOBRE A FORMAÇÃO DE PREÇOS..........................32

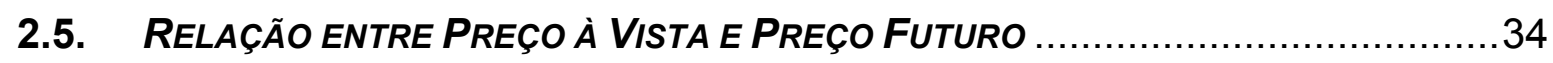

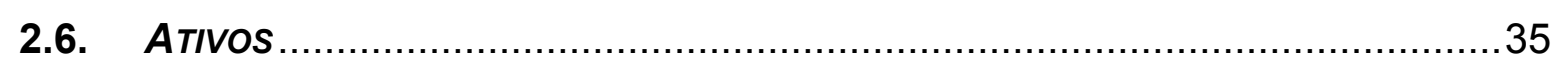

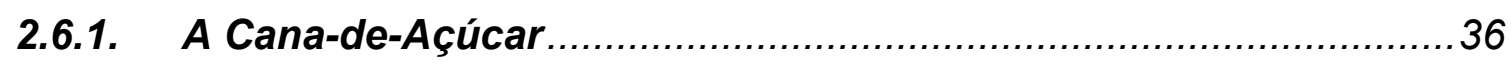

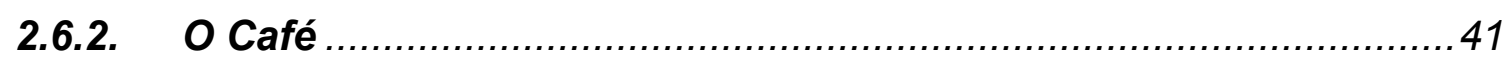

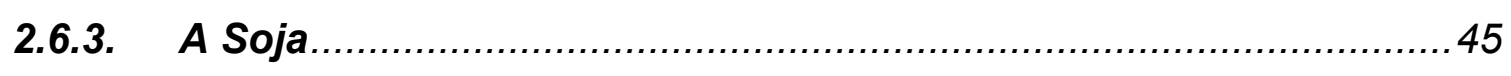

2.6.4. O Dólar Comercial e o lbovespa .................................................4 48

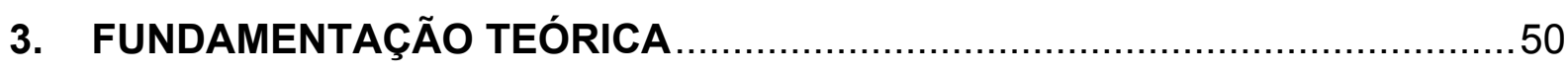

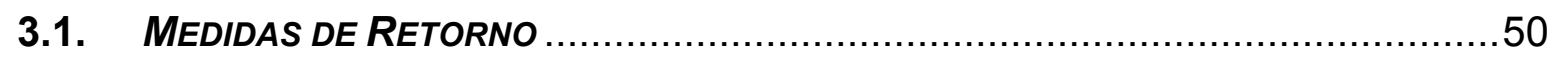

3.1.1. Retorno Discreto

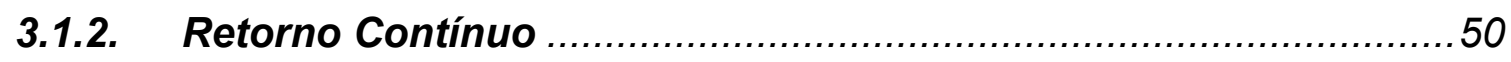

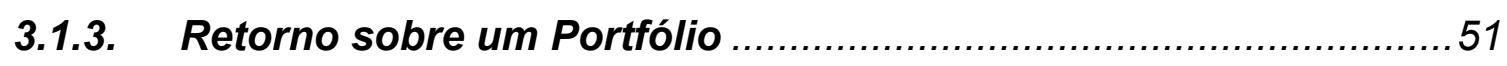

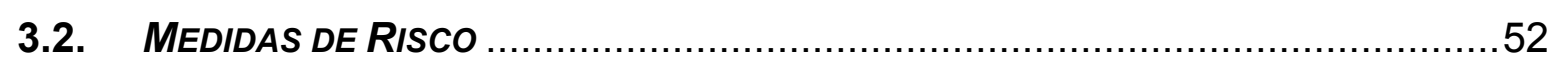

3.2.1. Variância dos Retornos sobre o Portfólio ...................................52

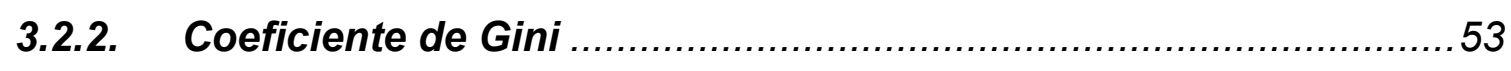

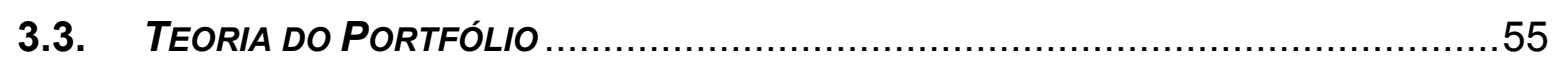

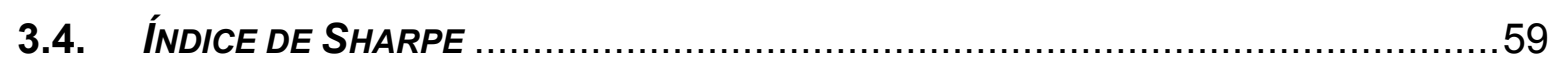

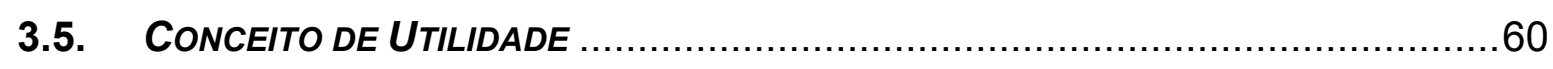

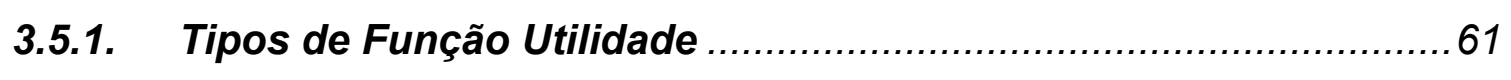




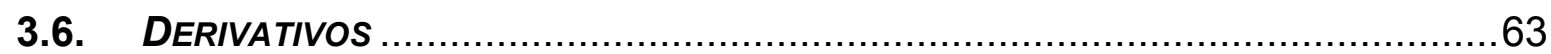

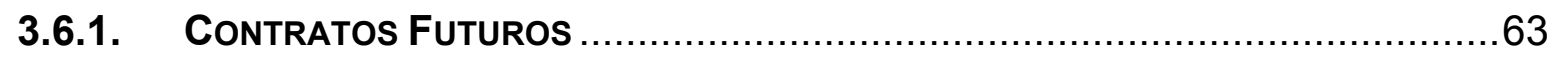

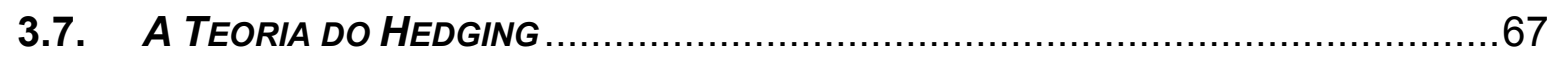

3.7.1. Conceito de Estratégia de Hedging com Mercado Futuro .............69

3.7.2. Retorno e Lucro do Portfólio Hedgeado .................................... 70

3.7.3. Variância dos Retornos e dos Lucros do Portfólio Hedgeado ......71

3.7.4. Eficácia da Estratégia de Hedging ............................................. 72

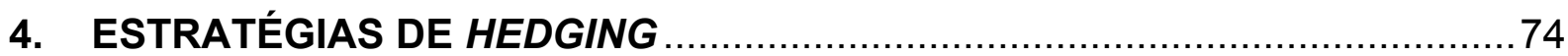

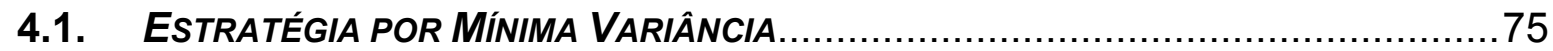

4.2. ESTRATÉGIA POR ANÁLISE DE REGRESSÃo LINEAR _......................................

4.3. ESTRATÉGIA POR MAXIMIZAÇÃO DO ÍNDICE DE SHARPE ............................... 77

4.4. ESTRATÉGIA POR MAXIMIZAÇÃO DA UTILIDADE ESPERADA .......................... 79

4.5. ESTRATÉGIA POR MINIMIZAÇÃO DO COEFICIENTE DE GINI ESTENDIDO...............81

4.6. ESTRATÉGIAS POR ANÁlISE DE REGRESSÃo LINEAR CONDICIONADA AO

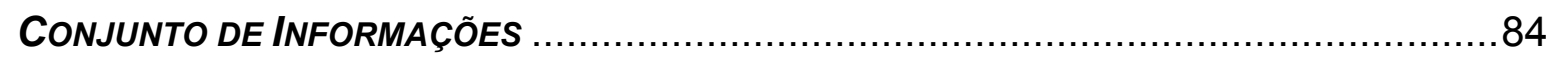

4.7. ESTRATÉGIA POR ANÁlISE DE REgRESSÃo LINEAR CONDICIONADA AO ConJunto de INFORMaÇões E Ao PeRÍodo de CARREgamento ............................ 88

4.8. EstratéGIa Por MínIma VARIÂNCIa Condicionada ao PERÍodo de CARREGAMENTO. .92

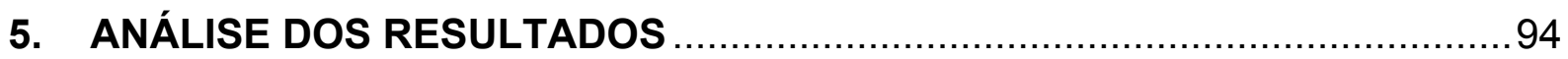

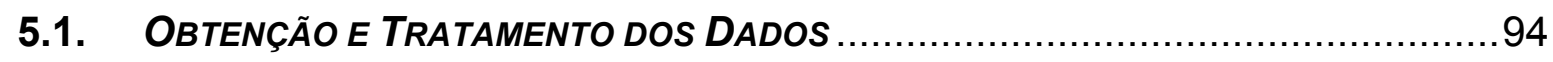

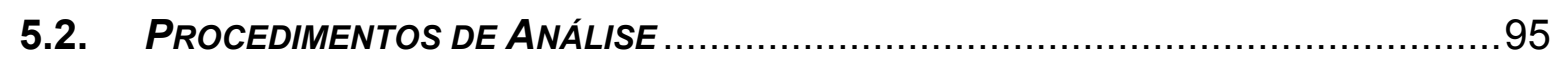

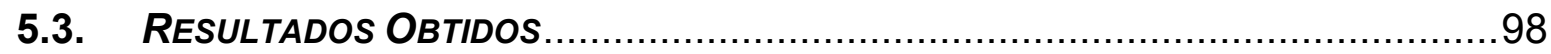

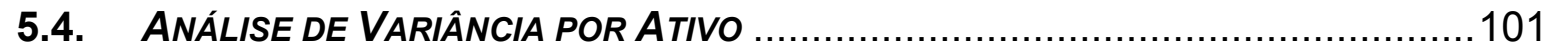

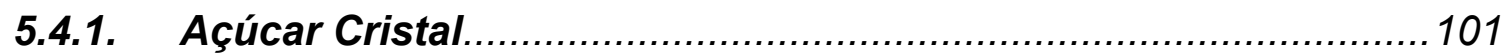

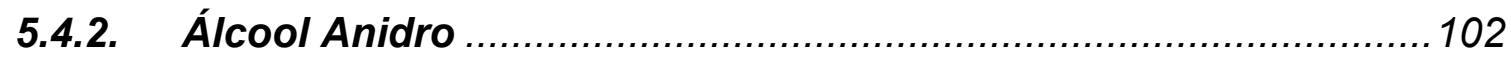

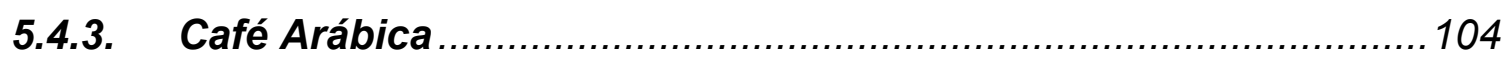

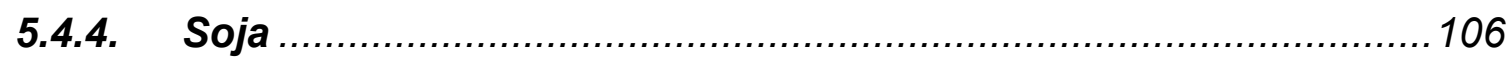

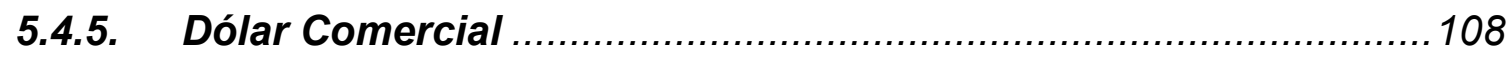

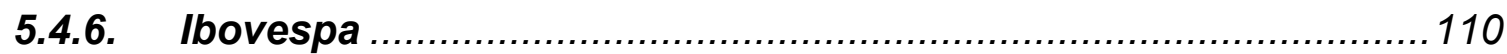

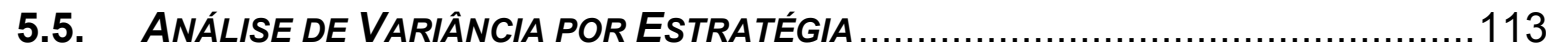

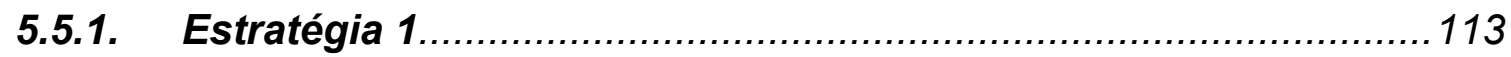

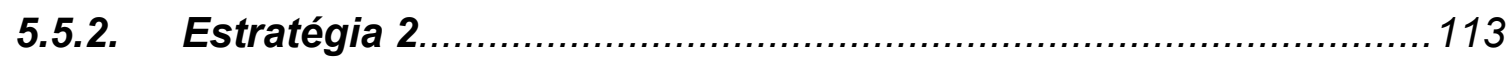




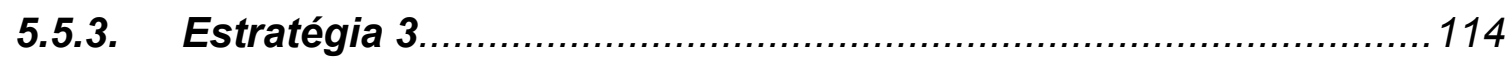

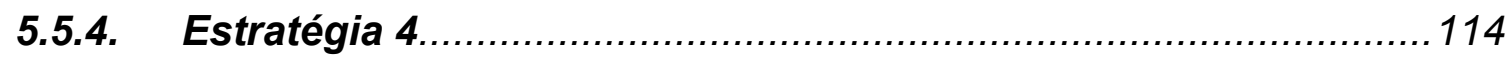

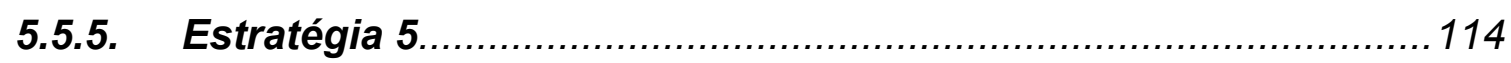

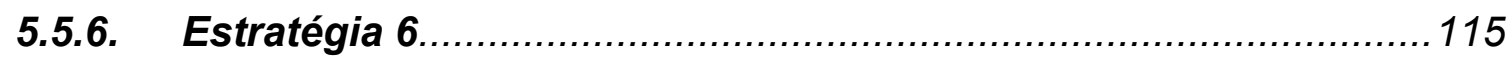

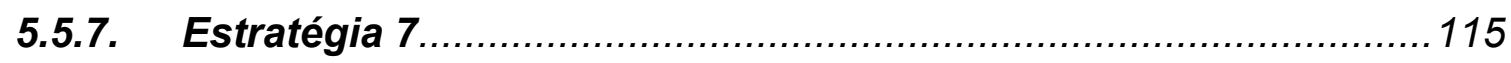

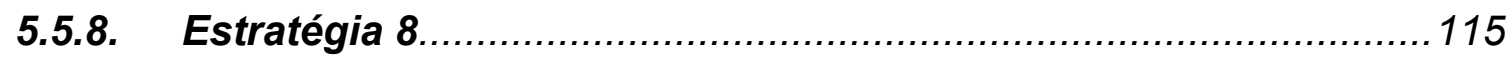

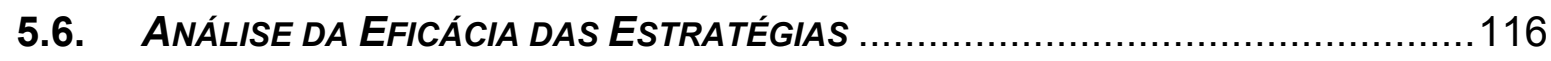

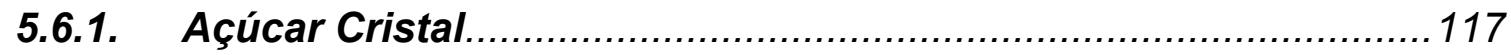

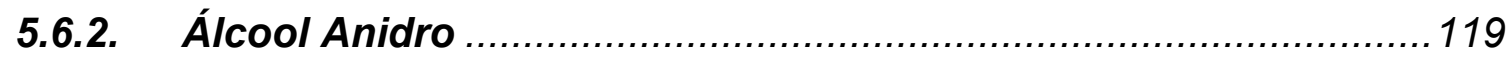

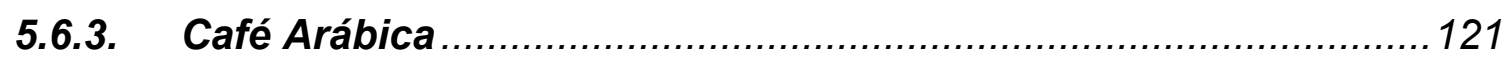

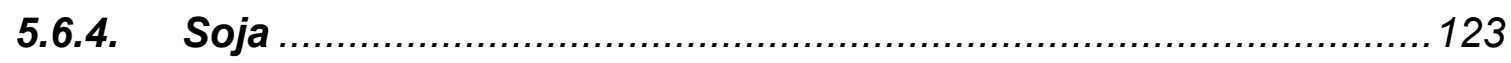

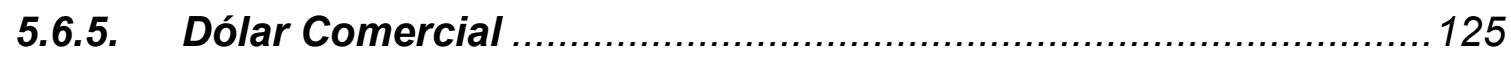

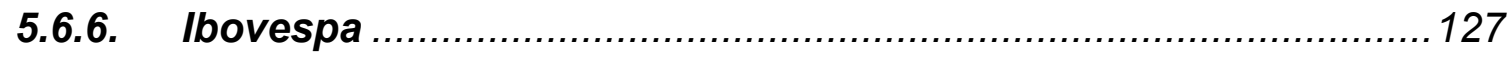

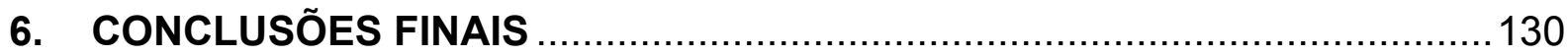

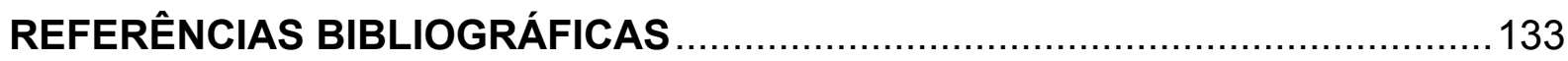

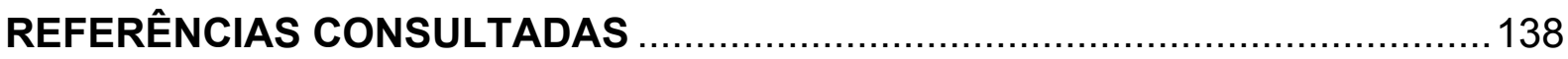

APÊNDICE - CONCEITO DE DOMINÂNCIA ESTOCÁSTICA …..........................141

ANEXOS - TESTE DE NORMALIDADE 


\section{INTRODUÇÃO}

A economia é basicamente dividida em setores, cada qual composto por um conjunto de cadeias produtivas com finalidades específicas. A gestão dos riscos envolvidos nessas cadeias é fundamental à viabilidade do negócio, sejam elas do setor primário, do secundário, sejam do terciário.

Uma cadeia produtiva pode ser definida, de forma generalizada, como um conjunto de elementos, que interagem entre si em um processo produtivo, cujo principal objetivo é ofertar produtos e/ou serviços ao consumidor final. A gestão dos riscos nela envolvidos constitui um processo de identificação, de mensuração e de controle dos diversos fatores exógenos, de aspectos negativos, aos quais ela está exposta. Fatores que, por sua vez, podem-se originar de riscos operacionais do próprio negócio, de riscos legais, de riscos de estratégias adotadas e/ou de riscos financeiros.

Com as diversas mudanças ocorridas na economia mundial nos últimos anos, a ciência econômica tem sido cada vez mais chamada a cumprir seu papel fundamental, de alocar a ofertar de recursos escassos de forma eficiente, de modo a atender às necessidades básicas dos indivíduos. Dessa forma, o desenvolvimento de produtos que permitam às cadeias produtivas cumprirem seu papel no ambiente econômico, eliminando ou mitigando o efetivo de fatores negativos, em caso de ocorrência, tem sido uma ação constante das instituições, freqüentemente encontrada na literatura da área.

Considerando especificamente as cadeias produtivas agrícolas ${ }^{1}$, podem ser considerados riscos operacionais inerentes a elas, os seguintes: a indisponibilidade de insumos necessários para iniciar a produção de um produto; a possibilidade de ocorrência de intempéries climáticas; o ataque de pragas; a adubação inadequada do solo; a falta ou a inadequação de processadores dos produtos in natura, para serem levados até os comerciantes, e/ou a indisposição destes em levar o produto

\footnotetext{
${ }^{1} \mathrm{O}$ conceito de cadeia produtiva agrícola é apresentado no capítulo 2.
} 
processado ao consumidor final. Por conseguinte, a imposição de normas de qualidade, a proibição ao uso de determinados produtos químicos e/ou a exigência de adequações sanitárias podem ser considerados riscos legais. Em se tratando da decisão de iniciar a produção em período errado, uma expectativa errada de demanda futura resultará em excesso ou em falta de um produto ao consumidor, caracterizando-se como risco de estratégia.

Ao considerarem-se os aspectos financeiros envolvidos nessa cadeia, como a volatilidade do preço dos insumos e dos produtos finais no mercado, a variação das taxas de juros de financiamento da produção e a variação da taxa de câmbio, quando considerado um ambiente de comércio com o exterior, conclui-se que constituem riscos financeiros iminentes, podendo levar a prejuízos financeiros. Entretanto esses riscos são passíveis de imunização ou hedging ${ }^{2}$. O hedging tem, como principal objetivo, buscar proteção a certo fator de risco que possa trazer prejuízos financeiros a determinado indivíduo ou instituição, eliminando ou minimizando a exposição a esse fator.

As operações ou as estratégias de hedging são realizadas com instrumentos de derivativos ${ }^{3}$, os quais têm 0 objetivo de gerenciar 0 risco financeiro adequadamente. A proliferação do uso desses instrumentos deu-se a partir dos anos 70. Sua utilização nas operações de hedging funciona como um contrato de seguro, propiciando proteção contra os efeitos adversos de variáveis sobre as quais os indivíduos e as instituições não têm controle.

Nesse contexto, este trabalho consiste em estudar as principais estratégias de hedging estáticas, apresentadas pela literatura, utilizando contratos futuros, com o propósito de serem utilizadas como possível instrumento de proteção contra o risco de prejuízo financeiro pelo produtor rural. A hipótese que se propõe, para o desenvolvimento da pesquisa, é que o produtor, elemento fundamental da cadeia produtiva agrícola, tenha eminente o risco financeiro de não conseguir vender o produto final de sua produção no mercado, ao preço mínimo necessário para

\footnotetext{
${ }^{2} \mathrm{O}$ termo hedging e seus derivados não são palavras da língua portuguesa; por isso, não são encontradas em dicionários dessa língua. No entanto, são termos comumente utilizados no mercado financeiro e, por sua vez, serão utilizados ao longo deste trabalho. Seu sentido é proteção, trava ou seguro.

${ }^{3}$ A definição deste conceito é apresentada em capítulo específico.
} 
remunerar os custos produtivos. Frente a tal risco, poderia hedgear sua produção com contratos no mercado futuro, para garantir o preço mínimo de venda.

\subsection{Situação-Problema}

A cadeia produtiva agrícola pode ser considerada como o cerne do setor primário da economia, composta por um conjunto de empresas, ou de sistemas, interagindo entre si, com o objetivo de ofertar produtos e/ou serviços ao mercado consumidor. Os agricultores ou os produtores agrícolas (agentes produtivos), peças fundamentais dessa cadeia, por sua vez, coordenam os sistemas produtivos, cuja função é prover o elo seguinte da cadeia com matérias-primas vegetais e animais. No entanto duas questões são fundamentais para que os agentes produtivos consigam viabilizar o sistema produtivo: o financiamento da produção e a remuneração dos custos de produção. Entretanto, embora se tenha consciência de que a questão de financiamento da produção seja fundamental, este trabalho foca a questão de remuneração dos custos de produção do agente produtivo.

Os riscos intrínsecos a esses sistemas produtivos podem ser, a grosso modo, classificados em riscos não-financeiros e financeiros. Os riscos não-financeiros englobam os riscos operacionais, legais e estratégicos; já os riscos financeiros são derivados da volatilidade excessiva dos preços, das taxas de juros e de câmbio, que podem afetar, de forma decisiva os sistemas produtivos. Neste caso, impossibilita-se a remuneração dos custos de produção e, por isso, inviabiliza-se a comercialização do produto final, uma vez que os agentes produtivos transacionam seus produtos em uma data posterior à data em que iniciaram a produção, vivendo, dessa forma, a incerteza quanto ao preço de mercado com que os produtos serão negociados.

Para que os sistemas produtivos coordenados pelos produtores agrícolas sejam viáveis, de forma a permitir o fluxo dos produtos dentro da cadeia produtiva, é necessário que, pelo menos, o resultado financeiro obtido com a comercialização do produto final dos sistemas produtivos remunere os fatores de produção utilizados pelos produtores, como os recursos naturais, o trabalho e o capital. Dessa forma, os produtores agrícolas não podem correr o risco de, no momento de negociar seu 
produto final, serem remunerados com um preço de mercado em patamar inferior aos seus custos de produção.

Surge, então, a necessidade de utilizar estratégias de hedging que mitiguem tal risco, assegurando, dessa forma, um preço de venda para os produtos, que remunere os agentes produtivos permitindo a continuidade da cadeia produtiva.

\subsection{Objetivo do Trabalho}

Os contratos de derivativos, como termos, futuros, opções e swaps, são instrumentos possíveis de utilizar para estruturar estratégias de hedging, com a finalidade de mitigar riscos financeiros. No entanto, além desses derivativos mais tradicionais, há também dois novos produtos, os Certificados de Depósitos Agropecuários (CDA) e os Warrants Agropecuários (WA), que são títulos de créditos, oficializados pela Lei $\mathrm{n}^{\circ} 11.076$ de 30 de dezembro de 2004, e possíveis instrumentos mitigadores de tal risco.

Esses novos títulos foram originalmente estruturados para servir como instrumentos de financiamento para o agronegócio. Eles se caracterizam pela emissão exclusiva do agente produtor agrícola que possui o produto e o deposita em um armazém, lastreando a emissão dos títulos na mercadoria agrícola depositada. $\mathrm{O}$ CDA e o WA poderão integrar o mercado físico da mercadoria, a comercialização física, os mercados a termos e futuros e os derivativos agrícolas, através de operações casadas no mercado à vista e no mercado futuro. Dessa forma, apresentam características que permitem sua negociação em bolsas de mercadorias, podendo também servir de instrumentos para estruturar estratégias de hedging.

Dentre os instrumentos citados como passíveis de utilização para estruturar estratégias de hedging, o presente trabalho focará seu estudo nos contratos futuros, por se tratarem de instrumentos negociados em ambiente transparente, regulamentado e normatizado, como o das bolsas de mercadorias. A utilização desses contratos, como instrumento de hedging, pelo produtor agrícola, permite que ele mitigue riscos financeiros durante o processamento dos sistemas produtivos e 
que consiga a remuneração ideal de seu produto final, viabilizando, assim, o fluxo da cadeia produtiva.

Nesse contexto, o objetivo principal deste trabalho é fazer uma revisão das diferentes estratégias de hedging estáticas estudadas na literatura, analisando, empiricamente, o comportamento delas, quando empregadas na gestão financeira de produtos agrícolas no mercado brasileiro, a fim de determinar se há uma estratégia ideal para todos os ativos, ou uma estratégia ideal para cada ativo.

A construção de uma estratégia de hedging no mercado futuro consiste em determinar o número de contratos negociados em bolsas de mercadorias, necessário para assegurar a remuneração de uma quantidade física de mercadoria específica. Essa estratégia caracteriza-se como estática por, uma vez definido o número de contratos a comprar, ou a vender, não mais se alterar até o final do período durante o qual se deseje hedgear o ativo físico no mercado à vista. As estratégias serão abordadas sob o ponto de vista de um portfólio composto de apenas dois ativos: um produto físico (commodity agrícola) no mercado à vista e um financeiro (contratos) no mercado futuro.

A questão de fundo que se pretende tratar é a adequação de estratégias clássicas de hedging financeiro a commodities agrícolas do mercado brasileiro, uma vez que as premissas nas quais a maior parte da literatura se baseia consideram mercados líquidos, sem os custos de transação e admitem a inexistência de sazonalidade, o que naturalmente não ocorre no mercado agrícola. Por exemplo, commodities como o álcool, ainda que negociadas no mercado futuro, não apresentam liquidez, além de sofrerem grandes flutuações em seus preços, prejudicando, assim, a formação do preço justo.

Entretanto, apesar de este trabalho ter considerado, para estudo, apenas as estratégias caracterizadas como estáticas, analisou-as sob um olhar dinâmico, uma vez que se rebalanceou o portfólio semanalmente. Essa prática permitiu readequar a posição em contratos futuros, utilizados com a finalidade de hedgear a posição mantida no mercado à vista, ao longo do período em que sustentou a estratégia. Isso decorre de os preços à vista e futuro serem elementos fundamentais, utilizados 
pelas estratégias, na determinação da razão ótima de hedging e mudarem à medida que incorporam informações correntes.

Ainda que o foco de estudo sejam em apenas commodities agrícolas, o trabalho propõe-se também aplicar as mesmas estratégias a produtos financeiros, como a taxa de câmbio e o índice Bovespa, por apresentarem maior liquidez no mercado, além de serem indicativos importantes da economia do país. O propósito dessa aplicação é verificar se há diferença de comportamento nas estratégias quando, aplicadas a ativos agrícolas e a ativos financeiros, e caso haja, identificar as possíveis causas dela.

Dessa forma, o desenvolvimento do trabalho abrangerá:

i) O estudo, a implementação e a análise de diferentes estratégias de hedging estáticas;

ii) A mensuração e a análise dos resultados financeiros obtidos por estratégia, para cada ativo;

iii)A análise de variância sobre os resultados financeiros médios, por estratégia, sob a ótica de um mesmo ativo;

iv) A análise de variância sobre os resultados financeiros médios, por ativo, sob a ótica de uma mesma estratégia;

v) A análise da eficácia das estratégias, sob a ótica de um mesmo ativo;

vi) A identificação da eventual superioridade de uma estratégia sobre as demais, para um mesmo ativo. 


\subsection{Metodologia de Pesquisa}

Partindo do raciocínio de Gil (1999) e de Lakatos e Marconi (1993), apud Silva e Menezes (2001, p.25), "o método científico é o conjunto de processos e operações que devem ser empregados na investigação, ou seja, é a linha de raciocínio adotada no processo de pesquisa".

Com relação à natureza deste trabalho, podemos classificá-lo como uma pesquisa aplicada, uma vez que, partindo de um objetivo, pretende-se gerar conhecimentos de aplicação prática dirigidos na solução de problemas. A abordagem da situação-problema é realizada por pesquisa quantitativa, uma vez que requer o uso de recursos e de técnicas estatísticas. Com relação ao objetivo da pesquisa, pode-se considerá-la como descritiva, pois visa a fazer inferência sobre uma população, com base em uma amostra, envolvendo o uso de técnicas padronizadas de coletas de dados.

Com relação ao procedimento técnico do trabalho, trata-se de uma pesquisa bibliográfica, elaborada a partir de material já publicado, como livros, artigos etc., além de utilizar uma série histórica de dados referentes às variáveis utilizadas.

\subsection{Estrutura do Trabalho}

O presente trabalho está dividido em, basicamente, seis grandes tópicos: a descrição da cadeia produtiva do agronegócio; a fundamentação teórica dos conceitos utilizados; a apresentação das estratégias de hedging estáticas; a análise dos resultados e a conclusão final.

O capítulo 2 refere-se à descrição e à definição da cadeira produtiva do agronegócio e dos riscos nela envolvidos, além de se apresentarem os ativos utilizados no trabalho. No capítulo 3 , expõem-se as definições teóricas dos conceitos, que são utilizados nas estruturações das estratégias de hedging. 
O capitulo 4 apresenta as estratégias de hedging estáticas encontradas com maior freqüência na literatura. Elas são explicitadas de forma a expor sobre quais premissas se fundamentam para determinar a razão ótima segundo a qual se posicionar em contratos no mercado futuro, com o propósito de minimizar o risco de manter uma posição, em determinada quantia, de um ativo no mercado à vista.

O capítulo 5 refere-se à análise dos resultados do trabalho, o qual é composto pelo método de pesquisa utilizado na obtenção dos dados, ao procedimento de análise, à determinação da razão ótima de hedging e das medidas de eficácia das estratégias, à determinação dos resultados financeiros, à análise de variância por ativo, à análise de variância por estratégia e à análise das medidas de eficácia das estratégias. Finalmente,no capítulo 6 , apresentam-se as conclusões do trabalho. 


\section{A CADEIA PRODUTIVA DO AGRONEGÓCIO}

\subsection{Conceito de Agronegócio}

Como afirmou Watanabe (2005), o conceito de agronegócio vem da ciência econômica. Esse termo não era utilizado até o início do século 20 , porque as famílias produziam seus próprios alimentos e negociavam apenas o excesso no mercado local.

Tempos mais tarde, os sistemas produtivos familiares modernizaram-se e se tornaram especializados deixando de operar o ciclo todo do produto. Dessa forma, atividades como a manufatura e a distribuição passaram a ser realizadas por outras firmas, no entanto, ainda envolvidas no mesmo sistema de produção, o qual era composto por um conjunto de processos e de instituições ligadas por objetivos comuns. Tal sistema foi denominado de agribusiness (negócio agrícola ou agronegócio) em 1957, nos Estados Unidos, por Ray Goldberg e John Davis.

Nos anos 50, diversos autores analisando a formação do complexo agroindustrial, apresentaram o conceito de network, ou rede de negócios, que nada mais era que uma firma que forma com outras sua rede de negócios. Tal conceito, quando aplicado ao complexo agroindustrial, é definido como um conjunto de firmas responsáveis pela produção de uma mercadoria agrícola, chamado de cadeia agrícola. Analisando esse conceito sobre o sistema produtivo, uma rede de negócios pode ser considerada como firmas que mantêm um relacionamento de negócios vertical e horizontal entre si.

O agronegócio representa uma evolução da cadeia produtiva através do desenvolvimento de sistemas, não apenas limitado ao setor produtivo, mas também considerando a indústria e o comércio. Logo, segundo Watanabe, conclui-se que a agricultura, a agroindústria e o distribuidor não podem ser considerados separadamente, devidos a suas inter-conexões e aos relacionamentos entre os participantes, que não se restringe apenas ao ato de compra e venda. 
Castro (2000) afirma que o conceito de agronegócio, ou negócio agrícola, é uma abordagem aplicada da teoria geral dos sistemas. Um sistema é, na definição do autor, um conjunto de componentes interativos o qual se inicia com o estabelecimento de seus objetivos, seguido da definição de seus limites, subsistemas componentes e contexto externo. Ao definirem-se limites e hierarquias, estabelecem-se as interações de seus subsistemas componentes, mensuram-se suas entradas e saídas e os respectivos desempenhos intermediário (subsistemas) e final (sistemas), de acordo com a figura 1.

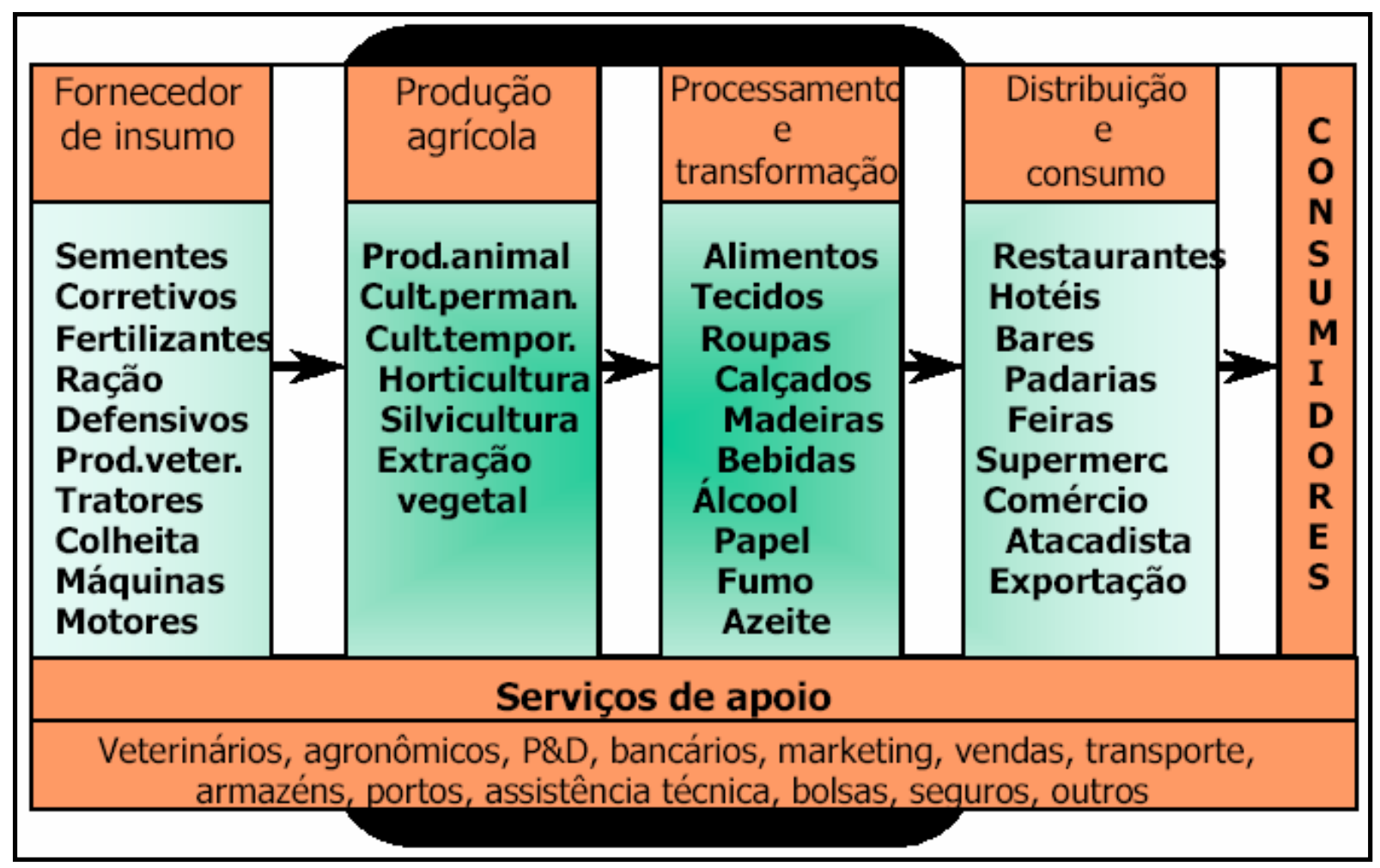

Figura 1 - Modelo de Agronegócio

Fonte: Castro (2000)

Para o autor, o agronegócio compõe-se de cadeias produtivas as quais possuem, entre seus componentes, os sistemas produtivos que operam em diferentes ecossistemas ou sistemas naturais.

\subsection{Conceito de Cadeia Produtiva}


O conceito de cadeias, ou filières, segundo Morvan (1985), apud Zylbersztajn (1995, p. 124), originou-se na escola de economia industrial francesa. Esse conceito se aplica à seqüência de atividades que transformam uma commodity em um produto pronto para o consumidor final.

Cadeia produtiva, de forma simplificada, pode ser definida como um conjunto de elementos ("empresas ou sistemas") que interagem em um processo produtivo, para a oferta de produtos ou de serviços ao mercado consumidor, Silva $(2005$, p.1). Para Castro (2000, p. 2), a cadeia produtiva é o conjunto de componentes interativos, incluindo os sistemas produtivos, os fornecedores de insumos e de serviços, os industriais de processamento e de transformação, os agentes de distribuição e de comercialização, além dos consumidores finais.

A figura 2 ilustra a representação esquemática, típica de cadeia produtiva de mercadorias de origem vegetal, com seus principais componentes e fluxos, segundo a metodologia da EMBRAPA.

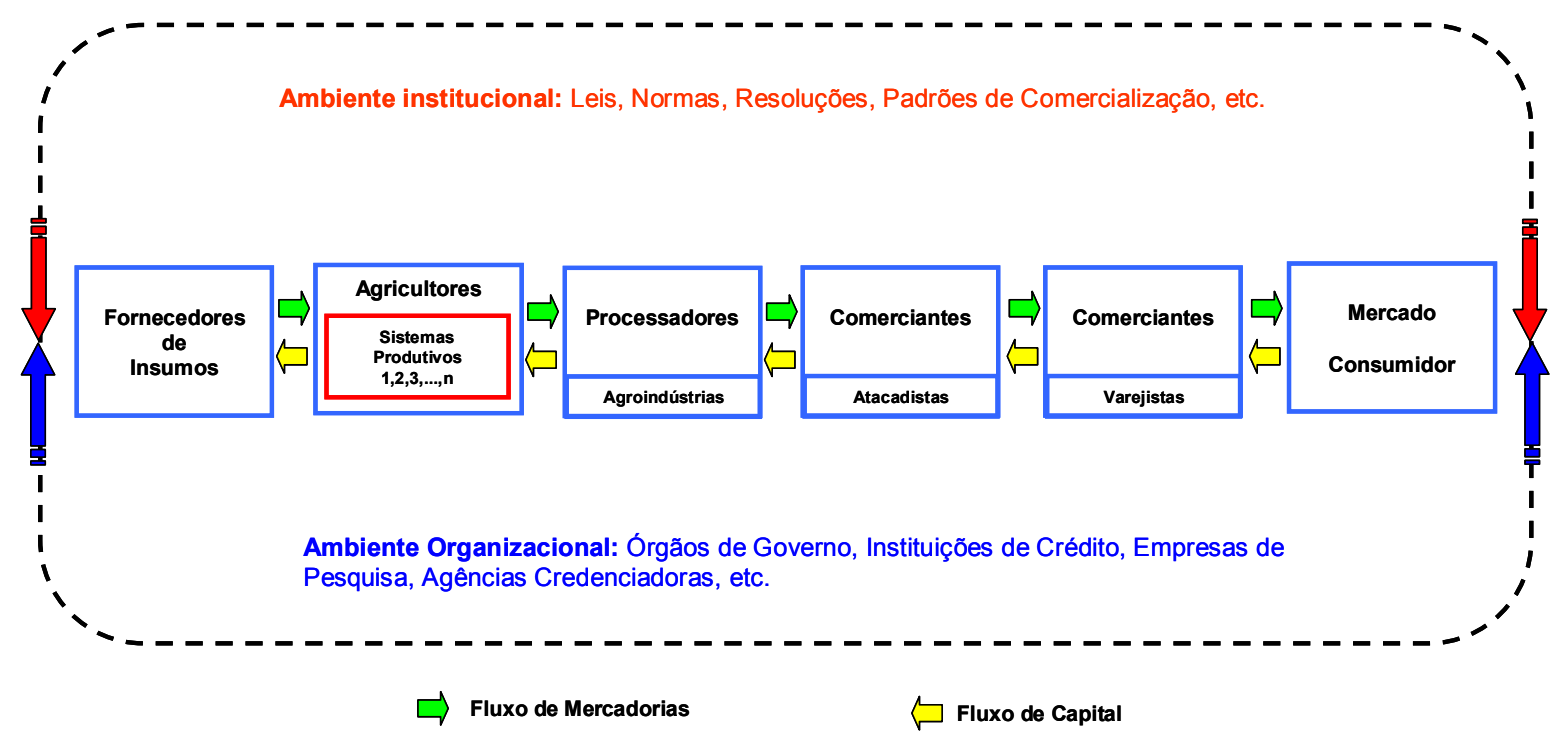

Figura 2 - Modelo Geral da Cadeia Produtiva, segundo metodologia da EMBRAPA Fonte: Castro (2000) e Silva (2005)

Assim, Silva define cada componente da cadeia produtiva: 
a) Fornecedores de Insumos: referem-se às empresas que têm, por finalidade, ofertar produtos, tais como: sementes, calcário, adubos, herbicidas, fungicidas, máquinas, implementos agrícolas e tecnologias;

b) Agricultores: são os agentes cuja função é proceder ao uso da terra para a produção de commodities, como madeira, cereais e oleaginosas. Essa produção realiza-se em sistemas produtivos, como fazendas, sítios ou granjas;

c) Processadores: são agroindustriais que podem pré-beneficiar, beneficiar ou transformar os produtos in-natura. Exemplos: (a) pré-beneficiamento: são as unidades operacionais encarregadas da limpeza, da secagem e da armazenagem de grãos; (b) beneficiamento: são as unidades operacionais que padronizam e empacotam produtos, como arroz, amendoim, feijão e milho de pipoca; (c) transformação: são as unidades operacionais que processam uma determinada matéria-prima e a transformam em produto acabado, como óleo de soja, cereal matinal, polvilho, farinhas, álcool e açúcar etc.;

d) Comerciantes: os atacadistas são os grandes distribuidores, que possuem, por função, abastecer redes de supermercados, postos de vendas e mercados exteriores. Já os varejistas constituem os pontos cuja função é comercializar os produtos junto aos consumidores finais e

e) Mercado Consumidor: é o ponto final da comercialização, constituído por grupos de consumidores. Esse mercado pode ser doméstico, se localizado no país, ou externo, quando em outras nações.

Outra visão de cadeia produtiva agroindustrial é defendida por Batalha (1997, p. 26), o qual apresenta que a cadeia pode ser segmentada em três macrossegmentos:

$\checkmark$ Comercialização: representa as empresas que estão em contato com o cliente final da cadeia de produção e que viabilizam o consumo e o comércio dos produtos finais; 
$\checkmark$ Industrialização: representa as firmas responsáveis pela transformação das matérias-primas em produtos finais, destinados ao consumidor, que pode ser uma unidade familiar ou outra agroindústria;

$\checkmark$ Produção de matérias-primas: reúne as firmas que fornecem as matérias-primas, que são insumos, para que outras empresas avancem no processo de produção das mercadorias finais.

No gerenciamento dos sistemas produtivos, busca-se, em geral, maximizar a produção biológica e/ou econômica, minimizar os custos, maximizar a eficiência do sistema para determinado cenário sócio-econômico, atingir determinados padrões de qualidade, proporcionar sustentabilidade ao sistema e garantir produtividade à mercadoria, Castro $(2000$, p.3).

No entanto, para que o gerenciamento dos sistemas produtivos seja otimizado de forma a atingir todos os seus objetivos, é necessário que o segundo componente da cadeia (agricultores), seja adequadamente remunerado e consiga viabilizar esse elo da cadeia, alimentando o componente seguinte (produtores). Nesse ponto, há necessidade de um ambiente organizacional efetivo, com a atuação das instituições financeiras fornecendo instrumentos que supram as necessidades do segundo componente.

\subsection{Riscos na Cadeia Produtiva do Agronegócio}

O setor agrícola é caracterizado por uma forte exposição ao risco, o qual é categoricamente dividido em risco de preço ou financeiro e risco não-financeiro ou de produção. De acordo com Meuwissen et al. (1999), o risco de preço ou financeiro tende a aumentar, à medida que aumenta a liberalização e globalização do comércio; enquanto o risco não-financeiro ou de produção se eleva devido ao aumento das exigências por qualidade para alguns produtos, regras relativas ao uso de insumos como o uso de produtos químicos para plantas e de remédios para animais e variações climáticas trazendo mudanças como níveis e duração de períodos de intensidades de ondas de calor, de intenso frio, de intensa precipitação pluviométrica, etc. 
Como exposto em European Commission (2001) [...], o risco na agricultura não se refere somente ao produtor agrícola individualmente, e, sim, à sociedade como um todo, uma vez que o comportamento de aversão a riscos de um produtor pode levar a uma alocação de recursos insuficiente à produção, resultando em uma alocação de recursos não-otimizada e, conseqüentemente, a uma menor geração de riqueza.

\subsubsection{Categorias de Riscos na Agricultura}

Alguns riscos corridos por produtores agrícolas são peculiares a sua atividade; já outros são comuns a quaisquer tipos de negócios, podendo, no entanto, se inter-relacionar, conforme USDA $^{4}$ [...] (1999) e Hardaker et al. (2004). Estes podem ser categorizados em:

$\checkmark$ Riscos pessoais ou humanos: são relativos à morte, a doença ou a ferimentos. Esses riscos são comuns a todos os operadores de negócios ou empregados;

$\checkmark$ Riscos de ativos: são os associados a roubos, a incêndios e a outras perdas e danos de equipamentos, de prédios e de outros ativos agrícolas usados na produção.

$\checkmark$ Riscos de produção ou de resultados: são freqüentemente relativos ao tempo, como excesso ou insuficiência de chuva, gelo, ou temperaturas extremas, incluindo também riscos como doenças de plantas e animais.

O risco de resultado é medido pela variabilidade do resultado, ou seja, pela variabilidade relativa da série de resultados sobre o valor médio. A variabilidade de resultado, para uma colheita, oscila consideravelmente de região para região, dependendo de clima, de tipo de solo e de método de produção;

$\checkmark$ Risco de preço: é o risco de queda dos preços dos produtos finais, ou do aumento dos preços dos insumos utilizados, depois de a decisão de

\footnotetext{
${ }^{4}$ United States Department of Agriculture
} 
produção ter sido tomada. $O$ risco de preço é medido pela aleatoriedade dos preços. Oposto aos resultados, os preços não seguem uma tendência e a volatilidade dos preços para muitos produtos é, muitas vezes, mitigada por medidas de ajuda;

$\checkmark$ Riscos institucionais: é o risco associado a mudanças na estrutura política, agrícola, por exemplo, as quais interferem na produção e nas decisões de mercado e, conseqüentemente, nos resultados financeiros da unidade fabril agrícola;

$\checkmark$ Riscos financeiros; incluem custo de capital, risco de câmbio, falta de liquidez e perda do patrimônio.

\subsubsection{Percepção de Riscos pelos Produtores Agrícolas}

Conforme exposto pela European Commission (2001) [...] e por Meuwissen et al. (2001), a exposição a riscos objetivamente varia de produtor para produtor. Para que a estratégia de mitigação adotada seja bem-sucedida, depende não apenas de determinar objetivamente a exposição a eles, mas também se eles são subjetivamente percebidos pelos produtores. Essa percepção varia de produtor para produtor, associada à sua experiência e à aversão a riscos.

Segundo afirma o relatório da European Commission, na avaliação da possibilidade de sucesso de uma nova ferramenta de gerenciamento de risco, é importante manter em mente que a exposição a ele seja objetivamente determinada e que a percepção ao mesmo pode diferir consideravelmente de indivíduo para indivíduo. Enquanto um instrumento é limitado a ser bem-sucedido por razões objetivas, uma boa taxa de percepção do risco pelo indivíduo não é automaticamente garantida, pelo fato de o risco percebido poder ser menor, por uma falha cognitiva.

De acordo com a USDA (1999) [...], a quantificação do risco é o primeiro passo a ser tomado, em seguida a eficácia das diferentes formas utilizadas para avaliá-lo deve ser mensurado. A adoção de uma estratégia, basicamente, exige a avaliação do trade-off entre os custos para se reduzirem a exposição ao risco e a expectativa de retorno. A estratégia adotada irá diferir de acordo com o 
relacionamento entre os vários riscos deparados e os custos dos vários instrumentos possíveis de mitigação de acordo com a renda e a riqueza do produtor agrícola, como também com sua capacidade de percepção do risco.

Estratégias de gerenciamento de riscos relacionados à interação de diferentes unidades fabris incluem diversificação, contratos de produção e integração vertical; hedging com contratos futuros e contratos de opções; participação em fundos mútuos e seguros. Outras estratégias, fora desse escopo, incluem confiança na assistência de órgãos públicos, no caso de desastres ou de emergências; ou aumento da participação da renda, por meio de outras fontes, fora da agricultura.

A USDA (1999) [...] e a European Commission (2001) [...], apresentaram as premissas sobre as quais as estratégias de gerenciamento de risco são fundamentadas. A premissa de diversificação fundamenta-se no princípio que retornos de várias empresas, atividades ou ativos, não são perfeitamente correlacionados. Dessa forma, uma perda em resultado oriundo de uma empresa, atividade ou ativo, pode ser compensado pelo resultado positivo de outra, reduzindo o risco como um todo.

A premissa baseada em contratos de produção fundamenta-se no princípio que o agricultor, que mantém completa responsabilidade por todas as decisões de gerenciamento da produção, concorda em vender uma commodity, a certo preço, a um comprador antes de essa commodity estar no mercado. Esses contratos baseiam-se ou em um preço fixado entre as partes, ou dependem do desenvolvimento do preço futuro da commodity e, além de reduzir o risco de preço, fornecem ao agricultor uma oportunidade de diferenciar seus produtos da produção em massa, atraindo um valor econômico por isso. Já na premissa de integração vertical fundamenta-se o princípio que as firmas mantêm o controle de uma commodity, através de dois ou mais níveis de atividades. Dentre muitas razões que a justificam, a redução do risco de preço é uma delas, uma vez que ela ajuda a reduzir os riscos associados à variação na qualidade e na quantidade dos insumos utilizados no processo produtivo. 
A premissa de hedging com contratos futuros e contratos de opções fundamenta-se no princípio que esses contratos permitem hedgear o risco de preço, travando o preço de uma commodity que se deseja comprar ou vender em uma data futura. No entanto, esses contratos diferem em três importantes questões dos contratos de produção: a) são padronizados e, por isso, podem mais facilmente ser negociados; b) são negociados em bolsas sob regras e regulamentações e c) enquanto nos contatos de produção envolve-se a entrega do produto no seu vencimento, nos contratos futuros e nos contratos de opções, isso raramente ocorre.

As negociações de contratos futuros permitem a transferência de risco de preço de uma firma, que deseja menos risco (hedger), para outra, que aceita mais risco, em troca de um lucro. Um hedger pode ser um agricultor, um negociador da mercadoria ou um processador, que deseja fechar um preço para uma commodity, que necessitará comprar ou vender mais tarde, no mercado à vista.

O hedging também pode ser realizado sobre um contrato de opção. Esse contrato dá seu adquirente o direito, não a obrigação, de tomar uma posição futura a um preço especificado, chamado de strike, em um período específico. O custo para garantir esse direito é dado pelo preço pago pela opção.

A premissa baseadas em seguros, fundamentam-se no princípio de agrupar os riscos deparados por um grande número de pessoas, em uma única categoria. Essas pessoas pagam um prêmio em dinheiro a um fundo comum, o qual é utilizado para cobrir eventuais perdas por qualquer dos indivíduos desse grupo. As condições básicas para a realização de um seguro é o gerenciamento dos efeitos adversos da "informação assimétrica" e a superação das implicações dos "riscos sistemáticos". A questão relativa à informação assimétrica diz respeito ao comprador do seguro e à companhia seguradora, quando não têm as mesmas informações sobre o ativo assegurado, de forma a se estimarem as probabilidades de ocorrência de perda; com relação ao risco sistemático refere-se ao problema de a ocorrência do evento negativo, ou da perda, atingir todas as pessoas ao mesmo tempo. Caso isso ocorra, o fundo formado pelos prêmios, para ressarcir as perdas, não é suficiente para cobrir todos os indivíduos. 
Quando relacionados à agricultura, os seguros podem estruturados de forma a assegurar a rentabilidade de colheitas, ou seja, caso ocorra de o resultado agrícola ficar abaixo de um limite estipulado, o agricultor tem o direito de ser ressarcido da perda; assegurar contra perdas catastróficas, resultados de doenças e ou de desastres naturais; assegurar o preço de venda ou compra de um produto; assegurar a receita, que é uma combinação do seguro de preço e de rentabilidade, tendo a vantagem de ser mais barato que os dois, uma vez que o risco de um mau resultado é menor e assegurar resultados líquidos da unidade fabril.

A premissa baseada em resseguros e seguros agregados é fundamentada no princípio de que a companhia seguradora primária transfere parte da responsabilidade da cobertura do seguro, a uma ou a mais companhias de seguro. Este tipo de seguro é importante, para assegurar companhias que correm riscos correlacionados e, por isso, sofrem o risco de grandes perdas. A baseada sem seguros agregados fundamenta-se na união de companhias de seguros de modo assegurar a cobertura de determinado risco. E finalmente a premissa de fundo mútuo, que são constituídos com finalidades de cobrir perdas totais ou parciais de seus participantes ou cotistas.

\subsection{Mercados e Influências sobre a Formação de Preços}

O risco de preço das commodities tem atualmente uma grande importância mundial, principalmente pelo impacto que causa sobre a economia de países desenvolvidos e em desenvolvimento. Esses últimos podem ser considerados, em sua maioria, os responsáveis pela produção, processamento e transformação e negociação da commodity, todos envolvidos em atividades de comércio no mercado à vista e pela entrega física do produto. As negociações no mercado à vista, são caracterizadas pela entrega imediata do produto, ou pela existência há um intervalo mínimo de entrega devido às restrições técnicas o que é mais usual. A responsabilidade de execução comercial pode ficar nas mãos ou do vendedor, ou do comprador ou de um intermediário. 
Quando considerado os riscos referentes às transações de commodities Geman (2005, p. 3), elenca os quatro maiores riscos envolvidos, que são o risco de preço, o risco de transporte, o risco de entrega e o risco de crédito.

O risco de preço refere-se à oscilação excessiva no preço de uma commodity, podendo ocasionar em prejuízo financeiro ao agente que a comercializa. No entanto, o desenvolvimento de mercados de derivativos - contratos a termo, futuro e opções - tem pavimentado o caminho para gerenciamento desses riscos e estruturado contratos para otimizar a oferta e demanda dos produtos, entre eles as commodities, além de servir como instrumentos de hedging.

O risco de transporte refere-se à deterioração total, ou parcial, dos bens durante o transporte, os quais podem ser classificados como riscos comuns ou como riscos extraordinários (guerras, greves e tumultos). O exportador ou o comprador assume o risco de transporte do bem, a menos que seja formalizado um contrato de seguro que cubra tal risco.

Segundo Geman todas as bolsas de mercado futuro no mundo cotam os preços das mercadorias FOB (free on board). Caso a negociação de uma mercadoria seja acertada no mercado futuro ao preço CIF (cost of insurance and freight) como referência, o hedger deve preocupar-se em travar sua exposição não somente ao preço do ativo, mas também contra as variações dos custos de transporte da mesma. Os altos níveis dos fretes de transporte marítimo nas últimas décadas é um fator que tem acrescentado pressão de aumento nos preços das commodities, impactando assim, negativamente sobre os custos dos produtos importados de outros países. De acordo com o autor, contratos sobre fretes podem ser transacionados ou em mercados à vista, ou em mercados a termo através de FFA (forward freight agreement). O mercado de FFA é privado, por isso transações e sua natureza, não são disponibilizadas publicamente. No entanto, o crescimento do volume de negociações sobre esses contratos está aumentando consideravelmente nos últimos anos.

O risco de entrega relaciona-se à qualidade da commodity, para o qual não há como realizar um hedging financeiro. A única cobertura é fornecida por um contrato 
muito personalizado, ou por um longo e sólido relacionamento com o vendedor da mercadoria. Já o risco de crédito se caracteriza pelo fato de uma das partes do negócio, ou vendedor ou comprador, não honrar seu compromisso, e que é iminente do início ao final da realização da negociação.

\subsection{Relação entre Preço à Vista e Preço Futuro}

Os preços a termo e futuro negociados nos contratos, têm o benefício de fornecer indicações do preço à vista esperado para uma mercadoria no futuro e influenciar decisões sobre oferta, demanda e estocagem dessa no presente. Segundo Geman, os preços negociados nos mercados futuros, são indicativos altamente transparentes para comparação contra os atuais preços negociados por uma mercadoria no mercado à vista, pois a diferença entre eles é unicamente explicada por custos de transporte ou de estocagem, implícitos no custo de carregamento do produto.

Informações sobre preço à vista esperado são valiosas pelo fato de, no caso de commodities estocáveis, determinar a decisão de estocagem para firmas comerciais; alto preço futuro sinaliza a necessidade para uma maior estocagem e baixo preço futuro, aponta para uma redução no estoque atual. Refletindo expectativas sobre oferta e demanda futura, o preço futuro dispara decisões sobre estocagem, produção e consumo que re-aloca a oferta e demanda para uma commodity ao longo do tempo.

Para o autor, a teoria de estocagem objetiva explicar as diferenças entre o preço à vista e o preço futuro, analisando as razões pelas quais os agentes mantém estoques. Estoques têm um valor produtivo uma vez que permitem suprir demandas inesperadas, evitam o custo de freqüentes revisões na agenda de produção e eliminam a interrupção da manufatura. Esse benefício é apenas permitido ao possuidor do ativo e não do contrato derivativo e funciona como um contrato de opção embutido no ativo, o qual só é exercido em condições favoráveis do mercado.

Os trabalhos apresentados por Fama e French (1987) e Williams e Wright (1991) mostraram que o nível de estocagem de uma mercadoria tem uma relação 
direta e inversa com a volatilidade e o nível dos preços da mesma. Segundo esses autores, a variância dos preços decresce com o nível de estocagem do ativo e, no caso de ativos agrícolas, as volatilidades dos preços aumentam após o período de colheita e se mantém até a próxima. O trabalho de Geman e Nguyen (2002), além de abordar tal assunto, mostrou que em períodos de pré-colheitas, a volatilidade dos preços também é mais alta, diminuindo quando o resultado da mesma é conhecido.

A temperatura, a estiagem e a chuva, são fatores climáticos que têm papéis chave em todos os mercados de commodities agrícolas e, tem sido consistentemente os primeiros a explicar resultados e qualidades. De acordo com o autor, empresas agrícolas essencialmente tinham duas maneiras de fazer hedging contra esses fatores, que diretamente afetavam a volatilidade de suas receitas; ou através de um seguro-colheita por companhias estatais ou privadas ou tomar posição em contratos no mercado futuro. Entretanto, um recente instrumento criado no mercado, foi o contrato de derivativo de clima, que visam hedgear o risco contra fatores climáticos negativos.

\subsection{Ativos}

A escolha dos ativos utilizados para estudo nesse trabalho, foi baseada em sua relevância na economia do país, no caso dos agrícolas, e por serem elementos caracterizadores de tendências da economia mundial, no caso dos financeiros.

Os ativos agrícolas utilizados foram o açúcar cristal especial, álcool anidro carburante, café arábica e soja em grão a granel. Esses produtos são de grande importância na matriz de produção agrícola do país e muito relevantes na balança comercial do mesmo, quando considerado o volume de exportação sobre o total de exportação agrícola; além de serem negociados em grande volume no mercado futuro. Outra característica importante é que o açúcar, o café e a soja, são commodities negociadas mundialmente permitindo que a formação de preço e equilíbrios entre oferta e demanda, sejam organizados pelo mercado mundial. No caso dos produtos agrícolas analisados nesse trabalho, o Brasil tem enorme vantagem competitiva uma vez que, influenciado positivamente pelo clima, extensão da área produtiva e solo favorável, gera produtos com qualidade, com boa 
produtividade e com os menores custos de produção do mundo, principalmente no caso da cana-de-açúcar e da soja.

Os ativos financeiros utilizados foram o dólar comercial e o lbovespa. Esses ativos são de grande importância por serem indicadores de tendência da economia mundial. O dólar comercial americano é a moeda referência para cotações e comercializações de produtos no mundo. Dessa forma, a cotação do câmbio, que se refere ao número de unidades monetárias de um país que é necessário para trocar por uma unidade monetária dos Estados Unidos, é uma variável importante no fluxo da balança comercial de um país. Se a moeda do país estiver valorizada com relação à moeda americana, seus produtos podem se tornar caro e, consequentemente influenciar negativamente na exportação dos mesmos. $O$ Ibovespa é o indicador do fluxo de recursos do mercado de capitais mundial com relação ao brasileiro. À medida que investidores e especuladores estrangeiros encontram um ambiente econômico estável e oportunidades de investimentos com retornos atrativos no Brasil, há entrada de capitais no país em busca desses investimentos. Como o fluxo de recursos ou divisas no país é referenciada em dólar americano, ocorrendo maior fluxo de entrada de capitais, ocorre consequentemente valorização da moeda nacional e conseqüentemente, valorização do câmbio, influenciando diretamente na balança comercial, encarecendo os produtos nacionais.

\subsubsection{A Cana-de-Açúcar}

Segundo Vian (2003, p. 62-98), a cultura de cana-de-açúcar no Brasil desenvolveu-se inicialmente na região nordeste do país, apenas perdendo a hegemonia para a região centro-sul do em meados do século $X X$.

Desde o período colonial quando iniciou seu cultivo, essa cultura foi marcada por intensa intervenção Estatal cujo objetivo era viabilizar um ambiente econômico benéfico aos produtores paulistas e nordestinos, que permitisse a manutenção do sistema de produção. As políticas intervencionistas sempre tiveram o objetivo de garantir aos produtores bons preços para seus produtos e uma boa inserção desses no mercado externo. Entretanto, essas políticas não conseguiam eliminar os 
conflitos entre os produtores e os comerciantes e refinadores do produto, pois esses ao mesmo tempo em que financiavam os produtores fazendo adiantamento em elevadas quantias monetárias para início da safra, especulavam sobre os estoques e sobre as diferenças entre os períodos de safra do sudeste e do nordeste.

A produção açucareira nacional passou por momentos muito delicados no final do século XIX, sendo necessário uma forte modernização no setor para conseguir enfrentar a concorrência internacional com outros produtores. O processo de modernização baseava-se na tentativa de separação entre as atividades do cultivo e do processamento industrial da cana-de-açúcar. Dessa forma os produtores poderiam investir na melhoria de seus canaviais, enquanto que os investimentos com melhorias na produtividade industrial ficariam com outros grupos econômicos, surgindo novas unidades industriais chamadas de Engenhos Centrais. O financiamento para criação dessas novas unidades industriais, também foi marcado por intervenção econômica Estatal, por meio de leis que concediam financiamentos com juros subsidiados ao capital estrangeiro.

De acordo com Vian, os Engenhos Centrais não deram certo no nordeste, pois a utilização de máquinas e equipamentos de segunda mão, impediu que a produtividade aumentasse. Outro fator foi que a intervenção do capital estrangeiro fez com que os antigos Senhores de Engenho, perdessem poderio no controle da totalidade do processo produtivo da cana-de-açúcar dessas novas unidades, o que não foi aceito por eles, pois isso era a base de seu poder político. Dessa forma, essa fase de modernização não foi muito bem sucedida, surgindo posteriormente uma nova configuração do complexo canavieiro, tendo como os senhores de engenho detendo novamente o poder da produção, no entanto, marcado por uma nova e intensa intervenção do Estado no setor, criando leis e decretos e financiamentos subsidiados, para permitir um ambiente econômico favorável para o desenvolvimento da cultura. Surgiram-se então, novas unidades denominadas de Usinas, que beneficiavam de empréstimos governamentais, não só para a implantação de novas unidades fabris, mas também para aquisição de terras, para o plantio da lavoura e obras para a infra-estrutura necessária. 
No entanto, a configuração do complexo canavieiro sobre a estrutura do Engenho Central foi favorável na região centro-sul do país, mais especificamente na região sudeste, frente à tentativa de manutenção do antigo sistema dos senhores de engenho, pelas usinas, no nordeste. Isso permitiu, ao longo do tempo, a mudança da importância regional desse setor da região nordeste para o sudeste.

A característica da intervenção Estatal foi definitivamente marcante e direta entre 1931 e 1990, com a criação do Instituto do Açúcar e do Álcool (IAA), com objetivo de criar um "ambiente institucional" para amenizar conflitos de interesses e desenvolvimento do setor. Vian afirma que uma das primeiras ações governamentais junto ao setor, foi o incentivo ao uso alternativo da cana-de-açúcar para a produção de álcool e a formação de estoques reguladores de açúcar para o mercado interno. Essa alternativa de utilização da cana-de-açúcar para a produção de álcool foi adotada em meados de 1970, dando origem ao Programa Nacional do Álcool ou Proálcool em 1975, com o objetivo de economizar divisas com a importação do petróleo, e inaugurando uma nova fase de expansão do complexo sucroalcooleiro nacional.

Contudo, no início dos anos 90, as características estruturais básicas do complexo canavieiro brasileiro, podiam ser resumidas em: produção agrícola e fabril sob controle dos usineiros, heterogeneidade produtiva, baixo aproveitamento de subprodutos, competitividade fundamentada, em grande medida, nos baixos salários e na expansão extensiva e com enormes diferenças entre os pólos produtivos da região nordeste e sudeste. No entanto, o principal fato da década de 90 , foi à desregulamentação do complexo, que fez parte de um amplo processo de afastamento do Estado da economia brasileira, e tentativas posteriores de autoregulação, que culminaram com a consolidação da União da Agroindústria Canavieira de São Paulo (ÚNICA), destacando-se como principal entidade representativa desse estado e pelo lado comercial, a criação de grupos de comercialização do álcool.

Analisando o complexo canavieiro sob a ótica da cadeia produtiva, as diversas peculiaridades existentes nela, tornam muito difícil que o equilíbrio entre oferta e demanda em ambiente de livre mercado seja atingido e, segundo Moraes e 
Shikida (2002, p. 27), reforçam a necessidade do desenvolvimento de um modelo de gestão, que associe ações públicas e privadas, de modo a assegurar a estabilidade dos principais produtos: cana-de-açúcar, açúcar, álcool hidratado e álcool anidro, além da recente energia elétrica co-gerada pela queima do bagaço e da palha de cana.

Segundo os autores, a primeira característica dessa cadeia produtiva é que o principal insumo, que é a cana-de-açúcar, é de origem agrícola, portanto, está sujeita aos riscos climáticos e fitossanitários, a sazonalidade da produção e à variação de renda dos produtores. Dessa forma, a oferta de cana-de-açúcar, pode sofrer variações inesperadas e assim incorrer em importantes variações nos preços dos subprodutos e também no abastecimento dos mesmos no mercado. O açúcar, por ser uma commodity internacional, é disponível no mercado mundial em quantidades suficientes para regular o mercado na falta do produto, o mesmo não acontece com o álcool combustível.

Uma característica da cana-de-açúcar é que é uma cultura de ciclo longo, sendo necessários no mínimo cinco cortes, para que o canavial se torne viável economicamente. Dessa forma, essa cultura requer um planejamento de longo prazo, para variações de demanda de curto prazo, o que pode da mesma forma dificultar a oferta adequada dos canaviais. Esse fato faz com que haja uma intensa coordenação de toda a cadeia produtiva, não somente das unidades industriais, mas também dos fornecedores do insumo.

Outra característica que diferencia essa cadeia das demais e que torna bastante complexo seu funcionamento com ausência completa do governo e sem um modelo de gestão é a flexibilidade de produzir produtos ligados a mercados tão distintos, como açúcar, álcool e energia elétrica, embora esse último produto possa ser considerado um subproduto da produção de álcool ou de açúcar. Essa interligação faz com que o equilíbrio simultâneo entre esses mercados, dificilmente ocorra em um ambiente de livre mercado. A decisão de produzir álcool anidro, álcool hidratado e açúcar é, atualmente, tomada no setor privado, que considera como variável de decisão, os preços relativos entre esse produtos. 
Outro fator que dificulta a adequação da oferta à demanda em um ambiente de livre mercado, é a limitação individual das unidades fabris à flexibilidade da produção, dada à capacidade instalada. Assim, a decisão de oferta torna-se bastante complexa ao envolver diversos mercados que interagem simultaneamente e se comunicam. De acordo com o autor, nota-se que a oferta de cana depende das expectativas formadas sobre o seu preço de outras culturas, pois pode causar o redirecionamento de produção para um produto economicamente mais favorável, além das condições climáticas ao longo da safra. Em relação à demanda pela cana, é derivada pelas demandas existentes pelo açúcar e álcool.

Com relação ao mercado de açúcar, certamente esse depende da adequação da oferta à demanda pelo produto, e essa oferta, depende dos preços relativos entre o açúcar (mercado interno e externo) e álcool. Por sua vez a demanda de açúcar, depende da renda da população, da existência de produtos substitutos e das políticas protecionistas dos países importadores. Alterações em qualquer dessas variáveis, deslocam a oferta e/ou a demanda de açúcar, com alteração no equilíbrio de outros mercados, álcool e cana-de-açúcar.

Apesar das questões peculiares que envolvem esse mercado, o Brasil tem, atualmente, grande destaque com relação à vantagem competitiva mundial, destacando-se como o primeiro em produção, exportação e menor custo de produção, como pode ser observado pela tabela 1 e pelo gráfico 1.

Tabela 1 - Maiores países produtores e exportadores de açúcar no mundo

\begin{tabular}{|c|c|c|c|c|}
\hline $2006 / 07$ & $\begin{array}{c}\text { Produção } \\
\text { (milhões de ton.) }\end{array}$ & $\begin{array}{c}\text { Exportação } \\
\text { (milhões de ton.) }\end{array}$ & População (milhões) & $\begin{array}{c}\text { Consumo per capita } \\
(\mathrm{Kg})\end{array}$ \\
\hline Brasil & 33.591 & $22.200\left[1^{\circ}\right]$ & 188 & 56 \\
\hline India & 27.174 & $1.341\left[6^{\circ}\right]$ & 1117 & 20 \\
\hline EU & 16.762 & $1.228\left[7^{\circ}\right]$ & 457 & 42 \\
\hline China & 11.630 & - & 1314 & 10 \\
\hline Estados Unidos & 7.661 & - & 298 & 32 \\
\hline Tailândia & 7.011 & $4.528\left[2^{\circ}\right]$ & 65 & 39 \\
\hline Mexico & 5.543 & $380\left[12^{\circ}\right]$ & 107 & 52 \\
\hline SADC & 5.419 & $2.339\left[4^{\circ}\right]$ & 157 & 23 \\
\hline Australia & 5.156 & $3.958\left[3^{\circ}\right]$ & 20 & 50 \\
\hline Paquistão & 3.813 & - & 166 & 25 \\
\hline
\end{tabular}

Fonte: illovosugar 


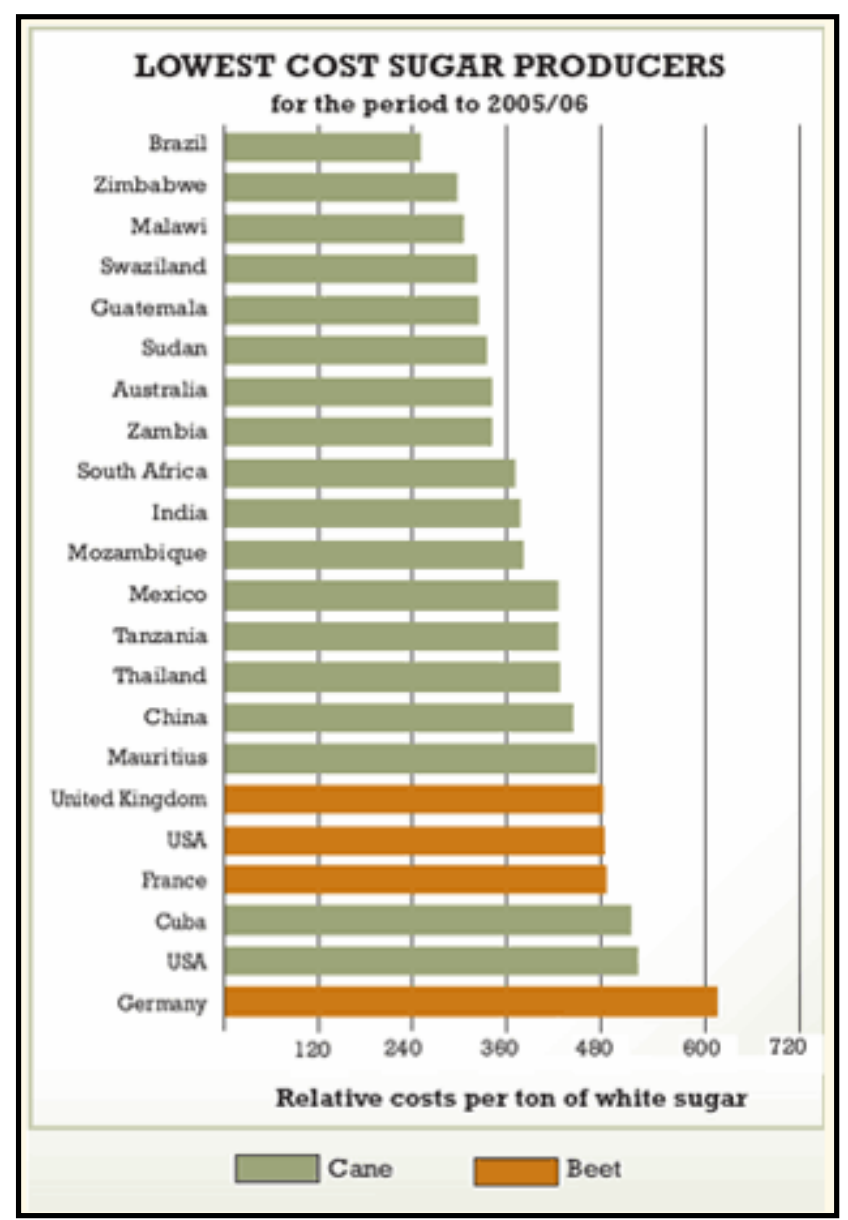

Gráfico 1 - Produtores de açúcar com menores custos no mundo Fonte: Illovosugar

O álcool combustível proveniente da cana-de-açúcar, apesar de ainda não ser uma commodity internacionalmente negociada, está tendo um grande apelo mundial para isso. A partir da assinatura do Protocolo de Kyoto em 1997, no qual países industrializados e grandes emissores $\mathrm{CO}_{2}$ propuseram a reduzir seus volumes de emissão desse gás, iniciou-se a busca por combustíveis alternativos aos derivados de petróleo, que emitam menor quantidade desse gás em sua queima. Nesse âmbito o álcool combustível, que pode ser obtido da cana-de-açúcar, do milho, da beterraba, do trigo, dentre outros, surge como principal alternativa. O Brasil tem grande vantagem na produção via cana-de-açúcar por ser pioneiro no conhecimento da tecnologia de produção e por apresentar o menor custo de produção mundial.

\subsubsection{O Café}


A cultura do café teve sua propulsão incentivada pela estagnação da cultura da cana-de-açúcar a partir da segunda metade do século XX. Nessa época, o açúcar, que era o principal produto exportado pelo Brasil, perdeu concorrência para as outras regiões produtoras no mundo, que ofereciam um produto de melhor qualidade e com preços mais baixos. O café surge então como um produto de melhor qualidade, menor custo de produção e rentabilidade muito superior à canade-açúcar. Isso permitiu que ele se tornasse, na época, o principal produto exportado pelo país e futuramente teve grande papel como um importante instrumento para o financiamento do crescimento do Brasil, viabilizando divisas para o início do processo de industrialização do país.

Segundo estudo da Unicamp-IE-NEIT (2002, p.2), a cultura do café caracteriza por empregar um grande número de pessoas, sendo um dos setores com maior capacidade de geração de empregos no país pela complexidade de sua cadeia produtiva, demandando mão-de-obra qualificada e não qualificada. No entanto, esse setor, assim como a cana-de-açúcar, foi marcado historicamente por intervencionismo Estatal, regulamentando o setor com relação à oferta e produção do produto e políticas internacionais.

Da cadeia produtiva do café originam-se, basicamente, três produtos: o café verde (arábica e robusta), o café torrado e moído e o café solúvel. Os fatores relevantes e tradicionais que determinam à competitividade de um produto e suas vantagens comparativas com outros produtores são produtividade e custo. Com relação a esses fatores, o Brasil tornou-se referência mundial nessa cultura. Em se tratando do café verde, no quesito produtividade, é importante diferenciar a competitividade do café robusta e do café arábica. No caso do café robusta, segundo o relatório da Unicamp, o Vietnã, supera o Brasil em produtividade e em custo de produção; no entanto, no que se refere ao arábica, o Brasil possui produtividade média semelhante à Colômbia. Esses países, juntamente com o Brasil, fazem para do grupo de elite que lideram o mercado mundial de produção de café verde, como pode ser observado pela tabela 2 . 
Tabela 2 - Produção Mundial de Café por país (volume em mil sacas de $60 \mathrm{~kg}$ )

\begin{tabular}{|c|c|c|c|c|c|c|c|c|}
\hline País Período & 2007 & 2006 & 2005 & 2004 & 2003 & 2002 & 2001 & 2000 \\
\hline Brasil & 33.740 & 42.512 & 32.944 & 39.272 & 28.820 & 48.480 & 31.300 & 31.100 \\
\hline Vietnã & 15.950 & 18.455 & 13.595 & 14.174 & 15.231 & 11.555 & 13.133 & 14.775 \\
\hline Colômbia & 12.400 & 12.789 & 12.329 & 12.033 & 11.197 & 11.889 & 11.999 & 10.532 \\
\hline Indonésia & 7.000 & 6.650 & 8.659 & 7.536 & 6.571 & 6.785 & 6.833 & 6.978 \\
\hline Etiópia & 5.733 & 4.636 & 4.003 & 4.568 & 3.874 & 3.693 & 3.756 & 2.768 \\
\hline Índia & 4.850 & 4.750 & 4.567 & 4.592 & 4.508 & 4.588 & 4.970 & 4.526 \\
\hline México & 4.350 & 4.200 & 4.225 & 3.867 & 4.200 & 4.350 & 4.200 & 4.815 \\
\hline Guatemala & 4.000 & 3.950 & 3.676 & 3.703 & 3.610 & 4.070 & 3.669 & 4.940 \\
\hline Peru & 3.190 & 4.250 & 2.419 & 3.355 & 2.616 & 2.900 & 2.749 & 2.596 \\
\hline Honduras & 3.500 & 3.461 & 3.204 & 2.575 & 2.968 & 2.496 & - & - \\
\hline Costa do Marfim & 2.350 & 2.482 & 2.369 & 2.301 & 2.689 & 3.145 & 3.595 & 4.846 \\
\hline El Salvador & 1.476 & 1.372 & 1.502 & 1.437 & 1.477 & 1.438 & 1.667 & - \\
\hline Nicaragua & 1.750 & 1.300 & 1.718 & 1.130 & 1.547 & 1.200 & 1.116 & - \\
\hline Outros países & 16.743 & 15.423 & 15.569 & 16.352 & 16.289 & 17.027 & 19.101 & 24.807 \\
\hline TOTAL & 117.032 & 126.230 & 110.806 & 116.895 & 105.597 & 123.616 & 108.088 & 112.683 \\
\hline
\end{tabular}

Fonte: MAPA/SPAE/CONAB, OIC

No caso do café robusta, o custo é uma variável muito importante na determinação do preço final desse produto, por ele se tratar de um café menos valorizado e destinado à confecção do café solúvel, dificultando a inserção da produção brasileiro no mercado mundial. Já no café arábica, o Brasil desponta, entre os maiores produtores, como o de menor custo de produção e com boa produtividade, conseguindo a manutenção e crescimento da participação no mercado mundial. No entanto, considerando o mercado internacional, o Brasil é tido como um fornecedor de quantidade, ao passo que países como Colômbia, Guatemala, Costa Rica e Quênia, são países fornecedores de qualidade. Isto posto, - Brasil, passou a empenhar-se a mostrar que além de quantidade, seus grãos possuem também qualidade para ganhar mercado nos principais mercados consumidores, Estados Unidos e Europa.

A indústria de café solúvel no Brasil é praticamente toda voltada para o mercado externo e foi implantada e desenvolvida no país nos anos 60 , mediante incentivos governamentais, com o propósito de escoar o excesso de estoque de café de qualidade inferior. A produção desse café exige uma planta fabril mais sofisticada, exigindo uma indústria mais concentrada, associada a canais de distribuição e adequação do blend do produto à demanda. Segundo o relatório da Unicamp, a expansão dessa indústria depara-se com quatro entraves: a) aumento do spread entre os preços do café robusta no mercado interno e externo, decorrente 
do aumento da produção desse café na Ásia e problemas climáticos nas regiões produtoras do Brasil; b) barreiras tarifárias, afetando a indústria brasileira, enquanto que indústrias de países concorrentes, são isentos; c) questões tributárias; e d) tecnologia.

Ao contrário da indústria de café solúvel, a de torrefação e moagem é totalmente voltada para o mercado interno. Essa indústria caracteriza-se por não apresentar barreiras de entradas de novas firmas, uma vez que não há fortes restrições tecnológicas e o capital mínimo exigido é baixo, quando comparado com outros setores industriais; caracterizando-se, portanto, uma indústria muito competitiva, que muitas vezes passa por deslealdade, como sonegação de impostos e adulteração do produto final.

As empresas multinacionais têm sido atraídas para essa indústria, tendo em vista a estabilidade e crescimento da econômica, fazendo com que a melhoria de renda permita maior consumo e com mais freqüência desse tipo de produto. Outro motivo favorável às empresas multinacionais é a facilidade de estar junto do mercado produtor da matéria-prima, já que são grandes compradoras de café verde. Com relação à exportação desse produto, ela é ainda bastante restrita, tendo um volume pouco relevante.

Analisando a relevância do café também em negociações no âmbito de bolsa de mercadorias, observa-se que dentre os contratos de derivativos agrícolas negociados no Brasil nos últimos 7 anos, os de café arábica foram o de maior relevância, perdendo a liderança para os contratos de boi gordo, apenas no ano de 2007, quando considerado o total de contratos agrícolas negociados, conforme pode ser observado pelo gráfico 2 . 


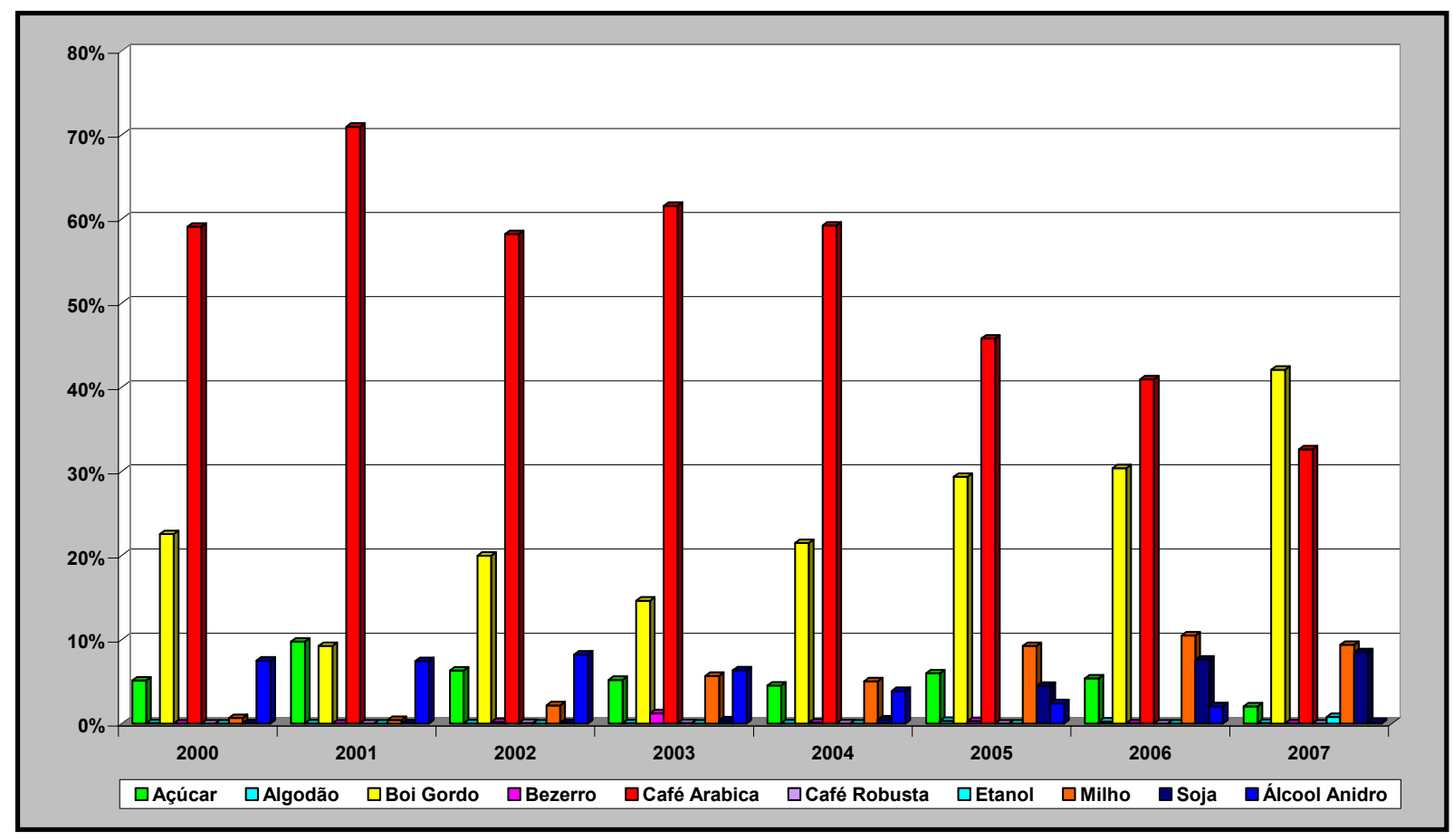
produto

Gráfico 2 - Proporção de contratos agrícolas negociados anualmente entre 2000 e 2007 - por Fonte: BM\&F

\subsubsection{A Soja}

A cultura da soja iniciou-se no Brasil no final do século XIX, quando foram trazidos dos Estados Unidos alguns cultivares para realização de pesquisa. Como afirma Siqueira (2004, p. 129) no final do século $X X$, foram realizadas as primeiras plantações em São Paulo e Rio Grande do Sul, passando assim a ser cultivada em grande escala no sul e sudeste e, mais tarde, na região central-oeste e nordeste do país. A partir de então, a cultura desse grão tomou proporções tão expressivas, que seu impacto na economia do país, segundo o autor, pode ser comparado com a expressividade da cultura da cana-de-açúcar (século XIV) e café (século XIX). O reflexo desse impacto pode ser observado na tabela 3 que mostra o Brasil como o segundo maior produtor de soja no mundo, nos últimos quatro anos. 
Tabela 3 - Principais países produtores de soja do mundo (volume em 1.000 toneladas)

\begin{tabular}{lcccc}
\hline País Período & $\mathbf{2 0 0 3 / 0 4}$ & $\mathbf{2 0 0 4 / 0 5}$ & $\mathbf{2 0 0 5 / 0 6}$ & $\mathbf{2 0 0 6 / 0 7}$ \\
\hline Estados Unidos & 66.778 & 85.013 & 83.368 & 86.770 \\
Brasil & 51.000 & 53.000 & 57.000 & 59.000 \\
Argentina & 33.000 & 39.000 & 40.500 & 48.800 \\
República da China & 15.394 & 17.400 & 16.350 & 15.967 \\
India & 6.800 & 5.850 & 7.000 & 7.690 \\
Paraguai & 3.911 & 4.040 & 3.640 & 6.200 \\
Canadá & 2.263 & 3.042 & 3.161 & 3.460 \\
Outros & 7.458 & 8.406 & 9.518 & 9.367 \\
\hline Total & 186.604 & 215.751 & 220.537 & 237.254 \\
\hline
\end{tabular}

Fonte: USDA

Além de destaque na produção mundial, o Brasil também ocupa destaque na exportação, ocupando também a segunda posição como pode ser observado pela tabela 4, perdendo a liderança apenas para os Estados Unidos.

Tabela 4 - Principais países exportadores de soja no mundo (volume em 1.000 toneladas)

\begin{tabular}{|c|c|c|c|c|c|}
\hline $\begin{array}{ll}\text { País } & \text { Período } \\
\end{array}$ & $2003 / 04$ & $2004 / 05$ & $2005 / 06$ & $2006 / 07$ & $2007 / 08 e^{*}$ \\
\hline Estados Unidos & 24.128 & 29.860 & 25.579 & 30.428 & 28.577 \\
\hline Brasil & 20.417 & 20.137 & 25.911 & 23.485 & 27.344 \\
\hline Argentina & 6.741 & 9.568 & 7.249 & 9.538 & 11.500 \\
\hline Paraguai & 2.776 & 2.888 & 2.465 & 4.000 & 4.600 \\
\hline Canadá & 897 & 1.093 & 1.326 & 1.683 & 1.495 \\
\hline Outros & 1.228 & 1.197 & 1.411 & 1.788 & 1.543 \\
\hline Total & 56.187 & 64.743 & 63.941 & 70.922 & 75.059 \\
\hline
\end{tabular}

Fonte: USDA

Entretanto, como afirma Siqueira (2004, p. 129), dado o potencial de expansão que ainda existe dessa lavoura no Brasil, estima-se que o país ainda está apenas na metade do potencial produtivo dessa cultura. Dessa forma, a expectativa de crescimento de produção e exportação futura desse produto, poderia colocar o país na liderança desses dois quesitos.

A utilização da soja é bastante diversificada indo de alimentos, passando por cosméticos, farmacêuticos até pecuária, como uma importante fonte de nutriente na composição da alimentação animal. Segundo o autor, apesar de sua riqueza nutricional e um preço bastante acessível é um produto pouco consumido 
mundialmente para alimentação humana, sendo mais utilizado para alimentação animal. Variáveis que são importantes na expectativa de aumento da demanda mundial por esse produto, estão ligadas diretamente à maior inserção dele na cultura da alimentação humana, indiretamente pelo aumento de consumo de carne e diretamente no aumento da utilização de biodiesel que utilizam o óleo de soja como insumos na sua produção. A forma de consumo direto da soja se dá, basicamente, através de grãos, do óleo, que é a principal maneira e do farelo; e indiretamente através de outros produtos que a utilizam como ingrediente.

De acordo com Siqueira, a produtividade da cultura da soja no mundo, experimentou uma expressiva melhoria entre o período de 1961 a 2003, resultante de avanços tecnológicos em genética, máquinas e implementos agrícolas e técnicas agrícolas; abrangendo desde o plantio à colheita, implicando também em menores perdas do produto. Nesse ponto, um fator favorável foi a utilização da soja transgênica, que segundo o autor, atualmente estimada em $50 \%$ da produção mundial, permitiu tais avanços. No caso do Brasil, esses avanços tecnológicos, foram implantados principalmente na região centro-oeste que, atualmente, é a região de maior produtividade e com menor custo de produção no país, conseguindo colocar maiores quantidades do produto no mercado internacional, a preços mais competitivos. No entanto, Siqueira afirma que, apesar dessas melhorias extremamente significativas, para que o país mantenha, ou melhore, sua posição tanto em produção quanto em exportação, são necessárias iniciativas que proporcionem a elevação da competitividade dos pólos produtores brasileiros por meio do apoio à implantação de projetos empresariais bem estruturados com produtividades elevadas e a realização de melhorias na infra-estrutura de transportes com objetivo de permitir o escoamento eficiente das áreas das safras até os grandes centros consumidores; além dos produtores atenderem às condições fitossanitárias internacionais.

Analisando a importância da soja sob a ótica da matriz de produtos agrícolas exportados pelo Brasil nota-se, pelo gráfico 3, que a soja foi a que apresentou liderança dentre o total de produtos agrícolas exportados pelo país nós últimos 7 anos. 


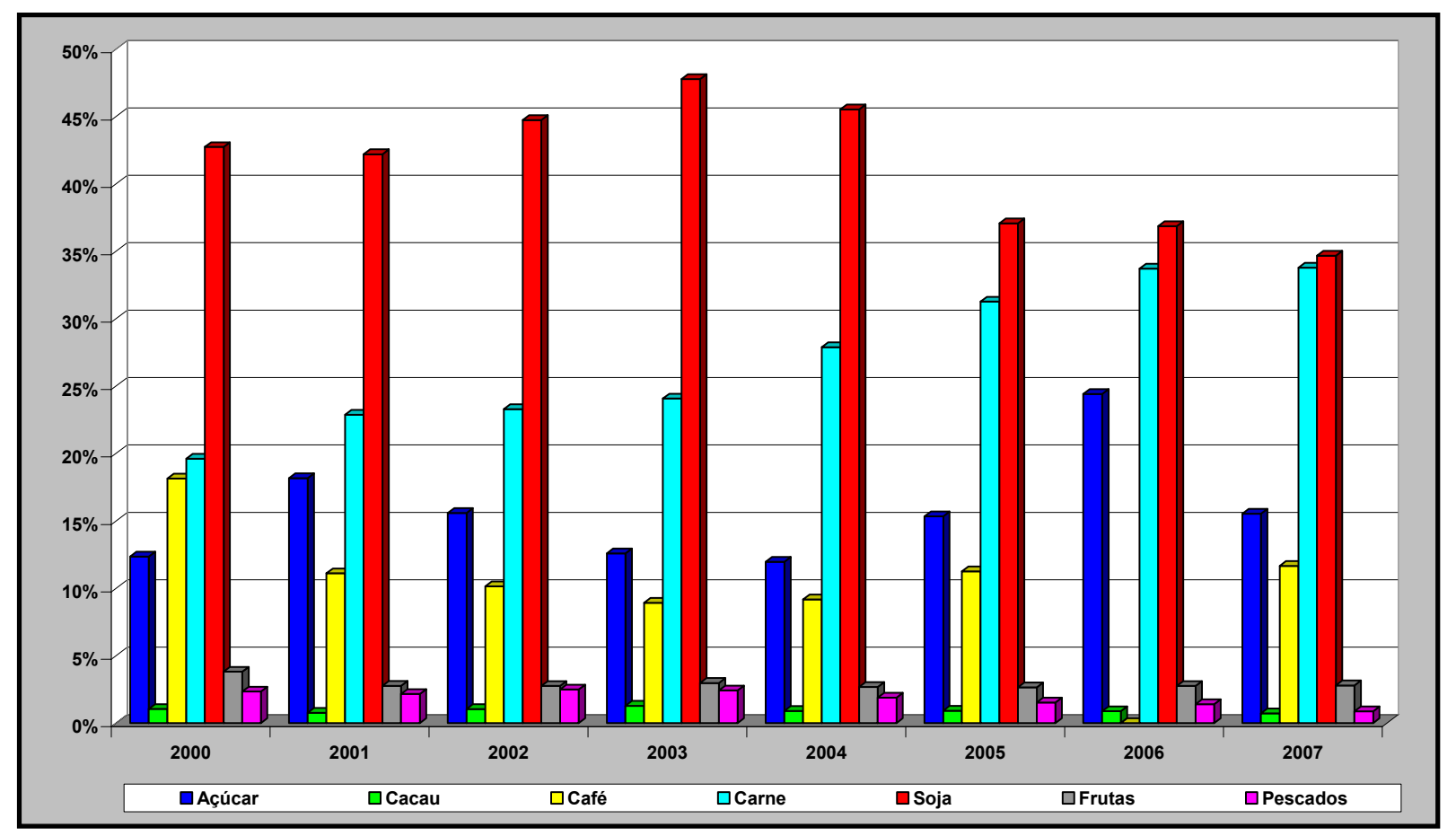

Gráfico 3 - Exportação anual por produto agropecuário entre 2000 e 2007 Fonte: Ministério da Indústria, Desenvolvimento e Comércio Exterior.

\subsubsection{O Dólar Comercial e o lbovespa}

O dólar comercial é o fator mundialmente utilizado como relação de troca entre mercadorias de um país com as de outros países do mundo. Esse fator indica quando da moeda nacional é necessária para adquirir uma unidade da moeda americana. Dessa forma, a valorização da moeda nacional de um país, frente essa moeda, indica que é necessária mais moeda americana, para adquirir uma mercadoria nesse país. Considerando que o Brasil é um país tradicional em produção e exportação agrícola, a qual tem grande relevância na balança comercial do país, a valorização do câmbio, tem impacto direto e significativo na economia do país.

A bolsa de valores de São Paulo, cujo índice representativo é o lbovespa, é um termômetro muito significativo para medir a entrada de capitais estrangeiros no país. Atualmente, com o mercado financeiro globalizado, o fluxo de capitais pelo mundo é constante. Como a economia brasileira, vem constantemente apresentando bons índices e um ambiente cada vez menos arriscado para investimentos, a 
entrada de capitais tanto especulativos quando para investimentos de longo prazo no país é bastante considerável em volume. Esses capitais são referenciados em dólar americano e intitulados como divisas. Com o grande volume de entrada de divisas no país, a oferta de moeda americana torna-se mais abundante que a moeda nacional, desvalorizando a moeda americana e consequentemente, valorizando a moeda nacional, impactando diretamente na balança comercial do país, pois os produtos exportados tornam-se mais caros. 


\section{FUNDAMENTAÇÃO TEÓRICA}

\subsection{Medidas de Retorno}

O retorno total de um ativo depende do aumento ou do decréscimo do seu preço, durante o período de investimento. A caracterização de ganho ou perda de capital é usualmente representada pela porcentagem ou pela taxa de retorno, por ser uma medida independente do montante investido e livre de escala.

\subsubsection{Retorno Discreto}

A mensuração da taxa de retorno discreto é comum na literatura referente a finanças. Sendo $P_{t_{0}}$ o preço de um ativo em $t_{0}, P_{t_{1}}$ o preço desse ativo em $t_{1} e$ $\Delta \mathrm{P}=\mathrm{P}_{\mathrm{t}_{1}}-\mathrm{P}_{\mathrm{t}_{0}}$ a variação do preço do ativo entre $\mathrm{t}_{0}$ e $\mathrm{t}_{1}$; a variação relativa do preço entre $t_{0}$ e $t_{1}$ ou o retorno líquido simples desse ativo nesse intervalo, é definido por:

$$
\mathrm{R}_{\mathrm{t}}=\frac{\mathrm{P}_{\mathrm{t}_{1}}-\mathrm{P}_{\mathrm{t}_{0}}}{\mathrm{P}_{\mathrm{t}_{0}}}=\frac{\Delta \mathrm{P}}{\mathrm{P}_{\mathrm{t}_{0}}}
$$

Da equação (3.1), obtem-se a relação $1+\mathrm{R}_{\mathrm{t}}=\frac{\mathrm{P}_{\mathrm{t}_{1}}}{\mathrm{P}_{\mathrm{t}_{0}}}$, chamada de retorno bruto simples, em que, usualmente, $\mathrm{R}_{\mathrm{t}}$ é expresso em porcentagem relativa ao período, também chamada de taxa de retorno.

\subsubsection{Retorno Contínuo}


Dado que $\mathrm{P}_{\mathrm{t}_{0}}$ seja o preço do ativo em $\mathrm{t}_{0} \mathrm{e}, \mathrm{P}_{\mathrm{t}_{1}}$ o preço do ativo em $\mathrm{t}_{1}$, define-se o retorno composto continuamente ou o retorno logarítmico, como:

$$
r_{t}=\ln \left(\frac{P_{t_{1}}}{P_{t_{0}}}\right)=\ln \left(1+R_{t}\right)
$$

\subsubsection{Retorno sobre um Portfólio}

O retorno é uma variável quantitativa à qual se pode associar um modelo probabilístico, caracterizando-se uma variável aleatória. A variável aleatória retorno pode assumir $n$ valores cada qual associado uma probabilidade de ocorrência. Duas medidas importantes são empregadas no mercado de capitais para caracterizar uma variável aleatória: a média, $\mu$, e a variância $\sigma^{2}$.

Sharpe et al. (1998, p.151), definem portfólio como sendo um ativo formado de outros $n$ ativos, sendo $w$ a ponderação de cada ativo neste portfólio. Dessa forma, o retorno sobre um portfólio de ativos, é dado por:

$$
\mathrm{R}_{\mathrm{pj}}=\sum_{\mathrm{i}=1}^{\mathrm{n}}\left(\mathrm{w}_{\mathrm{i}} \mathrm{R}_{\mathrm{ij}}\right)
$$

Em que:

$R_{p j}:$ j-ésimo retorno do portfólio;

$\mathrm{R}_{\mathrm{ij}}$ : j-ésimo retorno do ativo i;

$\mathrm{w}_{\mathrm{i}}$ : proporção do ativo no portfólio;

$\sum \mathrm{w}_{\mathrm{i}}=1$.

Dado que o retorno do portfólio é uma variável aleatória, o retorno médio, ou esperado, deste portfólio é dado por: 


$$
E\left(R_{p}\right)=E\left(\sum_{i=1}^{n} w_{i} R_{i j}\right)
$$

Em que:

$\mathrm{E}\left(\mathrm{R}_{\mathrm{p}}\right)$ : retorno médio do portfólio.

\subsection{Medidas de Risco}

Bodie et al. (2003, p.135) afirmam que qualquer investimento envolve algum grau de incerteza sobre seus retornos futuros. As fontes de risco sobre investimentos originam desde flutuações macroeconômicas a variações sobre patrimônios das empresas, a ações inesperadas sobre ativos específicos, entre outros.

Conforme afirmam Solomon e Pringle (1981) e Gitman (1984), respectivamente, risco pode ser definido como a possibilidade de perda ou o grau de incerteza a respeito da ocorrência de um evento. Dentre as diferentes medidas de risco, a variância é bastante utilizada por caracterizar através de um número, a dispersão de um conjunto de dados ou de uma distribuição de probabilidade de uma variável aleatória.

\subsubsection{Variância dos Retornos sobre o Portfólio}

A variância dos retornos sobre um portfólio de ativos, é dada por:

$$
\sigma^{2}\left(R_{p}\right)=E\left[R_{p}-E\left(R_{p}\right)\right]^{2}
$$

Em que:

$\sigma^{2}\left(R_{p}\right)$ : variância dos retornos do portfólio; 
$\mathrm{R}_{\mathrm{p}}$ : retorno do portfólio;

$\mathrm{E}\left(\mathrm{R}_{\mathrm{p}}\right)$ : valor médio dos retornos do portfólio.

\subsubsection{Coeficiente de Gini}

O coeficiente de Gini é uma medida de dispersão, desenvolvida em 1912, pelo e-statístico italiano Corrado Gini, cuja finalidade era mensurar desigualdade de renda. Dorfman (1979) demonstra duas formas de derivação desse coeficiente: uma pela curva de Lorenz e outra pela medida da variabilidade de qualquer distribuição estatística ou distribuição de probabilidade, como originalmente apresentada por Gini.

Segundo Dorfman (op. cit., p.149), o coeficiente de Gini pode ser definido sobre uma medida de variabilidade, ou dispersão, de uma variável aleatória. Essa medida é dada pelo valor médio, ou esperado, da diferença absoluta entre todos os pares de observações dessa variável em uma distribuição. Dessa forma, o coeficiente de Gini, é dado por:

$$
\mathrm{G}=\frac{\mathrm{E}|\mathrm{x}-\mathrm{y}|}{2 \mu}
$$

Em que:

$\mathrm{E}|\mathrm{x}-\mathrm{y}|$ : diferença média de Gini;

$\mu$ : valor médio da variável aleatória.

Supondo $x$ e $y$ independentes e identicamente distribuídos e, considerando $\mathrm{F}(\mathrm{x})$ e $\mathrm{F}(\mathrm{y})$ suas funções de distribuição acumulada, a diferença média de Gini, pode também ser definida como:

$$
E|x-y|=\int_{-\infty}^{+\infty} \int_{-\infty}^{+\infty}|x-y| d F(x) d F(y)
$$

Em que: 
$\mathrm{F}(\mathrm{x})$ : função de distribuição acumulada de $\mathrm{x}$;

$\mathrm{F}(\mathrm{y})$ : função de distribuição acumulada de $\mathrm{y}$.

Yitzhaki (1982, p.180) apresentando as condições necessárias para dominância estocástica ${ }^{5}$, define a diferença média do coeficiente de Gini como $\Gamma$, em que $\Gamma=\frac{E|x-y|}{2}$. O autor, em 1983, apresenta um trabalho, no qual incorpora à $\Gamma$ um parâmetro que reflete o nível de aversão ao risco do indivíduo, considerando uma extensão à definição da diferença média de Gini, denominado coeficiente de Gini estendido, ou apenas Gini estendido.

Como proposto por Yitzhaki, substituindo $|x-y|=2\left[\left(\frac{x+y}{2}\right)-\min (x, y)\right]$ em $\Gamma$, determina-se a seguinte expressão:

$$
\Gamma=\int_{a}^{b}[1-F(x)] d x-\int_{a}^{b}[1-F(x)]^{v} d x
$$

Em que:

$\Gamma$ : coeficiente de Gini estendido;

$\mathrm{F}(\mathrm{x})$ : função de distribuição acumulada de $\mathrm{x}$;

$v$ : parâmetro de aversão ao risco, de tal forma que:

$0 \leq v \leq 1$ : indivíduo propenso ao risco;

$\mathrm{v}=1$ : indivíduo neutro ao risco;

$v \geq 1$ : indivíduo avesso ao risco.

Shalit e Yitzhaki (1984) apresentaram um trabalho no qual utilizaram a definição do conceito de Gini estendido na variável aleatória retorno sobre um portfólio de ativos. Assim, $\Gamma$ pode ser considerada como uma medida de

\footnotetext{
${ }^{5}$ A definição de dominância estocástica é apresentada no apêndice.
} 
variabilidade, ou dispersão, dessa variável aleatória e usada como alternativa ao desvio-padrão, na caracterização de um portfólio sobre a estrutura risco e retorno.

Dessa forma, considerando o retorno do portfólio e $v$, o parâmetro que mede o grau de aversão ao risco do indivíduo tomador de decisão, $\Gamma$ pode ser definido como:

$$
\Gamma=\int_{a}^{b}\left[1-F\left(R_{p}\right)\right] d R_{p}-\int_{a}^{b}\left[1-F\left(R_{p}\right)\right] v d R_{p}
$$

Em que:

$\Gamma$ : coeficiente de Gini estendido;

$\mathrm{F}\left(\mathrm{R}_{\mathrm{p}}\right)$ : função de distribuição acumulada dos retornos do portfólio;

$\mathrm{R}_{\mathrm{p}}$ : retorno do portfólio.

Como afirmado por Shalit e Yitzhaki (op. cit., pag. 1.461) a equação (3.9), pode também ser representada por:

$$
\Gamma=-v \operatorname{cov}\left\{\mathrm{R}_{\mathrm{p}},\left[1-\mathrm{F}\left(\mathrm{R}_{\mathrm{p}}\right)\right]^{v-1}\right\}
$$

\subsection{Teoria do Portfólio}

A questão que envolve a seleção de um portfólio foi originalmente estudada e apresentada à literatura, por Harry M. Markowitz em 1952. Markowitz, apud Sharpe et al. (1998, p. 139), afirma que um investidor que detém determinado volume monetário, caracterizado como riqueza, e deseja realizar um investimento em um ativo ou portfólio por um determinado período de tempo, deve considerar que os retornos futuros desse ativo ou portfólio são desconhecidos. Por isso, esse investidor deveria estimar o retorno esperado de diferentes ativos ou portfólios, e investir no que apresentasse maior retorno esperado. Ele nota também que a decisão do investidor pode, muitas vezes, ser insensata, pois ao mesmo tempo em 
que este deseja obter o maior retorno, deseja também que seja o mais certo possível, buscando dessa forma, maximizar o retorno esperado e minimizar a incerteza, ou seja, o risco. Para Markowitz, todo investidor deveria basear suas decisões sobre duas medidas estatísticas, obtidas da variável aleatória taxa de retorno do ativo ou portfólio. Estas medidas são: o risco, determinado pelo desviopadrão, e o retorno esperado, determinado pela média da variável.

Segundo Sharpe, um portfólio se caracteriza por uma coleção de ativos. Assim, para o investidor selecionar um portfólio ótimo dentre os diferentes possíveis, deve-se escolher um portfólio com um determinado nível de risco.

Alguns autores procuraram definir os conceitos de risco e retorno, que norteiam as decisões de investimentos dos indivíduos, como apresentado anteriormente. Baseado em tais definições, um investidor racional fundamentará sua decisão, buscando sempre maximizar o retorno e minimizar o risco em seu investimento. Segundo Bodie et al. (2001, p.163), o processo de investimento consiste em duas tarefas: primeira a análise do mercado, quando se avaliam os riscos e os retornos esperados, atribuído a uma estrutura de possíveis ativos para investimentos; e segunda, a formação de um portfólio ótimo de ativos. Esta última envolve determinar a melhor oportunidade disponível para a estrutura risco-retorno, sob uma gama de possíveis portfólios para investimento.

Sharpe afirma que, duas suposições são implicitamente consideradas na discussão sobre seleção de portfólios, conforme apresentada por Markowitz. A suposição de não satisfação, onde os indivíduos buscarão, dentre dois portfólios, sempre o com maior retorno esperado e, sempre desejarão deter um nível de riqueza maior no fim do período investido que o que detinham no início do mesmo. Outra suposição é sobre aversão ao risco. Segundo o autor, em geral, é assumido que os investidores são avessos ao risco, o que os leva a buscar sempre um portfólio com menor desvio-padrão para realizarem seus investimentos. O risco considerável é o risco suficiente para afetar a decisão do investidor e, está fundamentalmente ligado à intensidade da aversão desse investidor ao risco. Um indivíduo pode rejeitar um possível investimento, mesmo podendo receber um 
prêmio de risco positivo, pelo fato de o ganho adicionado ao investimento não ser suficiente para compensar o risco envolvido.

Um investidor avesso a riscos tende a rejeitar investimentos em portfólios que tenham prêmio de risco igual a zero. Para Bodie et al., investidores avessos a riscos desejam considerar somente ativos livres de riscos ou especulações com prêmio de risco positivo, ou seja, esses investidores penalizam a taxa de retorno esperado de um ativo, ou portfólio, em certa proporção, pelo fato de o risco existir.

A questão envolvida na seleção do portfólio ótimo, dado um conjunto de possíveis portfólios que se possa selecionar, baseia-se no teorema da fronteira eficiente. Esse teorema afirma que, dentro de uma variedade de níveis de risco possíveis, o investidor irá escolher o portfólio ótimo que the ofereça o máximo retorno esperado; da mesma forma, dentro de uma variedade de níveis de retorno esperado possíveis, ele irá escolher um portfólio que lhe ofereça o mínimo risco. Para Sharpe et al. (1998, p.171) o conjunto de portfólios que encontram estas duas condições, é conhecido como ou fronteira eficiente. A região situada internamente ao limite da fronteira eficiente é chamada de conjunto viável. Essa região representa todos os portfólios que poderiam ser formados de um conjunto de $n$ ativos. A representação gráfica da fronteira eficiente, e da região viável, pode ser observada no gráfico 4 .

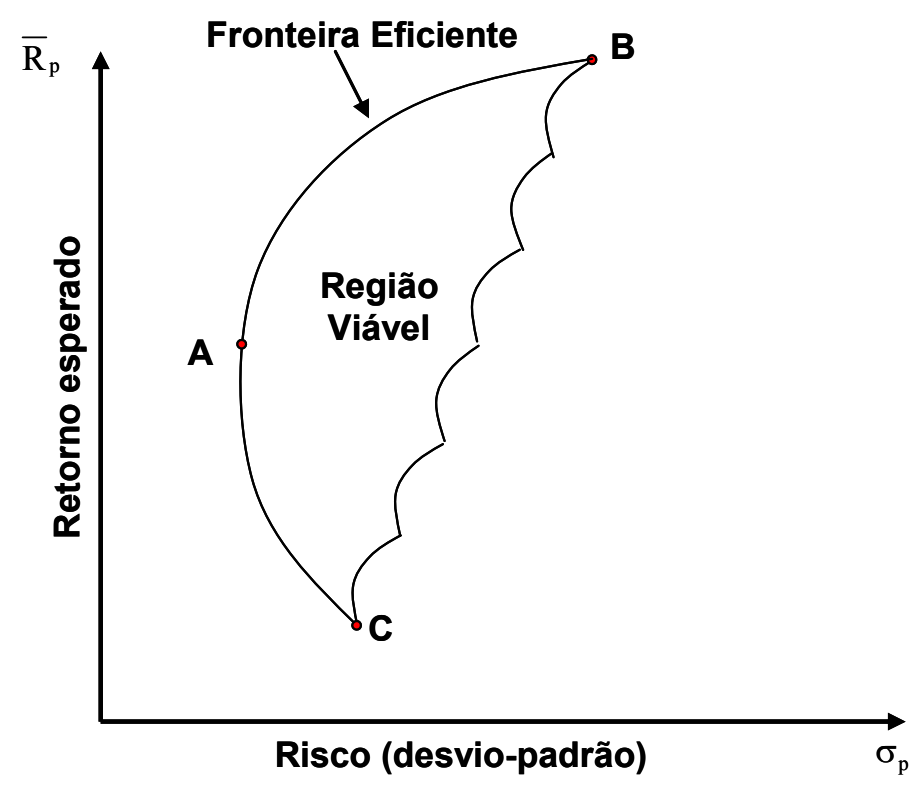

Gráfico 4 - Representação gráfica da fronteira eficiente e região viável 
Considerando as suposições implícitas no modelo de Markowitz, o ponto A, do gráfico 4, representa o portfólio de menor risco. Da mesma forma, os pontos B e C, são, respectivamente, os pontos de maiores e menores retornos esperados para um portfólio. Assim, um conjunto de portfólios oferecendo mínimo risco para diferentes níveis de retornos esperados situa-se na fronteira eficiente entre os pontos A e B.

Um portfólio, definido a partir de um conjunto de ativos, assume características de um único ativo. Luenberger (1988, p.151) afirma que, quando composto por poucos ativos, pode ficar sujeito a um alto grau de risco, representado pelo desvio-padrão, relativamente alto. Como regra geral, o desvio-padrão de um portfólio pode ser reduzido, incluindo mais ativos, processo chamado de diversificação. A questão que envolve a diminuição do risco de um portfólio, por inclusão de mais ativos, fundamenta-se no conceito estatístico de correlação. Se os retornos dos ativos são não correlacionados, ou apresentam correlação negativa, o desvio-padrão do portfólio formado por esses ativos, tende a decrescer, quando comparado ao desvio-padrão dos retornos de um dos ativos sozinhos; no entanto, se forem positivamente correlacionados, o desvio-padrão tende a crescer. Dessa forma a diversificação, geralmente, leva à redução de risco.

Supõe-se que dois ativos sejam combinados em proporções, tais que a soma seja igual a 100\%. O retorno esperado e o risco desse portfólio podem ser calculados a partir das médias, variâncias e covariâncias, das taxas de retornos dos ativos utilizados. Ao combinar dois ativos para formar um portfólio, com $\alpha$ proporção de um ativo e 1- 1 proporção do outro, nota-se que quanto mais negativa for a correlação entre as taxas de retornos dos ativos, mais côncava à esquerda torna-se a fronteira eficiente. Da mesma forma, quanto mais positiva é a correlação, menos côncava torna-se a fronteira eficiente.

A inclusão de um ativo livre de riscos na composição de um portfólio causa um efeito interessante na estrutura risco-retorno do portfólio, pelo fato desse ativo ter um retorno que é determinístico, ou seja, com risco nulo. Sharpe considera haver duas possibilidades de o indivíduo investir nesse ativo. Uma por alocação de parte 
de sua própria riqueza inicial e outra por alavancagem, tomando recurso emprestado no mercado.

Considerando que todos os indivíduos, racionalmente, buscam maximizar o retorno esperado do portfólio, todos os possíveis portfólios a serem estruturados combinando ativos com risco e ativo livre de risco, estarão, situados em uma linha representativa, a qual liga desde o ponto que representa o retorno do ativo livre de risco, até um ponto da fronteira eficiente que represente a composição de um portfólio apenas com ativos com risco, de acordo com o perfil de aversão ao risco desse indivíduo.

A teoria do portfólio fundamenta o propósito do presente trabalho, uma vez que as estratégias de hedge estudadas são estruturadas sobre um portfólio composto por dois ativos, um no mercado à vista e outro no mercado futuro. Outro fator importante, é que, ao utilizar uma estratégia de hedging, o individuo, neste caso o produtor agrícola, está interessado em obter um portfólio ótimo, dado uma gama de possíveis portfólios que podem ser obtidos, combinando diferentes proporções dos ativos utilizados.

Fundamentado nas funções utilizadas pelas diferentes estratégias estudadas, o produtor está, implicitamente, baseado nas suposições apresentadas pelo modelo de Markowitz, buscando determinar o portfólio com maior retorno esperado, no entanto, com menor risco.

\section{4. Índice de Sharpe}

O índice de Sharpe (IS) é uma avaliação de desempenho de um portfólio, cuja idéia essencial é comparar o retorno obtido, em determinado período, com o investimento em um outro denominado de benchmark.

De acordo com Sharpe et al. (1998, p.844) o índice, que foi referenciado ao seu nome, é uma medida de desempenho ajustada ao risco, que usa como benchmark o capital market line $(C M L)$ histórico. Dado que um portfólio pode ser sumarizado sobre duas medidas estatísticas, o retorno esperado e o desvio-padrão 
dos retornos sobre o portfólio, pode-se obter um portfólio eficiente com o máximo retorno esperado e o mínimo risco. O CML é, portanto, a linha que representa todos os possíveis portfólios que podem ser formados combinando este portfólio original, contendo apenas ativos com risco, com um ativo livre de riscos. Isto posto, o índice de Sharpe mede o retorno relativo ao risco total do portfólio, onde o risco total é o desvio-padrão dos retornos do portfólio. Dessa forma esse índice é definido como:

$$
I S=\frac{E\left(R_{p}\right)-r_{f}}{\sigma\left(R_{p}\right)}
$$

Em que:

$\mathrm{E}\left(\mathrm{R}_{\mathrm{p}}\right)$ : valor médio dos retornos do portfólio;

$\mathrm{r}_{\mathrm{f}}$ : taxa de retorno do ativo livre de risco;

$\sigma\left(\mathrm{R}_{\mathrm{p}}\right)$ : desvio-padrão dos retornos do portfólio.

Em outras palavras, o índice de Sharpe mede o prêmio exigido em retorno, por incorporar ao portfólio original, ativos com mais risco de crédito que o ativo livre de riscos, relativo ao aumento no nível de risco proporcionado por estes ativos ao portfólio.

\subsection{Conceito de Utilidade}

A utilidade constitui uma forma de descrever as preferências de consumo do indivíduo, em diferentes circunstâncias. Segundo Varian (2000, p.57), a função utilidade é um modo de atribuir um número a cada possível "cesta" de consumo ${ }^{6}$, de forma que se atribuam às "cestas" mais preferidas valores maiores. Ou seja, o principal propósito de uma função utilidade é fornecer um meio sistemático de ordenar alternativas que capturam o princípio de aversão ao risco de um indivíduo, o qual explica o comportamento de consumidores, e de investidores, na tomada de decisão sob incerteza, que é obtida sempre que uma função utilidade é côncava.

\footnotetext{
${ }^{6}$ Cesta é definido como um conjunto de bens ou produtos que podem ser adquiridos por um indivíduo.
} 
No entanto, ao analisar a escolha sob incerteza, deve-se levar em questão a probabilidade de ocorrência do consumo. Dessa forma, ao considerar a distribuição de probabilidades em se obter uma determinada cesta de consumo, a função utilidade caracteriza-se como função de utilidade esperada, ou função de utilidade Von Neumann-Morgestern ${ }^{7}$.

\subsubsection{Tipos de Função Utilidade}

A função utilidade de um indivíduo descreve sua atitude na decisão de consumo frente ao risco. Assim, uma função utilidade assume formas peculiares, de acordo com a tolerância ao risco pelo indivíduo e sua condição financeira, podendo este ser avesso ao risco, neutro ao risco ou propenso ao risco, sempre com o objetivo de maximizar a utilidade esperada.

Como forma de conceituar os diferentes tipos de função utilidade, considerase a utilidade atribuída pelo indivíduo, quanto ao seu comportamento, quando dada uma variação de sua riqueza (W) associada a seu perfil de risco.

\subsubsection{Indivíduo Avesso ao Risco}

A principal característica desse indivíduo é que ele é muito mais sensível a perdas de riqueza que a ganhos. Para ele, o ganho de utilidade pelo aumento de riqueza, é menor que pela perda de utilidade pela diminuição de riqueza.

A função utilidade que caracteriza tal indivíduo é côncava, ou seja, a derivada segunda dessa função é menor que zero, $\mathrm{U}^{\prime \prime}(\mathrm{W})<0$, implicando que à medida que aumenta a riqueza, a inclinação da função tende a diminuir.

A definição da função utilidade côncava que caracteriza o indivíduo com perfil avesso ao risco, é dada por:

\footnotetext{
${ }^{7}$ John Von Newmann, matemático e Oscar Morgenstern, economista, foram os autores que estabeleceram o conceito de função de utilidade esperada na literatura.
} 


$$
\mathrm{U}\left[\alpha\left[\mathrm{W}_{1}+(1-\alpha) \mathrm{W}_{2}\right]>\alpha \mathrm{U}\left(\mathrm{W}_{1}\right)+(1-\alpha) \mathrm{U}\left(\mathrm{W}_{2}\right)\right.
$$

Em que:

$\mathrm{W}_{1}$ e $\mathrm{W}_{2}$ : valores de riqueza;

$\alpha \in[0,1]$.

Uma característica desse indivíduo é que ele atribui maior utilidade ao valor esperado da riqueza, que à utilidade esperada dela.

\subsubsection{Indivíduo Neutro ao Risco}

O indivíduo neutro ao risco atribui a mesma utilidade tanto para o ganho de riqueza, quanto para perda. Esse se caracteriza por ser indiferente na ponderação de utilidade, dada a variação de riqueza.

A definição da função de utilidade que caracteriza tal indivíduo é uma função linear, dada por:

$$
\mathrm{U}(\mathrm{W})=\mathrm{W}
$$

\subsubsection{Indivíduo Propenso ao Risco}

O indivíduo propenso ao risco é mais sensível ao ganho de riqueza que a perda. Para ele, a atribuição de ganho em utilidade pelo aumento de riqueza, é maior que sua atribuição pela diminuição da mesma.

A função utilidade que caracteriza tal indivíduo é convexa, ou seja, a derivada segunda dessa função é maior que zero, $U^{\prime \prime}(W)>0$, implicando que à medida que aumenta a riqueza, a inclinação da função tende a aumentar.

A definição da função utilidade convexa que caracteriza o indivíduo com perfil propenso ao risco, é dada por: 


$$
\mathrm{U}\left[\alpha\left[\mathrm{W}_{1}+(1-\alpha) \mathrm{W}_{2}\right]<\alpha \mathrm{U}\left(\mathrm{W}_{1}\right)+(1-\alpha) \mathrm{U}\left(\mathrm{W}_{2}\right)\right.
$$

Em que:

$\mathrm{W}_{1}$ e $\mathrm{W}_{2}$ : valores de riqueza;

$\alpha \in[0,1]$.

Uma característica desse indivíduo, é que ele atribui menor utilidade ao valor esperado da riqueza.

\subsection{Derivativos}

Uma bolsa de mercadorias é um local onde os indivíduos podem negociar contratos, denominados derivativos, padronizados e normatizados pela mesma. De acordo com Hull (2003, p.1), "um derivativo pode ser definido como um instrumento financeiro cujo valor depende, ou deriva, do valor de outro, com variáveis subjacentes mais básicas. Muito freqüentemente, as variáveis subjacentes dos derivativos são os preços dos ativos negociados".

Como relatado por Chisholm (2004, p. 4) e Hull (op. cit.), a Chicago Board of Trade (CBOT) foi pioneira na negociação de derivativos. Fundada em 1848 por 82 comerciantes, o objetivo era permitir a padronização das quantidades e das qualidades dos grãos negociados. Em 1851, foi negociado o primeiro contrato a termo sobre grão de milho, o qual ganhou popularidade rapidamente.

Em 1865, devido à defaults sobre os contratos a termo negociados, a CBOT formalizou a negociação sobre grãos, desenvolvendo acordos padronizados, chamados de contratos futuros.

\subsubsection{Contratos Futuros}


Segundo Hull (2003, p.2) um contrato futuro é um acordo entre duas partes, para comprar ou vender um ativo específico, em determinada data no futuro, a um preço previamente estabelecido entre elas. Esses contratos são tradicionalmente negociados em ambiente de bolsa de mercadorias, a qual estabelece normas e especifica padronizações, com objetivo de tornar o negócio possível e garantir que o contrato acordado entre as partes seja honrado.

Os contratos futuros possuem especificações, que determinam a natureza exata do acordo feito entre as partes, tais como o ativo, o tamanho do contrato (quanto do ativo em cada contrato) e onde, e quando, será feito a entrega do ativo. No caso de commodities agrícolas, o local de entrega do produto físico é muito importante e deve ser determinado pela bolsa, uma vez que custos com fretes podem ser significativos.

O indivíduo com posição comprada em contrato futuro assume o compromisso de comprar determinado ativo, nas especificações descritas nesse contrato (quantidade, qualidade, local de entrega, etc.), em determinada data futura, ao preço negociado entre as partes, denominado preço de entrega. Da mesma forma é valido para o indivíduo com posição vendida, no entanto, esse assume o compromisso de vender o ativo.

Ao abrir posição comprada ou vendida em contrato futuro, o indivíduo está intrinsecamente assegurando a compra ou venda de determinado ativo, ao preço firmado entre as contrapartes, nas condições especificadas pelo contrato. Isto é, há uma fixação ou trava do preço de negociação deste ativo, para determinada data futura. No entanto, há risco de uma das partes, ou ambas, desistirem do negócio e não honrarem o compromisso. Como o papel da bolsa é permitir um ambiente organizado e seguro para negociações dos contratos de derivativos, um meio legal de mitigar tal risco, é a exigência de margem de garantia.

A liquidação de um contrato futuro é condicionada ao ativo subjacente negociado. No caso de commodities, caso o contrato seja levado até o vencimento, o seu comprador deverá comprar o ativo, nas condições especificadas. No entanto, este não é obrigado a manter sua posição até o vencimento, podendo, portanto, 
encerrá-la antecipadamente. Para isso deve obrigatoriamente abrir uma posição contrária a original, ou seja, vendida, no mesmo contrato, com as mesmas especificações para a mesma data de entrega. Nesse caso, a liquidação se dará apenas financeiramente pelo ajuste entre o preço acordado na negociação do contrato e o preço atual no mercado, podendo ser apurado lucro ou prejuízo ao comprador.

Para o indivíduo com posição vendida, caso o contrato seja levado até o vencimento, este deverá vender o ativo nas mesmas condições. Por conseguinte, caso queira encerrá-la antes do vencimento, da mesma forma que para a posição comprada, deve necessariamente, abrir uma posição contrária a sua atual, no mesmo contrato, com as mesmas especificações para a mesma data de entrega.

Para ativos financeiros não há entrega física do mesmo, neste caso, para ambas as posições, comprada ou vendida, o contrato sendo levado ao vencimento, ou encerrado antecipadamente, a liquidação ocorre apenas financeiramente pelo ajuste entre o preço acordado na negociação do contrato e o preço atual no mercado.

Outra característica dos contratos futuros é seu ajuste diário. O preço de ajuste do dia consiste na média dos preços pelo qual o contrato foi negociado imediatamente antes do término do pregão do dia. Com base nesse preço, são calculadas as perdas e os ganhos diários sobre as posições, além das variações no saldo da conta de margem.

A margem de garantia funciona como uma espécie de fundo garantidor contra inadimplências contratuais, uma vez que há riscos iminentes de ambas as partes desistirem do contrato, ou não honrarem seus compromissos. Segundo Hull (2003, p.6), um indivíduo ao abrir uma posição comprada em determinado ativo, para determinado vencimento, é obrigado a depositar, junto ao seu corretor, recursos proporcionais ao volume da operação e esse, por sua vez, a depositá-los na bolsa, mais precisamente numa conta chamada conta de margem. Ao final de cada dia de operação, haverá um ajuste, segundo o qual o investidor poderá ter de pagar, caso o preço de fechamento do dia seja menor que o preço em contrato; ou de receber, 
caso o preço de fechamento seja maior que o preço em contrato, proporcional ao número de contratos acordados. Quando o volume de recursos for maior que a margem inicial (depositada na abertura da posição), o investidor poderá sacar o excedente. Contudo, se o volume de recursos estiver abaixo da margem de manutenção, o investidor receberá uma chamada de margem, que o obriga a depositar recursos complementares até o limite da margem inicial, sempre proporcional ao número de contratos em aberto. Quando houver chamada de margem e o investidor não a forneça, a corretora tem o direito de zerar sua posição, vendendo seus contratos.

Para o autor os níveis de margem inicial e de margem de manutenção são determinados pelas bolsas, e iguais, tanto para os comprados quanto para os vendidos, além de influenciados pela variabilidade do preço do ativo em questão e pelo perfil do negociador. Se o preço do ativo é mais volátil, as margens serão maiores e vice-versa. Se o negociador for um hedger, suas margens serão menores que as de um especulador, pois seus riscos de inadimplência serão menores, caso seja o produtor da commodity que referencia o contrato futuro.

De acordo com Chisholm (2004, p.2) e Hull (2003, p.10), dentre os participantes dos mercados futuros, três figuras têm papéis fundamentais: os hedgers, os especuladores e os arbitradores.

Os hedgers são indivíduos para os quais os mercados futuros foram originalmente criados, com o intuito de atender às suas necessidades. Os produtores e os comerciantes são as principais figuras a assumir tal papel. Os primeiros por precisar de uma estrutura que lhes permitisse garantir o preço de venda de sua produção para uma data futura e os segundos por precisar de uma estrutura que lhes garantisse o preço de compra de determinados produtos. Ambos por não poderem ficar expostos ao risco de oscilação de preço.

Os especuladores são figuras que assumem o risco de oscilação de preço, dos quais os hedgers querem se afastar, assumindo às vezes posição contrária à dos hedgers. Os especuladores e os hedgers são figuras de extrema importância para a liquidez do mercado. 
Já os arbitradores têm o objetivo de obter lucro, realizando operações simultâneas em dois mercados, sem envolver qualquer tipo de risco. No entanto são operações que ocorrem em um pequeno espaço de tempo no mercado, uma vez que ao perceber disparidades, esse se ajusta por oferta e demanda.

\subsection{A Teoria do Hedging}

Diversos autores que desenvolveram estudos sobre estratégias de hedging, apresentam alguma definição para o conceito. Em sua maioria, definem hedging como uma trava, ou como um tipo de seguro, que permite mitigar a exposição a um determinado fator de risco.

Existem dois tipos de hedging com contratos futuros: o de venda e o de compra. O hedging de venda requer uma posição vendida em contratos futuros e é apropriada quando empresas ou indivíduos possuem um ativo e esperam vendê-lo no futuro. O hedging de compra, por sua vez, requer uma posição comprada em contratos futuros e é apropriado quando empresas ou indivíduos precisam adquirir determinado ativo no futuro. Em ambos os tipos há interesse das partes em travar o preço antecipadamente.

Sobre o ponto de vista de portfólio, considera-se o mesmo hedgeado, quando uma vez posicionado em determinada quantidade de um ativo, abre-se posição em contrato (s) futuro(s), proporcional à quantidade do ativo que se queira hedgear, com objetivo de travar seu preço de comercialização em data futura. Dessa forma, um portfólio hedgeado, é aquele composto por dois ativos, um no mercado à vista, e outro no mercado futuro.

Ederington (1979, p. 159) apresentou em seu trabalho três diferentes teorias sobre o conceito: a Teoria Tradicional, a Teoria de Holbrook Working e a Teoria do Portfólio. Segundo o autor, a Teoria Tradicional enfatiza evitar o risco potencial dos mercados futuros. Uma premissa dessa teoria é que os hedgers são determinados a posicionar-se em contratos futuros, iguais em magnitude, mas com posição contrária à do mercado à vista, para evitar o risco de preço sobre o ativo mantido nesse 
mercado. Assim, dada uma posição de $\mathrm{x}_{\mathrm{s}}$ unidades de certo ativo no mercado à vista, o indivíduo se protegeria contra a queda no seu preço, vendendo contrato futuro correspondente à quantidade $\mathrm{x}_{\mathrm{f}}$ do mesmo ativo. Tal procedimento foi denominado como hedging inocente (naïve) por muitos autores.

Sendo $\mathrm{P}_{\mathrm{s}}^{1}$ e $\mathrm{P}_{\mathrm{s}}^{2}$, os preços do ativo no mercado à vista, e $\mathrm{P}_{\mathrm{f}}^{1}$ e $\mathrm{P}_{\mathrm{f}}^{2}$ sejam os preços desse ativo no mercado futuro, em $t_{1}$ e $t_{2}$ respectivamente; sob o ponto de vista dessa teoria, o ganho ou perda sobre um portfólio não-hedgeado e um portfólio hedgeado, são definidos respectivamente como:

$$
\begin{gathered}
\mathrm{NH}_{\mathrm{p}}=\mathrm{x}_{\mathrm{s}}\left[\mathrm{P}_{\mathrm{s}}^{2}-\mathrm{P}_{\mathrm{s}}^{1}\right] \\
\mathrm{H}_{\mathrm{p}}=\mathrm{x}_{\mathrm{s}}\left\{\left[\mathrm{P}_{\mathrm{s}}^{2}-\mathrm{P}_{\mathrm{s}}^{1}\right]-\left[\mathrm{P}_{\mathrm{f}}^{2}-\mathrm{P}_{\mathrm{f}}^{1}\right]\right\}
\end{gathered}
$$

Em que:

$\mathrm{NH}_{\mathrm{p}}$ : ganho ou perda do portfólio não-hedgeado;

$\mathrm{H}_{\mathrm{p}}$ : ganho ou perda do portfólio hedgeado;

$\mathrm{x}_{\mathrm{s}}$ : quantidade do ativo no mercado à vista.

Essa teoria afirma que, geralmente, o preço à vista e o preço futuro movemse juntos, ou seja, a covariância entre eles é positiva. Por tal fato, o valor absoluto de $\mathrm{H}_{\mathrm{p}}$ é menor que o valor absoluto de $\mathrm{NH}_{\mathrm{p}}$, ou a variância de $\mathrm{H}_{\mathrm{p}}$ é menor que a variância de $\mathrm{NH}_{\mathrm{p}}$.

Dessa forma, essa questão é freqüentemente discutida em termos de variação sobre o preço à vista versus a variação sobre a diferença entre o preço futuro e o preço à vista em determinado período. Essa diferença, denominada base, é definida como $\left\{\left(\mathrm{P}_{\mathrm{f}}^{2}-\mathrm{P}_{\mathrm{s}}^{2}\right)-\left(\mathrm{P}_{\mathrm{f}}^{1}-\mathrm{P}_{\mathrm{s}}^{1}\right)\right\}$ e um hedging é visto como perfeito, se a variação da base é zero. 
Working (1953) criticou a consideração de que os preços no mercado à vista e os preços no mercado futuro, variam no mesmo montante, afirmando ser esta a maior fonte de erro na consideração sobre estratégia de hedging. O autor questionou a teoria fundamentada na visão de que os hedgers são puros minimizadores de risco, enfatizando o aspecto da maximização do lucro esperado, considerando os hedgers muito mais como especuladores.

Em sua visão, uma vez que os hedgers mantinham posição no mercado à vista, estavam envolvidos com o movimento relativos dos preços deste mercado e do mercado futuro e não no movimento absoluto. Dessa forma, ao invés de esperar que os preços no mercado à vista e futuro se movimentassem juntos, defendeu que a maioria das estratégias de hedging fosse estruturada sob a expectativa de variação relativa entre os preços nos dois mercados.

Outra teoria apresentada por Ederington é a fundamentada na Teoria do Portfólio. Segundo o autor, por verem a estratégia de hedging como uma aplicação da teoria do portfólio, Johnson (1960) e Stein (1961), foram capazes de integrar a busca pela mínima exposição ao risco, baseada nos princípios da teoria tradicional, com a busca pela maximização do lucro esperado, baseada nos princípios da teoria de Holbrook Working. No entanto, Ederington (1979, p.161) afirma que não há premissa, como na Teoria Tradicional, de que se deva estar com posição vendida em contratos futuros para se hedgear uma posição comprada no mercado à vista. Pode ocorrer de terem a mesma posição nos dois mercados, para atingir tal objetivo.

\subsubsection{Conceito de Estratégia de Hedging com Mercado Futuro}

Uma estratégia de hedging utilizando contratos no mercado futuro consiste em, ao estar posicionado em determinada quantidade de um ativo no mercado à vista, decide-se tomar posição em determinado número de contratos no mercado futuro, compondo dessa forma um portfólio, cujo objetivo é mitigar, ao máximo, o risco financeiro do ativo mantido no mercado à vista. A hipótese por trás da estratégia é que, a exposição ao risco financeiro de estar posicionado no ativo no mercado à vista, seja reduzido pelo fato posicionar-se em outro ativo, em outro mercado, ou seja pelo portfólio. 
Partindo do ponto de vista do produtor agrícola, que é o propósito desse trabalho, considera-se que esse tem posição comprada no ativo e precisará vendê-lo no futuro. Uma vez mantida tal posição, o produtor tem uma posição não-hedgeada, ou descoberta, ficando exposto às oscilações de preço do ativo no mercado à vista.

Ao estruturar um portfólio assumindo posição em contrato no mercado futuro com o objetivo de fazer o hedging, o produtor agrícola transfere a exposição ao risco do ativo no mercado à vista, para a exposição do risco do portfólio. A quantidade ótima a ser posicionada, comprado ou vendido, em contrato futuro (razão ótima de hedging), com objetivo de mitigar ao máximo à exposição ao risco de preço do ativo no mercado à vista, será determinada pela estratégia utilizada.

A razão ótima de hedging pode ser derivada de modelos teóricos ou de modelos empíricos. A derivação de modelos teóricos é determinada pela minimização de uma função-objetivo sobre a qual a estratégia é estruturada. A razão ótima de hedging também pode derivada de modelos empíricos. Uma forma tradicionalmente usada para tal propósito é a análise de regressão linear, simples ou múltipla, sobre as quais a razão ótima de hedging é determinada pelo coeficiente angular da função que representa o modelo. O coeficiente, ou parâmetro, associado a cada variável, representa a taxa de variação da variável dependente, com relação à variação de uma unidade da variável independente a qual está associada. Em linhas gerais, o coeficiente angular mede a taxa de variação da função com relação a uma determinada variável. Essa mesma medida é, de forma similar, obtido pela derivada primeira dessa função em relação a essa mesma variável. Por tal similaridade é que a razão ótima de hedging pode ser determinada sobre as duas formas de análise.

\subsubsection{Retorno e Lucro do Portfólio Hedgeado}

O retorno de um portfólio hedgeado, no qual implicitamente assume-se que para hedgear uma posição comprada no mercado à vista, abre-se uma posição vendida em contratos no mercado futuro, é definido sobre os retornos dos preços dos ativos que o compõem, conforme apresentado por Chen et al. (2003, p.435): 


$$
R_{h}=\frac{x_{s} P_{s} R_{s}-x_{f} P_{f} R_{f}}{x_{s} P_{s}}=R_{s}-b R_{f}
$$

Por outro lado, o lucro, ou a variação de valor de um portfólio hedgeado é definido sobre a variação dos preços dos ativos que o compõem:

$$
\Delta_{\mathrm{h}}=\mathrm{x}_{\mathrm{s}} \Delta \mathrm{P}_{\mathrm{S}}-\mathrm{x}_{\mathrm{f}} \Delta \mathrm{P}_{\mathrm{f}}
$$

Em que:

$\mathrm{x}_{\mathrm{S}}$ : unidades da posição no mercado à vista;

$\mathrm{x}_{\mathrm{f}}$ : unidades da posição no mercado futuro;

$\mathrm{P}_{\mathrm{S}}$ : preço à vista;

$\mathrm{P}_{\mathrm{f}}$ : preço futuro;

$\mathrm{R}_{\mathrm{S}}$ : retorno do preço à vista;

$\mathrm{R}_{\mathrm{f}}$ : retorno do preço futuro;

$\Delta \mathrm{P}_{\mathrm{S}}=\left(\mathrm{P}_{\mathrm{st}}-\mathrm{P}_{\mathrm{St}-1}\right)$ : variação do preço à vista;

$\Delta \mathrm{P}_{\mathrm{f}}=\left(\mathrm{P}_{\mathrm{ft}}-\mathrm{P}_{\mathrm{ft}-1}\right)$ : variação do preço futuro;

b : razão ótima de hedging;

$\mathrm{R}_{\mathrm{h}}$ : retorno do portfólio hedgeado;

$\Delta_{\mathrm{h}}$ : variação do valor, ou lucro, do portfólio hedgeado.

A razão de hedging, $b$, refere-se ao número ótimo de contratos a se posicionar no mercado futuro, relativo à quantidade do ativo no mercado à vista que se queira hedgear.

\subsubsection{Variância dos Retornos e dos Lucros do Portfólio Hedgeado}

Uma vez definido o retorno e o lucro de um portfólio hedgeado, a definição das variâncias sobre eles é imediata: 


$$
\begin{gathered}
\sigma^{2}\left(\mathrm{R}_{\mathrm{h}}\right)=\sigma^{2}\left(\mathrm{R}_{\mathrm{s}}\right)+\mathrm{b}^{2} \sigma^{2}\left(\mathrm{R}_{\mathrm{f}}\right)-2 \mathrm{~b} \sigma\left(\mathrm{R}_{\mathrm{s}}, \mathrm{R}_{\mathrm{f}}\right) \\
\sigma^{2}\left(\Delta_{\mathrm{h}}\right)=\mathrm{x}_{\mathrm{s}}^{2} \sigma^{2}\left(\Delta \mathrm{P}_{\mathrm{s}}\right)+\mathrm{x}_{\mathrm{f}}^{2} \sigma^{2}\left(\Delta \mathrm{P}_{\mathrm{f}}\right)-2 \mathrm{x}_{\mathrm{s}} \mathrm{x}_{\mathrm{f}} \sigma\left(\Delta \mathrm{P}_{\mathrm{s}}, \Delta \mathrm{P}_{\mathrm{f}}\right)
\end{gathered}
$$

Em que:

$\sigma^{2}\left(\mathrm{R}_{\mathrm{h}}\right)$ : variância dos retornos do portfólio hedgeado;

$\sigma^{2}\left(R_{S}\right)$ : variância dos retornos do preço à vista;

$\sigma^{2}\left(R_{f}\right)$ : variância dos retornos do preço futuro;

$\sigma\left(R_{S}, R_{f}\right)$ : variância entre o retorno dos preços à vista e preço futuro;

$\sigma^{2}\left(\Delta_{h}\right)$ : variância da variação do valor, ou lucro, do portfólio hedgeado;

$\sigma^{2}\left(\Delta \mathrm{P}_{\mathrm{S}}\right)$ : variância da variação do preço à vista;

$\sigma^{2}\left(\Delta \mathrm{P}_{\mathrm{f}}\right)$ : variância da variação do preço futuro;

$\sigma\left(\Delta \mathrm{P}_{\mathrm{S}}, \Delta \mathrm{P}_{\mathrm{f}}\right)$ : covariância entre a variação dos preços à vista e preço futuro.

\subsubsection{Eficácia da Estratégia de Hedging}

A mensuração da eficácia da uma estratégia de hedging depende do objetivo sobre a qual ela é estruturada. A quantificação da eficácia de uma estratégia é realizada efetuando a comparação de uma determinada medida sobre o portfólio, denominado portfólio hedgeado, relativo a essa mesma medida sobre a posição no mercado à vista, denominado não-hedgeada.

Estratégias que consideram apenas a análise do risco na obtenção da razão ótima de hedging mensuram sua eficácia, comparando o risco da posição mantida no mercado à vista relativo ao risco do portfólio hedgeado. Dessa forma, quanto menor for o risco sobre o portfólio hedgeado frente o risco da posição mantida no mercado à vista, mais eficaz é a estratégia. Como mostrado por Johnson (1960), 
Chen et al. (2003), Demirer et al. (2005), entre outros; analiticamente essa medida é definida, como:

$$
\mathrm{e}=1-\frac{\mathrm{M}_{\mathrm{h}}}{\mathrm{M}_{\mathrm{S}}}
$$

Em que:

$\mathrm{M}_{\mathrm{h}}$ : medida de risco do portfólio hedgeado;

$\mathrm{M}_{\mathrm{S}}$ : medida de risco da posição no mercado à vista.

Para essa medida, quanto mais e se aproximar de 1, mais eficaz é a estratégia. 


\section{ESTRATÉGIAS DE HEDGING}

Neste capítulo apresentam-se as estratégias de hedging estáticas analisadas no presente trabalho. Cada estratégia é baseada em uma premissa, sobre a qual se propõe obter a quantidade ótima a se posicionar em contratos no mercado futuro, com o intuito de hedgear uma posição em determinada quantidade de um ativo no mercado à vista. Essa razão, também é denominada de razão ótima de hedging.

Há basicamente duas categorias de estratégias de hedging, a estática e a dinâmica. A estratégia estática caracteriza-se em uma vez definida a razão ótima de hedging, a posição em contratos no mercado futuro é mantida até o final do período em que se queira manter a posição no mercado à vista hedgeada, também denominado de período da estratégia de hedging. Por outro lado, a estratégia dinâmica caracteriza-se por uma vez definida a razão ótima de hedging, essa é monitorada constantemente tendo a posição em contrato no mercado futuro rebalanceada. Essa categoria permite maior adequação às mudanças que ocorrem ao longo do período em que a estratégia se mantém.

No entanto, o constante rebalanceamento de uma estratégia dinâmica é operacionalmente cara ao hedger, pelo fato de ter que operar o contrato muitas vezes. Dessa forma, mesmo esse trabalho não considerando os custos operacionais na mensuração dos resultados, optou-se por realizá-lo considerando apenas as estratégias estáticas pelo fato de permitirem a redução desses custos, quando aplicadas à realidade. Outra consideração foi a opção por rebalancear as estratégias estáticas semanalmente, dando a elas um caráter dinâmico permitindo maior sensibilidade às mudanças no mercado.

Esse capítulo apresenta uma evolução histórica das estratégias estáticas apresentadas pela literatura e mais frequentemente utilizadas na prática pela facilidade de mensuração, abrangendo das mais antigas as mais recentes. Tal consideração permite identificar as incorporações que essas estratégias foram 
apresentando sobre as quais consideravam premissas fundamentais na determinação da razão ótima de hedging.

\subsection{Estratégia por Mínima Variância}

A estratégia de hedging por mínima variância foi originalmente apresentada por Johnson em 1960. Tal estratégia busca obter a razão de hedging através de um modelo, que tem como premissa obter a quantidade ótima a se posicionar em contratos no mercado futuro que minimizem o risco do portfólio, determinado pela medida de variância sobre a variação no valor, ou lucro, do portfólio hedgeado determinado pela equação (3.20).

Dado $\mathrm{x}_{\mathrm{f}}$, o número de contratos no mercado futuro e que a variância dos lucros sobre um portfólio hedgeado é uma função diferenciável e convexa dessa variável, a determinação do ponto de mínimo dessa função com relação a essa variável é dado pelo valor $\mathrm{x}_{\mathrm{f}}^{*}$, onde a derivada primeira desta função é igual à zero:

$$
\frac{\partial \sigma^{2}\left(\Delta_{h}\right)}{\partial x_{f}}=0
$$

Da equação (4.1) obtem-se, portanto, a razão ótima de hedging b, dada por:

$$
\mathrm{b}=\frac{\sigma\left(\Delta \mathrm{P}_{\mathrm{s}}, \Delta \mathrm{P}_{\mathrm{f}}\right)}{\sigma^{2}\left(\Delta \mathrm{P}_{\mathrm{f}}\right)}
$$

Em que:

$\Delta \mathrm{P}_{\mathrm{S}}:$ variação do preço à vista;

$\Delta \mathrm{P}_{\mathrm{f}}$ : variação do preço futuro;

$\sigma\left(\Delta \mathrm{P}_{\mathrm{S}}, \Delta \mathrm{P}_{\mathrm{f}}\right)$ : covariância entre a variação dos preços à vista e preço futuro; 
$\sigma^{2}\left(\Delta \mathrm{P}_{\mathrm{f}}\right)$ : variância da variação do preço futuro;

$\mathrm{b}$ : razão ótima de hedging.

A eficácia dessa estratégia foi determinada através da equação (3.21), para a qual foi considerado como medida de risco do portfólio hedgeado, a variância da variação do seu valor, ou lucro, dado pela equação (3.20) e como medida de risco da posição no mercado à vista, a variância da variação do preço à vista.

\subsection{Estratégia por Análise de Regressão Linear}

A estratégia apresentada por Ederington (1979) e Junkus e Lee (1985) é semelhante à apresentada por Johnson (1960) no que se refere à determinação da razão ótima de hedging por minimização do risco do portfólio, dado pela medida de variância sobre a variação no valor, ou lucro, do portfólio hedgeado, como apresentado pela equação (3.20). No entanto, Ederington e Junkus e Lee, diferenciam-se de Johnson à medida que se propuseram determinar a razão ótima de hedging baseado em um modelo de regressão linear.

Segundo o autor, a determinação da razão ótima de hedging utilizando um modelo de regressão linear é obtida através do coeficiente angular da equação de regressão, a qual utiliza como variável dependente, a variação do preço à vista $e$ como variável independente, a variação do preço futuro, o qual é estimado pelo método dos mínimos quadrados ordinários (MQO). A equação de regressão é dada por:

$$
\Delta \mathrm{P}_{\mathrm{s}}=\alpha+\mathrm{b} \Delta \mathrm{P}_{\mathrm{f}}+\varepsilon
$$

Em que:

$\Delta \mathrm{P}_{\mathrm{S}}=\left(\mathrm{P}_{\mathrm{st}}-\mathrm{P}_{\mathrm{st}-1}\right)$ : variação do preço à vista;

$\Delta \mathrm{P}_{\mathrm{f}}=\left(\mathrm{P}_{\mathrm{ft}}-\mathrm{P}_{\mathrm{ft}-1}\right)$ : variação do preço futuro;

$\varepsilon$ : erro aleatório; 
$\mathrm{b}$ : razão ótima de hedging.

Assume-se, como premissa do modelo clássico de regressão linear, que o erro aleatório, $\varepsilon$, tem distribuição aproximadamente à normal $\mathrm{N}\left(0 ; \sigma^{2}\right)$.

A eficácia dessa estratégia foi determinada através da equação (3.21), para a qual foi considerado como medida de risco do portfólio hedgeado, a variância da variação do seu valor, ou lucro, dado pela equação (3.20) e como medida de risco da posição no mercado à vista, a variância da variação do preço à vista.

\subsection{Estratégia por Maximização do Índice de Sharpe}

Estratégias de hedging considerando a estrutura risco-retorno sobre o portfólio, surgiram com o intuito de preencher a lacuna deixada pela inconsistência das estratégias por mínima variância em não considerar o retorno esperado do portfólio na determinação da razão ótima de hedging, como mostrado nos trabalhos de Howard e D’Antonio (1984), Cecchetti et al. (1988) e Hsin et al. (1994). A proposta do trabalho destes autores foi baseada na maximização do índice de Sharpe como meio para determinar tal razão.

Howard e D'Antonio (1984, p.102), propunham derivar a razão ótima de hedging, baseado em um estudo sobre a alocação de recursos por um indivíduo. Segundo os autores, um indivíduo que deseja fazer um investimento tem a possibilidade de alocar seus recursos em três ativos: ou em um ativo no mercado à vista, ou em um ativo no mercado futuro ou em um ativo livre de risco.

No contexto do modelo proposto, um indivíduo pode reduzir o risco do portfólio mantendo, proporcionalmente, mais ativos livres de riscos. No entanto, a decisão de manter contratos futuros não é baseada apenas na redução de risco do portfólio, mas também na habilidade de eles otimizarem a estrutura risco-retorno do portfólio. A otimização dessa estrutura, conforme apresentado por Howard e D’Antonio (1984), Chang e Shanker (1987), Kuo e Chen (1995) e Satyanarayan 
(1998), é obtida pela maximização do índice de Sharpe com relação à razão de hedging, b.

Dessa forma, substituindo as equações (3.17) e (3.19) em (3.11), tem-se:

$$
I S=\frac{\left[E\left(R_{p}\right)-r f\right]-b E\left(R_{a}\right)}{\left(\sigma^{2}\left(R_{S}\right)+b^{2} \sigma^{2}\left(R_{a}\right)-2 b \sigma\left(R_{S}, R_{a}\right)\right)^{1 / 2}}
$$

Em que:

$\mathrm{E}\left(\mathrm{R}_{\mathrm{p}}\right)$ : valor médio dos retornos do portfólio;

$E\left(R_{a}\right)$ : valor médio dos retornos de $R_{a}$;

$\sigma^{2}\left(\mathrm{R}_{\mathrm{S}}\right)$ : variância dos retornos do preço à vista;

$\sigma^{2}\left(R_{a}\right)$ : variância dos retornos de $R_{a}$;

$\sigma\left(\mathrm{R}_{\mathrm{S}}, \mathrm{R}_{\mathrm{a}}\right)$ : covariância entre os retornos do preço à vista e $\mathrm{R}_{\mathrm{a}}$;

$\mathrm{R}_{\mathrm{a}}:\left(\frac{\mathrm{P}_{\mathrm{f}}^{0}}{\mathrm{P}_{\mathrm{S}}^{0}}\right)\left(\frac{\mathrm{P}_{\mathrm{f}}^{1}-\mathrm{P}_{\mathrm{f}}^{0}}{\mathrm{P}_{\mathrm{f}}^{0}}\right)$;

$\mathrm{P}_{\mathrm{f}}^{0}$ : preço futuro em $\mathrm{t}_{0}$;

$\mathrm{P}_{\mathrm{S}}^{0}:$ preço à vista em $\mathrm{t}_{0}$;

$\mathrm{R}_{\mathrm{f}}$ : retorno do preço futuro;

rf : retorno do ativo livre de risco;

b : razão ótima de hedging.

A determinação da razão ótima de hedging é obtida pela derivada primeira da equação (4.4) com relação à b, dada por:

$$
b=\frac{\sigma\left(R_{S}, R_{a}\right)\left[r f-E\left(R_{S}\right)\right]+E\left(R_{a}\right) \sigma^{2}\left(R_{S}\right)}{\sigma^{2}\left(R_{a}\right)\left[r f-E\left(R_{S}\right)\right]+E\left(R_{a}\right) \sigma\left(R_{S}, R_{a}\right)}
$$


A eficácia dessa estratégia foi determinada através da equação (3.21), para a qual foi considerado como medida de risco do portfólio hedgeado, a variância dos retornos desse, dado pela equação (3.19) e como medida de risco da posição no mercado à vista, a variância dos retornos do preço à vista.

Apesar de essa estratégia ser coerente com a estrutura média-variância, Chen et al. (2003, p. 438), apontam que pela relação de Sharpe ser uma função não-linear, não é possível afirmar que apenas a derivada de primeira ordem garanta que b seja um ponto de máximo da função. Para tal comprovação, é necessário analisar sua segunda derivada.

\subsection{Estratégia por Maximização da Utilidade Esperada}

Além dos trabalhos que apresentavam a proposta de definir uma estratégia de hedging consistente com a estrutura média-variância do portfólio, outros buscaram também ser consistentes a utilidade de um indivíduo, buscando determinar a razão ótima de hedging maximizando a utilidade esperada desse indivíduo, conforme apresentado nos trabalhos de Cecchetti (1988) e Hsin et al. (1994).

Analisando a atribuição de utilidade para um indivíduo avesso ao risco, determinado pelo ganho em retorno sobre um portfólio em condição de incerteza, pode-se definir a função de utilidade esperada desse indivíduo como:

$$
\mathrm{U}\left[\mathrm{E}\left(\mathrm{R}_{\mathrm{h}}\right), \sigma_{\mathrm{h}} ; \eta\left(\mathrm{R}_{\mathrm{h}}\right)\right]
$$

Em que:

$\mathrm{U}($.$) : função utilidade do investidor;$

$\mathrm{E}\left(\mathrm{R}_{\mathrm{h}}\right)$ : valor médio dos retornos do portfólio hedgeado;

$\sigma_{h}$ : desvio-padrão dos retornos do portfólio hedgeado. 
Em que $\eta\left(\mathrm{R}_{\mathrm{h}}\right)$ é o coeficiente absoluto de aversão ao risco, formalmente apresentado por Pratt (1964), determinado por:

$$
\eta\left(\mathrm{R}_{\mathrm{h}}\right)=\frac{-\mathrm{U}^{\prime \prime}\left(\mathrm{R}_{\mathrm{h}}\right)}{\mathrm{U}^{\prime}\left(\mathrm{R}_{\mathrm{h}}\right)}
$$

Em que:

$\mathrm{R}_{\mathrm{h}}=\mathrm{R}_{\mathrm{S}}-\mathrm{bR}$ : retorno do portfólio hedgeado.

Hsin et al. (op. cit., p. 689) assumem que o indivíduo que busca uma estratégia de hedging, é avesso ao risco. Assim, a função de utilidade esperada que o represente é côncava, condicionada a uma constante absoluta de aversão a riscos (absolute risk aversion - ARA).

Isto posto, considerando que o retorno sobre um portfólio hedgeado é determinado pela função (3.17), sua variância pela função (3.19) e os custos de transação iguais à zero, os autores determinam a razão ótima em contratos no mercado futuro para hedgear uma posição de um ativo no mercado à vista, é dado pela maximização da função utilidade esperada do indivíduo, com relação à razão de hedging, $b$, dado por:

$$
\underset{b}{\operatorname{Max}} U\left(E\left(R_{h}\right), \sigma_{h} ; \eta\left(R_{h}\right)=\underset{b}{\operatorname{Max}} E\left(R_{h}\right)-0.5 \cdot \eta\left(R_{h}\right) \cdot \sigma_{h}^{2}\right.
$$

Considerando que o valor extremo da função utilidade esperada é dado onde a derivada primeira dessa função é nula, tem-se:

$$
\frac{\partial \mathrm{U}\left[\mathrm{E}\left(\mathrm{R}_{\mathrm{h}}\right), \sigma_{\mathrm{h}} ; \eta\left(\mathrm{R}_{\mathrm{h}}\right)\right]}{\partial \mathrm{b}}=0
$$

Da equação (4.9), obtem-se a razão ótima de hedging, b: 


$$
b=\frac{\sigma\left(R_{S}, R_{f}\right)}{\sigma^{2}\left(R_{f}\right)}-\frac{E\left(R_{f}\right)}{\sigma^{2}\left(R_{f}\right) \eta\left(R_{h}\right)}
$$

Em que:

$\sigma\left(\mathrm{R}_{\mathrm{S}}, \mathrm{R}_{\mathrm{f}}\right)$ : covariância entre os retornos dos preços à vista e futuro;

$\sigma^{2}\left(R_{f}\right)$ : variância dos retornos do preço futuro;

$E\left(R_{f}\right)$ : valor médio dos retornos do preço futuro;

$\eta\left(R_{h}\right)$ : coeficiente absoluto de aversão ao risco.

A eficácia dessa estratégia foi determinada através da equação (3.21), para a qual foi considerado como medida de risco do portfólio hedgeado, a variância dos retornos desse, dado pela equação (3.19) e como medida de risco da posição no mercado à vista, a variância dos retornos do preço à vista.

Apesar de essa estratégia incorporar a estrutura risco-retorno do portfólio na determinação da razão ótima de hedging, afirmava-se que para ela ser consistente, era necessário que ou a função utilidade esperada do indivíduo fosse quadrática ou os retornos do portfólio hedgeado fossem normalmente distribuídos, uma vez que ela assume isso implicitamente.

Isto posto, alguns autores buscaram derivar a razão ótima de hedging baseados em uma estrutura que não dependesse de tais premissas. Uma alternativa foi utilizar como medida de risco do portfólio o coeficiente de Gini estendido, ao invés da variância dos retornos do portfólio hedgeado, por ser consistente com as regras de dominância estocástica.

\subsection{Estratégia por Minimização do Coeficiente de Gini Estendido}

A partir do trabalho de Shalit e Yitzhaki em 1984, muitos pesquisadores se empenharam em utilizar a medida alternativa de risco apresentada por eles na obtenção de uma estrutura ótima de risco-retorno para um portfólio. Por 
conseguinte, autores que questionavam a determinação da razão ótima de hedging sobre a estrutura média-variância do portfólio, pelo fato dela ser válida somente sobre a premissa de que ou os retornos dos preços dos ativos seguirem uma distribuição normal, ou a função de utilidade que representa o comportamento do indivíduo ser quadrática, passaram a utilizar o coeficiente de Gini como medida de risco por julgarem ela superior, pelo fato de ser consistente com as definições de dominância estocástica e não depender de tais premissas, como afirmado por Yitzhaki (2003). A pretensão desses autores era de empregá-lo como instrumento para estruturar uma estratégia de hedging que fosse eficiente utilizando derivativos como contratos futuros e opções.

Cheung et al. (1990), Kolb e Okunev (1992), Lien e Luo (1993), Shalit (1995) e Lien e Shaffer (1999), propuseram determinar a razão ótima de hedging sobre a premissa de minimização do coeficiente Gini estendido como medida de risco do portfólio, conforme definido pela equação (3.10). Kolb e Okunev (1993), também propuseram determinar a razão ótima de hedging utilizando o coeficiente de Gini estendido, no entanto, baseados na premissa de maximização da utilidade esperada do indivíduo, dada por $\mathrm{U}\left(\mathrm{R}_{\mathrm{h}}\right)=\mathrm{E}\left(\mathrm{R}_{\mathrm{h}}\right)-\Gamma$, otimizando a relação $\mathrm{E}\left(\mathrm{R}_{\mathrm{h}}\right)-\Gamma$, maximizando o retorno do portfólio hedgeado, $\mathrm{E}\left(\mathrm{R}_{\mathrm{h}}\right)$, e minimizando seu risco, $\Gamma$.

No entanto, para a minimização do coeficiente de Gini estendido, era necessário estimar a função de distribuição acumulada dos retornos do portfólio, $\mathrm{F}\left(\mathrm{R}_{\mathrm{p}}\right)$. Um método empírico de estimação utilizado por muitos autores, dentre eles Kolb e Okunev (1992), foi o ordenamento em ordem crescente da divisão dos retornos do portfólio pelo tamanho total da amostra do conjunto de dados considerados no período de análise, dado por $\hat{F}\left(R_{h, i}\right)=\frac{\left(R_{h, i}\right)}{N}$, e que Cheung et al. (2007), apresentaram de forma didática como obter. A razão ótima de hedging é então obtida pela razão entre a quantidade em contratos futuros e a quantidade do ativo no mercado à vista, que determina o mínimo coeficiente de Gini estendido.

Shalit propôs uma forma alternativa de obter tal razão, através do coeficiente angular de uma regressão linear, tendo como variável dependente o preço à vista e 
como variável independente o preço futuro do ativo. Entretanto, duas premissas são exigidas no modelo clássico de regressão linear pelo método dos mínimos quadrados ordinários para que seus estimadores sejam consistentes, nesse caso, para que a razão de hedging fosse ótima: que os preços futuro e os resíduos da regressão não sejam correlacionados, e que os resíduos não sejam correlacionados entre si.

Dessa forma, para garantir a que a razão ótima de hedging obtida pelo modelo clássico de regressão linear fosse consistente, o autor utilizou uma variável instrumental no modelo. A variável instrumental é uma proxy da variável independente que é altamente correlacionada com ela, no entanto, não correlacionada com os resíduos da regressão. A variável instrumental utilizada foi a função de distribuição acumulada dos preços futuro, dado por $\mathrm{F}\left(\mathrm{P}_{\mathrm{f}}\right)$, que segundo Shalit (1995, p. 623) foi originalmente sugerido por Durbin (1954), que construiu a variável instrumental empiricamente, ordenando as observações em ordem ascendente e usou esse ordenamento como um instrumento para resolver o problema de correlação entre a variável independente com os resíduos.

Lien e Shafer (1999, p.103), propuseram determinar a razão ótima de hedging como sugerido por Shalit, no entanto, utilizaram os retornos dos preços à vista e futuro ao invés do nível de preços. Dessa forma, a razão ótima de hedging determinada pela regressão linear, utilizando como variável instrumental a função de distribuição acumulada dos retornos do preço futuro, $F\left(R_{f}\right)$, é dada por:

$$
\mathrm{b}=\frac{\operatorname{cov}\left\{\mathrm{R}_{\mathrm{S}},\left[1-\hat{\mathrm{F}}\left(\mathrm{R}_{\mathrm{f}}\right)\right]^{v-1}\right\}}{\operatorname{cov}\left\{\mathrm{R}_{\mathrm{f}},\left[1-\hat{\mathrm{F}}\left(\mathrm{R}_{\mathrm{f}}\right)\right]^{v-1}\right\}}
$$

Em que:

$\mathrm{R}_{\mathrm{S}}$ : retorno do preço à vista;

$\mathrm{R}_{\mathrm{f}}$ : retorno do preço futuro; 
$\hat{\mathrm{F}}\left(\mathrm{R}_{\mathrm{f}}\right)$ : função da distribuição acumulada dos retornos do preço futuro estimada.

Onde $\hat{\mathrm{F}}\left(\mathrm{R}_{\mathrm{f}}\right)$ é a distribuição empírica e ordenada em ordem ascendente dos retornos do preço futuro.

A eficácia dessa estratégia foi determinada através da equação (3.21), para a qual foi considerado como medida de risco do portfólio hedgeado, o coeficiente de Gini estendido desse, dado pela equação (3.10) e como medida de risco da posição no mercado à vista, o coeficiente de Gini estendido sobre a posição no mercado à vista.

\subsection{Estratégias por Análise de Regressão Linear Condicionada ao Conjunto de Informações}

A acurácia na obtenção da razão ótima de hedging pelo método tradicional de regressão linear determinando-a ou sobre o nível de preços, ou sobre a variação de preços ou sobre a taxa de retorno dos mesmos, passou a ser questionada por alguns autores, pelo fato desse modelo não considerar variáveis importantes na estimação de seus coeficientes. Bell e Kraser (1986) mostraram em seu trabalho que se a variação do preço futuro esperado depende de um conjunto de informações disponíveis previamente, então o modelo tradicional de regressão linear resultará em uma estimativa viesada da razão ótima de hedging.

Em 1984, Hilliard apresentou um trabalho propondo um modelo que corrigia o problema de viés, considerando o retorno não-esperado do preço à vista na equação que define o retorno do portfólio hedgeado. Assim, considerando uma posição comprada no mercado à vista e uma posição vendida no mercado futuro, o retorno do portfólio hedgeado é definido como:

$$
\mathrm{R}_{\mathrm{h}}=\mathrm{R}_{\mathrm{S}}-\frac{\mathrm{Pf}_{0}}{\mathrm{Ps}_{0}} \mathrm{R}_{\mathrm{f}}
$$


Em que:

$\mathrm{R}_{\mathrm{h}}$ : retorno do portfólio hedgeado;

$\mathrm{R}_{\mathrm{S}}$ : retorno do preço à vista;

$\mathrm{R}_{\mathrm{f}}$ : retorno do preço futuro;

$\mathrm{Ps}_{0}$ : preço futuro em $\mathrm{t}_{0}$;

$\mathrm{Pf}_{0}$ : preço futuro em $\mathrm{t}_{0}$.

O autor afirma que o retorno do preço à vista na equação (4.12), pode ser dividido em dois componentes, um componente esperado e outro não-esperado, dessa forma:

$$
R_{h}=E\left(R_{s}\right)+R_{s \bar{n} \text { esp. }}-\frac{P_{f}^{0}}{P_{s}^{0}} R_{f}
$$

Em que:

$\mathrm{R}_{\mathrm{h}}$ : retorno do portfólio hedgeado;

$\mathrm{E}\left(\mathrm{R}_{\mathrm{S}}\right)$ : valor médio ou retorno esperado do preço à vista;

$\mathrm{R}_{\mathrm{S} \overline{\mathrm{n}} \text { esp. }}$ : retorno não-esperado do preço à vista;

$\mathrm{P}_{\mathrm{S}}^{0}:$ preço futuro em $\mathrm{t}_{0}$;

$\mathrm{P}_{\mathrm{f}}^{0}$ : preço futuro em t $\mathrm{t}_{0}$

$\mathrm{R}_{\mathrm{f}}$ : retorno do preço futuro.

Hillard propunha determinar a razão ótima de hedging, minimizando o risco do portfólio hedgeado determinado pela variância dos retornos desse portfólio, $\sigma^{2}\left(\mathrm{R}_{\mathrm{h}}\right)$. Dado que $\sigma^{2}\left[E\left(R_{S}\right)\right]=0, \sigma^{2}\left(R_{h}\right)$ é definido como: 


$$
\sigma^{2}\left(\mathrm{R}_{\mathrm{h}}\right)=\sigma^{2}\left(\mathrm{R}_{\mathrm{s} \overline{\mathrm{n}} \text { esp }}\right)+\left(\frac{\mathrm{P}_{\mathrm{f}}^{0}}{\mathrm{P}_{\mathrm{s}}^{0}}\right)^{2} \sigma^{2}\left(\mathrm{R}_{\mathrm{f}}\right)-2\left(\frac{\mathrm{P}_{\mathrm{f}}^{0}}{\mathrm{P}_{\mathrm{s}}^{0}}\right) \sigma\left(\mathrm{R}_{\mathrm{s} \overline{\mathrm{n}} \text { esp }}, \mathrm{R}_{\mathrm{f}}\right)
$$

Em que:

$\sigma^{2}\left(\mathrm{R}_{\mathrm{h}}\right)$ : variância dos retornos do portfólio hedgeado;

$\sigma^{2}\left(\mathrm{R}_{\mathrm{s} \bar{n}}\right.$ esp $)$ : variância dos retornos não-esperado do preço à vista;

$\mathrm{P}_{\mathrm{S}}^{0}$ : preço futuro em $\mathrm{t}_{0}$

$\mathrm{P}_{\mathrm{f}}^{0}$ : preço futuro em $\mathrm{t}_{0}$;

$\sigma^{2}\left(R_{f}\right)$ : variância dos retornos do preço futuro;

$\sigma\left(\mathrm{R}_{\mathrm{s} \bar{n}}\right.$ esp, $\left.\mathrm{R}_{\mathrm{f}}\right)$ : covariância entre os retornos não-esperado do preço à vista e retornos do preço futuro.

Sendo que equação (4.14) é uma função diferenciável e convexa da variável $\frac{\mathrm{P}_{\mathrm{f}}^{0}}{\mathrm{P}_{\mathrm{S}}^{0}}$, a determinação do ponto de mínimo dessa função com relação a essa variável é dado pelo valor de $\frac{\mathrm{P}_{\mathrm{f}}^{0}}{\mathrm{P}_{\mathrm{S}}^{0}}$, onde a derivada primeira desta função é igual à zero. Dessa forma, sob a premissa de minimizar o risco do portfólio, a razão ótima de hedging derivando $\sigma^{2}\left(\mathrm{R}_{\mathrm{h}}\right)$ em função $\frac{\mathrm{P}_{\mathrm{f}}^{0}}{\mathrm{P}_{\mathrm{S}}^{0}}$ é dada por:

$$
\frac{\mathrm{P}_{\mathrm{f}}^{0}}{\mathrm{P}_{\mathrm{S}}^{0}}=\frac{\sigma\left(\mathrm{R}_{\mathrm{s} \overline{\mathrm{n}} \mathrm{esp} .} ; \mathrm{R}_{\mathrm{f}}\right)}{\sigma^{2}\left(\mathrm{R}_{\mathrm{f}}\right)}
$$

Em que: 
$\sigma\left(R_{s \bar{n}}\right.$ esp,$\left.R_{f}\right)$ : covariância entre os retornos não-esperado do preço à vista e retornos do preço futuro;

$\sigma^{2}\left(R_{f}\right)$ : variância dos retornos do preço futuro.

Myers e Thompson (1989), aproveitando as contribuições do trabalho de Hillard, propuseram solucionar o problema de viés através de um modelo regressão linear condicional, considerando no modelo o preço à vista como variável dependente e o preço futuro e um conjunto de outras variáveis condicionantes, como defasagem do preço à vista e do futuro, volume de exportação da mercadoria, custo de estocagem da mercadoria etc., como variáveis independentes. Baseado em tal modelo, esse trabalho propôs determinar a razão ótima de hedging considerando a defasagem de um período dos preços à vista e futuro sobre o ativo analisado, como variável condicionante. Dessa forma, a razão ótima de hedging é determinada pelo coeficiente angular, $b_{1}$, da equação de regressão, estimado pelo método dos mínimos quadrados ordinários (MQO):

$$
\mathrm{P}_{\mathrm{s}}^{\mathrm{t}}=\alpha+\mathrm{b}_{1} \mathrm{P}_{\mathrm{f}}^{\mathrm{t}}+\mathrm{b}_{2} \mathrm{P}_{\mathrm{s}}^{\mathrm{t}-1}+\mathrm{b}_{3} \mathrm{P}_{\mathrm{f}}^{\mathrm{t}-1}+\varepsilon
$$

Em que:

$\mathrm{P}_{\mathrm{S}}^{\mathrm{t}}$ : preço à vista em $\mathrm{t}$;

$\mathrm{P}_{\mathrm{f}}^{\mathrm{t}}$ : preço futuro em $\mathrm{t}$;

$\mathrm{P}_{\mathrm{S}}^{\mathrm{t}-1}$ : preço à vista em $\mathrm{t}-1$;

$\mathrm{P}_{\mathrm{f}}^{\mathrm{t}-1}$ : preço à vista em $\mathrm{t}-1$;

$b_{2}$ e $b_{3}$ : coeficientes da regressão linear múltipla;

$\varepsilon$ : erro aleatório;

$\mathrm{b}_{1}$ : razão ótima de hedging. 
A eficácia dessa estratégia foi determinada através da equação (3.21), para a qual foi considerado como medida de risco do portfólio hedgeado, a variância dos retornos desse, dado pela equação (3.19) e como medida de risco da posição no mercado à vista, a variância dos retornos do preço à vista.

\subsection{Estratégia por Análise de Regressão Linear Condicionada ao Conjunto de Informações e ao Período de Carregamento}

Alinhado ao objetivo de solucionar o problema de viés apresentado pelo modelo tradicional de regressão linear na determinação da razão ótima de hedging, Viswanath (1993) propõe estimá-la baseado em um modelo de regressão linear condicional, considerando o conjunto de informações disponíveis quando a estratégia de hedging é estruturada, como levantado por Bell e Kraser (1986), além de apresentar uma contribuição incorporando ao modelo o período de carregamento da estratégia, que foi uma questão levantada por Castelino (1990), o qual afirmou ser razoável esperar que a razão de hedging dependesse do período que a estratégia fosse carregada.

Viswanath (op. cit., p.44) considerou a premissa apresentada no trabalho de Myers e Thompson em 1989, de incorporar ao modelo de regressão linear variáveis denominadas condicionantes na estimação dos coeficientes do modelo, nesse caso, da razão ótima de hedging, uma vez que essa é determinada pelo coeficiente angular do modelo. No entanto, o autor não considerou as mesmas variáveis propostas no trabalho deles, e sim a proposição de Fama e French (1987), de utilizar a base atual, que é dada pela diferença entre o preço futuro e o preço à vista em $t$, como variável condicionante no modelo. Fama e French acreditavam que a base atual deveria ser o elemento para prever a variação dos preços à vista e futuro. Ou seja, ela conteria o conjunto de informações que deveriam ser incorporadas ao modelo de regressão para sanar o problema de viés.

O fundamento teórico do trabalho de Viswanath parte do princípio que um agente econômico, mantendo uma unidade de uma commodity no mercado à vista em $t$, sendo $P_{S}^{t}$ seu preço à vista; terá em $t+\tau$, a variação no valor dessa 
commodity dado por $\mathrm{P}_{\mathrm{S}}^{\mathrm{t}+\tau}-\mathrm{P}_{\mathrm{S}}^{\mathrm{t}}$. Se a posição é hedgeada vendendo $\mathrm{b}$ unidades de um contrato futuro com vencimento em $\mathrm{T}$, então a variação no valor do portfólio formado por esses dois ativos será:

$$
R_{h}=\left(P_{s}^{t+\tau}-P_{s}^{t}\right)-b\left(P_{f}^{t+\tau}-P_{f}^{t}\right)
$$

Em que:

$\mathrm{R}_{\mathrm{h}}$ : retorno do portfólio hedgeado;

$\mathrm{P}_{\mathrm{S}}:$ preço à vista;

$\mathrm{P}_{\mathrm{f}}$ : preço futuro.

Assumindo que a variância seja uma medida apropriada de risco, duas alternativas se apresentam por si mesmas: i) o hedger deseja minimizar a variância não condicional de $R_{h}$, que é equivalente a minimizar a variância de $R_{h}$ no tempo ou, ii) o hedger deseja minimizar a variância de $\mathrm{R}_{\mathrm{h}}$, condicionada a todas as informações disponíveis. Conforme afirma o autor, para o propósito de estimação da razão ótima de hedging, a segunda alternativa é a mais apropriada, pelo fato de, se alguma parte de $\mathrm{R}_{\mathrm{h}}$ for conhecida quando a estratégia de hedging for iniciada, então a parte da variação de $\mathrm{R}_{\mathrm{h}}$ com o tempo é irrelevante para o problema.

Dado que a variância dos retornos do portfólio hedgeado, $\sigma^{2}\left(\mathrm{R}_{\mathrm{h}}\right)$, condicionada a todas as informações disponíveis em $\mathrm{t}$, é uma função diferenciável e convexa da variável b, a determinação do ponto de mínimo dessa função com relação a essa variável é dado pelo valor ótimo de b, onde a derivada primeira desta função é igual à zero. Dessa forma:

$$
\mathrm{b}=\frac{\sigma\left(\mathrm{P}_{\mathrm{S}}^{\mathrm{t}+\tau}, \mathrm{P}_{\mathrm{f}}^{\mathrm{t}+\tau}\right)}{\sigma^{2}\left(\mathrm{P}_{\mathrm{f}}^{\mathrm{t}+\tau}\right)}
$$


Em que:

$\sigma\left(\mathrm{P}_{\mathrm{S}}^{\mathrm{t}+\tau}, \mathrm{P}_{\mathrm{f}}^{\mathrm{t}+\tau}\right)$ : covariância entre os componentes não previsíveis dos preços à vista e futuro;

$\sigma^{2}\left(\mathrm{P}_{\mathrm{f}}^{\mathrm{t}+\tau}\right)$ : covariância do componente não previsível do preço futuro.

Viswanath (1993, p. 45), afirma que a razão ótima de hedging determinada pela equação (4.18), pode também ser estimada através do coeficiente angular na regressão entre $\mathrm{P}_{\mathrm{S}}^{\mathrm{t}+\tau}-\mathrm{E}\left(\mathrm{P}_{\mathrm{S}}^{\mathrm{t}+\tau}\right)$ e $\mathrm{P}_{\mathrm{f}}^{\mathrm{t}+\tau}-\mathrm{E}\left(\mathrm{P}_{\mathrm{f}}^{\mathrm{t}+\tau}\right)$ :

$$
\mathrm{P}_{\mathrm{S}}^{\mathrm{t}+\tau}-\mathrm{E}\left(\mathrm{P}_{\mathrm{S}}^{\mathrm{t}+\tau}\right)=\mathrm{a}+\mathrm{b}\left[\mathrm{P}_{\mathrm{f}}^{\mathrm{t}+\tau}-\mathrm{E}\left(\mathrm{P}_{\mathrm{f}}^{\mathrm{t}+\tau}\right)\right]+\varepsilon
$$

Em que:

$\mathrm{P}_{\mathrm{S}}^{\mathrm{t}+\tau}$ : preço à vista em $\mathrm{t}+\tau$;

$\mathrm{E}\left(\mathrm{P}_{\mathrm{S}}^{\mathrm{t}+\tau}\right)$ : preço à vista médio em $\mathrm{t}+\tau$;

$\mathrm{P}_{\mathrm{f}}^{\mathrm{t}+\tau}$ : preço futuro em $\mathrm{t}+\tau$;

$\mathrm{E}\left(\mathrm{P}_{\mathrm{f}}^{\mathrm{t}+\tau}\right)$ : preço futuro médio em $\mathrm{t}+\tau$;

$\varepsilon$ : erro aleatório;

b : razão ótima de hedging.

Contudo é necessário mensurar $\mathrm{E}\left(\mathrm{P}_{\mathrm{S}}^{\mathrm{t}+\tau}\right)$ e $\mathrm{E}\left(\mathrm{P}_{\mathrm{f}}^{\mathrm{t}+\tau}\right)$. Fama e French (1987) apud Viswanath (1993, p. 45), argumentaram que a base atual deveria ter um poder substancial de prever o preço à vista no vencimento e mostraram que este é um fato verdadeiro para muitas commodities, na medida em que a série de preço à vista sofre persistentes choques, principalmente para commodities estocáveis, refletindo na base atual, a qual carrega informações sobre os preços à vista e futuro. Dessa forma: 


$$
\begin{aligned}
& \mathrm{E}\left(\mathrm{P}_{\mathrm{f}}^{\mathrm{t}+\tau}\right)=\mathrm{P}_{\mathrm{f}}^{\mathrm{t}}+\delta_{1}\left(\mathrm{P}_{\mathrm{f}}^{\mathrm{t}}-\mathrm{P}_{\mathrm{s}}^{\mathrm{t}}\right) \\
& \mathrm{E}\left(\mathrm{P}_{\mathrm{s}}^{\mathrm{t}+\tau}\right)=\mathrm{P}_{\mathrm{s}}^{\mathrm{t}}+\delta_{1}\left(\mathrm{P}_{\mathrm{f}}^{\mathrm{t}}-\mathrm{P}_{\mathrm{s}}^{\mathrm{t}}\right)
\end{aligned}
$$

Em que:

$\mathrm{P}_{\mathrm{S}}^{\mathrm{t}}$ : preço à vista em $\mathrm{t}$;

$\mathrm{E}\left(\mathrm{P}_{\mathrm{S}}^{\mathrm{t}+\tau}\right)$ : preço à vista esperado em $\mathrm{t}+\tau$;

$\mathrm{P}_{\mathrm{f}}^{\mathrm{t}}$ : preço futuro em $\mathrm{t}$;

$\mathrm{E}\left(\mathrm{P}_{\mathrm{f}}^{\mathrm{t}+\tau}\right)$ : preço futuro médio em $\mathrm{t}+\tau$;

$\delta_{1}$ : período de carregamento, ou duration, do hedging;

$\delta_{2}$ : período restante para a maturidade do hedging.

Considerando que as estratégias estudadas nesse trabalho foram aplicadas em contratos futuros, pode-se considerar que $\delta_{1}$ é o tempo em que se a estratégia permaneceu sobre o contrato futuro considerado e $\delta_{2} \circ$ tempo restante para a expiração desse contrato.

A estimativa de b pode ser obtida pelo sistema de equações (4.19), (4.20) e (4.21), que Viswanath, afirma ser equivalente a estimá-lo pela seguinte equação de regressão:

$$
\mathrm{P}_{\mathrm{s}}^{\mathrm{t}+\tau}-\mathrm{P}_{\mathrm{s}}^{\mathrm{t}}=\mathrm{a}+\mathrm{b}\left(\mathrm{P}_{\mathrm{f}}^{\mathrm{t}+\tau}-\mathrm{P}_{\mathrm{f}}^{\mathrm{t}}\right)+\mathrm{c}\left(\mathrm{P}_{\mathrm{f}}^{\mathrm{t}}-\mathrm{P}_{\mathrm{s}}^{\mathrm{t}}\right)+\varepsilon
$$

Em que:

$\mathrm{P}_{\mathrm{S}}^{\mathrm{t}+\tau}$ : preço à vista em $\mathrm{t}+\tau$;

$\mathrm{P}_{\mathrm{S}}^{\mathrm{t}}$ : preço à vista em $\mathrm{t}$; 


$$
\begin{aligned}
& \mathrm{P}_{\mathrm{f}}^{\mathrm{t}+\tau}: \text { preço futuro em } \mathrm{t}+\tau ; \\
& \mathrm{P}_{\mathrm{f}}^{\mathrm{t}}: \text { preço futuro em } \mathrm{t} ; \\
& \mathrm{c}: \delta_{2}-\mathrm{b} \delta_{1} ; \\
& \varepsilon: \text { erro aleatório; } \\
& \mathrm{b}: \text { razão ótima de hedging. }
\end{aligned}
$$

A eficácia dessa estratégia foi determinada através da equação (3.21), para a qual foi considerado como medida de risco do portfólio hedgeado, a variância da variação do seu valor, ou lucro, dado pela equação (3.20) e como medida de risco da posição no mercado à vista, a variância da variação do preço à vista.

\subsection{Estratégia por Mínima Variância Condicionada ao Período de Carregamento}

Castelino (1990) apresentou um trabalho no qual propôs determinar a razão ótima de hedging através da minimização da variância dos retornos do portfólio hedgeado, levando em consideração o período em que a estratégia é carregada. De acordo com o autor, o preço futuro e o preço à vista de um ativo, devem convergir à medida que se aproxima a data de expiração do contrato, devendo ser iguais no vencimento. Dessa forma, o período em que se carrega a estratégia é relevante na determinação da razão ótima de hedging.

O autor crítica o procedimento de determinação da razão de hedging através de modelo de regressão linear pelo fato de, segundo ele, esse modelo não produzir uma razão de hedging de uma unidade, quando a estratégia é carregada até o fim do período de maturidade do contrato utilizado como instrumento de hedging, como deveria ser, considerando o fato de convergência entre os preços à vista e futuro; concluindo dessa forma, que o procedimento de obtenção da razão de hedging por regressão é, portanto, não apropriado.

Castelino derivou a razão ótima de hedging considerando como instrumento de hedging um ativo financeiro que tem sua própria maturidade, ou seja, data de 
inicio e fim de negociação (vencimento), como títulos de dívida. Esses títulos caracterizam-se por apresentar data definida de inicio de negociação e data definida para vencimento, e entre elas haver incorporação diária de rentabilidade sobre o preço inicial de negociação, chegando há um determinado preço na data de vencimento. Entretanto, Bhargava e Malhotra (2007, p. 44) afirmaram que ao considerar contratos futuros, que não tem sua própria maturidade, ou seja, que não tem data definida para início de negociação e apenas data definida para expiração do mesmo, a determinação da razão de hedging, proposta por Castelino, resume-se à minimização da variância dos retornos do portfólio hedgeado, definido pela equação (3.19). Dessa forma, derivando essa equação com relação à $b$, a razão ótima de hedging é dada por:

$$
b=\frac{\sigma\left(R_{s}, R_{f}\right)}{\sigma^{2}\left(R_{f}\right)}
$$

Em que:

$\mathrm{R}_{\mathrm{S}}$ : retorno do preço à vista;

$\mathrm{R}_{\mathrm{f}}$ : retorno do preço futuro;

$\sigma\left(R_{S}, R_{f}\right)$ : covariância entre os retornos do preço à vista e retornos do preço futuro;

$\sigma^{2}\left(\mathrm{R}_{\mathrm{f}}\right)$ : variância dos retornos do preço futuro;

b : razão ótima de hedging.

A eficácia dessa estratégia foi determinada através da equação (3.21), para a qual foi considerado como medida de risco do portfólio hedgeado, a variância dos retornos desse, dado pela equação (3.19) e como medida de risco da posição no mercado à vista, a variância dos retornos do preço à vista. 


\section{ANÁLISE DOS RESULTADOS}

\subsection{Obtenção e Tratamento dos Dados}

As variáveis utilizadas no presente trabalho foram os preços à vista e futuro dos ativos analisados, além da taxa básica de juros que remunera os títulos de dívida da economia brasileira, a taxa Selic. Utilizou-se para análise das estratégias seis ativos, sendo quatro ativos agrícolas: açúcar cristal, álcool anidro, café arábica e soja em grão a granel, e dois ativos financeiros: taxa de câmbio comercial de reais por dólar e lbovespa.

As séries históricas dos dados foram obtidas de suas fontes primárias e oficiais de divulgação e disponibilidade pública. Os preços futuros de todos os ativos são disponibilizados pela Bolsa de Mercadorias e Futuro de São Paulo (BM\&F). Os preços à vista dos ativos agrícolas são disponibilizados pelo Centro de Estudos Avançados em Economia Aplicada (CEPEA), da Escola Superior de Agricultura Luiz de Queiroz (ESALQ) da Universidade de São Paulo, e dos ativos financeiros, como taxa de câmbio reais por dólar americano preço de venda - PTAX 800 do Sisbacen e o índice Bovespa em pontos, pelo Banco Central do Brasil, assim como a taxa Selic.

A cotação e divulgação de preços para esses ativos são diárias, exceto para o preço à vista do álcool anidro que é divulgado semanalmente pelo CEPEA. A taxa Selic utilizada foi a de cotação e divulgação diária anualizada na base de 252 dias úteis. A extensão dos dados utilizados está compreendida entre os anos de 2004 e 2006, com registros abrangendo do primeiro dia útil de 2004 ao último dia útil de 2006.

Para a soja, houve a necessidade de se fazer um ajuste na série histórica dos preços futuros anteriores a 27/ago./2004, uma vez que até essa data eles eram divulgados na cotação de US\$/ton. e passaram a ser divulgados na cotação US\$/saca (60 kg). Outro ponto relevante, é que em 2004 não existiam os contratos 
com vencimento em junho e agosto para este ativo, passando a existir após essa data.

Como série de preço futuro para os ativos negociados em reais, utilizou-se os preços divulgados sob a denominação Cotação de ajuste-dia atual pela BM\&F. Essa cotação é exatamente o preço futuro do ativo quando houve negociação no mercado. No entanto, quando não houve negociação do mesmo, a BM\&F através de suas regras específicas de arbitragem, divulga um preço denominado de Cotação de ajuste-dia atual. Tal preço serve para que os indivíduos e instituições que possuam posição em aberto nos contratos consigam marcá-los a mercado. Para os ativos negociados em dólar, o procedimento é o mesmo, no entanto, são convertidos em reais por uma taxa de câmbio adotada pela BM\&F e divulgado sob a denominação Equivalência em Moeda Corrente.

\subsection{Procedimentos de Análise}

As estratégias de hedging estudadas foram analisadas semanalmente, através de janela móvel de dados. Estabeleceu-se, arbitrariamente, a segunda-feira como o dia da semana para se fazer a operação nos contratos futuros e para rebalancear as estratégias, iniciando-se com a primeira segunda-feira útil de 2004 para todos os ativos nos contratos de primeiro vencimento.

Considerou-se a quantidade de 100 registros passados em cada variável preço à vista, futuro e taxa Selic - para cada ativo, abrangendo o registro do último dia útil anterior ao dia da operação ao centésimo registro passado, partindo do pressuposto que o indivíduo ou a instituição não utilizam registros de preço do dia da operação, uma vez que o contrato que está operando está em aberto e em negociação.

Essa janela de dados move-se semanalmente, dessa forma o indivíduo ou a instituição rebalanceia sua estratégia toda semana, considerando os novos últimos dados e descartando os mais antigos, sempre constituindo um conjunto de 100 registros. Caso as segundas-feiras de operação não fossem dias úteis, considerouse as terças-feiras e assim por diante. Esse procedimento de análise foi adotado de 
forma que o indivíduo ou a instituição ficassem sempre com a posição do ativo no mercado à vista hedgeada.

Determinou-se também que nas segundas-feiras úteis, dia de operação, e que antecediam a expiração do contrato de primeiro vencimento, o indivíduo ou a instituição sairiam desse contrato e passariam a operar o próximo vencimento. Esse procedimento evitou que as estratégias fossem contaminadas pela volatilidade dos preços futuros que normalmente ocorre nos últimos dias de negociação do contrato, além de diminuir os custos de transação, principalmente para os produtos agrícolas, os quais ocorreriam caso o contrato fosse levado ao vencimento.

Todavia a constituição de um conjunto com 100 registros não foi possível para todos os ativos. No caso do álcool anidro, pelo fato de o preço à vista ser cotado e divulgado semanalmente, o tamanho do conjunto de dados ficou comprometido uma vez que é necessário utilizar o preço futuro equivalente ao dia do preço à vista para haver coerência. Para alguns outros ativos, houve contrato futuro em que não ocorreu mais de 100 registros de negociação, como pode ser observado pela tabela 5.

Tabela 5 - Número de registros por contrato para cada ativo

\begin{tabular}{|c|c|c|c|c|c|c|c|c|c|c|c|}
\hline \multicolumn{2}{|c|}{ Açúcar } & \multicolumn{2}{|c|}{ Álcool } & \multicolumn{2}{|c|}{ Café Arábica } & \multicolumn{2}{|c|}{ Soja } & \multicolumn{2}{|c|}{ Dólar Comercial } & \multicolumn{2}{|c|}{ Ibovespa } \\
\hline FEV_04 & 155 & FEV_04 & 31 & MAR_04 & 185 & MAR_04 & 134 & FEV_04 & 131 & FEV_04 & 103 \\
\hline ABR_04 & 196 & MAR_04 & 36 & MAI_04 & 226 & ABR_04 & 168 & MAR_04 & 169 & ABR_04 & 85 \\
\hline JUL_04 & 196 & ABR_04 & 35 & JUL_04 & 268 & MAI_04 & 198 & ABR_04 & 192 & JUN_04 & 243 \\
\hline SET_04 & 209 & MAI_04 & 37 & SET_04 & 311 & JUL_04 & 83 & MAI_04 & 203 & AGO_04 & 214 \\
\hline NOV_04 & 232 & JUN_04 & 16 & DEZ_04 & 373 & SET_04 & 95 & JUN_04 & 141 & OUT_04 & 242 \\
\hline FEV_05 & 250 & JUL_04 & 20 & MAR_05 & 275 & NOV_04 & 116 & JUL_04 & 112 & DEZ_04 & 232 \\
\hline ABR_05 & 173 & AGO_04 & 25 & MAI_05 & 174 & MAR_05 & 115 & AGO_04 & 254 & FEV_05 & 174 \\
\hline JUL_05 & 227 & SET_04 & 28 & JUL_05 & 178 & ABR_05 & 135 & SET_04 & 216 & ABR_05 & 80 \\
\hline SET_05 & 181 & OUT_04 & 26 & SET_05 & 276 & MAI_05 & 157 & OUT_04 & 291 & JUN_05 & 230 \\
\hline NOV_05 & 218 & NOV_04 & 30 & DEZ_05 & 292 & JUN_5 & 145 & NOV_04 & 246 & AGO_05 & 238 \\
\hline FEV_06 & 205 & DEZ_04 & 32 & MAR_06 & 325 & JUL_05 & 167 & DEZ_04 & 266 & OUT_05 & 74 \\
\hline ABR_06 & 179 & JAN_05 & 28 & MAI_06 & 195 & AGO_05 & 212 & JAN_05 & 269 & DEZ_05 & 234 \\
\hline JUL_06 & 240 & FEV_05 & 21 & JUL_06 & 237 & SET_05 & 138 & FEV_05 & 180 & FEV_06 & 226 \\
\hline SET_06 & 187 & MAR_05 & 23 & SET_06 & 370 & NOV_05 & 120 & MAR_05 & 253 & ABR_06 & 150 \\
\hline \multirow[t]{21}{*}{ NOV_06 } & 203 & ABR_05 & 24 & DEZ_06 & 303 & MAR_06 & 182 & ABR_05 & 241 & JUN_06 & 149 \\
\hline & & MAI_05 & 26 & & & ABR_06 & 211 & MAI_05 & 149 & AGO_06 & 90 \\
\hline & & JUN_05 & 16 & & & MAI_06 & 229 & JUN_05 & 216 & OUT_06 & 118 \\
\hline & & JUL_05 & 21 & & & JUN_6 & 182 & JUL_05 & 209 & DEZ_06 & 211 \\
\hline & & AGO_05 & 19 & & & JUL_06 & 203 & AGO_05 & 247 & & \\
\hline & & SET_05 & 16 & & & AGO_06 & 199 & SET_05 & 218 & & \\
\hline & & OUT_05 & 18 & & & SET_06 & 220 & OUT_05 & 248 & & \\
\hline & & NOV_05 & 21 & & & NOV_06 & 155 & NOV_05 & 245 & & \\
\hline & & DEZ_05 & 24 & & & & & DEZ_05 & 259 & & \\
\hline & & JAN_06 & 27 & & & & & JAN_06 & 302 & & \\
\hline & & FEV_06 & 21 & & & & & FEV_06 & 254 & & \\
\hline & & MAR_06 & 25 & & & & & MAR_06 & 258 & & \\
\hline & & ABR_06 & 13 & & & & & ABR_06 & 282 & & \\
\hline & & MAI_06 & 12 & & & & & MAI_06 & 223 & & \\
\hline & & JUN_06 & 21 & & & & & JUN 06 & 246 & & \\
\hline & & JUL_06 & 26 & & & & & JUL_06 & 279 & & \\
\hline & & AGO_06 & 29 & & & & & AGO_06 & 215 & & \\
\hline & & SET_06 & 26 & & & & & SET_06 & 237 & & \\
\hline & & OUT_06 & 25 & & & & & OUT_06 & 374 & & \\
\hline & & NOV_06 & 31 & & & & & NOV_06 & 245 & & \\
\hline & & DEZ_06 & 36 & & & & & DEZ_06 & 244 & & \\
\hline
\end{tabular}


Todos os cálculos da razão ótima de hedging e medida de eficácia das estratégias foram realizados utilizando o aplicativo Microsoft Excel e programação em linguagem Visual Basic for Aplication (VBA). Para as estratégias que incorporam o parâmetro de aversão ao risco, foi utilizado o parâmetro de ordem 1.000 escolhido arbitrariamente. Tal escolha foi baseada no propósito de ser um parâmetro que representasse um grau elevado de aversão ao risco e caracterizasse o perfil do hedger.

Os resultados financeiros foram calculados semanalmente por contrato, para cada ativo, sob a ótica das estratégias, conforme apresentado por Figueiredo (2002 p. 15-16):

$$
\text { res. fin. }=\left(\mathrm{ca}_{\mathrm{t}}-\mathrm{ca} \mathrm{t}_{\mathrm{t}-1}\right) * \mathrm{nc} * \mathrm{tc}
$$

Em que:

res. fin : resultado financeiro;

$\mathrm{ca}_{\mathrm{t}}$ : cotação de ajuste em t;

$\mathrm{ca}_{\mathrm{t}-1}$ : cotação de ajuste em t-1;

$n c: n^{\circ}$. de contratos futuro (razão ótima de hedging);

tc : tamanho do contrato futuro.

Adotou-se mensurar os resultados financeiros em $\mathrm{R} \$$ por unidade do ativo negociado. Por isso, foi necessário ajustar a cotação de alguns ativos para essa unidade. Para o açúcar cristal não houve necessidade de ajuste, pois o preço à vista e o preço futuro são cotados e divulgados em $R \$$ saca, com cada saca contendo 50 kg do produto; da mesma forma para o café arábica e para a soja, que têm o preço à vista e o preço futuro, cotados e divulgados em $\mathrm{R} \$ /$ saca, com cada saca contendo $60 \mathrm{~kg}$. Para o lbovespa, também não houve necessidade de ajuste, pois seu preço à vista e preço futuro, são cotados e divulgados em pontos. 
Entretanto, para o ativo álcool anidro e o dólar comercial, houve necessidade de ajuste. Para o álcool o preço à vista é cotado e divulgado em $\mathrm{R} \$ /$ litro, já o preço futuro é cotado e divulgado em $R \$ 1.000$ litros. Dessa forma, utilizou-se para cômputo dos resultados, a cotação em $\mathrm{R} \$ /$ litro para o preço futuro também. Para o dólar comercial, apesar do preço à vista e preço futuro serem cotados e divulgados em R $\$ 1.000$ US\$, optou-se por utilizar a cotação em R\$/US\$ para ambos, padronizando-o com os demais ativos.

Considerou também, que a quantidade do ativo à vista que se quer hedgear, é sempre igual ao tamanho do contrato futuro do ativo em questão.

\subsection{Resultados Obtidos}

O objetivo principal do trabalho é determinar se há uma estratégia superior às demais, dentre as que foram estudadas, para ser utilizada como o melhor instrumento de hedging para os ativos agrícolas analisados. Tal determinação foi feita baseada nos resultados financeiros e nas medidas de eficácia semanal, obtidos por estratégia, para cada ativo utilizado no estudo.

Para a determinação das razões ótimas de hedging e das medidas de eficácia, foram considerados dados ex ante, ou seja, dados históricos anteriores ao dia da operação do contrato. No entanto, a mensuração dos resultados financeiros foi obtida por dados ex post, ou seja, posteriores ao dia da operação, uma vez que esse só é determinado na semana seguinte ou na data da próxima operação do contrato.

Como os contratos não foram levados ao vencimento, o preço à vista não influenciou na mensuração dos resultados financeiros, sendo considerado apenas na determinação da razão ótima de hedging e da eficácia da estratégia. O motivo da não consideração é pelo fato do indivíduo ou instituição sair do contrato na segundafeira anterior ao vencimento do mesmo e começar a operar o contrato com vencimento seguinte. 
Para tornar didática a leitura das tabelas e gráficos apresentados, estabeleceu-se uma nomenclatura para as estratégias, de acordo com a ordem de exposição em que elas aparecem no capítulo 4, conforme apresentado na tabela 6 :

Tabela 6 - Nomenclatura das estratégias

\begin{tabular}{cl}
\hline Estratégia & Nomenclatura \\
\hline Estratégia por Mínima Variância & estrategia_1 \\
Estratégia por Análise de Regressão Linear & estratégia_2 \\
Estratégia por Maximização do Índice de Sharpe & estratégia_3 \\
Estratégia por Maximização da Utilidade Esperada & estratégia_4 \\
$\begin{array}{c}\text { Estratégia por Minimização do Coeficiente de Gini Estendido } \\
\text { Estratégia por Análise de Regressão Linear Condicionada ao } \\
\text { Conjunto de Informações }\end{array}$ & estratégia_5 \\
$\begin{array}{c}\text { Estratégia por Análise de Regressão Linear Condicionada ao } \\
\text { Conjunto de Informações e ao Período de Carregamento } \\
\text { Estratégia por Mínima Variância Condicionada ao Período de } \\
\text { Carregamento }\end{array}$ & estratégia_6 \\
\hline
\end{tabular}

O objetivo principal do trabalho é analisar as estratégias de hedging sobre os ativos agrícolas, no entanto, optou-se por analisar também dois ativos financeiros com o propósito de identificar se os resultados dos ativos agrícolas diferem dos financeiros, quando analisados sobre uma mesma estratégia. As etapas de análise do trabalho dividem-se em:

i) Mensuração dos resultados financeiros por estratégia para cada ativo;

ii) A análise de variância dos resultados financeiros médios por estratégia, para cada ativo, com o propósito de avaliar se há diferença estatisticamente significativa entre elas;

iii) A análise de variância dos resultados financeiros médios por ativo, por estratégia, visando analisar se a diferença entre eles é estatisticamente significativa; 
iv) A análise das medidas de eficácia entre estratégias, sob o mesmo ativo, na determinação de superioridade de uma com relação às demais.

v) A identificação da eventual superioridade de uma estratégia sobre as demais, para um mesmo ativo.

A análise de variância (ANOVA) foi realizada para um único fator, sobre duas óticas diferentes. Primeiro sobre a ótica de cada ativo para diferentes estratégias. Nesse caso, o fator sobre o qual poderia justificar diferenças entre as médias dos resultados financeiros obtidos das amostras, extraídas independentemente, são as diferentes estratégias analisadas. Segundo, sobre a ótica de cada estratégia para diferentes ativos. Nesse caso o fator sobre o qual poderia justificar diferenças entre as médias dos resultados financeiros obtidos das amostras, extraídas independentemente, são os diferentes ativos analisados.

A determinação da razão ótima de hedging partiu da premissa de que o indivíduo tem posição comprada no ativo no mercado à vista, portanto, para hedgear tal posição, posiciona-se vendido em contratos no mercado futuro, sendo que a quantidade ótima a se posicionar nesses contratos é determinada pela estratégia adotada.

Os resultados financeiros foram mensurados semanalmente, de acordo com o método de análise proposto no trabalho, através da equação 5.1. Os resultados financeiros por contrato foram determinados somando-se os ganhos ou perdas, obtidos pelas operações semanais, desde o início da operação do contrato até a segunda-feira que antecedeu o vencimento do mesmo. Uma vez determinado os resultados por contrato, somaram-se todos os contratos operados dentro do período de análise considerado, determinando-se o resultado financeiro total que o hedger obteria, por ativo, sob a ótica de cada estratégia.

Para análise de variância foram extraídas amostras aleatórias de tamanho 40 , sobre o conjunto total dos resultados financeiros obtidos semanalmente pelas operações dos contratos. 


\subsection{Análise de Variância por Ativo}

O propósito dessa análise é identificar estatisticamente se há diferenças significativas entre os resultados financeiros médios, obtidos sobre as amostras de tamanho 40, que sejam justificados pela estratégia adotada, para o mesmo ativo.

\subsubsection{Açúcar Cristal}

O tamanho do contrato utilizado no cômputo do resultado financeiro, tc, foi o tamanho padrão negociado na BM\&F, ou seja, 270 sacas com $50 \mathrm{~kg}$ por saca. Os resultados financeiros obtidos pelas estratégias para o açúcar cristal foram todos negativos, indicando prejuízo financeiro para o produtor agrícola, como pode ser observado pela tabela 7 .

Tabela 7 - Resultados financeiros por vencimento para o açúcar cristal (valores em $R \$$ )

\begin{tabular}{|c|c|c|c|c|c|c|c|c|}
\hline Contratos & estrategia_1 & estrategia_2 & estrategia_3 & estrategia_4 & estrategia_5 & estrategia_6 & estrategia_7 & estrategia_8 \\
\hline FEV_04 & 2,18 & 2,20 & 0,03 & 1,17 & 23,94 & $(1,93)$ & $(8,57)$ & 1,81 \\
\hline ABR_04 & $(190,17)$ & $(192,12)$ & $(3,85)$ & $(179,21)$ & 46,45 & $(230,62)$ & $(179,81)$ & $(176,13)$ \\
\hline JUL_04 & $(755,12)$ & $(762,83)$ & $(38,55)$ & $(650,54)$ & $(533,23)$ & $(778,52)$ & $(779,62)$ & $(656,67)$ \\
\hline SET_04 & $(22,79)$ & $(23,02)$ & $(0,79)$ & $(20,06)$ & $(80,64)$ & $(39,51)$ & $(15,92)$ & $(25,85)$ \\
\hline NOV_04 & $(29,30)$ & $(29,60)$ & $(4,55)$ & $(35,88)$ & $(26,20)$ & $(25,88)$ & $(34,13)$ & $(35,44)$ \\
\hline FEV_05 & $(46,66)$ & $(47,14)$ & $(0,96)$ & $(46,61)$ & $(66,45)$ & $(71,77)$ & $(45,08)$ & $(44,35)$ \\
\hline ABR_05 & $(115,41)$ & $(116,59)$ & $(1,03)$ & $(103,78)$ & $(48,71)$ & $(118,11)$ & $(124,92)$ & $(104,98)$ \\
\hline JUL_05 & 448,50 & 453,08 & 27,99 & 387,93 & $1.103,11$ & 498,23 & 499,24 & 395,33 \\
\hline SET_05 & $(1.293,13)$ & $(1.306,32)$ & $(12,43)$ & $(1.040,33)$ & $(36,63)$ & $(1.342,62)$ & $(1.266,86)$ & $(1.044,88)$ \\
\hline NOV_05 & $(23,30)$ & $(23,54)$ & $(1,82)$ & $(18,14)$ & $(117,24)$ & $(24,84)$ & $(29,76)$ & $(17,92)$ \\
\hline FEV_-06 & $(1.179,45)$ & $(1.191,49)$ & $(104,96)$ & $(1.020,21)$ & $(793,06)$ & $(1.276,87)$ & $(1.191,85)$ & $(1.040,31)$ \\
\hline ABR_06 & $(469,78)$ & $(474,57)$ & $(99,78)$ & $(389,70)$ & $(675,97)$ & $(568,45)$ & $(437,96)$ & $(381,26)$ \\
\hline JUL_06 & $(144,55)$ & $(146,03)$ & $(9,51)$ & $(129,20)$ & $(170,97)$ & $(148,69)$ & $(146,05)$ & $(126,90)$ \\
\hline SET_06 & $(166,06)$ & $(167,76)$ & $(10,90)$ & $(139,65)$ & $(270,55)$ & $(136,11)$ & $(223,10)$ & $(147,28)$ \\
\hline $\mathrm{NOV}_{-}^{-} 06$ & $(227,80)$ & $(230,13)$ & $(33,66)$ & $(198,14)$ & $(39,64)$ & $(234,88)$ & $(214,11)$ & $(195,74)$ \\
\hline Total & $(4.212,84)$ & $(4.255,83)$ & $(294,77)$ & $(3.582,33)$ & $(1.685,78)$ & $(4.500,57)$ & $(4.198,51)$ & $(3.600,57)$ \\
\hline
\end{tabular}

Os resultados financeiros negativos são coerentes com a premissa de assumir uma posição vendida em contratos no mercado futuro para hedgear uma posição comprada no ativo no mercado à vista, quando a série de preços apresenta tendência de alta. Nota-se pelo gráfico 5 , que a série de preços à vista e futuro para o ativo açúcar cristal apresentaram tal tendência em praticamente toda a extensão do período analisado, com exceção apenas para curtos períodos entre os contratos de abril a julho de 2005 e os contratos de abril a novembro de 2006. Dado a tendência dos preços apresentada, contabilizaram-se mais resultados negativos que positivos, por vencimento de contrato. 
O gráfico 5 mostra a série de preços à vista e futuro semanais, no dia da operação, encadeada por contrato para o açúcar cristal.

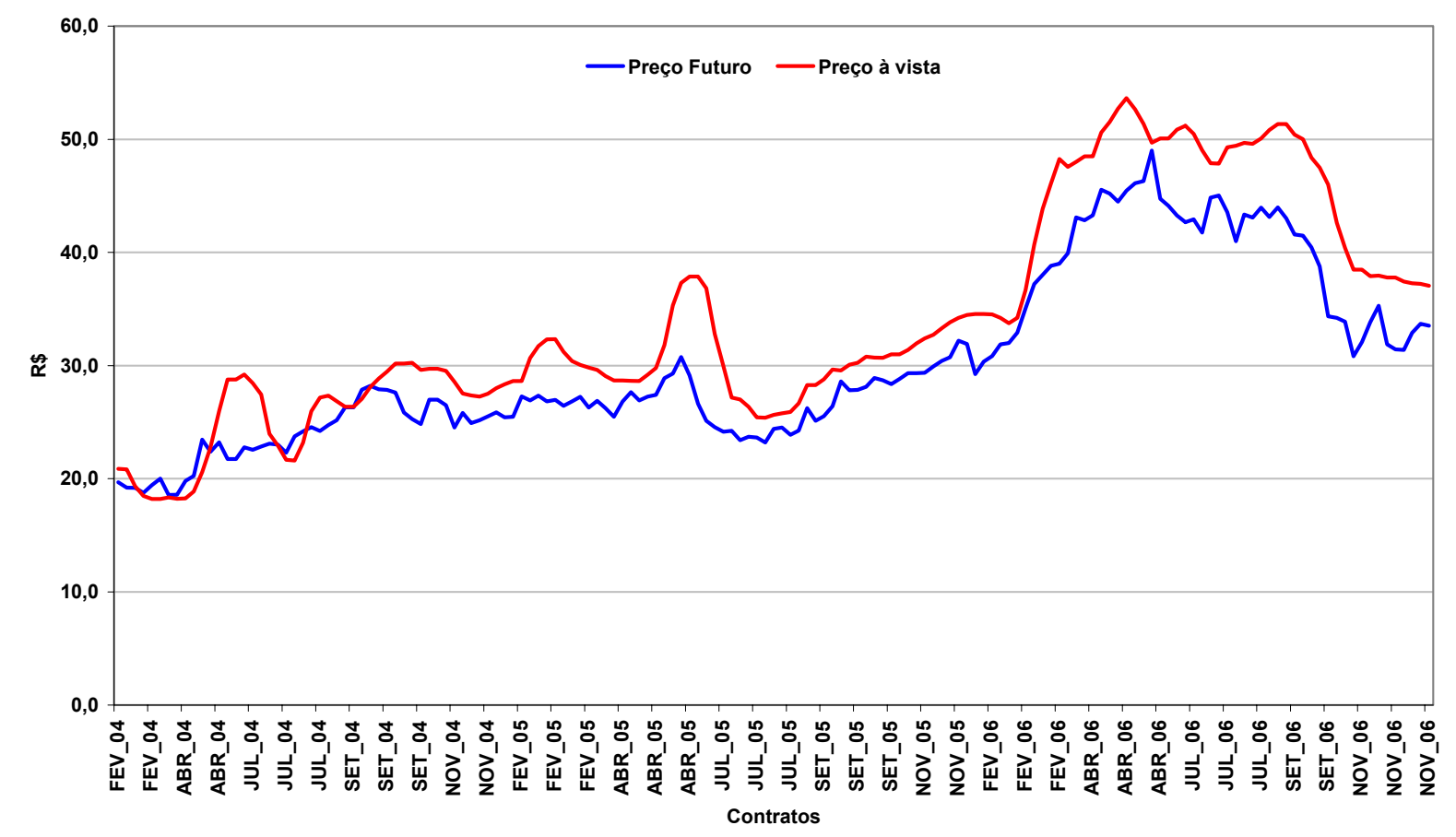

Gráfico 5 - Série de preços à vista e futuro do açúcar cristal Fonte: BM\&F e CEPEA

A análise de variância para o ativo açúcar cristal aceitou a hipótese nula, apontando que não há diferença estatisticamente significativa entre os resultados financeiros médios obtidos sobre as amostras extraídas das estratégias, como pode ser comprovado pela tabela 8 .

Tabela 8 - Análise de variância de um fator para o açúcar cristal

\begin{tabular}{lcccccc}
\hline ANOVA - Fator único & & & & & & \\
\hline Fonte da variação & $S Q$ & $g l$ & $M Q$ & $F$ & valor-P & F critico \\
\hline Entre grupos & $226.577,04$ & 7 & $32.368,15$ & 1,16 & 0,33 & 2,04 \\
Dentro dos grupos & $8.723 .817,29$ & 312 & $27.960,95$ & & & \\
& & & & & & \\
Total & $8.950 .394,34$ & 319 & & & \\
\hline
\end{tabular}

\subsection{2. Álcool Anidro}

O tamanho do contrato utilizado no cômputo do resultado financeiro, tc , foi o tamanho padrão negociado na BM\&F, ou seja, 30 metros cúbicos à $20^{\circ}$ Celsius. Os resultados financeiros obtidos pelas estratégias para o álcool anidro foram todos 
positivos, indicando lucro financeiro para o produtor agrícola, como pode ser observado pela tabela 9 .

Tabela 9 - Resultados financeiros por vencimento para o álcool anidro (valores em $\mathrm{R} \$$ )

\begin{tabular}{|c|c|c|c|c|c|c|c|c|}
\hline Contratos & estrategia_1 & estrategia_2 & estrategia_3 & estrategia_4 & estrategia_5 & estrategia_6 & estrategia_7 & estrategia_8 \\
\hline FEV_04 & $1.664,78$ & $1.681,77$ & 14,77 & $1.902,47$ & 18,60 & $1.566,99$ & $1.581,77$ & $1.844,16$ \\
\hline MAR_04 & $1.975,95$ & $1.996,11$ & 219,28 & $1.873,38$ & $(6,74)$ & $2.046,12$ & $1.987,42$ & $1.866,49$ \\
\hline ABR_04 & $(1.529,74)$ & $(1.545,35)$ & $(330,34)$ & $(1.419,00)$ & 112,69 & $(1.532,01)$ & $(1.656,77)$ & $(1.416,97)$ \\
\hline MAI 04 & 812,04 & 820,32 & 66,40 & 623,37 & 69,80 & 785,22 & 866,54 & 624,83 \\
\hline JUN_04 & $1.113,31$ & $1.132,04$ & 46,17 & $1.542,34$ & $(149,41)$ & 900,20 & $1.820,12$ & $1.498,66$ \\
\hline JUL 04 & 495,72 & 501,49 & 24,54 & 741,58 & $(184,61)$ & 641,78 & 652,57 & 709,72 \\
\hline AGO_04 & $(1.260,96)$ & $(1.273,81)$ & $(189,50)$ & $(1.790,23)$ & $(2.765,13)$ & $(1.309,79)$ & $(1.301,65)$ & $(1.815,16)$ \\
\hline SET_04 & 105,04 & 106,11 & 0,80 & 116,56 & 101,37 & 92,49 & 126,43 & 122,20 \\
\hline OUT_04 & 248,77 & 251,31 & 24,24 & 284,93 & $(1.610,48)$ & 150,17 & 197,76 & 288,05 \\
\hline NOV_04 & $(1.457,97)$ & $(1.472,85)$ & $(15,72)$ & $(1.607,70)$ & $(4.395,22)$ & $(1.431,18)$ & $(1.498,16)$ & $(1.624,17)$ \\
\hline DEZ 04 & $4.430,77$ & $4.475,98$ & 139,79 & $5.068,05$ & $6.455,02$ & $4.379,35$ & $4.427,36$ & $5.068,44$ \\
\hline JAN_05 & $(258,31)$ & $(260,95)$ & $(7,09)$ & $(338,33)$ & $(229,74)$ & $(257,06)$ & $(295,73)$ & $(327,96)$ \\
\hline FEV_05 & 82,89 & 83,73 & 3,29 & 78,41 & $(14,51)$ & 94,70 & 68,00 & 77,11 \\
\hline MAR_05 & 20,86 & 21,15 & 0,46 & 16,05 & $(19,35)$ & 24,45 & 11,34 & 18,41 \\
\hline ABR 05 & 50,51 & 51,03 & 1,45 & 48,26 & 137,61 & 59,33 & 54,17 & 53,02 \\
\hline MAI_05 & $(4,26)$ & $(4,31)$ & $(1,46)$ & $(3,82)$ & 46,26 & 12,13 & $(1,60)$ & $(11,34)$ \\
\hline JUN_05 & $(54,13)$ & $(55,03)$ & 2,09 & $(64,71)$ & 103,41 & $(40,46)$ & $(104,05)$ & $(51,00)$ \\
\hline JUL_05 & 237,37 & 240,23 & 7,83 & 181,64 & 331,20 & 424,88 & 285,62 & 199,57 \\
\hline AGO 05 & 82,11 & 83,15 & 6,29 & 123,24 & 383,91 & 89,49 & 100,73 & 123,33 \\
\hline SET_05 & 19,46 & 19,65 & 1,17 & 23,56 & $(38,15)$ & 16,21 & 20,35 & 25,95 \\
\hline OUT_05 & 412,12 & 417,55 & 6,18 & 471,38 & $1.174,83$ & 368,34 & 422,46 & 455,59 \\
\hline NOV_05 & $1.775,92$ & $1.796,04$ & 15,34 & $2.027,80$ & $3.799,35$ & $1.708,74$ & $1.858,70$ & $2.042,19$ \\
\hline DEZ 05 & $(1.111,22)$ & $(1.122,38)$ & $(9,35)$ & $(1.307,10)$ & $(3.906,81)$ & $(1.012,89)$ & $(1.128,08)$ & $(1.326,25)$ \\
\hline JAN 06 & 224,19 & 226,48 & 3,06 & 253,33 & 656,27 & 204,99 & 255,12 & 261,02 \\
\hline FEV 06 & $(129,35)$ & $(130,67)$ & $(1,95)$ & $(151,40)$ & $(589,81)$ & $(115,67)$ & $(112,75)$ & $(150,59)$ \\
\hline MAR_06 & $(870,88)$ & $(879,80)$ & $(13,32)$ & $(910,64)$ & 227,78 & $(821,73)$ & $(726,51)$ & $(921,06)$ \\
\hline ABR 06 & $(96,25)$ & $(97,32)$ & 0,66 & $(118,43)$ & $(211,41)$ & $(26,39)$ & $(37,49)$ & $(100,30)$ \\
\hline MAl 06 & $1.185,35$ & $1.197,45$ & 36,43 & $1.139,70$ & $2.749,83$ & $1.145,73$ & $1.199,58$ & $1.142,56$ \\
\hline JUN 06 & $1.088,59$ & $1.099,82$ & 52,98 & $1.119,56$ & 286,61 & $1.085,38$ & 969,91 & $1.122,05$ \\
\hline JUL_06 & 666,34 & 673,14 & 35,15 & 693,95 & 373,03 & 653,15 & 643,37 & 691,83 \\
\hline AGO 06 & 240,16 & 242,61 & 10,62 & 267,49 & $1.054,55$ & 355,29 & 223,07 & 267,19 \\
\hline SET 06 & $(200,73)$ & $(202,78)$ & $(7,42)$ & $(212,95)$ & 26,30 & $(190,14)$ & $(258,04)$ & $(223,39)$ \\
\hline OUT_06 & 197,10 & 199,11 & 13,18 & 201,21 & $(28,35)$ & 177,08 & 221,53 & 200,20 \\
\hline NOV_06 & 189,33 & 191,27 & 7,53 & 200,39 & $(22,12)$ & 216,44 & 211,50 & 199,69 \\
\hline DEZ 06 & 755,36 & 763,06 & 31,54 & 787,92 & 4,94 & 736,09 & 849,38 & 787,41 \\
\hline Total & $11.100,22$ & $11.225,36$ & 195,12 & $11.862,28$ & $3.941,53$ & $11.197,43$ & $11.933,97$ & $11.721,52$ \\
\hline
\end{tabular}

Os resultados financeiros positivos são coerentes com a premissa de assumir uma posição vendida em contrato no mercado futuro para hedgear uma posição comprada no ativo no mercado à vista, quando a série de preços apresenta tendência de queda. Nota-se pelo gráfico 6, que apesar da série de preços à vista e futuro para o álcool anidro terem apresentados tendência de alta ao longo do período estudado, ao segmentar tal período em intervalos menores, observou-se que houve três intervalos de queda entre os contratos de fevereiro a abril de 2004 , entre os contratos de novembro de 2004 a junho de 2005 e entre os contratos de março a dezembro de 2006. Além do fato de que as oscilações do preço futuro dentro dos períodos de alta foram significativas, pois as ligeiras quedas nesse preço determinaram resultados financeiros positivos. Portanto, como observado, os intervalos de queda foram mais significativos na mensuração dos resultados financeiros, contabilizando mais resultados positivos que negativos, por vencimento de contrato. 
O gráfico 6 mostra a série de preços à vista e futuro semanais, no dia da operação, encadeada por contrato para o álcool anidro.

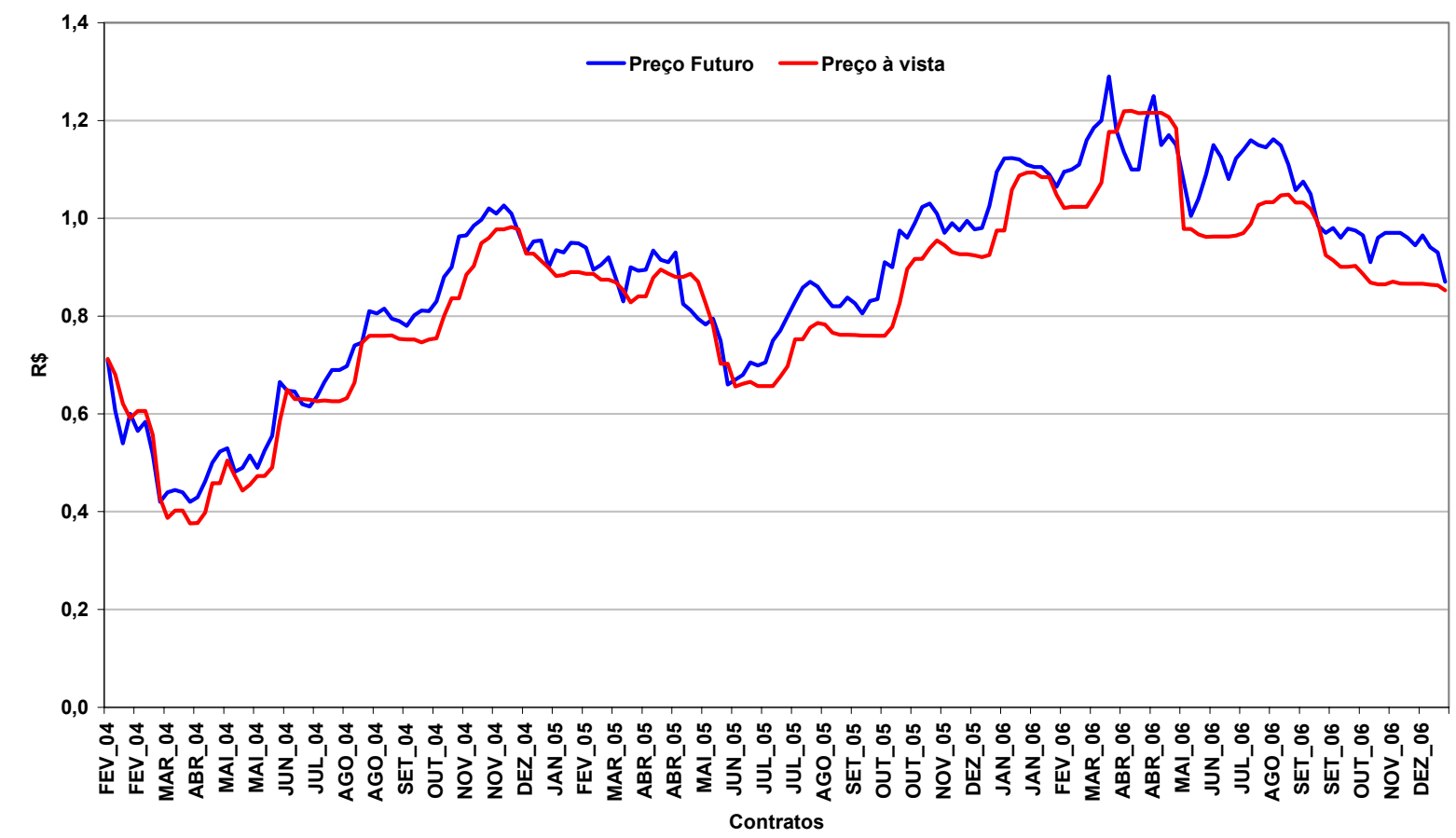

Gráfico 6 - Série de preços à vista e futuro do álcool anidro Fonte: BM\&F e CEPEA

A análise de variância para o álcool anidro aceitou a hipótese nula, apontando que não há diferença estatisticamente significativa entre os resultados financeiros médios obtidos sobre as amostras extraídas das estratégias, como pode ser comprovado pela tabela 10 .

Tabela 10 - Análise de variância de um fator para o álcool anidro

\begin{tabular}{|c|c|c|c|c|c|c|}
\hline \multicolumn{7}{|c|}{ ANOVA - Fator único } \\
\hline Fonte da variação & $S Q$ & $g l$ & $\overline{M Q}$ & $\bar{F}$ & valor-P & F crítico \\
\hline Entre grupos & $3.882 .285,33$ & $\frac{7}{7}$ & $554.612,19$ & 1,01 & 0,42 & 2,04 \\
\hline Dentro dos grupos & $170.925 .888,58$ & 312 & $547.839,39$ & & & \\
\hline Total & $174.808 .173,90$ & 319 & & & & \\
\hline
\end{tabular}

\subsubsection{Café Arábica}

O tamanho do contrato utilizado no cômputo do resultado financeiro, tc , foi o tamanho padrão negociado na BM\&F, ou seja, 100 sacas com $60 \mathrm{~kg}$ líquidos por saca. Os resultados financeiros obtidos pelas estratégias para o café arábica foram 
todos negativos, indicando prejuízo financeiro para o produtor agrícola, como pode ser observado pela tabela 11.

Tabela 11 - Resultados financeiros por vencimento do café arábica (valores em $R \$$ )

\begin{tabular}{|c|c|c|c|c|c|c|c|c|}
\hline Contratos & estrategia_1 & estrategia_2 & estrategia_3 & estrategia_4 & estrategia_5 & estrategia_6 & estrategia_7 & estrategia_8 \\
\hline MAR_04 & $(2.321,84)$ & $(2.345,54)$ & $(63,12)$ & $(2.817,33)$ & $(391,00)$ & $(2.333,80)$ & $(2.394,66)$ & $(2.822,00)$ \\
\hline MAI_04 & 252,27 & 254,85 & 11,30 & 291,12 & 333,66 & 268,51 & 246,96 & 295,42 \\
\hline JUL_04 & 932,20 & 941,71 & $(116,96)$ & 899,20 & 640,59 & $1.120,61$ & 970,95 & 921,02 \\
\hline SET_04 & $(955,49)$ & $(965,24)$ & $(106,47)$ & $(1.153,36)$ & $(818,88)$ & $(948,40)$ & $(969,55)$ & $(1.150,85)$ \\
\hline DEZ_04 & $(4.759,30)$ & $(4.807,86)$ & $(223,11)$ & $(5.569,95)$ & $(7.880,50)$ & $(5.011,80)$ & $(4.853,03)$ & $(5.572,15)$ \\
\hline MAR_05 & $(2.917,29)$ & $(2.947,06)$ & $(310,27)$ & $(3.787,87)$ & $(2.540,58)$ & $(2.932,17)$ & $(3.007,56)$ & $(3.792,86)$ \\
\hline MAI_05 & $4.228,21$ & $4.271,36$ & 365,23 & $5.115,26$ & $5.746,56$ & $4.322,70$ & $4.354,82$ & $5.129,75$ \\
\hline JUL_05 & $4.616,94$ & $4.664,05$ & 274,21 & $5.565,23$ & $6.234,19$ & $4.580,09$ & $4.735,11$ & $5.570,91$ \\
\hline SET_05 & $2.460,87$ & $2.485,98$ & 142,94 & $2.943,58$ & $2.006,90$ & $2.643,39$ & $2.489,01$ & $2.922,03$ \\
\hline DEZ_05 & $(3.077,60)$ & $(3.109,01)$ & $(254,46)$ & $(3.598,32)$ & $(5.465,24)$ & $(3.053,65)$ & $(3.181,37)$ & $(3.587,03)$ \\
\hline MAR_06 & $1.530,14$ & $1.545,75$ & 56,98 & $1.798,15$ & $2.270,18$ & $1.593,87$ & $1.660,91$ & $1.812,24$ \\
\hline MAI_06 & $(304,79)$ & $(307,90)$ & $(9,01)$ & $(347,74)$ & $(266,86)$ & $(276,50)$ & $(304,04)$ & $(343,39)$ \\
\hline JUL_06 & 648,70 & 655,31 & 20,81 & 720,00 & 177,92 & 697,58 & 716,97 & 713,26 \\
\hline SET_06 & $(10,54)$ & $(10,65)$ & 1,86 & $(23,61)$ & $(1.263,40)$ & $(23,26)$ & 14,08 & $(19,27)$ \\
\hline DEZ_06 & $(3.235,22)$ & $(3.268,23)$ & $(91,24)$ & $(3.824,18)$ & 322,92 & $(3.288,73)$ & $(3.410,39)$ & $(3.803,78)$ \\
\hline Total & $(2.912,75)$ & $(2.942,47)$ & $(301,33)$ & $(3.789,84)$ & $(893,53)$ & $(2.641,55)$ & $(2.931,78)$ & $(3.726,68)$ \\
\hline
\end{tabular}

Os resultados financeiros negativos são coerentes com a premissa de assumir uma posição vendida em contrato no mercado futuro para hedgear uma posição comprada no ativo no mercado à vista, quando a série de preços apresenta tendência de alta. Nota-se pelo gráfico 7 , que a série de preços à vista e futuro para o café arábica, não apresentaram tendência de aumento ou queda ao longo do período analisado. No entanto, ao considerar intervalos menores, observa-se que entre os contratos de março de 2004 a março de 2005, entre os contratos de setembro de 2005 a março de 2006 e entre os contratos de setembro a dezembro de 2006, houve uma tendência de alta dos preços, e entre os contratos de março a setembro de 2005 e entre os contratos de março a setembro de 2006, houve uma tendência de queda dos preços. Outro fato é que mesmo dentro dos períodos de queda, as oscilações do preço futuro podem ter sido significativos na mensuração do resultado financeiro, apresentando prejuízo. Dessa forma, dado que os intervalos de alta foram maiores que os de queda, contabilizaram-se mais resultados negativos que positivos, por vencimento de contrato.

O gráfico 7 mostra a série de preços à vista e futuro semanais, no dia da operação, encadeada por contrato para o café arábica. 


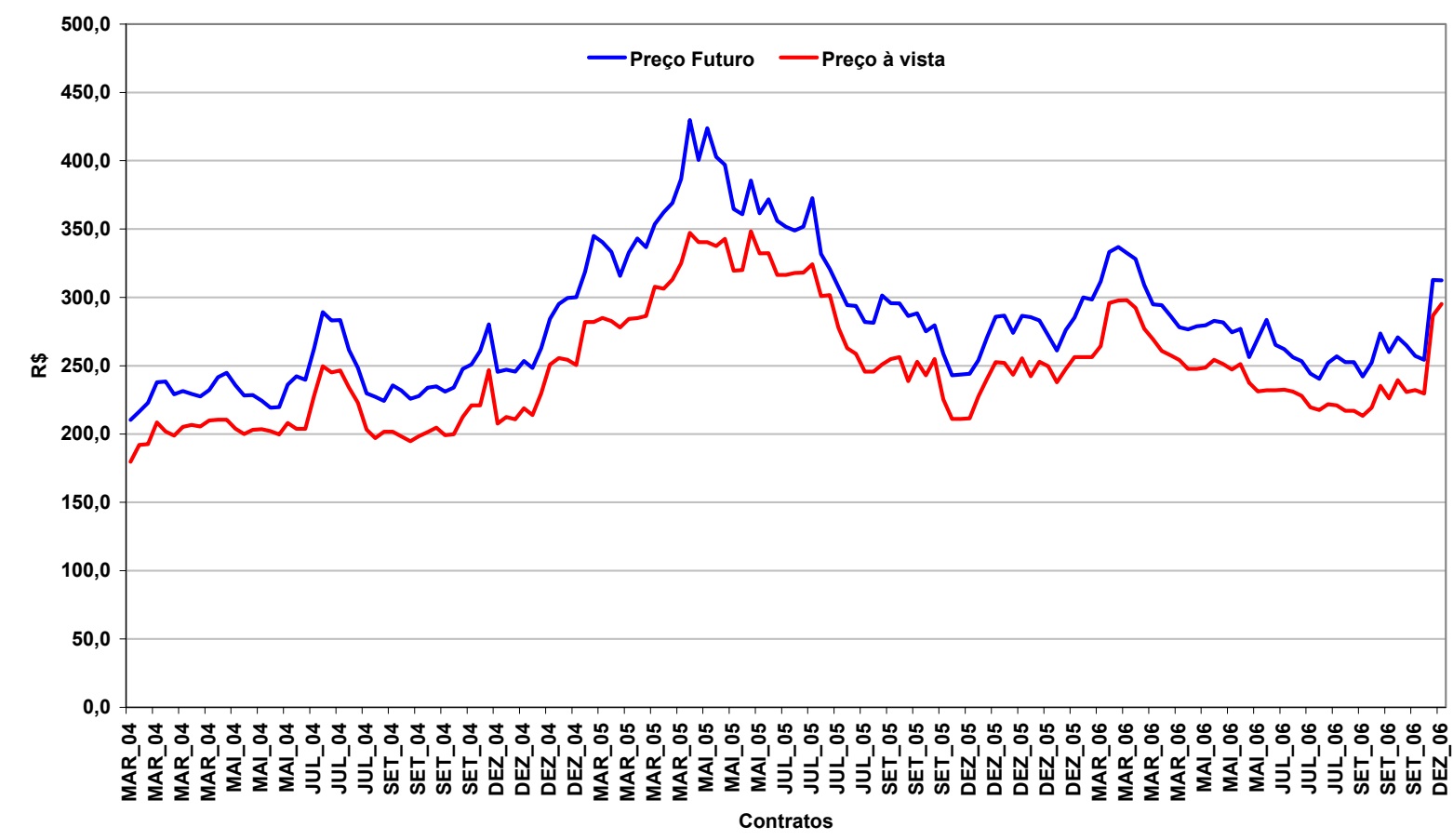

Gráfico 7 - Série de preços à vista e futuro para o café arábica Fonte: BM\&F e CEPEA

A análise de variância para o café arábica aceitou a hipótese nula, apontando que não há diferença estatisticamente significativa entre os resultados financeiros médios obtidos sobre as amostras extraídas das estratégias, como pode ser comprovado pela tabela 12 .

Tabela 12 - Análise de variância de um fator para o café arábica

\begin{tabular}{lcccccc}
\hline ANOVA - Fator único & \multicolumn{1}{c}{ gl } & $M Q$ & $F$ & valor-P & F crítico \\
\hline Fonte da variação & $S Q$ & 7 & $1.111 .210,91$ & 0,99 & 0,44 & 2,04 \\
\hline Entre grupos & $7.778 .476,36$ & 312 & $1.122 .672,38$ & & \\
Dentro dos grupos & $350.273 .781,52$ & & & & \\
& & & & & & \\
Total & $358.052 .257,89$ & 319 & & & \\
\hline
\end{tabular}

\subsubsection{Soja}

O tamanho do contrato utilizado no cômputo do resultado financeiro, tc , foi o tamanho padrão negociado na BM\&F, ou seja, 450 sacas com $60 \mathrm{~kg}$ por saca em grãos a granel. Os resultados financeiros obtidos pelas estratégias para a soja foram 
todos positivos, indicando lucro financeiro para o produtor agrícola, como pode ser observado pela tabela 13 .

Tabela 13 - Resultados financeiros por vencimento da soja (valores em $R \$$ )

\begin{tabular}{|c|c|c|c|c|c|c|c|c|}
\hline Contratos & estrategia_1 & estrategia_2 & estrategia_3 & estrategia_4 & estrategia_5 & estrategia_6 & estrategia_7 & estrategia_8 \\
\hline MAR_04 & $(183,42)$ & $(185,29)$ & $(1,93)$ & $(170,83)$ & $(622,60)$ & $(171,82)$ & $(182,66)$ & $(181,35)$ \\
\hline ABR_04 & $(64,40)$ & $(65,06)$ & 0,09 & $(57,68)$ & 782,90 & $(65,71)$ & $(55,62)$ & $(66,50)$ \\
\hline MAI_04 & $(401,72)$ & $(405,82)$ & $(17,66)$ & $(395,01)$ & $(501,33)$ & $(423,30)$ & $(420,57)$ & $(391,45)$ \\
\hline JUL_04 & $1.445,24$ & $1.467,60$ & 45,50 & $1.614,03$ & $1.930,43$ & $1.657,90$ & $1.610,64$ & $1.618,31$ \\
\hline SET_04 & $2.277,12$ & $2.316,25$ & 34,06 & $2.670,41$ & $1.684,67$ & $2.578,63$ & $2.430,73$ & $2.636,66$ \\
\hline NOV_04 & 699,99 & 707,45 & 6,97 & 776,27 & $1.504,13$ & 823,52 & 747,84 & 747,70 \\
\hline MAR_05 & 708,91 & 718,45 & 29,43 & 685,40 & 97,48 & 679,28 & 761,32 & 669,46 \\
\hline ABR_05 & $(2.384,56)$ & $(2.408,89)$ & $(29,33)$ & $(2.576,66)$ & $(54,10)$ & $(2.377,68)$ & $(2.540,42)$ & $(2.557,76)$ \\
\hline MAI_05 & 843,35 & 851,96 & 70,16 & 870,50 & 783,75 & 842,37 & 806,83 & 874,56 \\
\hline JUN_05 & 410,83 & 415,02 & 16,27 & 419,82 & 95,95 & 399,42 & 403,46 & 417,12 \\
\hline JUL_05 & $(404,61)$ & $(408,73)$ & $(9,99)$ & $(409,25)$ & $(478,70)$ & $(394,78)$ & $(399,89)$ & $(409,49)$ \\
\hline AGO_05 & 439,96 & 444,45 & 5,44 & 510,72 & $1.394,42$ & 329,97 & 355,86 & 524,47 \\
\hline SET_05 & 707,31 & 714,53 & 27,27 & 710,10 & $(21,41)$ & 709,09 & 714,40 & 710,20 \\
\hline NOV_05 & $1.030,74$ & $1.041,07$ & 34,94 & $1.111,17$ & $1.026,73$ & $1.002,99$ & $1.121,13$ & $1.108,24$ \\
\hline MAR_06 & $(93,30)$ & $(94,44)$ & 5,55 & $(131,29)$ & 253,72 & $(2,48)$ & $(99,41)$ & $(107,96)$ \\
\hline ABR_06 & 101,20 & 102,23 & 1,66 & 102,98 & 89,38 & 107,75 & 109,55 & 103,05 \\
\hline MAI_06 & 517,49 & 522,77 & 13,07 & 540,52 & 322,50 & 533,55 & 537,00 & 540,58 \\
\hline JUN_06 & $(772,19)$ & $(780,06)$ & $(31,16)$ & $(810,30)$ & $(565,27)$ & $(805,01)$ & $(781,92)$ & $(810,61)$ \\
\hline JUL_06 & $(226,10)$ & $(228,40)$ & $(5,24)$ & $(223,08)$ & $(178,04)$ & $(228,55)$ & $(225,02)$ & $(224,13)$ \\
\hline AGO_06 & $(4,74)$ & $(4,79)$ & $(0,03)$ & $(5,80)$ & $(0,23)$ & 6,51 & $(1,72)$ & $(5,04)$ \\
\hline SET_06 & 181,95 & 183,81 & 4,29 & 201,13 & 153,67 & 178,71 & 202,48 & 201,00 \\
\hline NOV_06 & $(133,75)$ & $(135,12)$ & $(1,88)$ & $(150,85)$ & $(50,26)$ & $(129,58)$ & $(135,04)$ & $(148,70)$ \\
\hline Total & $4.695,32$ & $4.768,97$ & 197,47 & $5.282,26$ & $7.647,77$ & $5.250,79$ & $4.958,94$ & $5.248,37$ \\
\hline
\end{tabular}

Os resultados financeiros positivos são coerentes com a premissa de assumir uma posição vendida em contrato no mercado futuro para hedgear uma posição comprada no ativo no mercado à vista, quando a série de preços apresenta tendência de queda. Nota-se pelo gráfico 8 , que a série de preços à vista e futuro para o ativo soja apresentaram tal tendência em praticamente todo o período analisado, com exceção de um curto intervalo de alta entre os contratos de março a maio de 2004. Dessa forma, dado que os intervalos de queda dos preços foram maiores que os de alta, contabilizaram-se mais resultados positivos que negativos, por vencimento de contrato.

O gráfico 8 mostra a série de preços à vista e futuro semanais, no dia da operação, encadeada por contrato para a soja. 


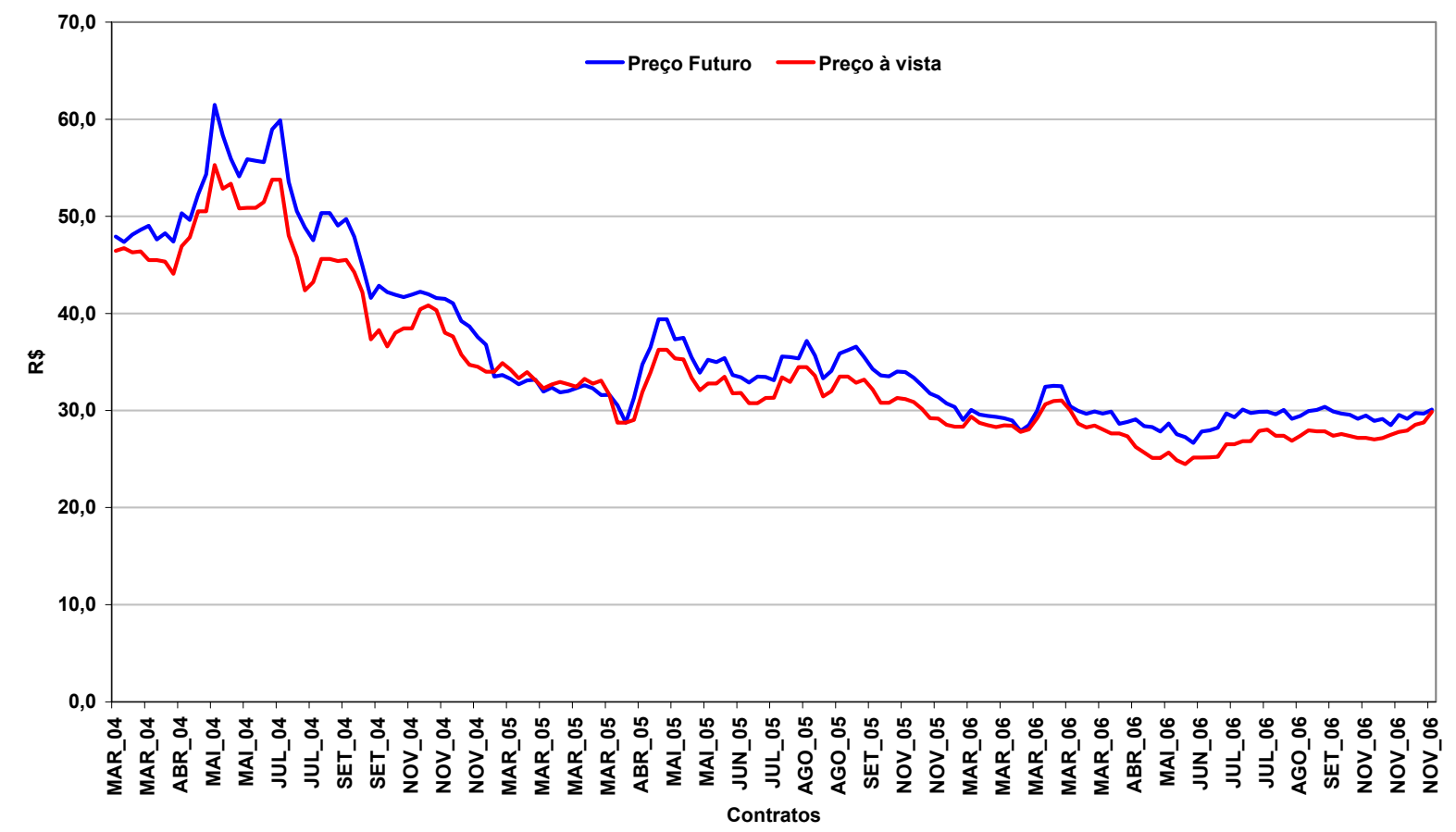

Gráfico 8 - Série de preços à vista e futuro para a soja

Fonte: BM\&F e CEPEA

A análise de variância para a soja aceitou a hipótese nula, apontando que não há diferença estatisticamente significativa entre os resultados financeiros médios obtidos sobre as amostras extraídas das estratégias, como pode ser comprovado pela tabela 14 .

Tabela 14 - Análise de variância de um fator para a soja

\begin{tabular}{|c|c|c|c|c|c|c|}
\hline \multicolumn{7}{|l|}{ ANOVA - Fator único } \\
\hline Fonte da variação & $S Q$ & $g l$ & $\overline{M Q}$ & $F$ & valor- $P$ & F crítico \\
\hline Entre grupos & $1.885 .338,93$ & 7 & $269.334,13$ & 1,84 & 0,08 & 2,04 \\
\hline Dentro dos grupos & $45.663 .154,29$ & 312 & $146.356,26$ & & & \\
\hline Total & $47.548 .493,23$ & 319 & & & & \\
\hline
\end{tabular}

\subsubsection{Dólar Comercial}

O tamanho do contrato utilizado no cômputo do resultado financeiro, tc , foi o tamanho padrão negociado na BM\&F, ou seja, ou seja, US\$100.000. Os resultados financeiros obtidos pelas estratégias para o dólar comercial foram todos positivos, indicando lucro financeiro para o produtor agrícola, como pode ser observado pela tabela 15. 
Tabela 15 - Resultados financeiros por vencimento do dólar comercial (valores em $\mathrm{R} \$$ )

\begin{tabular}{|c|c|c|c|c|c|c|c|c|}
\hline Contratos & estrategia_1 & estrategia_2 & estrategia_3 & estrategia_4 & estrategia_5 & estrategia_6 & estrategia_7 & estrategia_8 \\
\hline FEV_04 & $(404,58)$ & $(408,70)$ & $(7,74)$ & $(498,00)$ & $(72,97)$ & $(339,53)$ & $\begin{array}{l}(716,64) \\
\end{array}$ & $(434,36)$ \\
\hline MAR_04 & 541,54 & 547,07 & 10,39 & 624,32 & 87,53 & 559,75 & 560,35 & 593,19 \\
\hline ABR_04 & $(890,85)$ & $(899,94)$ & $(2,47)$ & $(884,96)$ & $(678,00)$ & $(968,62)$ & $(937,10)$ & $(899,98)$ \\
\hline MAI_04 & $1.832,53$ & $1.851,23$ & 5,18 & $1.850,50$ & $1.707,51$ & $1.886,53$ & $1.972,75$ & $1.857,56$ \\
\hline JUN_04 & $(2.150,84)$ & $(2.172,79)$ & $(2,50)$ & $(2.227,51)$ & $(6.266,81)$ & $(2.039,09)$ & $(2.458,29)$ & $(2.258,15)$ \\
\hline JUL_04 & $6.512,67$ & $6.579,13$ & 39,68 & $6.636,20$ & $3.528,57$ & $6.929,92$ & $6.693,60$ & $6.683,31$ \\
\hline AGO_04 & $8.693,64$ & $8.782,35$ & 39,41 & $8.970,04$ & $5.339,25$ & $9.270,62$ & $8.863,41$ & $8.994,93$ \\
\hline SET_04 & $4.532,42$ & $4.578,67$ & 178,53 & $4.893,20$ & $3.642,48$ & $4.521,12$ & $4.597,86$ & $4.862,85$ \\
\hline OUT_04 & $3.031,93$ & $3.062,87$ & 110,28 & $3.287,70$ & $2.592,13$ & $3.095,69$ & $3.051,73$ & $3.242,39$ \\
\hline NOV_04 & $2.986,85$ & $3.017,33$ & 28,51 & $3.083,42$ & $1.979,84$ & $3.015,04$ & $2.991,74$ & $3.051,65$ \\
\hline DEZ_04 & $7.149,75$ & $7.222,71$ & 88,48 & $7.367,97$ & $6.032,62$ & $7.358,64$ & $7.262,24$ & $7.349,73$ \\
\hline JAN_05 & $7.648,03$ & $7.726,07$ & 13,10 & $8.629,88$ & $3.593,28$ & $6.961,25$ & $7.778,91$ & $7.871,34$ \\
\hline FEV_05 & 996,97 & $1.007,15$ & 105,31 & $1.089,28$ & $(172,11)$ & $1.008,19$ & $1.045,00$ & $1.077,96$ \\
\hline MAR_05 & 234,20 & 236,59 & 21,76 & 269,75 & $(100,95)$ & 243,04 & 246,97 & 258,14 \\
\hline ABR_05 & $(1.828,08)$ & $(1.846,73)$ & $(40,40)$ & $(1.999,10)$ & $(2.268,53)$ & $(2.122,10)$ & $(1.860,98)$ & $(1.952,75)$ \\
\hline MAI_05 & $12.344,37$ & $12.470,33$ & 100,03 & $12.567,35$ & $18.644,15$ & $12.615,34$ & $13.002,76$ & $12.604,46$ \\
\hline JUN_05 & $9.332,58$ & $9.427,81$ & 175,96 & $9.623,55$ & $14.335,31$ & $9.345,02$ & $9.384,08$ & $9.584,56$ \\
\hline JUL_05 & $2.609,02$ & $2.635,65$ & $(107,03)$ & $2.945,41$ & $1.886,65$ & $2.284,55$ & $2.744,56$ & $2.715,28$ \\
\hline AGO_05 & $1.131,65$ & $1.143,20$ & 6,06 & $1.224,94$ & $1.436,45$ & $1.055,27$ & $1.247,55$ & $1.188,27$ \\
\hline SET_05 & 183,74 & 185,62 & 6,11 & 177,36 & 15,54 & 193,60 & 189,69 & 165,47 \\
\hline OUT_05 & $11.582,74$ & $11.700,93$ & 163,09 & $11.804,80$ & $8.528,11$ & $11.560,12$ & $12.617,80$ & $11.771,38$ \\
\hline NOV_05 & 6,45 & 6,51 & $(0,12)$ & 5,18 & 27,03 & 10,54 & 9,80 & 7,37 \\
\hline DEZ_05 & $3.555,85$ & $3.592,13$ & 70,95 & $3.662,37$ & $3.126,61$ & $3.491,92$ & $3.625,02$ & $3.666,32$ \\
\hline JAN_06 & $(7.150,65)$ & $(7.223,62)$ & $(76,82)$ & $(7.637,83)$ & $(4.810,78)$ & $(6.351,95)$ & $(7.311,85)$ & $(7.535,98)$ \\
\hline FEV_06 & 812,88 & 821,17 & 103,57 & 942,12 & $(73,80)$ & 751,82 & 844,58 & 906,71 \\
\hline MAR_06 & 792,89 & 800,98 & 89,08 & $1.018,66$ & $(62,70)$ & 782,84 & 778,38 & 979,94 \\
\hline ABR_06 & $(2.528,18)$ & $(2.553,97)$ & $(52,52)$ & $(2.578,34)$ & $(2.648,18)$ & $(2.546,53)$ & $(2.617,68)$ & $(2.565,72)$ \\
\hline MAI_06 & $2.712,53$ & $2.740,21$ & 46,28 & $2.768,52$ & $2.981,71$ & $2.729,92$ & $2.773,35$ & $2.767,56$ \\
\hline JUN_06 & $(12.149,93)$ & $(12.273,90)$ & $(337,58)$ & $(12.443,83)$ & $(13.703,05)$ & $(12.190,81)$ & $(12.290,05)$ & $(12.441,06)$ \\
\hline JUL_06 & $3.028,53$ & $3.059,44$ & 276,98 & $3.419,07$ & 115,94 & $2.571,76$ & $3.131,77$ & $3.382,95$ \\
\hline AGO_06 & 441,61 & 446,12 & 41,04 & 492,68 & 18,42 & 444,23 & 437,36 & 489,94 \\
\hline SET_06 & $1.021,73$ & $1.032,16$ & 102,88 & $1.100,28$ & 84,58 & 980,07 & $1.054,44$ & $1.094,55$ \\
\hline OUT_06 & 46,17 & 46,64 & 2,21 & 25,45 & 94,23 & 33,64 & 54,78 & 22,37 \\
\hline NOV_06 & 208,67 & 210,80 & 12,30 & 226,77 & $(20,51)$ & 196,74 & 215,56 & 225,12 \\
\hline DEZ_06 & $(864,63)$ & $(873,45)$ & $(2,47)$ & $(872,06)$ & $(1.017,53)$ & $(843,23)$ & $(939,53)$ & $(869,13)$ \\
\hline Total & $66.004,23$ & $66.677,74$ & $1.207,53$ & $69.565,16$ & $47.901,99$ & $66.495,32$ & $68.043,91$ & $68.458,19$ \\
\hline
\end{tabular}

Os resultados financeiros positivos são coerentes com a premissa de assumir uma posição vendida em contrato no mercado futuro para hedgear uma posição comprada no ativo no mercado à vista, quando a série de preços apresenta tendência de queda. Nota-se pelo gráfico 9, que a série de preços à vista e futuro para o ativo dólar comercial apresentaram tal tendência em praticamente todo o período analisado, com exceção de um curto intervalo de alta entre os contratos de fevereiro a julho de 2004. Dessa forma, dado que os intervalos de queda dos preços foram maiores que os períodos os intervalos de alta dos mesmos, contabilizaram-se mais resultados positivos que negativos, por vencimento de contrato.

O gráfico 9 mostra a série de preços à vista e futuro semanais, no dia da operação, encadeada por contrato para o dólar comercial. 


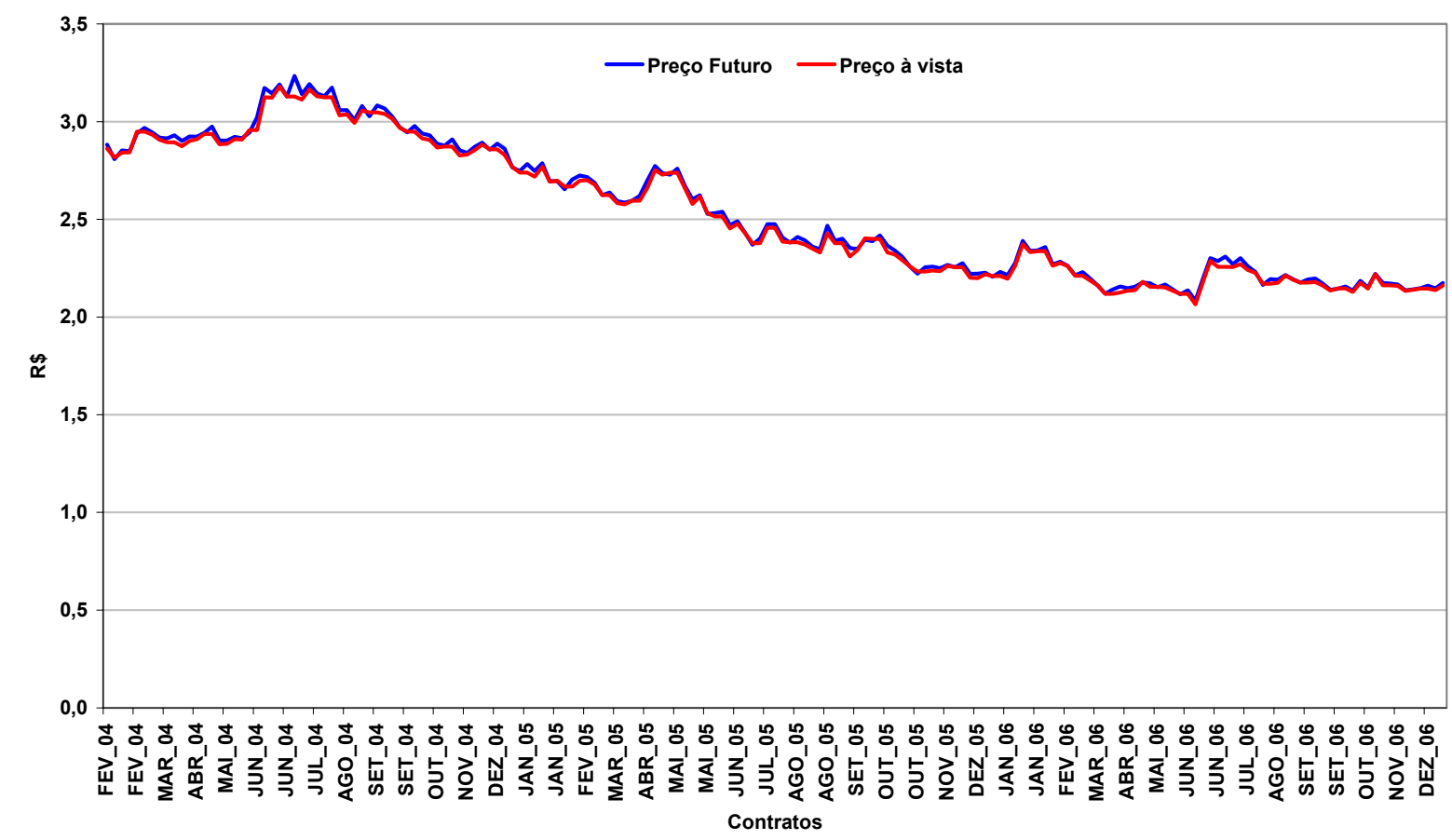

Gráfico 9 - Série de preços à vista e futuro para o dólar comercial encadeados por contrato Fonte: BM\&F e Banco Central do Brasil

A análise de variância para o dólar comercial aceitou a hipótese nula, apontando que não há diferença estatisticamente significativa entre os resultados financeiros médios obtidos sobre as amostras extraídas das estratégias, como pode ser comprovado pela tabela 16 .

Tabela 16 - Análise de variância de um fator para o dólar comercial

\begin{tabular}{|c|c|c|c|c|c|c|}
\hline \multicolumn{7}{|c|}{ ANOVA - Fator Unico } \\
\hline Fonte da variação & $S Q$ & $g l$ & $M Q$ & $F$ & valor- $P$ & F crítico \\
\hline Entre grupos & $35.443 .381,92$ & $\frac{7}{7}$ & $5.063 .340,27$ & 1,27 & 0,26 & 2,04 \\
\hline Dentro dos grupos & $1.239 .395 .595,47$ & 312 & $3.972 .421,78$ & & & \\
\hline Total & $1.274 .838 .977,39$ & 319 & & & & \\
\hline
\end{tabular}

\subsubsection{Ibovespa}

O tamanho do contrato utilizado no cômputo do resultado financeiro, tc, foi o tamanho padrão negociado na BM\&F, ou seja, Ibovespa em pontos multiplicado pelo valor de um real por ponto. Os resultados financeiros obtidos pelas estratégias para o Ibovespa foram todos negativos, com exceção para a estratégia 5, indicando prejuízo financeiro para o produtor agrícola, na maioria das estratégias analisadas, como pode ser observado pela tabela 17. 
Tabela 17 - Resultados financeiros por vencimento do lbovespa (valores em R\$)

\begin{tabular}{|c|c|c|c|c|c|c|c|c|}
\hline Contratos & estrategia_1 & estrategia_2 & estrategia_3 & estrategia_4 & estrategia_5 & estrategia_6 & estrategia_7 & estrategia_8 \\
\hline FEV_04 & $1.591,11$ & $1.610,02$ & 81,37 & $1.807,85$ & $2.456,75$ & $1.617,50$ & $1.572,03$ & $1.812,11$ \\
\hline ABR_04 & $(245,64)$ & $(248,29)$ & $(15,46)$ & $(254,20)$ & $(248,76)$ & $(241,55)$ & $(253,96)$ & $(250,53)$ \\
\hline JUN_04 & $3.085,21$ & $3.116,70$ & 146,19 & $3.183,49$ & $3.676,77$ & $3.073,25$ & $3.128,94$ & $3.183,94$ \\
\hline AGO_04 & $(1.881,30)$ & $(1.900,49)$ & $(85,35)$ & $(1.948,08)$ & $(2.552,59)$ & $(1.870,20)$ & $(1.875,37)$ & $(1.940,48)$ \\
\hline OUT_04 & $(978,27)$ & $(988,26)$ & $(40,83)$ & $(1.090,19)$ & 144,11 & $(965,41)$ & $(1.009,23)$ & $(1.091,47)$ \\
\hline DEZ_04 & $(523,71)$ & $(529,05)$ & $(10,47)$ & $(538,06)$ & $(549,13)$ & $(532,08)$ & $(527,52)$ & $(539,78)$ \\
\hline FEV_05 & 591,01 & 597,04 & $(7,55)$ & 656,43 & $3.503,65$ & 629,55 & 560,03 & 667,20 \\
\hline ABR_05 & 910,78 & 913,89 & 25,32 & 920,87 & $1.123,84$ & 916,88 & 948,12 & 927,17 \\
\hline JUN_05 & $1.286,13$ & $1.299,25$ & 34,68 & $1.331,90$ & $1.333,71$ & $1.291,57$ & $1.362,04$ & $1.330,71$ \\
\hline AGO_05 & $(1.050,16)$ & $(1.060,87)$ & $(62,01)$ & $(1.169,30)$ & 282,59 & $(1.026,15)$ & $(1.078,83)$ & $(1.166,67)$ \\
\hline OUT_05 & $(2.241,61)$ & $(2.294,50)$ & $(26,91)$ & $(2.285,88)$ & $(2.262,51)$ & $(2.327,97)$ & $(2.282,93)$ & $(2.289,80)$ \\
\hline DEZ_05 & $(1.926,80)$ & $(1.946,46)$ & $(62,12)$ & $(1.975,55)$ & $(2.368,54)$ & $(1.974,72)$ & $(1.957,85)$ & $(1.983,03)$ \\
\hline FEV_06 & $(2.196,45)$ & $(2.218,86)$ & $(60,76)$ & $(2.372,21)$ & $(2.628,20)$ & $(2.236,32)$ & $(2.240,82)$ & $(2.370,34)$ \\
\hline ABR_06 & $(1.461,03)$ & $(1.475,93)$ & $(29,98)$ & $(1.481,84)$ & $(2.397,29)$ & $(1.471,55)$ & $(1.484,18)$ & $(1.487,64)$ \\
\hline JUN_06 & $4.756,35$ & $4.804,89$ & 151,70 & $5.011,40$ & $5.637,38$ & $4.760,13$ & $4.832,99$ & $5.012,43$ \\
\hline AGO_06 & $(1.594,63)$ & $(1.632,37)$ & $(116,98)$ & $(1.629,21)$ & $(1.010,34)$ & $(1.770,89)$ & $(1.636,19)$ & $(1.618,45)$ \\
\hline OUT_06 & $(1.570,68)$ & $(1.589,04)$ & $(32,54)$ & $(1.634,68)$ & $(315,18)$ & $(1.563,68)$ & $(1.600,94)$ & $(1.624,30)$ \\
\hline DEZ 06 & $(2.647,91)$ & $(2.674,93)$ & $(43,50)$ & $(2.686,37)$ & $(3.065,89)$ & $(2.697,22)$ & $(2.649,11)$ & $(2.701,34)$ \\
\hline Total & $(6.097,59)$ & $(6.217,26)$ & $(155,22)$ & $(6.153,65)$ & 760,37 & $(6.388,85)$ & $(6.192,79)$ & $(6.130,28)$ \\
\hline
\end{tabular}

Os resultados financeiros negativos são coerentes com a premissa de assumir uma posição vendida em contrato no mercado futuro para hedgear uma posição comprada no ativo no mercado à vista, quando a série de preços apresenta tendência de alta. Nota-se pelo gráfico 10, que a série de preços à vista e futuro para o ativo Ibovespa, apresentaram tal tendência em praticamente todo o período analisado, com exceção de curtos intervalos de queda entre os contratos de fevereiro a junho de 2004, entre os contratos de abril a agosto de 2005 e no contrato de junho de 2006. Dessa forma, dado que os intervalos de alta do preço futuro foram maiores que os períodos os intervalos de queda do mesmo, contabilizaram-se mais resultados negativos que positivos, por vencimento de contrato, para todas as estratégias com exceção da estratégia 5. Nessa estratégia, como pode ser observado pela tabela 17, houveram alguns vencimentos que apresentaram resultados positivos mais significativos e que foram decisivos na determinação do resultado financeiro final.

O gráfico 10 mostra a série de preços à vista e futuro semanais, no dia da operação, encadeada por contrato para o lbovespa. 


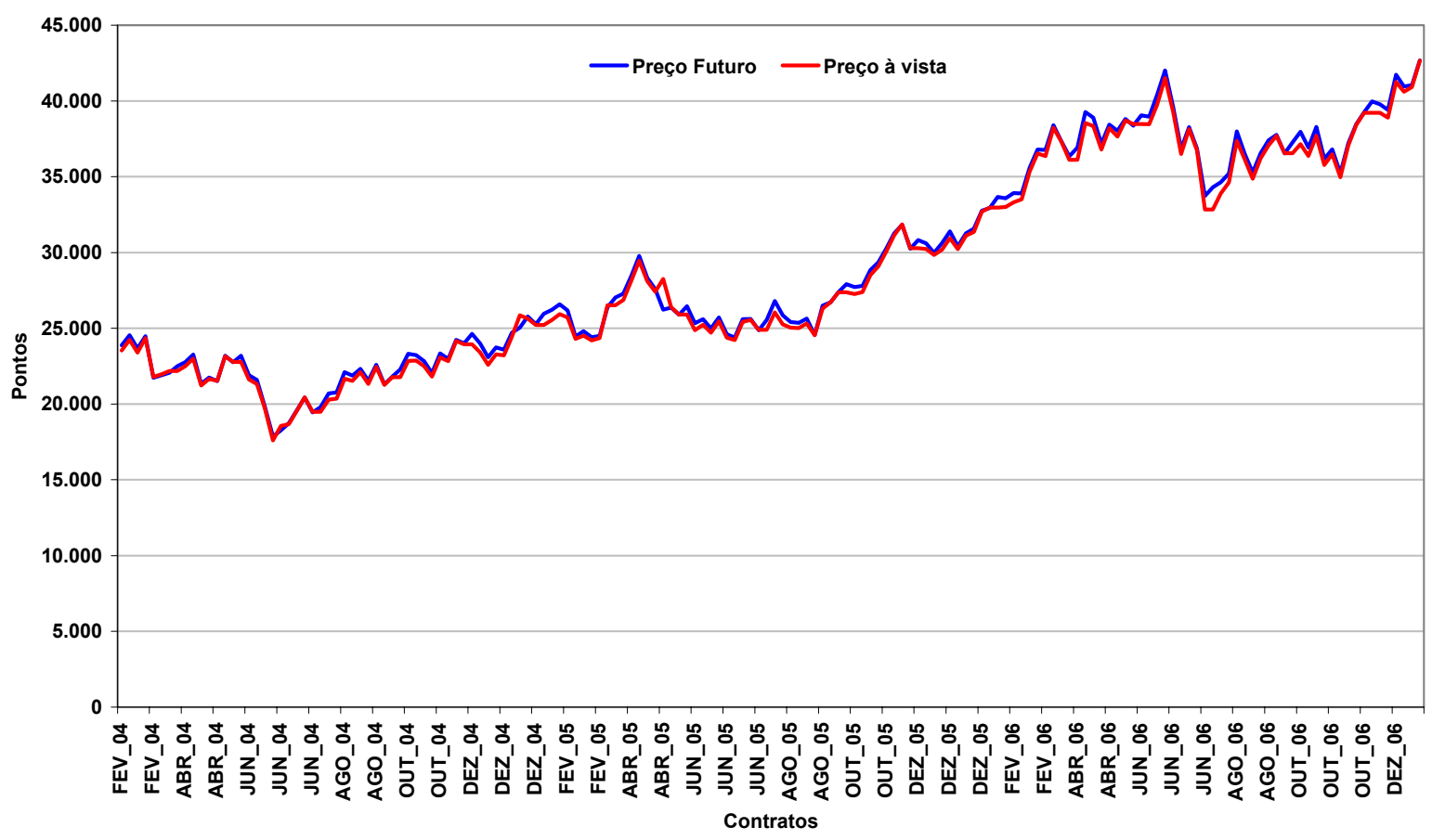

Gráfico 10 - Série de preços à vista e futuro para o Ibovespa encadeados por contrato Fonte: BM\&F e CEPEA

A análise de variância para o Ibovespa aceitou a hipótese nula, apontando que não há diferença estatisticamente significativa entre os resultados financeiros médios obtidos sobre as amostras extraídas das estratégias, como pode ser comprovado pela tabela 18 .

Tabela 18 - Análise de variância de um fator para o Ibovespa

\begin{tabular}{lccccc}
\hline ANOVA - Fator único & & & & \\
\hline Fonte da variação & $S Q$ & $g l$ & $M Q$ & valor-P \\
\hline Entre grupos & $2.446 .193,01$ & 7 & $349.456,14$ & 0,46 & 0,87 \\
Dentro dos grupos & $239.061 .078,17$ & 312 & $766.221,40$ & 2,04 \\
Total & $241.507 .271,18$ & 319 & & & \\
\hline
\end{tabular}

Pelos resultados dos testes estatísticos, apresentados das análises de variância sobre os resultados financeiros médios obtidos das amostras extraídas aleatoriamente, conclui-se que não há diferenças estatisticamente significativa entre as estratégias, quando analisadas sob a ótica de um mesmo ativo, para todos os ativos utilizados para análise nesse trabalho. 


\subsection{Análise de Variância por Estratégia}

O propósito dessa análise é identificar se há diferenças estatisticamente significativa entre os resultados financeiros médios obtidos sobre as amostras de tamanho 40, que sejam justificados pelos ativos estudados, quando analisados sob a ótica de uma mesma estratégia. As características e especificações dos contratos futuros para cada ativo são as mesmas descritas no item 6.1.

\subsubsection{Estratégia 1}

A análise de variância para a estratégia 1 aceitou a hipótese nula, apontando que não há diferença estatisticamente significativa entre os resultados financeiros médios obtidos sobre as amostras extraídas dos ativos, como pode ser comprovado pela tabela 19.

Tabela 19 - Análise de variância para a estratégia 1

\begin{tabular}{lcccccc}
\hline ANOVA - Fator único & & & & & \\
\hline Fonte da variação & $S Q$ & gl & $M Q$ & $F$ & valor-P & F crítico \\
\hline Entre grupos & $4.503 .896,63$ & 5 & $900.779,33$ & 0,68 & 0,64 & 2,25 \\
Dentro dos grupos & $309.218 .924,69$ & 234 & $1.321 .448,40$ & & & \\
& & & & & & \\
Total & $313.722 .821,33$ & 239 & & & \\
\hline
\end{tabular}

\subsubsection{Estratégia 2}

A análise de variância para a estratégia 2 aceitou a hipótese nula, apontando que não há diferença estatisticamente significativa entre os resultados financeiros médios obtidos sobre as amostras extraídas dos ativos, como pode ser comprovado pela tabela 20 .

Tabela 20 - Análise de variância para a estratégia 2

\begin{tabular}{lcccccc}
\hline ANOVA - Fator único & \multicolumn{7}{c}{ valor-P } & F crítico \\
\hline Fonte da variação & $S Q$ & 5 & $M Q$ & $F$ & 2,25 \\
\hline Entre grupos & $4.614 .413,38$ & 5 & $922.882,68$ & 0,55 & & \\
Dentro dos grupos & $394.215 .502,27$ & 234 & $1.684 .681,63$ & & & \\
& & & & & & \\
Total & $398.829 .915,65$ & 239 & & & & \\
\hline
\end{tabular}




\subsubsection{Estratégia 3}

A análise de variância para a estratégia 3 aceitou a hipótese nula, apontando que não há diferença estatisticamente significativa entre os resultados financeiros médios obtidos sobre as amostras extraídas dos ativos, como pode ser comprovado pela tabela 21

Tabela 21 - Análise de variância para a estratégia 3

\begin{tabular}{|c|c|c|c|c|c|c|}
\hline \\
\hline \multicolumn{7}{|l|}{$\frac{\text { ANOVA - Fator único }}{\text { Fonte da variacão }}$} \\
\hline Entre grupos & $5.141,94$ & 5 & $1.028,39$ & 0,59 & 0,70 & 2,25 \\
\hline Dentro dos grupos & $404.857,66$ & 234 & $1.730,16$ & & & \\
\hline Total & $409.999,60$ & 239 & & & & \\
\hline
\end{tabular}

\subsubsection{Estratégia 4}

A análise de variância para a estratégia 4 aceitou a hipótese nula, apontando que não há diferença estatisticamente significativa entre os resultados financeiros médios obtidos sobre as amostras extraídas dos ativos, como pode ser comprovado pela tabela 22 .

Tabela 22 - Análise de variância para a estratégia 4

\begin{tabular}{lccccc}
\hline ANOVA - Fator único & & & & \\
\hline Fonte da variação & $S Q$ & gl & MQ & $F$ & valor-P \\
\hline Entre grupos & $11.858 .533,09$ & 5 & $2.371 .706,62$ & 1,70 & 0,14 \\
Dentro dos grupos & $327.340 .785,12$ & 234 & $1.398 .892,24$ & 2,25 \\
Total & $339.199 .318,20$ & 239 & & & \\
\hline
\end{tabular}

\subsubsection{Estratégia 5}

A análise de variância para a estratégia 5 aceitou a hipótese nula, apontando que não há diferença estatisticamente significativa entre os resultados financeiros médios obtidos sobre as amostras extraídas dos ativos, como pode ser comprovado pela tabela 23 . 
Tabela 23 - Análise de variância para a estratégia 5

\begin{tabular}{lccccc}
\hline ANOVA - Fator único & & & & \\
\hline Fonte da variação & $S Q$ & $g l$ & $M Q$ & $F$ & valor-P \\
\hline Entre grupos & $5.847 .986,58$ & 5 & $1.169 .597,32$ & 0,75 & 0,59 \\
Dentro dos grupos & $363.840 .151,77$ & 234 & $1.554 .872,44$ & & 2,25 \\
& & & & & \\
Total & $369.688 .138,35$ & 239 & & & \\
\hline
\end{tabular}

\subsubsection{Estratégia 6}

A análise de variância para a estratégia 6 aceitou a hipótese nula, apontando que não há diferença estatisticamente significativa entre os resultados financeiros médios obtidos sobre as amostras extraídas dos ativos, como pode ser comprovado pela tabela 24 .

Tabela 24 - Análise de variância para a estratégia 6

\begin{tabular}{lccccc}
\hline ANOVA - Fator único & & & & & \\
\hline Fonte da variação & $S Q$ & gl & MQ & $F$ & valor-P \\
\hline Entre grupos & $2.563 .133,99$ & 5 & $512.626,80$ & 0,37 & 0,87 \\
Dentro dos grupos & $327.186 .714,47$ & 234 & $1.398 .233,82$ & & 2,25 \\
& & & & & \\
Total & $329.749 .848,45$ & 239 & & & \\
\hline
\end{tabular}

\subsubsection{Estratégia 7}

A análise de variância para a estratégia 7 aceitou a hipótese nula, apontando que não há diferença estatisticamente significativa entre os resultados financeiros médios obtidos sobre as amostras extraídas dos ativos, como pode ser comprovado pela tabela 25 .

Tabela 25 - Análise de variância para a estratégia 7

\begin{tabular}{lccccc}
\hline ANOVA - Fator único & & & & & \\
\hline Fonte da variação & $S Q$ & $g l$ & $M Q$ & $F$ & valor-P \\
\hline Entre grupos & $1.954 .531,48$ & 5 & $390.906,30$ & 0,18 & 0,97 \\
Dentro dos grupos & $498.258 .222,58$ & 234 & $2.129 .308,64$ & & \\
& & & & & \\
Total & $500.212 .754,06$ & 239 & & & \\
\hline
\end{tabular}

\subsubsection{Estratégia 8}


A análise de variância para a estratégia 8 aceitou a hipótese nula, apontando que não há diferença estatisticamente significativa entre os resultados financeiros médios obtidos sobre as amostras extraídas dos ativos, como pode ser comprovado pela tabela 26 .

Tabela 26 - Análise de variância para a estratégia 8

\begin{tabular}{lccccc}
\hline ANOVA - Fator único & \multicolumn{5}{c}{} \\
\hline Fonte da variação & $S Q$ & $g l$ & $M Q$ & $F$ & valor-P \\
\hline Entre grupos & $7.191 .543,94$ & 5 & $1.438 .308,79$ & 1,79 & 0,11 \\
Dentro dos grupos & $187.665 .867,07$ & 234 & $801.990,88$ & 2,25 \\
& & & & & \\
Total & $194.857 .411,01$ & 239 & & & \\
\hline
\end{tabular}

Pelos resultados dos testes estatísticos das análises de variância sobre os resultados financeiros médios obtidos das amostras extraídas aleatoriamente, conclui-se que não há diferenças estatisticamente significativa entre os ativos, quando analisados sob a ótica de uma mesma estratégia, para todos os ativos utilizados para análise nesse trabalho.

\subsection{Análise da Eficácia das Estratégias}

Analisou-se o comparativo entre a medida de eficácia das estratégias com o propósito de determinar qual delas foi mais eficaz para os ativos analisados. A comparação foi baseada sobre a premissa de redução de risco, mensurando o quanto se ganhou em redução de risco por utilizar determinada estratégia sobre o portfólio hedgeado, composto por dois ativos, um no mercado à vista e outro no mercado futuro, quando comparado ao risco de manter apenas da posição no mercado à vista, denominada posição não-hedgeada. Tal medida é determinada pela equação 3.21 .

Os resultados dessas medidas são primeiramente apresentados em gráficos em linha, os quais mostram a evolução e comportamento dessas medidas dentro do período do estudo, para cada ativo. Em seguida, são apresentados também gráficos box-plot como instrumento de análise descritiva do conjunto de resultados das medidas de eficácia, por estratégia para cada ativo. A decisão sobre qual estratégia 
foi mais eficaz para o ativo, foi determinada pela estratégia que apresentou maior mediana.

\subsubsection{Açúcar Cristal}

Analisando a medida de eficácia para o açúcar cristal, nota-se pelo gráfico 11 que não há como afirmar haver uma estratégia superior as demais por unanimidade. Observa-se, no entanto, que as estratégias 1, 2, 4, 6, 7 e 8, têm um comportamento muito semelhante, diferenciado-se das demais, 3 e 5 . Dentre as estratégias que têm influência do parâmetro de aversão ao risco, 4 e 5, quando analisadas sob o ponto de vista do parâmetro 1.000 considerado nesse trabalho, nota-se que apresentaram um comportamento bastante divergente. A estratégia 5, apresentou maior variabilidade, mostrando-se ora eficaz, ora não eficaz. Já a estratégia 4, mostrou-se praticamente idêntica ao comportamento das estratégias que não consideram o parâmetro de aversão ao risco em seu cômputo. Por fim, a estratégia 3, apresentou um comportamento plano e próximo a zero, ao longo do período analisado.

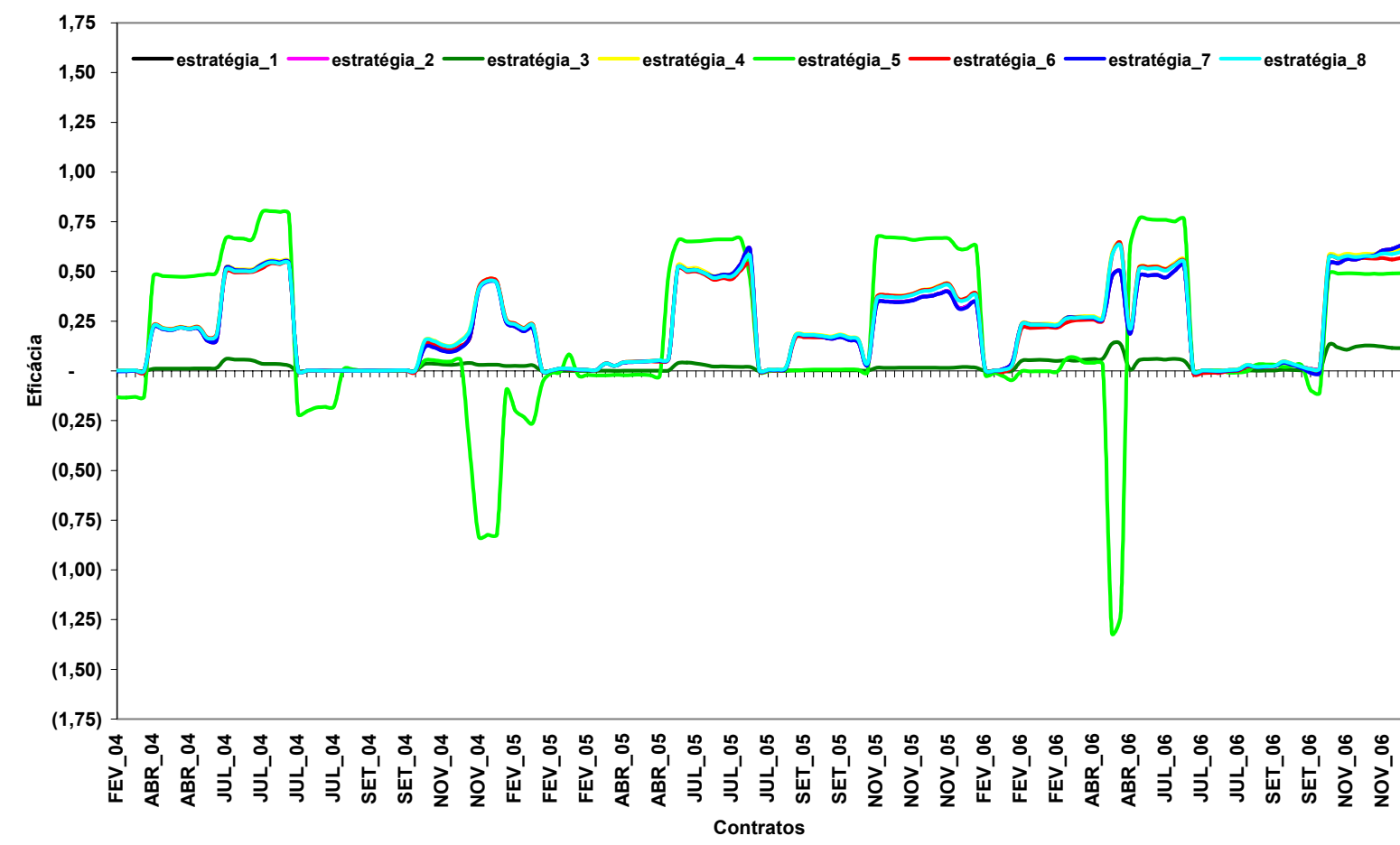

Gráfico 11 - Evolução das medidas de eficácia por estratégia para o açúcar cristal

Com objetivo comparar estatisticamente a medida de eficácia das estratégias para o açúcar cristal, realizou-se uma análise descritiva dos dados apresentada na figura 3. 
Estratégia 1

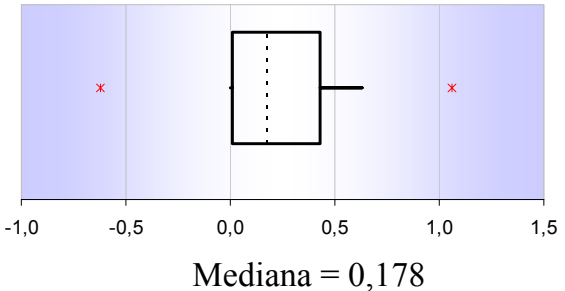

Estratégia 3

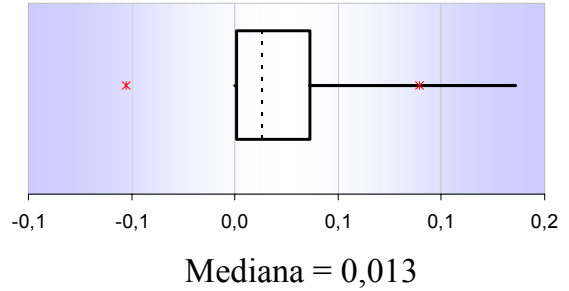

Estratégia 5

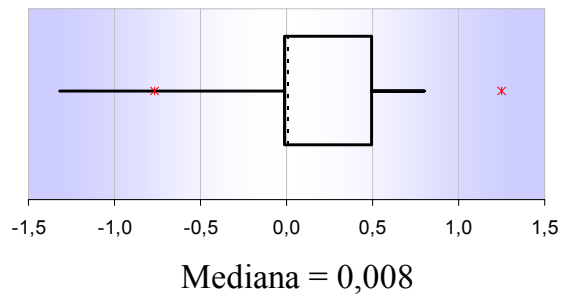

Estratégia 7

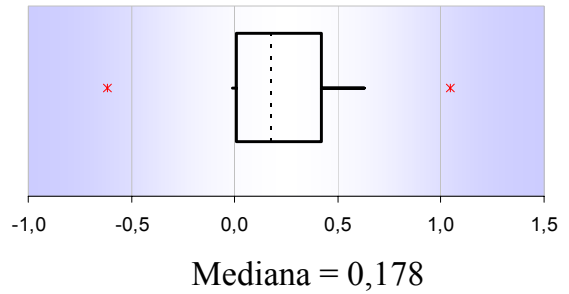

Estratégia 2

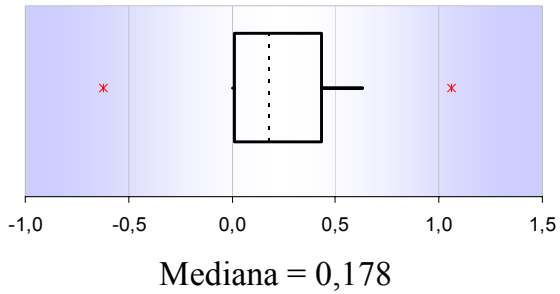

Estratégia 4

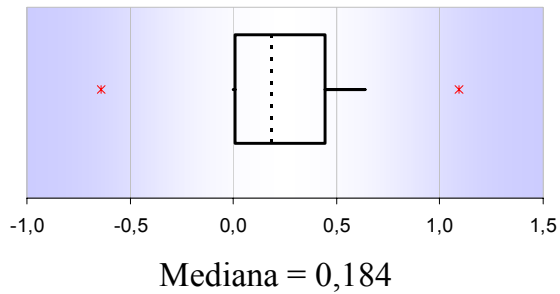

Estratégia 6

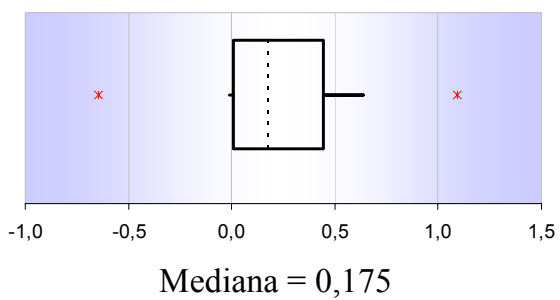

Estratégia 8

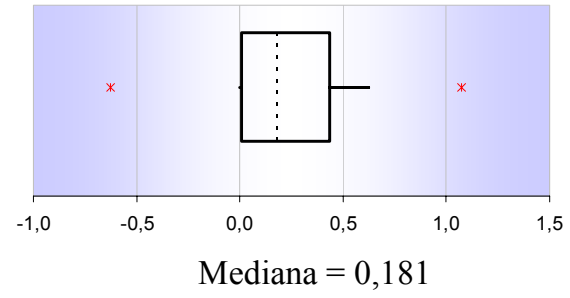

Figura 3 - Gráficos box-plot e medianas das medidas de eficácia para o ativo açúcar cristal

Observa-se pela figura 3 , que a estratégia 4 apresentou a maior mediana quando comparada com as demais. Dessa forma, pode-se afirmar que ela é a mais eficaz para o açúcar cristal. 


\subsection{2. Álcool Anidro}

Analisando a medida de eficácia para o álcool anidro, nota-se pelo gráfico 12 que não há como afirmar haver uma estratégia superior as demais por unanimidade. Observa-se, no entanto, que as estratégias 1, 2, 4, 6, 7 e 8, têm um comportamento muito semelhante, apesar de a estratégia 7 ter diferenciado em magnitude delas nos primeiros contratos de 2004, diferente das demais, 3 e 5. Dentre as estratégias que têm influência do parâmetro de aversão ao risco, 4 e 5, quando analisadas sob o ponto de vista do parâmetro 1.000 considerado nesse trabalho, nota-se que apresentaram um comportamento bastante divergente. A estratégia 5, apresentou maior variabilidade, mostrando-se ora eficaz, ora não eficaz. Já a estratégia 4, mostrou-se praticamente idêntica ao comportamento das estratégias que não consideram o parâmetro de aversão ao risco em seu cômputo. Por fim, a estratégia 3, apresentou um comportamento plano e próximo a zero, ao longo do período analisado.

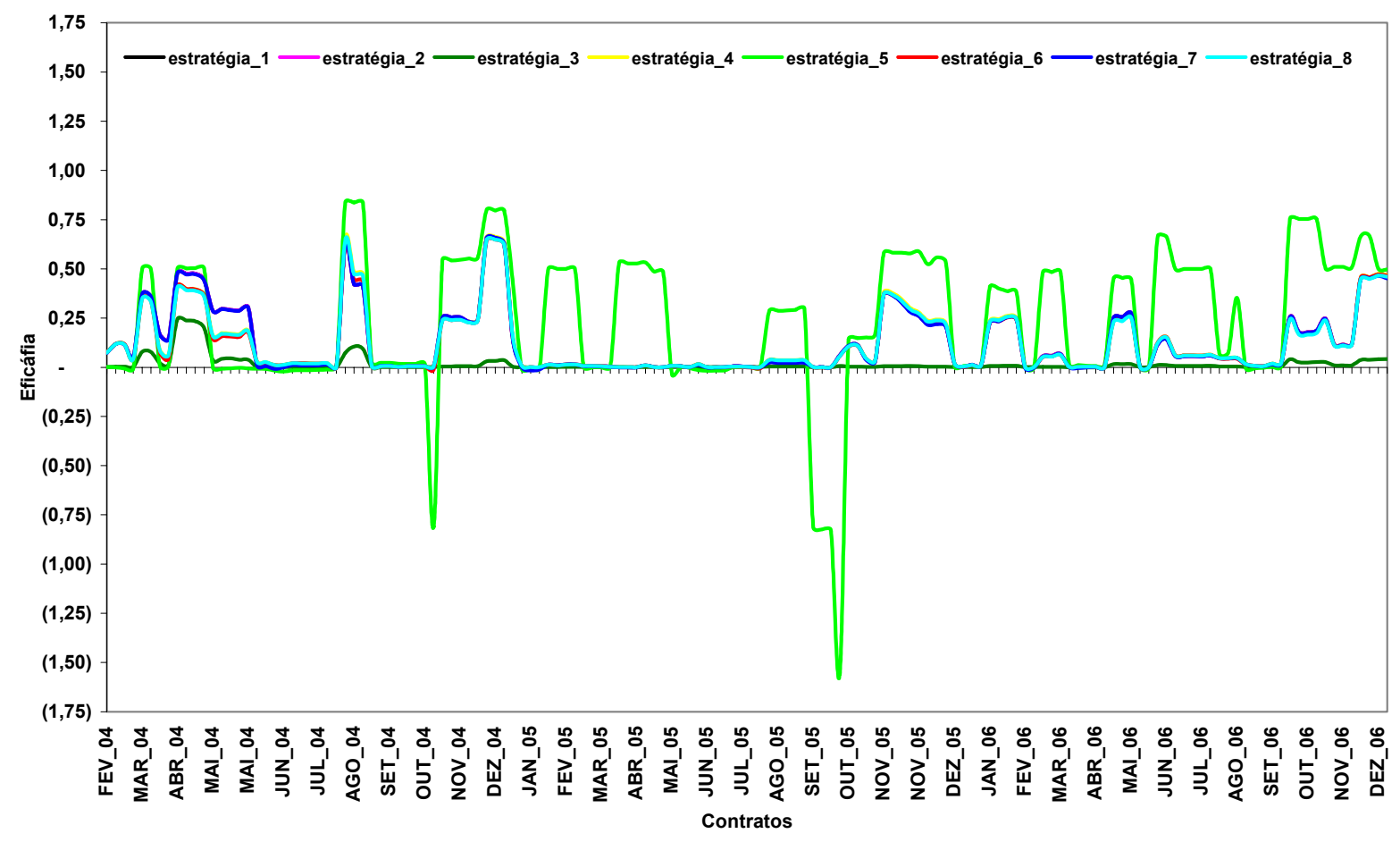

Gráfico 12 - Evolução das medidas de eficácia por estratégia para o álcool anidro 
Com objetivo comparar estatisticamente a medida de eficácia das estratégias para o álcool anidro, realizou-se uma análise descritiva dos dados apresentada na figura 4.

Estratégia 1

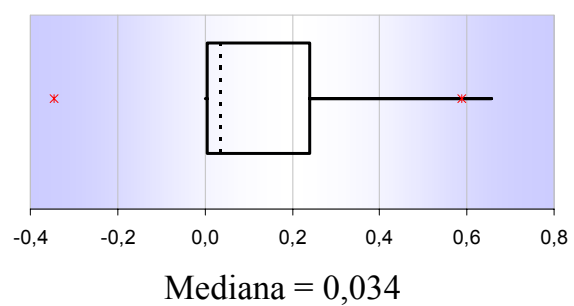

Estratégia 3

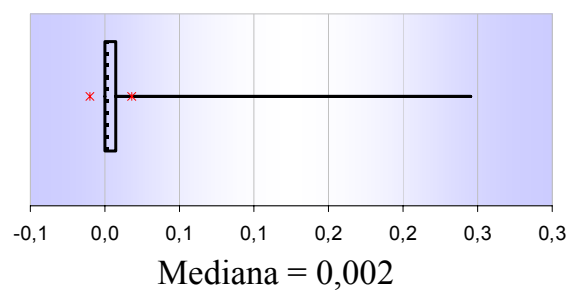

Estratégia 5

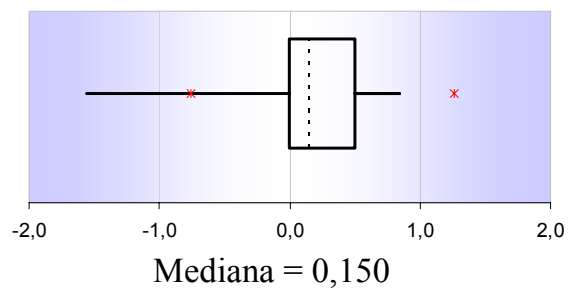

Estratégia 7

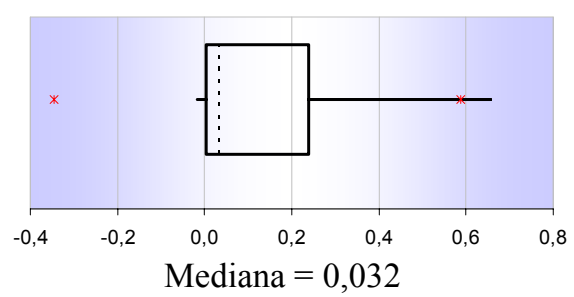

Estratégia 2

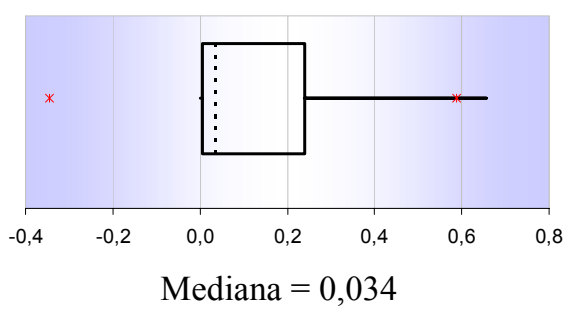

Estratégia 4

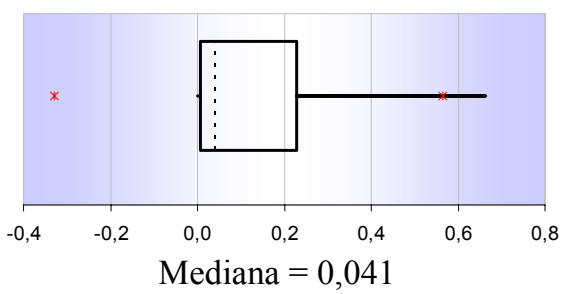

Estratégia 6

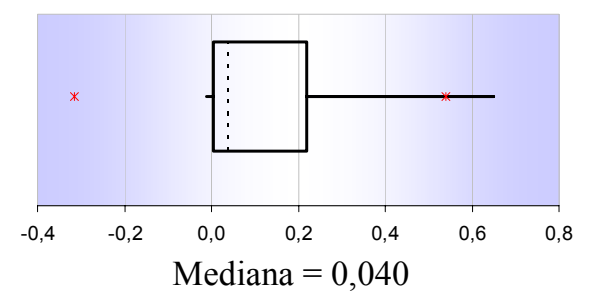

Estratégia 8

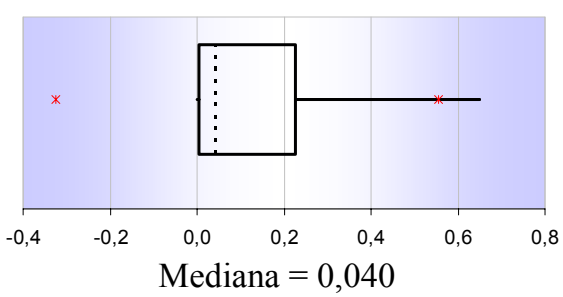

Figura 4 - Gráficos box-plot e medianas das medidas de eficácia para o álcool anidro

Observa-se pela figura 4, que a estratégia 5 apresentou a maior mediana quando comparada com as demais. Dessa forma, pode-se afirmar que ela é a mais eficaz para o álcool anidro. 


\subsubsection{Café Arábica}

Analisando a medida de eficácia para o café arábica, nota-se pelo gráfico 13 que não há como afirmar haver uma estratégia superior as demais por unanimidade. Observa-se, no entanto, que as estratégias 1, 2, 4, 6, 7 e 8, têm um comportamento muito semelhante, diferente das demais, 3 e 5 . Dentre as estratégias que têm influência do parâmetro de aversão ao risco, 4 e 5, quando analisadas sob o ponto de vista do parâmetro 1.000 considerado nesse trabalho, nota-se que apresentaram um comportamento bastante divergente. A estratégia 5, apresentou maior variabilidade, e apesar de eficaz na maior parte do período estudado, mostrou-se não eficaz, no período que compreende o contrato de dezembro de 2005. Já a estratégia 4 , mostrou-se praticamente idêntica ao comportamento das estratégias que não consideram o parâmetro de aversão ao risco em seu cômputo. Por fim, a estratégia 3 , apresentou um comportamento plano e próximo a zero, ao longo do período analisado.

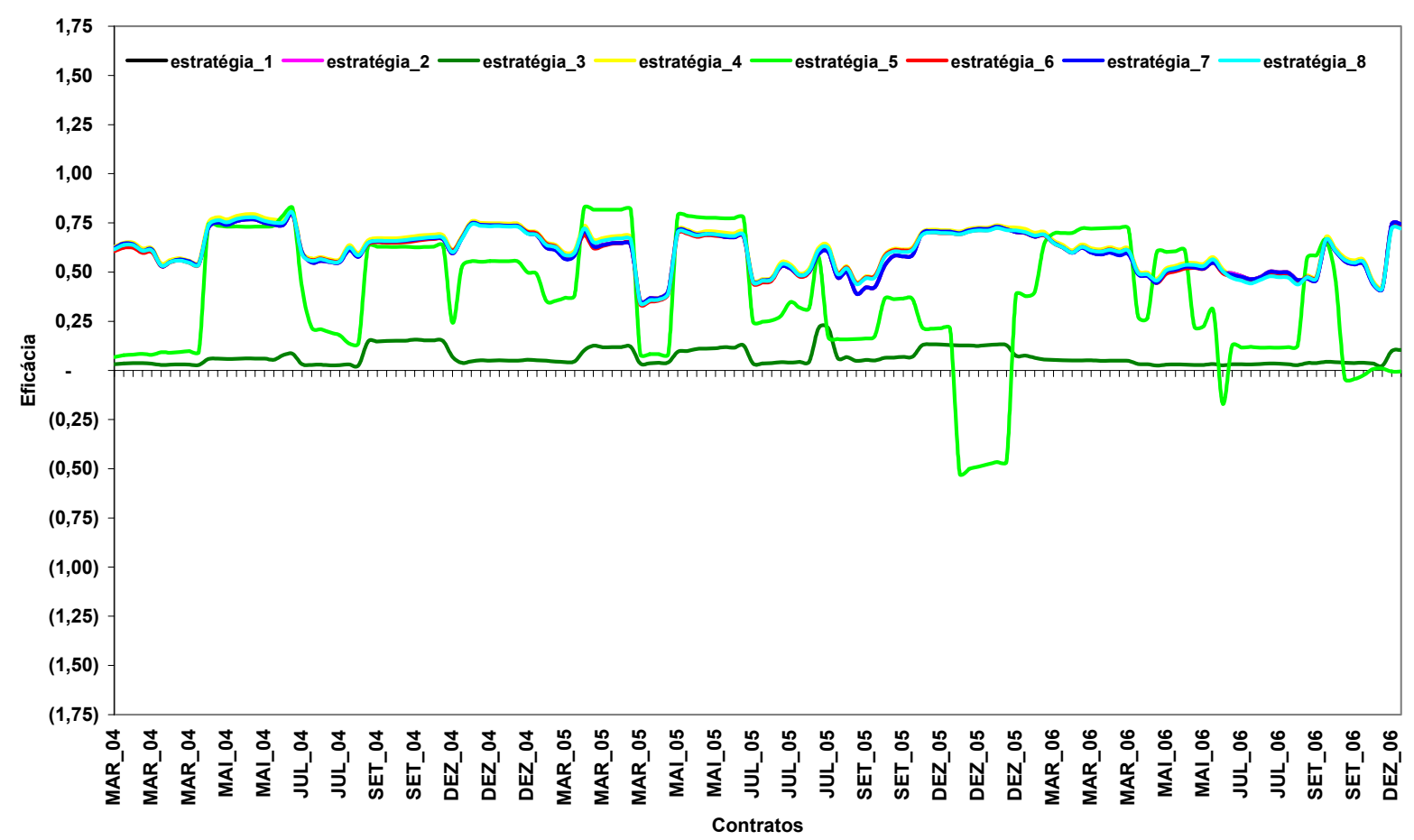

Gráfico 13 - Evolução das medidas de eficácia por estratégia para o café arábica 
Com objetivo comparar estatisticamente a medida de eficácia das estratégias para o café arábica, realizou-se uma análise descritiva dos dados apresentada na figura 5 .

Estratégia 1

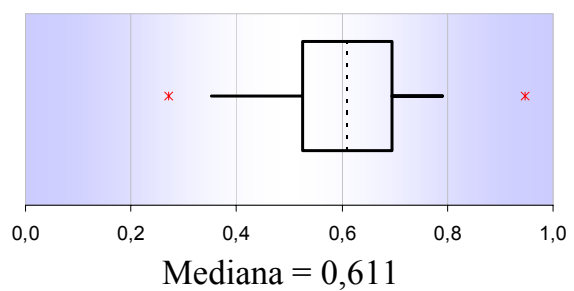

Estratégia 3

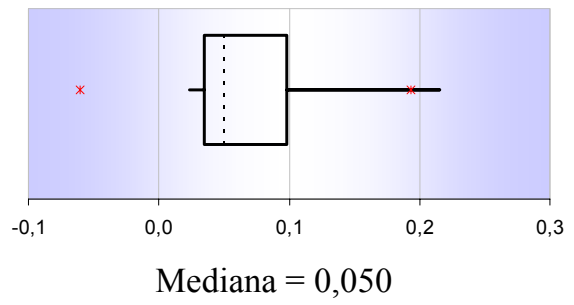

Estratégia 5

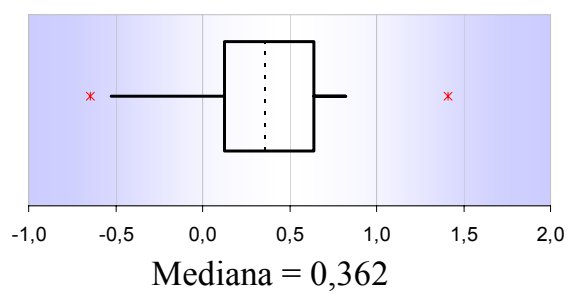

Estratégia 7

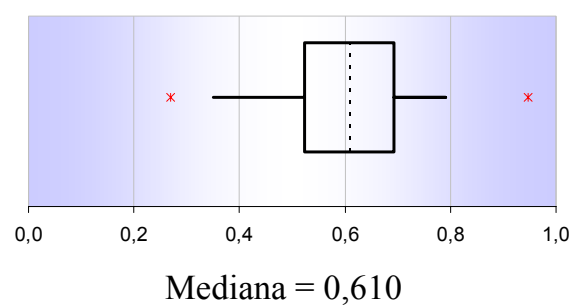

Estratégia 2

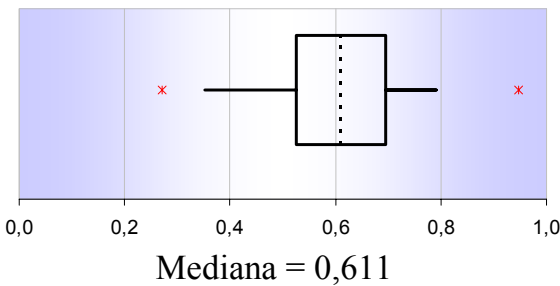

Estratégia 4

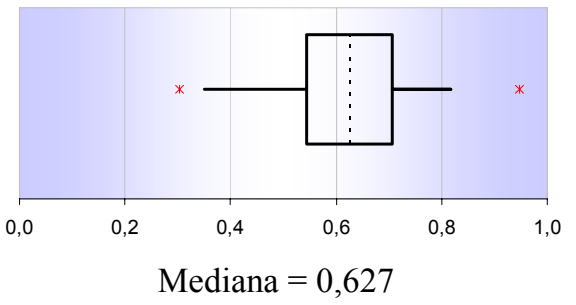

Estratégia 6

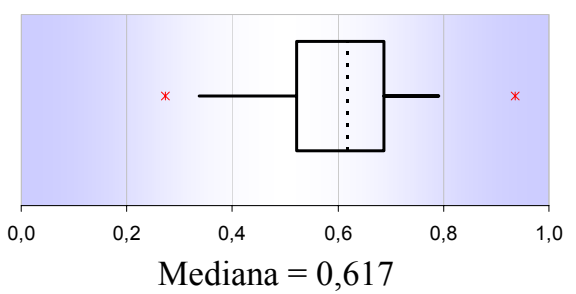

Estratégia 8

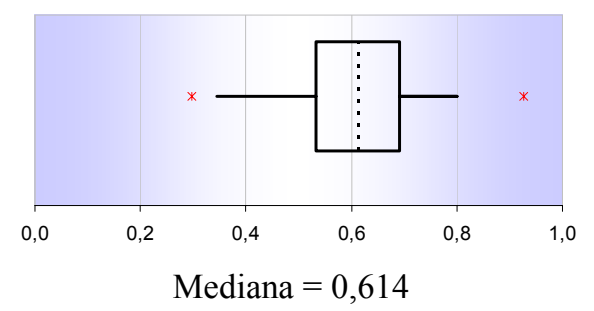

Figura 5 - Gráficos box-plot e medianas das medidas de eficácia para o café arábica

Observa-se pela figura 5, que a estratégia 4 apresentou a maior mediana quando comparada com as demais. Dessa forma, pode-se afirmar que ela é a mais eficaz para o café arábica. 


\subsubsection{Soja}

Analisando a medida de eficácia para a soja, nota-se pelo gráfico 14 que não há como afirmar haver uma estratégia superior as demais por unanimidade. Observa-se, no entanto, que as estratégias 1, 2, 4, 6, 7 e 8, têm um comportamento muito semelhante, diferente das demais, 3 e 5 . Dentre as estratégias que têm influência do parâmetro de aversão ao risco, 4 e 5, quando analisadas sob o ponto de vista do parâmetro 1.000 considerado nesse trabalho, nota-se que apresentaram um comportamento bastante divergente. A estratégia 5, apresentou maior variabilidade, mostrando-se ora eficaz ora não eficaz. Já a estratégia 4, mostrou-se praticamente idêntica ao comportamento das estratégias que não consideram o parâmetro de aversão ao risco em seu cômputo. Por fim, a estratégia 3, apresentou um comportamento plano e próximo a zero, ao longo do período analisado.

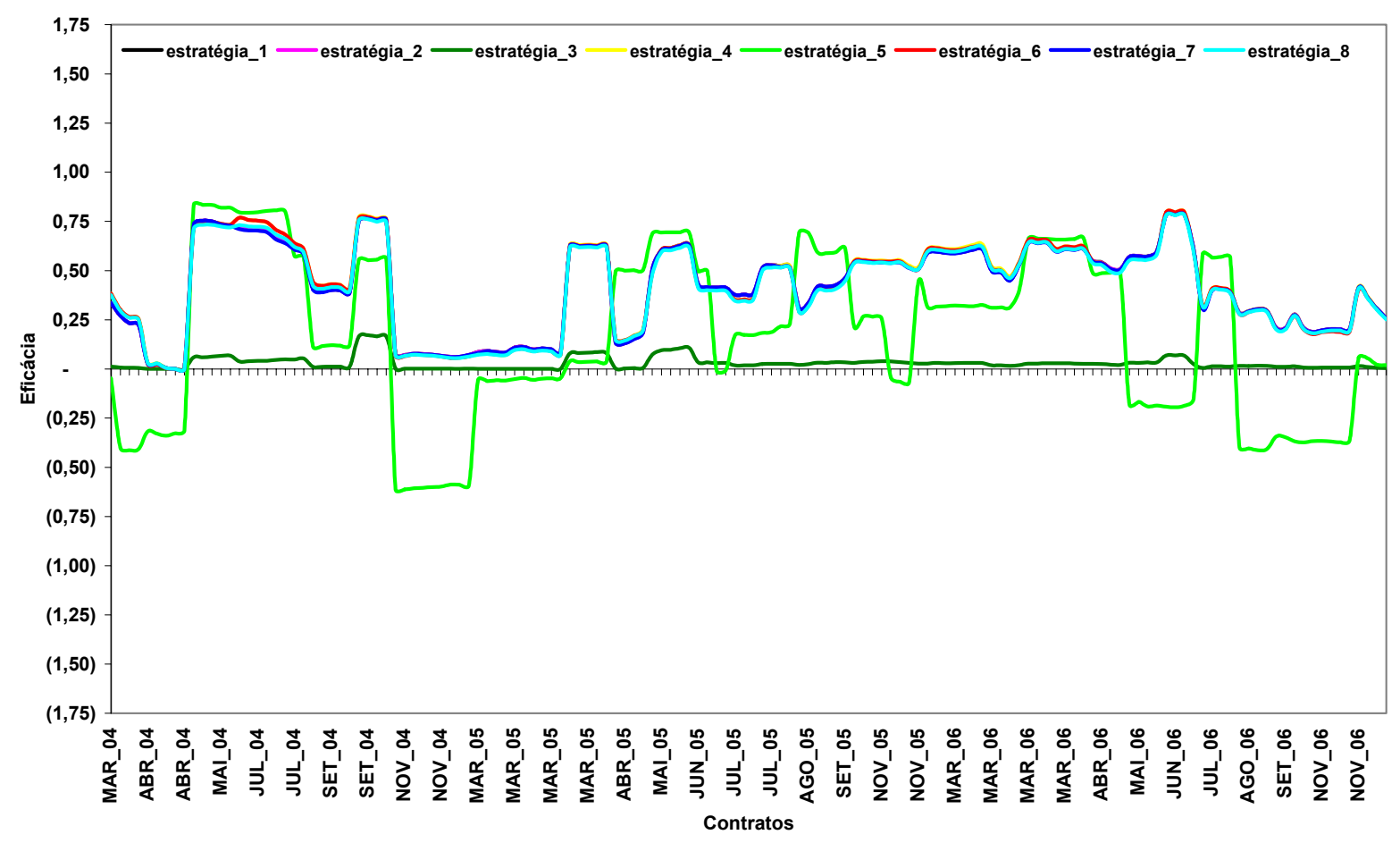

Gráfico 14 - Evolução das medidas de eficácia por estratégia para a soja

Com objetivo comparar estatisticamente a medida de eficácia das estratégias para a soja, realizou-se uma análise descritiva dos dados apresentada na figura 6 . 
Estratégia 1

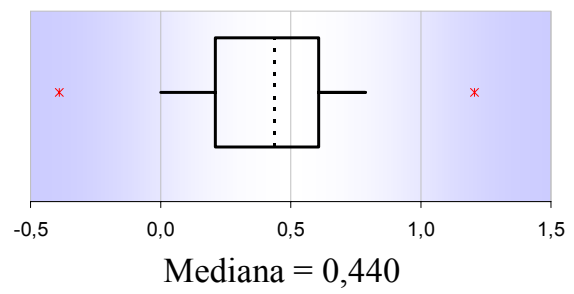

Estratégia 3

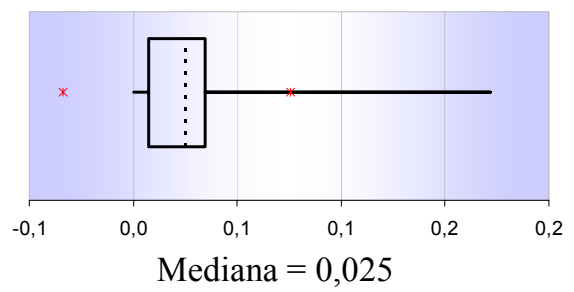

Estratégia 5

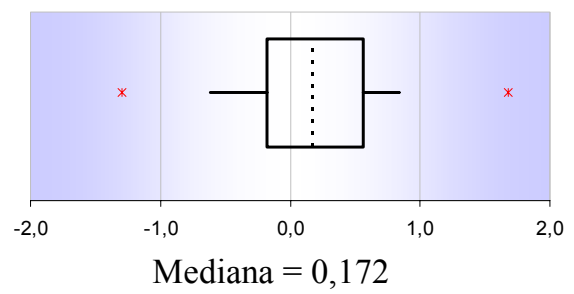

Estratégia 7

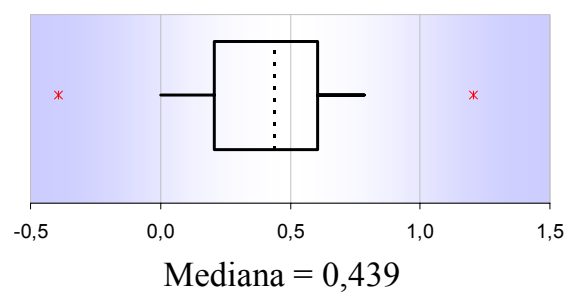

Estratégia 2

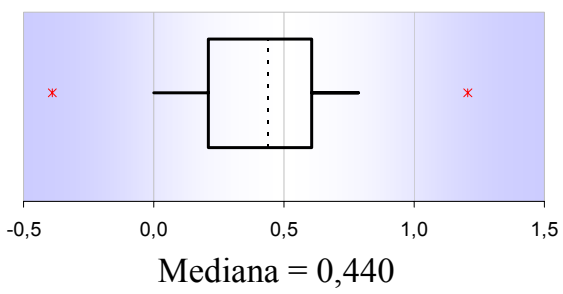

Estratégia 4

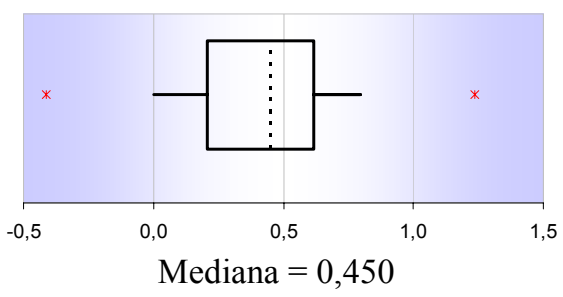

Estratégia 6

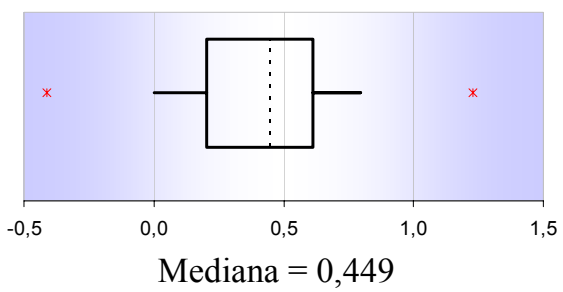

Estratégia 8

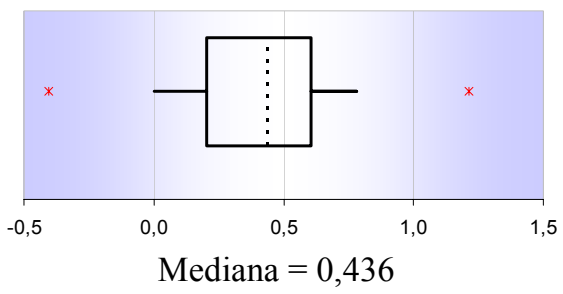

Figura 6 - Gráficos box-plot e medianas das medidas de eficácia para a soja

Observa-se pela figura 6 , que a estratégia 4 apresentou a maior mediana quando comparada com as demais. Dessa forma, pode-se afirmar que ela é a mais eficaz para a soja. 


\subsubsection{Dólar Comercial}

Analisando a medida de eficácia para o dólar comercial, nota-se pelo gráfico 15 que não há como afirmar haver uma estratégia superior as demais por unanimidade. Observa-se, no entanto, que as estratégias 1, 2, 4, 6, 7 e 8, têm um comportamento muito semelhante, diferente das demais, 3 e 5 . Dentre as estratégias que têm influência do parâmetro de aversão ao risco, 4 e 5, quando analisadas sob o ponto de vista do parâmetro 1.000 considerado nesse trabalho, nota-se que apresentaram um comportamento bastante divergente. A estratégia 5 , apresentou maior variabilidade, mostrando-se ora eficaz ora não eficaz, com destaque para o período compreendido entre os contratos de abril e julho de 2005. Já a estratégia 4, mostrou-se praticamente idêntica ao comportamento das estratégias que não consideram o parâmetro de aversão ao risco em seu cômputo. Por fim, a estratégia 3, apresentou um comportamento plano e próximo a zero, ao longo do período analisado.

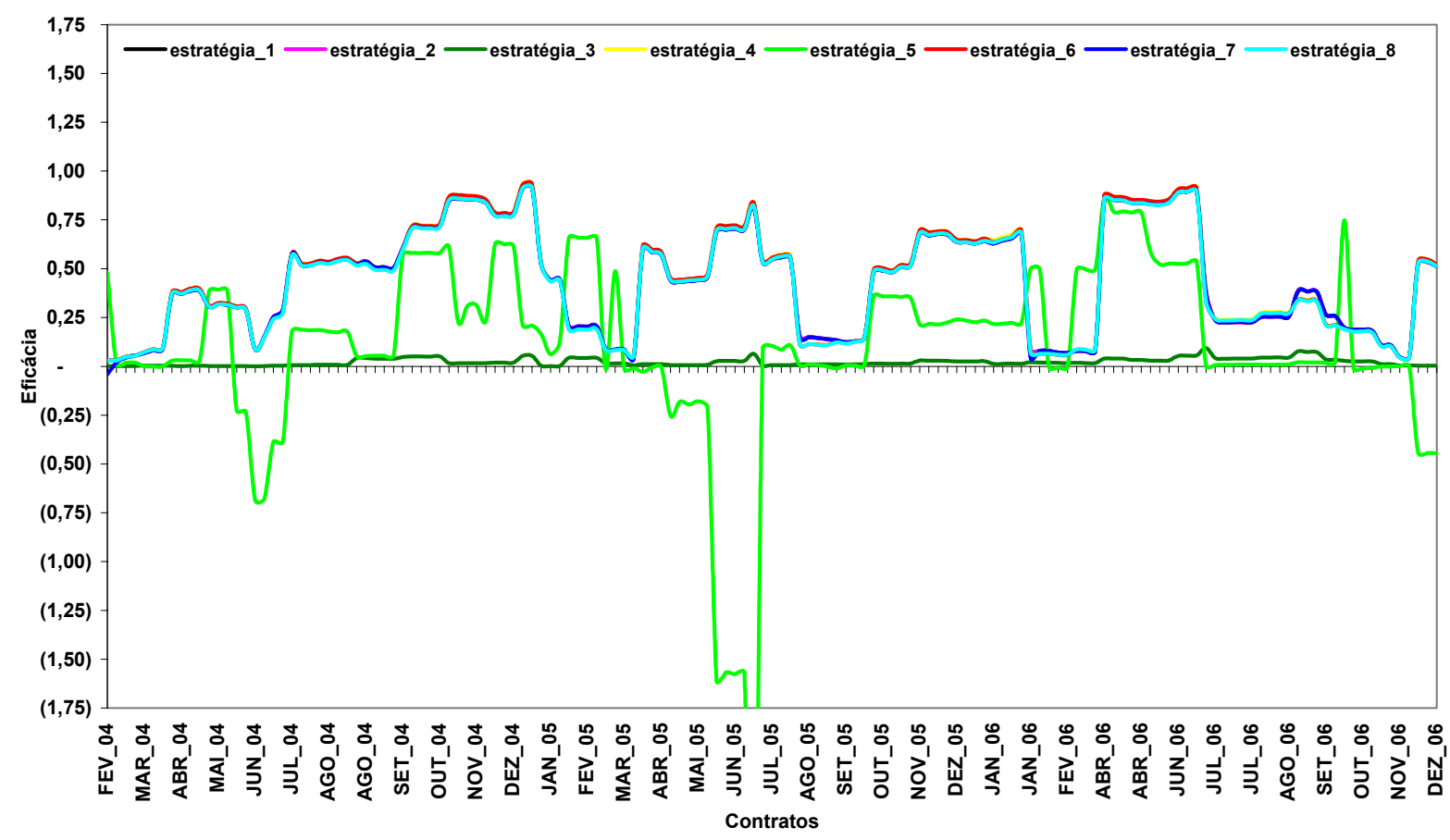

Gráfico 15 - Evolução das medidas de eficácia por estratégia para o dólar comercial

Com objetivo comparar estatisticamente a medida de eficácia das estratégias para o dólar comercial, realizou-se uma análise descritiva dos dados apresentada na figura 7 . 
Estratégia 1

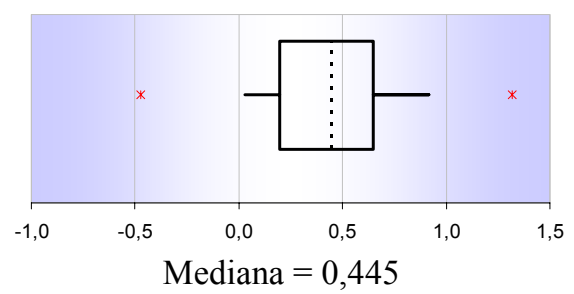

Estratégia 3

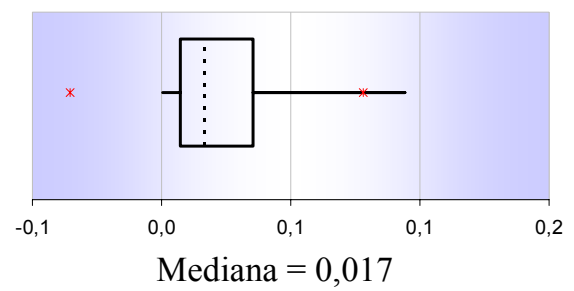

Estratégia 5

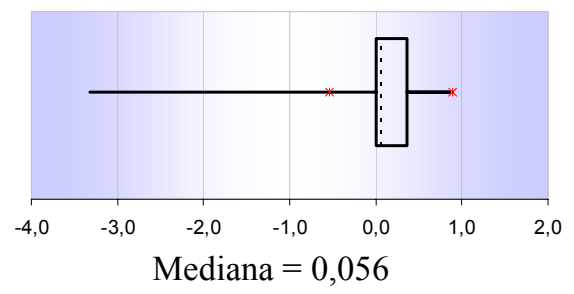

Estratégia 7

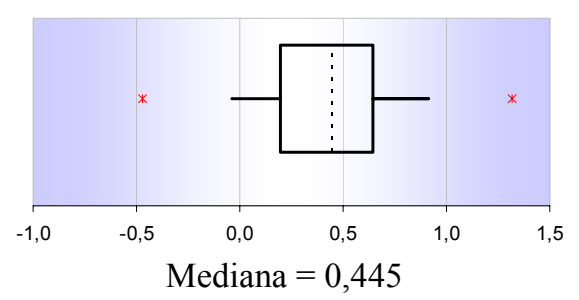

Estratégia 2

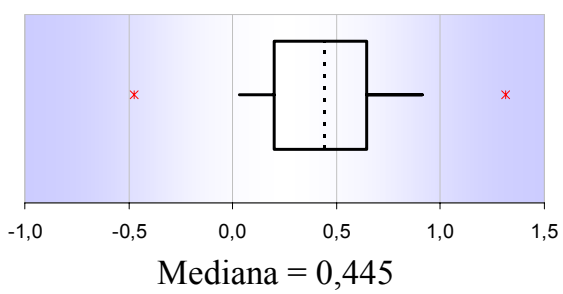

Estratégia 4

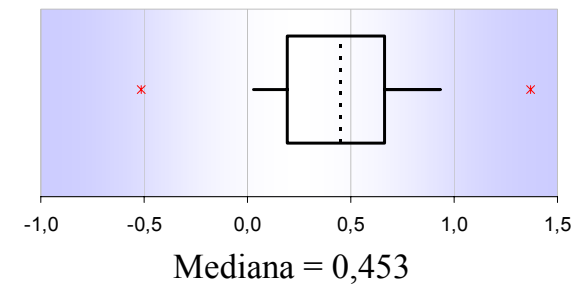

Estratégia 6

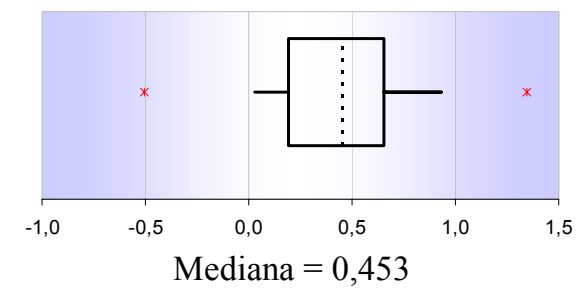

Estratégia 8

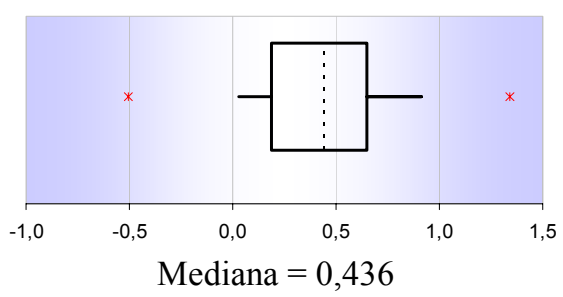

Figura 7 - Gráficos box-plot e medianas das medidas de eficácia para o dólar comercial

Observa-se pela figura 7, que as estratégias 4 e 6 apresentaram igualmente as maiores medianas quando comparada com as demais. Dessa forma, pode-se afirmar que elas são mais eficazes para o dólar comercial. 


\subsubsection{Ibovespa}

Analisando a medida de eficácia para o lbovespa, nota-se pelo gráfico 16 que não há como afirmar haver uma estratégia superior as demais por unanimidade. Observa-se, no entanto, que as estratégias 1, 2, 4, 6, 7 e 8, têm um comportamento muito semelhante, diferente das demais, 3 e 5 . Dentre as estratégias que têm influência do parâmetro de aversão ao risco, 4 e 5, quando analisadas sob o ponto de vista do parâmetro 1.000 considerado nesse trabalho, nota-se que apresentaram um comportamento bastante divergente. A estratégia 5, apresentou maior variabilidade, mostrando-se ora eficaz ora não eficaz. Já a estratégia 4, mostrou-se praticamente idêntica ao comportamento das estratégias que não consideram o parâmetro de aversão ao risco em seu cômputo. Por fim, a estratégia 3, apresentou um comportamento plano e próximo a zero, ao longo do período analisado.

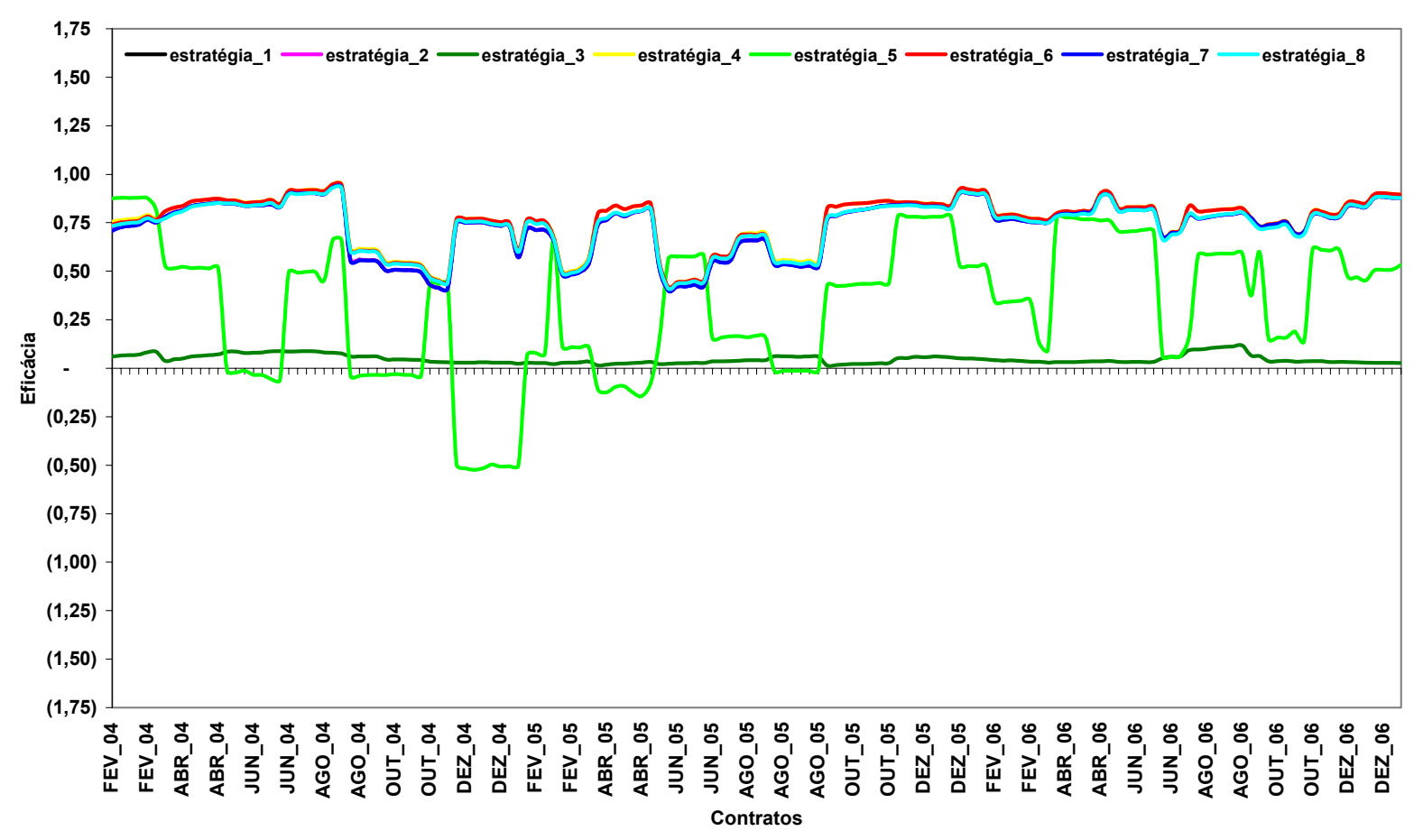

Gráfico 16 - Evolução das medidas de eficácia por estratégia para o lbovespa

Com objetivo comparar estatisticamente a medida de eficácia das estratégias para o Ibovespa, realizou-se uma análise descritiva dos dados apresentada na figura 8. 
Estratégia 1

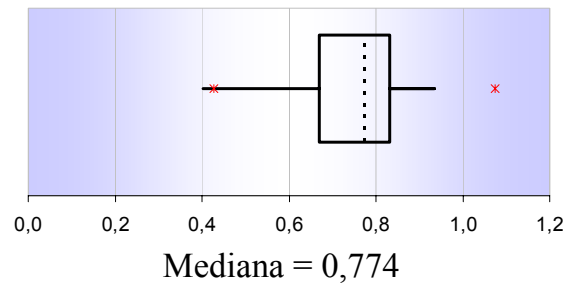

Estratégia 3

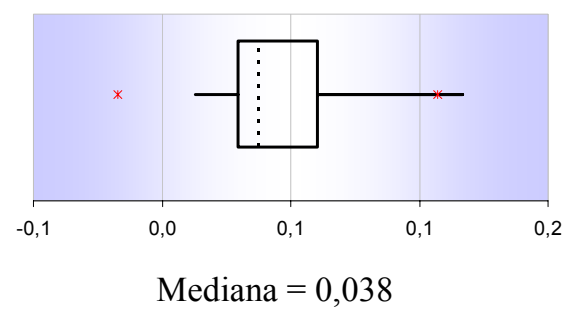

Estratégia 5

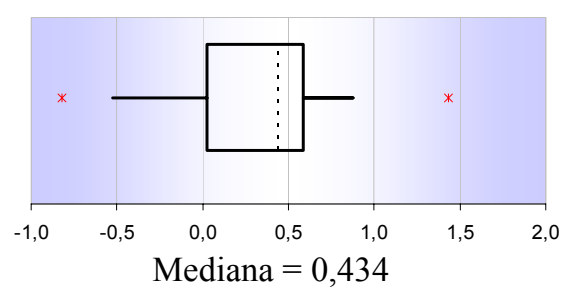

Estratégia 7

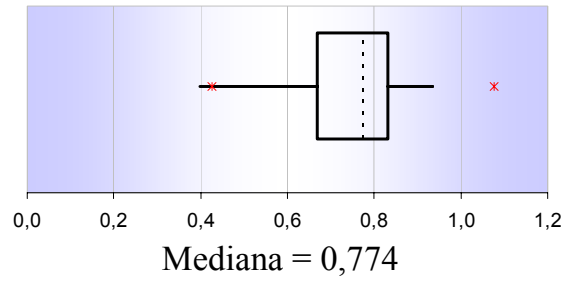

Estratégia 2

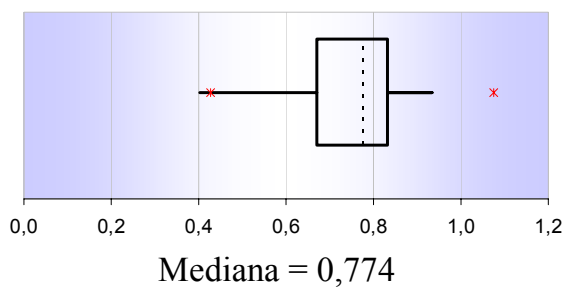

Estratégia 4

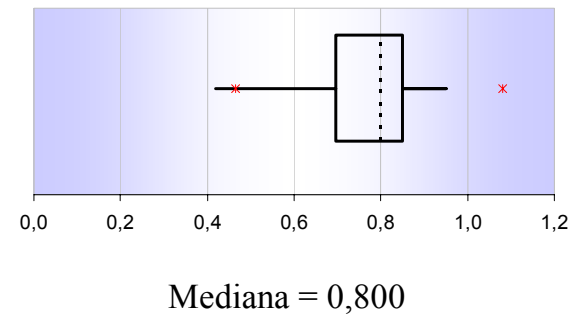

Estratégia 6

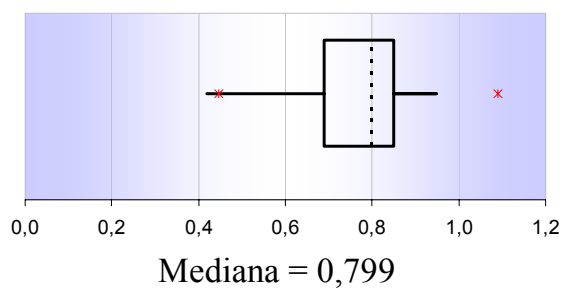

Estratégia 8

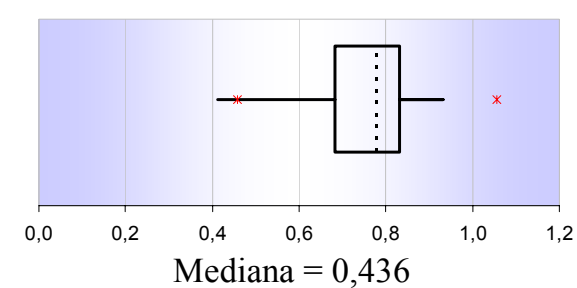

Figura 8 - Gráficos box-plot e medianas das medidas de eficácia para o Ibovespa

Observa-se pela figura 8, que a estratégia 4 apresentou a maior mediana quando comparada com as demais. Dessa forma, pode-se afirmar que ela é mais eficaz para o Ibovespa.

Conforme observado pelos gráficos em linha, que representam a evolução da medida de eficácia das estratégias analisadas, não há como afirmar haver uma 
estratégia superior às demais por unanimidade ao longo do período considerando, sobre os ativos analisados nesse estudo. No entanto, quando analisadas na forma de estatística descritiva, como representado pelas figuras que contém os gráficos box-plot e as medianas das medidas de eficácia das estratégias, nota-se que a estratégia 4 apresentou-se superior para a maioria dos ativos, com exceção do álcool anidro, que apresentou a estratégia 5. Outra evidência é que a mediana da estratégia 6 , apresentou-se também muito próxima à da estratégia 4 chegando a ser coincidentes para o dólar comercial e, para os demais ativos, com exceção do álcool anidro, a diferença entre elas mostrou-se muito pequena. 


\section{CONCLUSÕES FINAIS}

Este trabalho estudou estratégias estáticas de hedging para contratos futuros visando, à redução do risco financeiro em que incorrem produtores agrícolas. A opção pelo uso desses derivativos deveu-se não apenas devido à importância dos contratos futuros no mercado nacional e internacional, mas também à relevância, do ponto de vista conceitual, desse tipo de abordagem. Destaque-se que, embora a literatura apresente estratégias dinâmicas de hedging, as quais adotam modelos em tempo contínuo para determinar o número de contratos futuros a ser adquirido (ou vendido) de forma a reduzir os riscos, a determinação da melhor estratégia estática para situações particulares é ainda um problema em aberto.

Algumas hipóteses de trabalho, adotadas neste estudo, como a inexistência de custos de transação e de armazenagem, ou a inexistência de sazonalidade no mercado de commodities agrícolas, não comprometem o estudo. Uma premissa sobre a qual se baseou o cômputo dos resultados financeiros apresentados do trabalho é que o produtor agrícola, tendo posição comprada no ativo no mercado à vista, vende contratos no mercado futuro, com o objetivo de hedgear o risco de preço do ativo considerado. Naturalmente, esta premissa pode, ou não, ser adequada, de acordo com a tendência seguida pelos preços dos ativos considerados, uma vez que os ganhos ou as perdas financeiras por assumir tal posição são determinados pelo movimento dos preços futuro e à vista, ao longo do período em que o produtor opera o contrato. Assim, de forma a capturar movimentos e tendências de preços no mercado, reduzindo-se o impacto deles sobre a estratégia, optou-se por tratar as estratégias estáticas de forma dinâmica, realizando rebalanceamentos semanais.

Primeiramente, avaliaram-se os resultados financeiros brutos. O açúcar cristal, no período de análise considerado, apresentou resultados financeiros negativos para as estratégias, na maioria dos contratos analisados. Tais resultados foram coerentes com a premissa de assumir sempre posição vendida no mercado futuro, mesmo quando os preços apresentaram tendência de alta no período de vigência desses contratos. Da mesma forma, também ocorreram alguns resultados 
positivos, consistentes com a posição vendida nos contratos, quando a tendência de preços foi de queda no período que a vigência dos contratos compreendeu. De forma geral, os resultados financeiros negativos foram mais freqüentes que os positivos, contabilizando-se um resultado final negativo para o produtor, o que também ocorreu para o café arábica e para o lbovespa. No caso do álcool anidro, da soja e do dólar comercial, os resultados financeiros para as estratégias foram positivos na maioria dos contratos analisados. De forma geral como os resultados financeiros positivos foram mais freqüentes que os negativos, contabilizaram-se, nestes casos, um resultado final positivo para o produtor. Esses resultados sugerem que uma apropriada identificação de tendências dos mercados pode ser mais relevante na construção de estratégias de hedging do que a estrutura analítica das mesmas.

Já analisando-se os resultados financeiros obtidos com o emprego das diferentes estratégias para cada um dos ativos, não foi possível identificar a superioridade de uma estratégia em relação às demais para todos os ativos. Para o açúcar cristal, assim como para o Ibovespa, a estratégia de regressão linear, condicionada ao conjunto de informações, foi a que apresentou maior resultado financeiro em valor absoluto. Já para o álcool anidro, a estratégia de regressão, linear condicionada ao conjunto de informações e ao período de carregamento, foi a mais adequada, para o café arábica, a estratégia de maximização da utilidade esperada; para a soja, a estratégia de minimização do coeficiente de Gini estendido e para o dólar comercial, a estratégia de maximização da utilidade esperada. Notase que as estratégias por mínima variância, por regressão linear, por maximização da utilidade esperada, por regressão linear, condicionada ao conjunto de informações, por regressão linear, condicionada ao conjunto de informações e ao período de carregamento e por mínima variância, condicionada ao período de carregamento, apresentaram resultados financeiros muito próximos, quando considerados valores absolutos, divergindo das estratégias por maximização do índice de Sharpe e por minimização do coeficiente de Gini estendido, para todos os ativos.

Ao realizar a análise de variância por ativo, considerando os resultados financeiros obtidos por contrato, para cada estratégia, também não foi possível 
identificar diferença estatisticamente significativa entre as estratégias. De maneira similar, considerando cada uma das estratégias, não foi possível identificar diferença estatisticamente significativa entre os resultados financeiros médios dos ativos, decorrente do tipo de ativo considerado. Ou seja, não há indícios de que uma específica estratégia seja superior às demais ou de que diferentes ativos possuam peculiaridades que conduzam ao uso de estratégias particulares dentre as analisadas.

A eficácia das estratégias foi analisada através da mensuração da redução de risco, ou seja, determinou-se o quanto se obteve em termos de redução de risco ao construir o portfólio hedgeado em comparação ao risco considerando-se apenas a posição no mercado à vista. Exceto pelas estratégias de maximização do índice de Sharpe e de minimização do coeficiente de Gini estendido, as demais estratégias apresentaram um comportamento bastante semelhante ao longo do período estudado. Através de um estudo simplificado das medianas dos resultados de eficácia, pode-se observar uma aparente superioridade da estratégia por maximização da utilidade esperada para o açúcar cristal, o café arábica, a soja, o dólar comercial e o lbovespa e da estratégia por minimização do coeficiente de Gini estendido para o álcool anidro. Nota-se, também, que a estratégia de regressão linear, condicionada ao conjunto de informações, foi igualmente superior às demais para o dólar comercial.

Por fim, não foi possível identificar uma clara superioridade de alguma estratégia para o mercado brasileiro de commodities agrícolas. $\mathrm{O}$ investidor tem em mãos um conjunto de ferramentas e deverá levar em conta a medida de risco que considerar mais adequada à sua atividade, no momento de optar por uma estratégia particular de hedging. Os resultados são consistentes com o que se obtém em modelos de gestão de carteiras de ativos financeiros em que onde não há uma clara preponderância de um modelo sobre os demais. Uma extensão dos resultados aqui apresentados refere-se ao estudo desses modelos em cenários econômicos mais turbulentos, de forma a analisar a robustez das diferentes estratégias em situações adversas. Além disso, podem-se considerar modelos mais gerais, que incorporem custos de transação, peculiaridades dos mercados considerados e mesmo informações sobre tendências. 


\section{REFERÊNCIAS BIBLIOGRÁFICAS ${ }^{8}$}

BATALHA, M.O. Gestão agroindustrial, $1^{\text {a }}$ ed., São Paulo: Atlas, vol.1, 1997.

BELL, D.; KRASKER, W. Estimating Hedge Ratios. Financial Management, vol. 15, $n^{\circ} .2$, p. 34-39, 1986.

BHARGAVA, V.; MALHORDA, D. K. Determining the Optimal Hedge Ratio: Evidence from Cotton and Soybean Markets. Journal of Business \& Economic Studies, vol. 13, n 1, p. 38-57, 2007.

BODIE, Z.; KANE, A. and MARCUS, A. J. Essentials of Investments. $5^{a}$ ed., The McGraw-Hill Companies, 2003.

BRAILSFORD, T.; CORRIGAN, K.; HEANEY, R. A Comparison of Measures of Hedging Effectiveness: A Case Study Using the Australian All Ordinaries Share Price Index Futures Contract. Journal of Multinational Financial Management, vol. 11, $n^{\circ} .4$, p. 465-481, 2001.

CASTELINO, M. G. Minimum-Variance Hedging with Futures Revisited. The Journal of Portfolio Management, vol. 16, nº. 3, p. 74-80, 1990.

CASTRO, A. M. G. Análise da Competitividade de Cadeias Produtivas. Palestra Apresentada no Workshop: Cadeias Produtivas e Extensão Rural na Amazônia, EMBRAPA, Manaus, 2000.

CECCHETTI, S. G.; CUMBY, R. E.; FIGLEWSKI, S. Estimation of the Optimal Futures Hedge. The Review of Economics and Statistics, vol. 70, n⿳ 4, p. 623-630, 1988.

CHANG, J. S. K.; SHANKER, L. A Risk-Return Measure of Hedging Effectiveness: a comment. Journal of Financial and Quantitative Analysis, vol. 22, $n^{\circ} .3$, p. 373-376, 1987.

CHEN, S. S.; LEE, C.F.; SHRESTHA, K. Futures Hedge Ratios: a review. The Quarterly Review of Economics and Finance, vol. 43, p. 433-465, 2003.

CHEUNG, C. S., KWAN, C. C. Y.; YIP, P. C. Y. The Hedging Effectiveness of Options and Futures: a Mean-Gini Approach. Journal of Futures Markets, vol. 10, $n^{\circ} .1$, p. $61-73,1990$.

CHEUNG, C.S., KWAN, C. Y., MIU, P. C. Mean-Gini Portfólio Analysis: a pedagogic Illustration. DeGroote School of Business McMaster University, May 10, p. 194-207, 2007.

\footnotetext{
${ }^{8}$ Elaborada de acordo com as normas ABNT NBR 6023 (2002), com devidas adaptações à literatura da área de Engenharia.
} 
CHISHOLM, A. M. Derivatives Demystified: a step-by-step guide for forwards, futures, swaps \& options. John Wiley \& Sons Ltda, 2004.

DAVIS, J. H.; GOLDBERG, R. A. A Concept of Agribusiness. Journal of Farm Economics, vol. 39, nº 4, p. 1042-1045, 1957.

DEMIRER, R.; LIEN, D.; SHAFFER, D. R. Comparisons of Short and Long Hedge Performance: the Case of Taiwan. Journal of Multinational Financial Management, vol. 15, no. 1, p. 51-66, 2005.

DORFMAN, R. A Formula de Gini Coefficient. The Review of Economics and Statistics, vol. 61, nº1, p. 146-149, 1979.

EDERINGTON, L. H. The Hedging Performance of the New Futures Markets. The Journal of Finance, vol. 34, nº 1, p. 157-170, 1979.

EUROPEAN COMMISSION AGRICULTURE DIRECTORATE-GENERAL, Risk Management Tools for EU Agriculture: with a special focus on insurance, january 2001.

FAMA, E. F.; FRENCH, K. R. Commodity Futures Prices: some evidence on forecast power, premiums and the theory of storage. Journal of Business, vol. $60, \mathrm{n}^{\circ}$ 1, p. 55-73, 1987.

FIGUEIREDO, A. C. Introdução aos Derivativos. São Paulo: Pioneira Thomson Learning, 2002.

GEMAN, H.; NGUYEN, V.N. Soybean Inventory and Forward Curves Dynamics. Management Science, vol. 51, n 7, p. 1076-1091, 2002.

GEMAN, H. Commodities and Commodity Derivatives: modeling and pricing for agriculturals, metals and energy, John Wiley \& Sons Ltda, 2005.

GIL, A. C. Como Elaborar Projetos de Pesquisa. 3ª ed., São Paulo: Atlas, 1991.

GITMAN, L. J. Princípios de Administração Financeira. São Paulo: Harba, 1984.

HARDAKER, J. B.; HUIRNE, R. B. M.; ANDERSON, J. R.; G. LIEN. Coping with risk in agriculture. $2^{\mathrm{a}}$ ed., CABI Publishing, 2004

HILLIARD, J. E. Hedging Interest Rates Risk with Futures Portfolios under Term Structure Effects. The Journal of Finance, vol. 39, nº 5, p. 1547-1569, 1984.

HOWARD, C.T.; D'ANTONIO L. J. A Risk-Return Measure of Hedging Effectiveness: a reply. The Journal of Financial and Quantitative Analysis, vol. 22, $\mathrm{n}^{\circ}$ 3, p. 377-381, 1987.

A Risk-Return Measure of Hedging Effectiveness. The Journal of Financial and Quantitative Analysis, vol. 19, n¹, p. 101-112, 1984. 
HSIN, C.W., KUO, J.; LEE, C. F. A New Measure to Compare the Hedging Effectiveness of Foreign Currency Futures versus Options. Journal of Futures Markets, vol. 14, n. 6, p. 685-690, 1994.

HULL, J. C. Introdução aos Mercados Futuros e de Opções. $2^{a}$ ed., Tradução: Bolsa de Mercadorias \& Futuros, 1986.

Options, Futures, \& Others Derivatives. $5^{\mathrm{a}}$ ed., Prentice Hall, 2003.

JARQUE, C. M.; BERA, A. K. Efficiente Tests, for Normality, Homoscedasticity and Serial Independence of Regression Residuals. Economics Letters, vol. $6, \mathrm{n}^{\circ}$. 3, p. 255-259, 1980.

A test for Normality of Observations and Regression Residual. International Statistical Review/Revue Internationale de Statistique, vol. 55, $\mathrm{n}^{\circ} 2$, p. 163-172, 1987.

JOHNSON, L.L. The Theory of Hedging and Speculation in Commodity Futures. The Review of Economics Studies, vol. 27, n. 3, p. 139-151, 1960.

JUNKUS, J. C.; LEE, C. F. Use of three index futures in hedging decisions. Journal of Futures Markets, vol. 5, nº. 2, p. 201-222, 1985.

KOLB, R.W.; OKUNEV, J. An Empirical Evaluation of the Extended Mean-Gini Coefficient for Futures Hedging. The journal of futures markets, vol. 12, $\mathrm{n}^{\circ} .2, \mathrm{p}$. 177-186, 1992.

. Utility Maximizing Hedge Ratios in the Extended Mean Gini Framework. Journal of Futures Markets, vol. 13, n. 6, p. 597-609, 1993.

KUO, C. K.; Chen, K. W. A Risk-Return Measure of Hedging Effectiveness: a simplification. Journal of Futures Markets, vol. 15, n. 1, p. 39-44, 1995.

LAKATOS, E. M.; MARCONI, M. A. Fundamentos de Metodologia Científica. $4^{a}$ ed., São Paulo: Atlas, 1993.

LIEN, D.; LUO, X. Estimating the Extended Mean-Gini Coefficient for Futures Hedging. Journal of Futures Markets, vol. 13, n. 6, p. 665-676, 1993.

LIEN, D.; SHAFFER, D. R. A Note on Estimating the Minimum Extended Gini Hedge Ratio. The journal of Futures Markets, vol. 19, n 1, p. 101-113, 1999.

LUENBERGER, D. Investment Science. Oxford University Press. Inc., 1988.

MASSEY JR., F. J. The Kolmogorov-Smirnov Test for Goodness of Fit. Journal of the American Statistical Association, vol. 46, n² 253, p. 68-78, 1951.

MEUWISSEN, M.P.M.; HUIRNEA, R.B.M., AND HARDAKER, J.B. Income insurance in European agriculture. European Economy, n² 2, Luxembourg, 1999. 
Risk and risk management: an empirical analysis of Dutch livestock farmers. Livestock production science, vol. 69, nº. 1, p. 43-53, 2001.

MORAES, M. A. F. D.; SHIKIDA, P. F. A. (ORGANIZADORES) Agroindústria Canavieira no Brasil: evolução, desenvolvimento e desafios. São Paulo: Atlas, 2002.

MYERS, R.; THOMPSON, S. Generalized Optimal Hedge Ratio Estimation. American Journal of Agricultural Economics, vol. 71, nº 4, p. 858-868, 1989.

PRATT, J. W. Risk Aversion in the Small and in the Large. Econometrica, vol. 32, $\mathrm{n}^{\circ} 1-2$, p. 122-136, January-April, 1964.

ROTHSCHILD, M.; STIGLITZ, J.E. Increasing Risk I: a definition. Journal of Economic Theory, vol. 2, nº. 3, p. 225-43, 1970.

SATYANARAYAN, S. A Note on a Risk-Return Measure of Hedging Effectiveness. The Journal of Futures Markets, vol. 18, nº. 7, p. 867-870, 1998.

SHALIT, H. Mean-Gini Hedging in futures markets. The Journal of Future Markets, vol. $15, n^{\circ} 6$, p. 617-635, 1995.

SHALIT, H.; YITZHAKI, S. Mean-Gini, Portfolio Theory, and the Pricing of Risky Assets. The Journal of Finance, vol. 39, n. 5, p. 1449-1468, 1984.

SHARPE, W. F.; ALEXANDER, G. J.; BAILEY, J. V. Investments, $6^{a}$ ed., Prentice Hall, 1998.

SILVA, E. L.; MENEZES, E. M. Metodologia da Pesquisa e Elaboração de Dissertação. $3^{a}$ ed., Florianópolis: Laboratório de Ensino a Distância da UFSC, 2001, 121p. Disponível em: < http://projetos.inf.ufsc. br/arquivos/Metodologia\%20da\%20Pesquisa\%203a\%20edicao .pdf $>$ acesso em 02/jan/2008.

SILVA, L. C. Cadeia Produtiva de Produtos Agrícolas. Universidade Federal do Espírito Santo, Departamento de Engenharia Rural, Boletim Técnico: MS: 01/05 em 21/04/2005.

SIQUEIRA, T. V. A Cultura do Café: 1961 - 2005. Parte 1, parte 2 e parte 3, BNDES Setorial, 2005/09.

O Ciclo da Soja: desempenho da cultura da soja entre 1961 e 2003 . Parte 1 e parte 2, BNDES Setorial, 2004/09.

SOLOMN, E.; PRINGLE, J. J. Introdução à Administração Financeira. São Paulo: Atlas, 1981.

STEIN, J. The Simultaneous Determination of Spot and Futures Prices. The American Economic Review, vol. 51, n. 5, p. 1012-1025, 1961. 
UNICAMP-IE-NEIT - NÚCLEO DE ECONOMIA INDUSTRIAL E DA TECNOLOGIA DA UNIVERSIDADE ESTADUAL DE CAMPINAS, 2002. Estudos da Competitividade de Cadeias Integradas no Brasil: impactos das zonas de livre comércio. Cadeia: Café

USDA: MARKET and TRADE ECONOMICS DIVISION and RESOURCE ECONOMICS DIVISION, ECONOMIC RESEARCH SERVICE, U.S. DEPATMENT of AGRICULTURE, 1999. Managing risk in farming: concepts, research and analysis, Agricultural Economic Report, 774, Washington, D.C.

VARIAN, H. R. Microeconomia: princípios básicos. São Paulo: Campus, Tradução da $5^{\mathrm{a}}$ ed. Americana, 2000.

VIAN, C. E. F. Agroindústria Canavieira: estratégias competitivas e modernização. Campinas - SP: Átomo, 2003.

VISWANATH, P. V. Efficient Use of Information, Convergence Adjustments, and Regression Estimates of Hedge Ratios. The Journal of Futures Markets, vol. 13, $n^{\circ} .1$, p. 43-53, 1993.

WATANABE, K. The contractual relation in agribusiness. Scuola superiori Sant' Anna di Pisa, 2005. Disponível em: <http://esnie.u-paris10.fr/pfd/st 2005/watanabe papier.doc>. Acesso em 18/12/2007.

WILLIAMS, J. C.; WRIGHT, B. D. Storage and Commodity Markets. Cambridge University Press, 1991.

WORKING, H. Futures Trading and Hedging. The American Economic Review, vol. 43, no. 3, p. 314-343, 1953.

YITZHAKI, S. Gini's Mean Difference: a superior measure of variability for nonnormal distributions. Metron - International Journal of Statistics, vol. LXI, $n^{\circ} 2, p$. 285-316, 2003.

On an Extension of the Gini Inequality Index. International Economic Review, vol. 24, nº 3, p. 617-628, 1983.

Stochastic Dominance, Mean Variance, and Gini's Mean Difference. The American economic review, vol. 72, no. 1, p. 178-185, 1982.

ZYLBERSZTAJN, D. Estruturas de Governança e Coordenação do Agribusiness: uma nova aplicação da nova economia das instituições. 1995, 239 p., Tese de Livre Docência, Departamento de Administração da Faculdade de Economia, Administração e Contabilidade da Universidade de São Paulo, 1995. 


\section{REFERÊNCIAS CONSULTADAS}

ANDERSON, R. W.; AND DANTHINE, J. P. Hedging and Joint Production: Theory and Illustrations. Journal of Finance, vol. 35, n'. 2, p. 487-498, 1980.

BENNINGA, S.; ELDOR, R.; ZILCHA, I. Optimal Hedging in the Futures Market under Price Uncertainty. Economics Letters, vol. 13, nº. 2-3, p. 155-159, 1983.

The Optimal Hedge Ratio in Unbiased Futures Markets. The Journal of Future Markets, vol. 4, p. 155-159, 1984.

DURBIN, J. Erros in Variables. International Statistical Review, vol. 22, p. 23-32, 1954.

ELTON, E. J., GRUBER, M.J. Modern Portfolio Theory and Investment Analysis. $5^{\text {a }}$ ed., John Wiley \& Sons, 1995.

FAMÁ, R.; CARDOSO, R. L.; MENDONÇA, O. Riscos Financeiros e Não Financeiros: uma proposta de modelo para finanças. Cadernos da FACECA, Campinas, vol. 11, p. 33-50, jan./jun. 2002.

FEIBEL, B.J. Investment Performance Measurement. The Frank Fabozzi series, John Willey \& Sons Inc., p.186-187, 2003.

FIGLEWSKI, S. Hedging Performance and Basis Risk in Stock Index Future. The Journal of Finance, vol. 39, n 3, p. 657-669, 1983.

GJERDE, O. Measuring Hedging Effectiveness in a Traditional One-Period Portfolio Framework. The Journal of Futures Markets, vol. 7, p. 663-674, 1987.

GUJARATI, D. Basic Econometrics. Fourth edition, The McGraw-hill Companies, 2004.

HODGSON, A.; OKUNEV, J. An Alternative Approach for Determining Hedge Ratio for Futures Contracts. Journal of Business Finance \& Accounting, vol. 19, $\mathrm{n}^{\circ}$ 2, p. 211-224, 1992.

JORION, P. Value at Risk: a nova fonte de referência para a gestão do risco financeiro. Ed. $2^{\circ}$ revisada e ampliada, Tradução: Bolsa de Mercadorias \& Futuros, São Paulo, 2003.

KNIGHT, F. H. Risk, Uncertainty, and Profit. Boston: Houghton Mifflin, 1921.

LERMAN, R. I.; YITZHAKI, S. A Note on the Calculation and Interpretation of the Gini index. Economics Letters, vol. 15, n. 3-4, p. 363-368, 1984.

LIEN, D.; SHRESTHA, K. Hedging Effectiveness Comparisons: a note. International Review of Economics and Finance, xx, p. 1-6, 2007. 
LINDAHL, M. Risk-Return Hedging Effectiveness Measures for Stock Index Futures. The Journal of Futures Markets, vol.11, n² 4, p. 399-409, 1991.

MORETIN, P. A. Econometria Financeira. Departamento de Estatística do Instituto de Matemática e Estatística da Universidade de São Paulo. 2004.

NICOLAU, I. O Conceito de Estratégia. ISCTE, 2001. Disponível em: < http://pcc5301.pcc.usp.br/PCC\%205301\%202005/Bibliografia $\% 202005 /$ Conceito $\% 20$ Estrat\%C3\%A9gia\%20(Nicolau).pdf > acesso em 05/jan/2008.

OLIVEIRA, S.L. Tratado de Metodologia Científica: projetos, TGI, TCC, monografias, dissertações e teses. São Paulo: Pioneira Thomson Learning, 2001.

SECURATO, J. R. Decisões Financeiras em Condições de Risco. $2^{\circ}$ ed., São Paulo: Saint Paul Ltda, 2007.

SHAFFER, D. R. Estimating the Gini hedge ratio. Managerial Finance, vol. $29, \mathrm{n}^{\circ}$. 1, p. 73-84, 2003.

SHAFFER, D. R.; DEMASKEY, A. Currency Hedging Using the Mean-Gini Framework. Review of Quantitative Finance and Accounting, vol. 25, $n^{\circ}$. 2, p. 125137, 2005.

SHAPIRO, S. S.; WILK, M. B. An Analysis of Variance Test for Normality (Complete Samples). Biometrika, vol. 52, p. 591-611, 1965.

TOEVS, A.; JACOB, D. Futures and Alternative Hedge Ratio Methodologies. Journal of Portfolio Management, vol. 12, n. 2, p. 60-70, 1986. 


\section{SITES CONSULTADOS}

Banco Central: < https://www3.bcb.gov.br/sgspub/localizarseries/localizar Series.do?method=prepararTelaLocalizarSeries $>$

BM\&F: < http://www3.bmf.com.br/Datarestore1/Indexseries1.asp >

CEPEA: < http://cepea.esalq.usp.br/ >

Illovosugar: < http://www.illovosugar.com/worldofsugar/international SugarStats.htm 


\section{APÊNDICE - CONCEITO DE DOMINÂNCIA ESTOCÁSTICA}

\section{Dominância Estocástica}

O conceito de dominância estocástica propõe mostrar, analiticamente, quando uma determinada variável aleatória é "melhor" que outra. Luenberger (1997, p.141), define variável aleatória como uma quantidade que pode ser tomada aleatoriamente sob um conjunto de valores específicos dentro de um intervalo finito, ao qual é associada uma probabilidade, que é sua chance de ocorrência. Para incertezas representadas por resultados únicos, como riqueza ou lucro financeiro, a variável aleatória pode ser descrita pela função de distribuição acumulada. Tal função reúne todas as informações relevantes necessárias da variável aleatória, permitindo realizar comparações entre duas delas.

Rothschild e Stiglitz (1970) e Yitzhaki (1982) discorrem, respectivamente, sobre as premissas necessárias para fundamentar quando uma variável aleatória é considerada mais "variável" que outra e quando ela domina estocasticamente outra. Considerem-se duas variáveis aleatórias definidas no intervalo [a,b], as quais têm suas funções de distribuição acumulada definidas por F e G. Para comparar quando uma função de distribuição acumulada é "melhor" que outra, para determinado indivíduo, deve-se construir a utilidade esperada de tais funções, dentro do intervalo considerado. As utilidades esperadas são, então, definidas por:

$$
\mathrm{U}(\mathrm{F})=\int_{\mathrm{a}}^{\mathrm{b}} \mathrm{u}(\mathrm{x}) \mathrm{dF}(\mathrm{x}) \quad \text { e } \quad \mathrm{U}(\mathrm{G})=\int_{\mathrm{a}}^{\mathrm{b}} \mathrm{u}(\mathrm{x}) \mathrm{dG}(\mathrm{x})
$$

Em que:

$\mathrm{U}($.$) : função utilidade esperada de VonNeumann - Morgenstern;$

$\mathrm{u}($.$) : função utilidade elementar.$

Dessa forma, se $\mathrm{U}(\mathrm{F}) \geq \mathrm{U}(\mathrm{G})$, então $\mathrm{F}$ é preferível a $\mathrm{G}$ para o indivíduo. Podese, portanto, afirmar que, se todo indivíduo prefere F a G, F domina G. 
Conforme definido por Rothschild e Stiglitz (1970), dado $\mathrm{U}^{0}$ como o conjunto de todas as funções utilidade elementar $u$, tal que $u: x \rightarrow \Re$ seja monotonicamente crescente, sendo $\geq_{1}$ uma relação transitiva e binária incompleta da função de distribuição acumulada sobre $x$, pode-se dizer que $F$ domina $G$ se para todo $\mathrm{u} \in \mathrm{U}^{0}, \mathrm{~F} \geq_{1} \mathrm{G}$. Assim, a variável aleatória com distribuição acumulada $\mathrm{F}$ domina a distribuição acumulada $G$, se todos os indivíduos que têm uma função utilidade monotonicamente crescente, acreditam que $F$ seja melhor que $G$. Sobre esta consideração, define-se o primeiro grau de dominância estocástica:

Diz-se que $F$ domina $G$, ou $F \geq_{1} G$ se, e somente se, $F(x) \leq G(x)$ para todo $\mathrm{x} \in[\mathrm{a}, \mathrm{b}]$.

Pode-se afirmar que, se $\mathrm{F}$ é preferível a $\mathrm{G}$, de acordo com o critério de primeiro grau de dominância estocástica, então a utilidade esperada de $\mathrm{F}$ é maior que a utilidade esperada de $\mathrm{G}$, para qualquer indivíduo com uma função utilidade monotonicamente crescente. Tem-se, então, a seguinte proposição:

$$
\mathrm{F} \geq_{1} G \Leftrightarrow \int_{a}^{b} u(x) d F(x) \geq \int_{a}^{b} u(x) d G(x) \quad \text { para todo } u \in U^{0}
$$

O propósito do primeiro grau de dominância estocástica é permitir ordenar preferência de distribuições, de acordo com retorno. No entanto, se ambas as distribuições tiverem a mesma média, $\mathrm{F}$ e $\mathrm{G}$ terão o mesmo retorno esperado.

Se uma distribuição de probabilidade é menos dispersa que outra, deveria ser considerada menos arriscada. Dessa forma, comparar dispersão entre as distribuições é outro critério de comparação de dominância, pelo menos para o indivíduo avesso ao risco.

O critério de segunda ordem de dominância estocástica permite hierarquizar distribuições na questão de risco, em termos de dispersão da distribuição de probabilidade. Considera-se que a distribuição de probabilidade acumulada de $\mathrm{F} \mathrm{e}$ de $\mathrm{G}$ seja caracterizada de acordo com o gráfico 17 : 


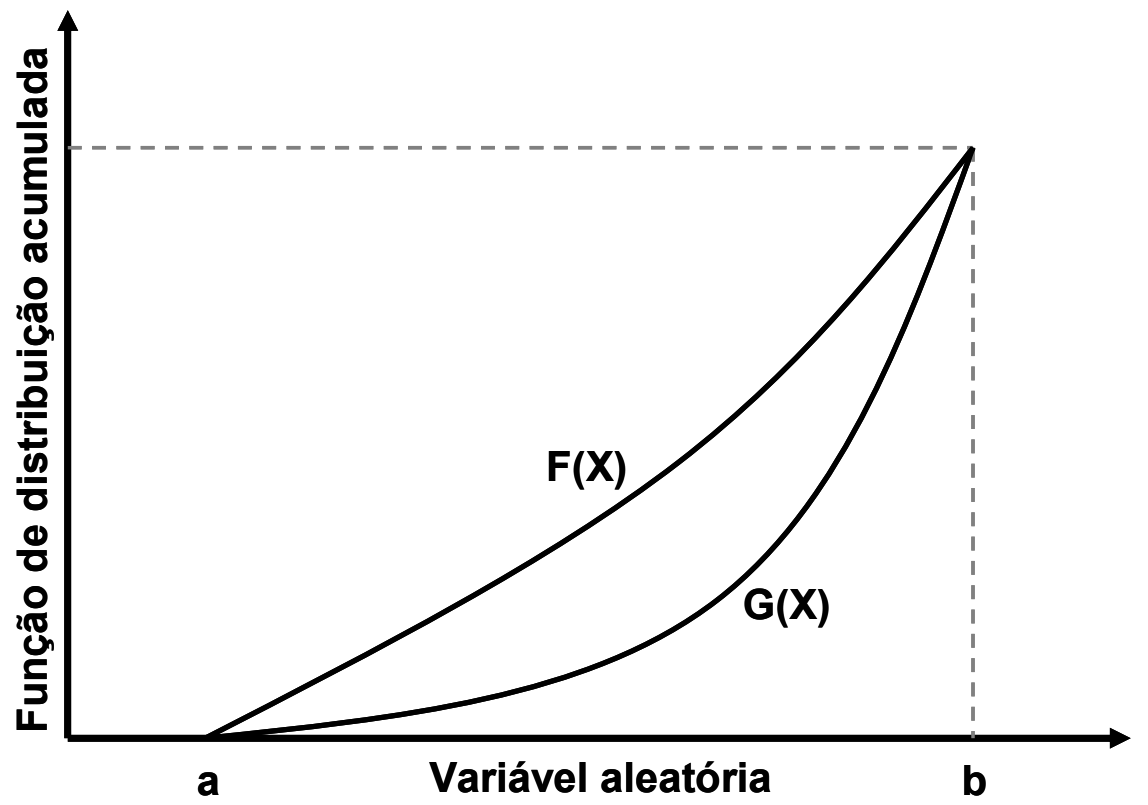

Gráfico 17 - Representação gráfica de dominância estocástica

Define-se $\mathrm{T}(\mathrm{x})$ como a área entre as duas curvas de $\mathrm{F}$ e $\mathrm{G}$ no intervalo [a,b], dada por:

$$
T(x)=\int_{a}^{b}[G(x)-F(x)] d x
$$

Como a curva $\mathrm{F}(\mathrm{x})$ está acima de $\mathrm{G}(\mathrm{x})$, tem-se $\mathrm{T}(\mathrm{x})>0$, pela expressão (A.3). Portanto, se $\mathrm{T}(\mathrm{x})>0$ para todo $\mathrm{x} \in[\mathrm{a}, \mathrm{b}]$, então se pode afirmar que $\mathrm{F}$ é mais disperso que $G$, implicando que $F$ seja mais arriscado que $G$.

Considerando o segundo grau de dominância estocástica, diz-se que F domina $G$, ou $F \geq_{2} G$ se, e somente se, $T(x)=\int_{a}^{b}[G(x)-F(x)] d t \geq 0$ para todo $\mathrm{x} \in[\mathrm{a}, \mathrm{b}]$. Tem-se, então, a seguinte proposição:

Sendo $\mathrm{U}^{1}$ o conjunto de todas as funções utilidades côncavas crescentes sobre $[a, b]$, então $F \geq_{2} G$ se, e somente se, $\int_{a}^{b} u(x) d F(x) \geq \int_{a}^{b} u(x) d G(x)$ para todo $\mathrm{u} \in \mathrm{U}^{1}$. 
Dessa forma, segundo Rothschild e Stiglitz (1970), F é mais arriscado que G se a média da distribuição $F$ for igual à média da distribuição $G, \mu_{F}=\mu_{G}$, mas se para todo $u \in U^{1}$, tem-se $\int_{a}^{b} u(x) d F(x) \geq \int_{a}^{b} u(x) d G(x)$. 


\section{ANEXOS - TESTE DE NORMALIDADE}

\section{TESTE DE NORMALIDADE}

Os testes de normalidade mais freqüentemente apresentados e utilizados são os de Kolmogorov-Smirnov, Shapiro-Wilk e Jarque-Bera. Massey (1951) apresentou o teste de Kolmogorov-Smirnov que propunha verificar se os resíduos de uma regressão tinham distribuição normal. Shapiro e Wilk apresentaram um trabalho no qual propunham um teste para mostrar se as observações de uma determinada variável aleatória provinham de uma distribuição normal. Semelhante ao teste de Kolmogorov-Smirnov, Jarque e Bera (1980), usando o multiplicador de Lagrange, apresentaram um procedimento que propunha um teste para determinar se os resíduos de uma regressão linear tinham uma distribuição normal. Esse teste era simples de realizar e assintoticamente distribuído, segundo a distribuição de Chiquadrado, $\chi^{2}$.

\section{Normalidade das Observações}

Jarque e Bera, baseados no método do multiplicador de Lagrange, definem o valor da estatística utilizada para testar a hipótese de que as observações seguem uma distribuição normal, como:

$$
\mathrm{ML}_{\mathrm{o}}=\mathrm{N}\left[\frac{\left(\sqrt{\mathrm{b}_{1}}\right)^{2}}{6}+\frac{\left(\mathrm{b}_{2}-3\right)^{2}}{24}\right]
$$

Em que:

$\mathrm{ML}_{\mathrm{o}}$ : valor da estatística;

$\mathrm{N}$ : número de observações;

$\mathrm{b}_{1}$ : medida de assimetria da distribuição;

$\mathrm{b}_{2}$ : medida de curtose da distribuição.

O valor dessa estatística é utilizado para realizar o seguinte teste de hipótese: 
$\mathrm{H}_{0}$ : as observações seguem uma distribuição normal;

$\mathrm{H}_{1}$ : as observações não seguem uma distribuição normal.

Onde $b_{1}$ e $b_{2}$ são, respectivamente, as medidas de assimetria e curtose da distribuição, definidas como, $b_{1}=\frac{\hat{\mu}_{3}^{2}}{\hat{\mu}_{2}^{3}}$ e $b_{2}=\frac{\hat{\mu}_{4}}{\hat{\mu}_{2}^{2}}$, com $\hat{\mu}_{j}=\frac{\sum_{i=1}^{N}\left(X_{i}-\bar{X}\right)^{j}}{N}$, sendo $M_{0}$ assintoticamente distribuído como $\chi_{(2)}^{2}$. Segundo os autores, a hipótese nula será rejeitada, para $\mathrm{ML}_{\mathrm{o}}$ maiores que o valor crítico $\chi_{(2)}^{2}$, determinado pelo nível de significância considerado no teste.

\section{Normalidade dos Resíduos}

Jarque e Bera (1987, p. 166) consideram, para a definição do teste estatístico de normalidade, um modelo de regressão linear com os resíduos $\varepsilon_{\mathrm{i}}$, independentes e identicamente distribuídos, com a média da população igual a zero e função densidade de probabilidade definida por $\mathrm{f}\left(\varepsilon_{\mathrm{i}}\right)$.

Sobre tais considerações, os autores definem o valor da estatística utilizada para testar a hipótese de que os resíduos da regressão seguem uma distribuição normal, como:

$$
\mathrm{ML}_{\mathrm{r}}=\mathrm{N}\left[\frac{\left(\sqrt{\hat{\mathrm{b}}_{1}}\right)^{2}}{6}+\frac{\left(\hat{\mathrm{b}}_{2}-3\right)^{2}}{24}\right]
$$

Em que:

$\mathrm{ML}_{\mathrm{r}}$ : valor da estatística;

$\mathrm{N}$ : número de observações;

$\mathrm{b}_{1}$ : medida de assimetria da distribuição;

$\mathrm{b}_{2}$ : medida de curtose da distribuição. 
O valor dessa estatística é utilizado para realizar o seguinte teste de hipótese:

$\mathrm{H}_{0}$ : os resíduos seguem uma distribuição normal;

$\mathrm{H}_{1}$ : os resíduos não seguem uma distribuição normal.

Onde $\hat{b}_{1}$ e $\hat{b}_{2}$, são, respectivamente, as medidas de assimetria e curtose da distribuição definidas como, $\hat{b}_{1}=\frac{\hat{\mu}_{3}^{2}}{\hat{\mu}_{2}^{3}}$ e $b_{2}=\frac{\hat{\mu}_{4}}{\hat{\mu}_{2}^{2}}$, com $\hat{\mu}_{\mathrm{j}}=\frac{\sum_{\mathrm{i}=1}^{\mathrm{N}}\left(\varepsilon_{\mathrm{i}}\right)^{\mathrm{j}}}{\mathrm{N}}$, sendo $\mathrm{ML}_{\mathrm{r}}$ assintoticamente distribuído como $\chi_{(2)}^{2}$.

Jarque e Bera afirmaram ser de grande importância certificar-se de que os resíduos de uma regressão linear fossem normalmente distribuídos, pois a violação de normalidade poderia levar à obtenção de estimadores ineficientes ou não-ótimos, além de afirmações inferenciais não válidas e de conclusões não-acuradas.

\section{Resultados dos testes estatísticos de normalidade}

Os resultados sobre a normalidade do conjunto de dados, foram obtidos por meio dos testes estatísticos $\mathrm{ML}_{\mathrm{o}}$ e $\mathrm{ML}_{\mathrm{r}}$, baseados na distribuição de Chi-quadrado considerando-se grau de liberdade 2, como originalmente proposto por Jarque e Bera (1987).

As hipóteses testadas, tanto para as observações quanto para os resíduos das regressões lineares, foram:

$\mathrm{H}_{0}$ : as observações / os resíduos seguem uma distribuição normal; $\mathrm{H}_{1}$ : as observações / os resíduos não seguem uma distribuição normal.

Considerando-se uma probabilidade $p$ de $5 \%$ para os testes, o valor crítico tabelado para $\chi_{(2)}^{2}$ é 5,991 . Sendo assim, se $\mathrm{ML}_{\mathrm{o}}>5,991$, rejeita-se a hipótese nula, que, caso contrário será aceita, da mesma forma que $\mathrm{ML}_{\mathrm{r}}$. 
Adotou-se uma nomenclatura para caracterizar sobre qual conjunto de dados a estatística de Lagrange foi obtida, conforme mostrado na tabela 27.

Tabela 27 - Nomenclatura para os testes estatísticos com o multiplicador de Lagrange

\begin{tabular}{cc}
\hline Nomenclatura & Definição \\
\hline MLps & Multiplicador de Lagrange sobre preços à vista \\
MLpf & Multiplicador de Lagrange sobre preços futuro \\
MLvs & Multiplicador de Lagrange sobre a variação dos preços à vista \\
MLvf & Multiplicador de Lagrange sobre a variação dos preços futuro \\
MLrets & Multiplicador de Lagrange sobre retornos do preço à vista \\
MLretf & Multiplicador de Lagrange sobre retornos do preço futuro \\
Mlress & Multiplicador de Lagrange sobre resíduos da regressão simples \\
Mlresm6 & Multiplicador de Lagrange sobre resíduos da regressão múltipla da estratégia 6 \\
Mlresm7 & Multiplicador de Lagrange sobre resíduos da regressão múltipla da estratégia 7 \\
\hline
\end{tabular}

A tabela 28 mostra a proporção do conjunto de dados que foi considerado seguir uma distribuição normal sobre a ótica do teste de Lagrange. Essa proporção foi determinada da relação do número de contratos que aceitaram a hipótese nula, frente o número total de contratos dentro do período de análise considerado no trabalho.

Tabela 28 - Proporção de conjunto de dados considerados seguir uma distribuição normal

\begin{tabular}{|c|c|c|c|c|c|c|c|c|c|}
\hline Ativos & MLps & MLpf & MLvS & MLvf & MLrets & MLretf & MIress & MIresm6 & MIresm7 \\
\hline Açúcar & $0,0 \%$ & $6,7 \%$ & $0,0 \%$ & $0,0 \%$ & $6,7 \%$ & $6,7 \%$ & $0,0 \%$ & $13,3 \%$ & $6,7 \%$ \\
\hline Álcool & $17,1 \%$ & $37,1 \%$ & $0,0 \%$ & $11,4 \%$ & $0,0 \%$ & $11,4 \%$ & $0,0 \%$ & $0,0 \%$ & $0,0 \%$ \\
\hline Café Arábica & $0,0 \%$ & $6,7 \%$ & $0,0 \%$ & $40,0 \%$ & $0,0 \%$ & $40,0 \%$ & $0,0 \%$ & $6,7 \%$ & $6,7 \%$ \\
\hline Soja & $36,4 \%$ & $13,6 \%$ & $13,6 \%$ & $4,5 \%$ & $18,2 \%$ & $9,1 \%$ & $31,8 \%$ & $13,6 \%$ & $36,4 \%$ \\
\hline Dólar Comercial & $20,6 \%$ & $8,8 \%$ & $2,9 \%$ & $2,9 \%$ & $2,9 \%$ & $0,0 \%$ & $8,8 \%$ & $8,8 \%$ & $8,8 \%$ \\
\hline Ibovespa & $44,4 \%$ & $50,0 \%$ & $27,8 \%$ & $72,2 \%$ & $27,8 \%$ & $77,8 \%$ & $5,6 \%$ & $0,0 \%$ & $5,6 \%$ \\
\hline
\end{tabular}

As tabelas de 29 a 34 apresentam os resultados estatísticos do teste de Lagrange. 
Tabela 29 - Resultados da estatística de Lagrange para o açúcar cristal

\begin{tabular}{|c|c|c|c|c|c|c|c|c|c|}
\hline Contratos & MLps & MLpf & MLvs & MLvf & MLrets & MLretf & MIress & MIresm6 & MIresm7 \\
\hline FEV_04 & 22,54 & 9,57 & 11,28 & 9,54 & 3,19 & 31,38 & 6,98 & 114,45 & 7,42 \\
\hline ABR_04 & 22,33 & 11,98 & 27,00 & 258,68 & 15,21 & 245,39 & 34,77 & 210,92 & 36,65 \\
\hline JUL_04 & 18,05 & 14,03 & 45,90 & 903,31 & 19,76 & 385,32 & 48,07 & 157,62 & 112,05 \\
\hline SET_04 & 19,17 & 15,73 & 67,91 & 39,78 & 37,93 & 66,88 & 74,28 & 78,32 & 217,04 \\
\hline NOV_04 & 23,04 & 14,39 & 83,82 & 65,69 & 57,30 & 107,15 & 79,59 & 20,87 & 229,57 \\
\hline FEV_05 & 46,02 & 21,25 & 89,69 & 69,95 & 94,00 & 85,16 & 89,61 & 126,96 & 263,47 \\
\hline ABR_05 & 123,77 & 627,92 & 200,06 & 184,51 & 225,86 & 106,54 & 201,44 & 388,85 & $1.076,78$ \\
\hline JUL_05 & 65,31 & 19,88 & 95,49 & $1.074,52$ & 79,66 & $1.371,97$ & 98,26 & 115,74 & 200,17 \\
\hline SET_05 & 36,20 & 7,58 & 75,02 & 10,99 & 68,45 & 8,86 & 76,66 & $5.946,67$ & 162,94 \\
\hline NOV_05 & 9,08 & 3,64 & 177,75 & 206,20 & 167,07 & 107,42 & 180,22 & $-3,80$ & 525,21 \\
\hline FEV_06 & 46,25 & 31,27 & 102,64 & 69,29 & 150,69 & 13,28 & 85,22 & 296,89 & 230,48 \\
\hline ABR_06 & 23,07 & 17,48 & 63,95 & 76,74 & 87,10 & 18,39 & 57,94 & 29,25 & 107,65 \\
\hline JUL_06 & 32,16 & 28,02 & 75,84 & 26,57 & 133,55 & 8,33 & 74,23 & 16,75 & 125,99 \\
\hline SET_06 & 65,50 & 25,94 & 12,75 & 7,18 & 36,03 & 4,06 & 10,14 & $3.004,54$ & 4,62 \\
\hline NOV_06 & 29,44 & 24,51 & 40,09 & 140,42 & 53,85 & 68,44 & 40,20 & 0,44 & 18,27 \\
\hline
\end{tabular}

Tabela 30 - Resultados da estatística de Lagrange para álcool anidro

\begin{tabular}{|c|c|c|c|c|c|c|c|c|c|}
\hline Contratos & MLps & MLpf & MLvs & MLvf & MLrets & MLretf & MIress & MIresm6 & MIresm7 \\
\hline FEV_04 & 10,12 & 16,31 & 625,63 & $1.006,20$ & 633,42 & $2.988,90$ & 546,45 & 29,23 & $4.695,49$ \\
\hline MAR_04 & 55,34 & 46,43 & $4.129,53$ & 42,08 & $9.097,26$ & 237,65 & $4.344,52$ & 489,71 & $73.138,27$ \\
\hline ABR_04 & 26,10 & 15,74 & $3.726,97$ & 15,35 & $6.193,16$ & 17,75 & $4.172,11$ & $51.715,79$ & $85.038,89$ \\
\hline MAl_04 & 17,54 & 13,79 & $4.690,73$ & 106,65 & $6.796,28$ & 45,99 & $4.913,30$ & $54.175,89$ & $109.255,13$ \\
\hline JUN_04 & 12,50 & 5,62 & 754,34 & 3,29 & 680,40 & 3,36 & 704,75 & $13.022,74$ & $6.413,44$ \\
\hline JUL_04 & 10,58 & 4,88 & $1.632,50$ & 0,21 & $1.476,53$ & 0,92 & $1.390,30$ & 40,22 & $20.342,04$ \\
\hline AGO_04 & 9,09 & 3,71 & $1.820,32$ & 0,92 & $2.024,70$ & 2,42 & $1.526,13$ & 53,66 & $24.873,60$ \\
\hline SET_04 & 12,15 & 7,99 & $1.776,82$ & 4,83 & $1.320,01$ & 23,69 & $1.674,49$ & 263,93 & $22.254,52$ \\
\hline OUT_04 & 10,44 & 10,01 & $1.399,22$ & 13,15 & $1.616,95$ & 22,05 & $1.387,19$ & 118,71 & $16.555,85$ \\
\hline NOV_04 & 2,95 & 5,47 & $2.017,13$ & 34,86 & $3.643,06$ & 28,59 & $1.991,73$ & $1.972,43$ & $27.312,44$ \\
\hline DEZ_04 & 4,54 & 7,20 & $2.463,83$ & 923,57 & $6.020,20$ & 638,05 & $2.448,59$ & $60.140,62$ & $39.767,29$ \\
\hline JAN_05 & 7,77 & 11,79 & $2.124,01$ & 114,46 & $3.701,88$ & 119,24 & $2.062,65$ & 82,80 & $33.392,86$ \\
\hline FEV_05 & 6,26 & 6,48 & 682,27 & 77,95 & 723,01 & 73,15 & 677,61 & 470,28 & $4.980,37$ \\
\hline MAR_05 & 1,27 & 2,91 & 626,45 & 66,24 & 655,28 & 60,85 & 580,91 & 42,56 & $4.298,74$ \\
\hline ABR_05 & 8,27 & 2,92 & $1.389,45$ & 24,87 & $1.224,51$ & 24,84 & $1.079,77$ & 33,03 & $12.340,73$ \\
\hline MAl_05 & 10,05 & 41,78 & $2.078,38$ & 55,66 & $3.495,78$ & 52,86 & $2.075,22$ & 98,99 & $15.868,92$ \\
\hline JUN_05 & 12,46 & 9,65 & 719,92 & 20,91 & 943,60 & 26,58 & 705,97 & $328.579,10$ & $7.622,35$ \\
\hline JUL_05 & 13,14 & 8,90 & 798,72 & 32,37 & 952,97 & 31,42 & 796,12 & 43,16 & $9.861,98$ \\
\hline AGO_05 & 6,55 & 6,87 & 824,05 & 12,94 & 873,15 & 19,00 & 863,07 & $165.375,76$ & $9.596,39$ \\
\hline SET_05 & 11,54 & 6,12 & $1.343,11$ & 57,19 & $1.382,08$ & 47,57 & $1.288,71$ & $398.648,84$ & $21.869,79$ \\
\hline OUT_05 & 3,04 & 1,01 & $1.386,21$ & 6,06 & $1.138,95$ & 5,58 & $1.369,53$ & $272.945,52$ & $20.103,21$ \\
\hline NOV_05 & 6,61 & 3,44 & $1.617,20$ & 109,91 & $1.477,69$ & 83,66 & $1.615,23$ & 61,62 & $24.884,37$ \\
\hline DEZ_05 & 11,19 & 4,15 & $1.682,65$ & 12,21 & $1.703,87$ & 19,05 & $1.640,12$ & 74,43 & $23.003,28$ \\
\hline JAN_06 & 9,49 & 11,42 & $2.232,85$ & 80,47 & $1.877,95$ & 75,77 & $2.009,18$ & 90,77 & $29.113,65$ \\
\hline FEV_06 & 2,14 & 6,91 & $1.168,06$ & 69,81 & $1.152,85$ & 60,27 & $1.164,96$ & 54,35 & $15.787,84$ \\
\hline MAR_06 & 1,53 & 9,53 & $1.004,26$ & 105,74 & 999,94 & 105,58 & 995,47 & 68,64 & $11.360,99$ \\
\hline ABR_06 & 8,35 & 1,77 & 685,12 & 171,09 & 661,27 & 174,40 & 683,74 & $1.112 .770,23$ & $8.981,04$ \\
\hline MAl_06 & 9,38 & 8,90 & $1.007,24$ & 23,95 & 969,54 & 28,65 & 616,00 & $1.698 .350,72$ & $6.630,61$ \\
\hline JUN_06 & 10,97 & 2,97 & $4.868,93$ & 46,05 & $4.541,74$ & 29,57 & $4.917,72$ & 44,73 & $153.701,13$ \\
\hline JUL_06 & 14,10 & 5,60 & $7.182,78$ & 60,38 & $6.465,58$ & 43,28 & $7.127,67$ & 71,66 & $246.072,12$ \\
\hline AGO_06 & 15,78 & 5,43 & $10.421,18$ & 99,33 & $9.315,41$ & 85,04 & $10.353,92$ & 67,58 & $405.972,92$ \\
\hline SET_06 & 14,56 & 7,79 & $10.724,26$ & 56,83 & $8.448,00$ & 34,92 & $10.527,60$ & 32,06 & $426.625,76$ \\
\hline OUT_06 & 23,08 & 8,23 & $11.405,32$ & 167,08 & $8.312,29$ & 140,31 & $11.769,88$ & 26,27 & $476.565,65$ \\
\hline NOV_06 & 20,15 & 7,39 & $20.992,31$ & 176,65 & $15.346,20$ & 152,83 & $21.103,07$ & 106,03 & $1.104 .776,68$ \\
\hline DEZ_06 & 27,24 & 11,08 & $32.014,99$ & 204,17 & $23.247,67$ & 129,06 & $31.953,80$ & 703,47 & $1.945 .629,69$ \\
\hline
\end{tabular}


Tabela 31 - Resultados da estatística de Lagrange para o café arábica

\begin{tabular}{|c|c|c|c|c|c|c|c|c|c|}
\hline Contratos & MLps & MLpf & MLvS & MLvf & MLrets & MLretf & MIress & MIresm6 & MIresm7 \\
\hline MAR_04 & 23,60 & 20,20 & 16,84 & 18,77 & 15,30 & 16,01 & 42,03 & 25,17 & 134,49 \\
\hline MAI_04 & 24,20 & 20,77 & 16,12 & 22,68 & 16,89 & 18,96 & 49,18 & 43,07 & 74,80 \\
\hline JUL_04 & 25,32 & 27,72 & 12,66 & 29,99 & 8,83 & 27,72 & 19,13 & 18,26 & 40,46 \\
\hline SET_04 & 17,75 & 27,30 & 13,28 & 16,15 & 9,55 & 13,59 & 47,32 & 20,36 & 52,33 \\
\hline DEZ_04 & 22,74 & 29,82 & 44,98 & 105,15 & 20,41 & 48,36 & 113,80 & 25,98 & 103,59 \\
\hline MAR_05 & 48,61 & 72,69 & 12,15 & 57,31 & 8,39 & 22,29 & 7,70 & 38,17 & 2,18 \\
\hline MAl_05 & 12,56 & 7,70 & 23,43 & 3,62 & 6,66 & 3,88 & 14,78 & 207,56 & 7,29 \\
\hline JUL_05 & 8,17 & 2,60 & 25,00 & 3,36 & 12,07 & 3,71 & 14,00 & 55,29 & 12,14 \\
\hline SET_05 & 14,99 & 16,61 & 29,26 & 3,77 & 17,54 & 1,66 & 40,38 & 218,74 & 44,88 \\
\hline DEZ_05 & 20,85 & 19,22 & 37,19 & 4,47 & 27,18 & 2,35 & 47,66 & 169,52 & 78,43 \\
\hline MAR_06 & 19,64 & 25,57 & 46,74 & 27,89 & 35,00 & 7,08 & 137,26 & 284,18 & 398,35 \\
\hline MAl_06 & 18,38 & 10,15 & 47,77 & 4,53 & 53,43 & 1,94 & 15,08 & 4,52 & 9,23 \\
\hline JUL_06 & 16,21 & 9,61 & 95,14 & 16,75 & 100,60 & 7,05 & 11,25 & 21,61 & 12,94 \\
\hline SET_06 & 72,11 & 83,32 & 170,16 & 159,84 & 89,83 & 19,28 & 754,64 & 551,33 & $5.819,76$ \\
\hline DEZ 06 & 26,18 & 52,24 & 49,67 & 0,57 & 44,33 & 0,11 & 44,41 & 28,57 & 87,50 \\
\hline
\end{tabular}

Tabela 32 - Resultados da estatística de Lagrange para a soja

\begin{tabular}{|c|c|c|c|c|c|c|c|c|c|}
\hline Contratos & MLps & MLpf & MLvs & MLvf & MLrets & MLretf & MIress & MIresm6 & MIresm7 \\
\hline MAR_04 & 14,04 & 13,79 & 21,30 & 196,89 & 35,97 & 178,38 & 23,89 & 3,08 & 21,88 \\
\hline ABR_04 & 15,96 & 10,66 & 10,62 & 11,88 & 21,20 & 21,14 & 5,67 & 5,17 & 3,02 \\
\hline MAl_04 & 9,09 & 5,53 & 13,04 & 14,00 & 14,10 & 3,24 & 15,94 & 38,00 & 14,29 \\
\hline JUL_04 & 6,19 & 5,37 & 9,54 & 8,62 & 16,63 & 8,63 & 17,67 & $4.341,63$ & 23,06 \\
\hline SET_04 & 6,16 & 6,53 & 5,94 & 111,54 & 5,90 & 142,25 & 5,43 & 803,57 & 1,08 \\
\hline NOV_04 & 8,13 & 11,07 & 14,00 & 92,90 & 8,11 & 65,76 & 0,87 & 5,76 & 0,16 \\
\hline MAR_05 & 12,89 & 46,86 & 22,73 & 29,22 & 14,28 & 36,07 & 18,29 & 395,44 & 18,47 \\
\hline ABR_05 & 6,13 & 29,36 & 14,51 & 47,08 & 6,56 & 47,66 & 34,86 & 62,17 & 118,60 \\
\hline MAl_05 & 12,80 & 11,09 & 13,80 & 50,07 & 6,89 & 27,48 & 13,86 & 333,03 & 26,88 \\
\hline JUN_05 & 7,10 & 12,30 & 16,99 & 89,93 & 7,94 & 43,86 & 54,19 & 61,40 & 156,59 \\
\hline JUL_05 & 10,40 & 9,14 & 12,32 & 91,91 & 5,56 & 63,43 & 10,89 & 56,84 & 12,61 \\
\hline AGO_05 & 9,74 & 12,64 & 36,90 & 47,46 & 37,84 & 34,82 & 31,59 & 100,29 & 49,22 \\
\hline SET_05 & 2,66 & 9,02 & 3,72 & 9,95 & 3,23 & 7,96 & 1,83 & 51,92 & 1,20 \\
\hline NOV_05 & 3,92 & 5,31 & $1.020,98$ & 136,65 & $1.148,60$ & 145,06 & 24,47 & 23,60 & 22,47 \\
\hline MAR_06 & 12,18 & 15,02 & 17,98 & 27,34 & 10,47 & 15,81 & 8,98 & 728,89 & 44,41 \\
\hline ABR_06 & 4,96 & 15,02 & 33,11 & 111,38 & 19,13 & 92,87 & 46,01 & 82,88 & 35,73 \\
\hline MAI_06 & 5,74 & 14,16 & 40,15 & 69,57 & 20,64 & 48,63 & 29,47 & 28,82 & 29,14 \\
\hline JUN_06 & 6,42 & 19,42 & 4,56 & 2,07 & 3,47 & 1,22 & 1,87 & 55,40 & 2,55 \\
\hline JUL_06 & 4,39 & 17,57 & 8,67 & 32,60 & 8,72 & 23,64 & 7,93 & 68,46 & 7,76 \\
\hline AGO_06 & 0,92 & 24,49 & 16,77 & 35,45 & 14,39 & 25,09 & 0,11 & 16,55 & 0,06 \\
\hline SET_06 & 0,64 & 23,23 & 24,20 & 66,39 & 21,08 & 45,59 & 0,67 & 18,12 & 0,11 \\
\hline NOV 06 & 0,46 & 67,78 & 26,61 & 165,48 & 26,21 & 113,34 & 7,27 & 116,04 & 5,64 \\
\hline
\end{tabular}


Tabela 33 - Resultados da estatística de Lagrange para o dólar comercial

\begin{tabular}{|c|c|c|c|c|c|c|c|c|c|}
\hline Contratos & MLps & MLpf & MLvS & MLvf & MLrets & MLretf & MIress & MIresm6 & MIresm7 \\
\hline FEV_04 & 14,32 & 26,51 & 267,21 & $20.578,81$ & 207,98 & $23.250,10$ & 429,63 & $153.138,79$ & $2.088,70$ \\
\hline MAR_04 & 4,05 & 7,74 & 36,28 & 16,12 & 26,74 & 7,87 & 7,31 & 78,08 & 7,17 \\
\hline ABR_04 & 5,73 & 11,85 & 41,01 & 22,38 & 30,04 & 10,79 & 7,30 & 97,44 & 6,78 \\
\hline MAl_04 & 6,97 & 16,48 & 60,30 & 27,04 & 44,61 & 11,92 & 12,06 & 30,29 & 15,24 \\
\hline JUN_04 & 78,05 & 9,64 & 81,44 & 30,00 & 59,99 & 24,84 & 2,69 & 91,03 & 2,49 \\
\hline JUL_04 & 54,26 & 15,24 & 117,45 & 58,46 & 88,42 & 53,00 & 24,23 & 12,66 & 33,25 \\
\hline AGO_04 & 28,82 & 35,12 & 136,07 & 62,81 & 107,03 & 53,34 & 33,29 & 20,56 & 52,49 \\
\hline SET_04 & 18,88 & 5,07 & 144,06 & 95,18 & 113,12 & 77,37 & 64,91 & 153,95 & 165,82 \\
\hline OUT_04 & 35,31 & 1,37 & 212,73 & 95,54 & 161,45 & 83,14 & 67,13 & 322,14 & 148,97 \\
\hline NOV_04 & 27,05 & 13,85 & 153,04 & 105,57 & 115,80 & 78,45 & 79,70 & 121,82 & 199,24 \\
\hline DEZ_04 & 12,68 & 22,50 & 171,25 & 117,34 & 125,56 & 81,02 & 91,62 & 142,86 & 234,72 \\
\hline JAN_05 & 3,22 & 23,30 & 157,25 & 111,03 & 109,87 & 65,91 & 98,08 & 211,28 & 242,58 \\
\hline FEV_05 & 12,32 & 11,88 & 76,84 & 147,70 & 43,78 & 69,37 & 85,29 & $6.337,08$ & 241,45 \\
\hline MAR_05 & 7,48 & 16,30 & 136,76 & 123,91 & 80,78 & 61,24 & 91,11 & 56,93 & 227,63 \\
\hline ABR_05 & 13,90 & 17,63 & 78,01 & 77,64 & 45,72 & 34,49 & 49,99 & 43,00 & 87,46 \\
\hline MAI_05 & 3,08 & 5,34 & $16.939,43$ & $39.467,69$ & $11.681,62$ & $25.704,40$ & 0,50 & 150,05 & 0,38 \\
\hline JUN_05 & 4,37 & 7,62 & 2,22 & 5,27 & 1,99 & 6,09 & 3,03 & 192,34 & 1,76 \\
\hline JUL_05 & 9,95 & 9,10 & 10,28 & 8,10 & 13,78 & 8,60 & 11,07 & 50,08 & 9,46 \\
\hline AGO_05 & 9,55 & 11,14 & 20,29 & 11,97 & 28,47 & 20,10 & 16,41 & 209,74 & 13,28 \\
\hline SET_05 & 15,03 & 13,50 & 25,28 & 14,10 & 36,66 & 28,50 & 23,32 & 4,17 & 19,90 \\
\hline OUT_05 & 17,40 & 15,71 & 31,34 & 15,09 & 46,15 & 29,62 & 31,60 & 91,72 & 33,19 \\
\hline NOV_05 & 20,12 & 18,16 & 31,05 & 13,73 & 39,91 & 23,22 & 32,40 & 4,07 & 35,03 \\
\hline DEZ_05 & 20,69 & 19,59 & 28,26 & 16,42 & 34,86 & 26,20 & 31,97 & 35,13 & 35,84 \\
\hline JAN_06 & 22,71 & 21,47 & 26,87 & 13,02 & 34,03 & 21,56 & 30,00 & 0,63 & 31,17 \\
\hline FEV_06 & 21,38 & 21,28 & 18,72 & 14,07 & 19,88 & 14,43 & 32,90 & 56,80 & 40,42 \\
\hline MAR_06 & 23,23 & 18,25 & 20,58 & 17,52 & 20,16 & 16,60 & 33,94 & 57,55 & 39,43 \\
\hline ABR_06 & 24,39 & 19,33 & 21,99 & 17,73 & 21,86 & 15,63 & 36,86 & 50,18 & 44,41 \\
\hline MAl_06 & 8,17 & 10,06 & 29,00 & 30,04 & 23,82 & 19,73 & 58,36 & 72,10 & 96,22 \\
\hline JUN_06 & 7,33 & 11,06 & 199,99 & 94,10 & 187,97 & 105,37 & 51,77 & 68,09 & 78,30 \\
\hline JUL_06 & 7,47 & 16,45 & 209,91 & 87,40 & 198,71 & 99,11 & 49,82 & 67,13 & 78,06 \\
\hline AGO_06 & 2,12 & 15,10 & 271,18 & 137,55 & 229,54 & 121,63 & 24,52 & 82,12 & 36,83 \\
\hline SET_06 & 3,56 & 18,29 & 362,04 & 192,91 & 305,32 & 168,70 & 33,45 & 73,13 & 57,88 \\
\hline OUT_06 & 32,51 & 32,82 & 372,91 & 156,64 & 359,63 & 181,90 & 77,13 & 134,00 & 135,04 \\
\hline NOV_06 & 18,22 & 21,21 & 462,17 & 276,42 & 383,23 & 219,80 & 55,18 & 95,78 & 122,81 \\
\hline DEZ 06 & 26,33 & 37,46 & 594,31 & 368,47 & 495,17 & 283,93 & 65,57 & 77,52 & 160,98 \\
\hline
\end{tabular}

Tabela 34 - Resultados da estatística de Lagrange para o Ibovespa

\begin{tabular}{|c|c|c|c|c|c|c|c|c|c|}
\hline Contratos & MLps & MLpf & MLvs & MLvf & MLrets & MLretf & MIress & MIresm6 & MIresm7 \\
\hline FEV_04 & 5,92 & 4,97 & 23,58 & 21,79 & 6,92 & 8,42 & 386,73 & 55,12 & $3.433,69$ \\
\hline ABR_04 & 3,35 & 5,25 & 2,39 & 1,67 & 1,99 & 1,30 & 571,50 & $280.416,79$ & $5.537,81$ \\
\hline JUN_04 & 16,57 & 10,14 & 33,57 & 20,01 & 13,07 & 8,04 & $1.206,39$ & $8.088,76$ & $12.992,75$ \\
\hline AGO_04 & 8,76 & 3,49 & 9,12 & 5,96 & 6,50 & 3,57 & 912,49 & 160,50 & $8.718,22$ \\
\hline OUT_04 & 12,25 & 0,18 & 12,78 & 7,80 & 11,07 & 4,49 & $1.308,59$ & 557,22 & $14.434,21$ \\
\hline DEZ_04 & 4,37 & 4,20 & 7,99 & 7,64 & 9,66 & 4,81 & $7.462,51$ & 26,12 & $181.739,80$ \\
\hline FEV_05 & 3,25 & 0,72 & 0,62 & 4,10 & 0,39 & 3,24 & $13.629,22$ & $855.503,12$ & $532.612,66$ \\
\hline ABR_05 & 2,71 & 1,89 & 128,30 & 0,50 & 107,51 & 0,37 & $3.098,45$ & $2.829 .873,77$ & $95.838,84$ \\
\hline JUN_05 & 6,40 & 33,68 & 225,93 & 0,70 & 116,15 & 1,10 & $25.808,74$ & $195.609,97$ & $1.317 .785,92$ \\
\hline AGO_05 & 3,91 & 29,91 & 200,71 & 0,21 & 121,69 & 0,46 & $28.371,36$ & $141.654,07$ & $1.472 .611,93$ \\
\hline OUT_05 & 5,04 & 4,82 & 4,19 & 1,94 & 3,68 & 1,69 & 0,21 & $1.039,79$ & 0,05 \\
\hline DEZ_05 & 20,88 & 14,38 & 92,57 & 1,34 & 91,80 & 1,60 & $34.415,47$ & $6.236,07$ & $1.953 .553,38$ \\
\hline FEV_06 & 20,82 & 20,82 & 79,49 & 1,69 & 119,04 & 1,97 & $26.794,45$ & 513,40 & $1.336 .479,99$ \\
\hline ABR 06 & 14,23 & 12,76 & 3,73 & 6,57 & 4,71 & 9,93 & 30,70 & 98,61 & 49,22 \\
\hline JUN 06 & 7,04 & 6,94 & 17,37 & 2,24 & 25,23 & 3,34 & $1.387,60$ & 100,64 & $14.090,18$ \\
\hline AGO 06 & 1,54 & 5,05 & 2,60 & 4,28 & 5,38 & 6,43 & 821,70 & $220.652,99$ & $7.305,57$ \\
\hline OUT_06 & 12,98 & 59,34 & 6,11 & 3,19 & 9,89 & 3,64 & $1.286,90$ & 62,32 & $17.212,34$ \\
\hline DEZ 06 & 6,39 & 7,57 & 11,91 & 1,78 & 24,21 & 3,17 & $1.254,56$ & 90,55 & $14.098,25$ \\
\hline
\end{tabular}

